\title{
ANAEROBIC DEGRADATION OF DIESEL FUEL CONTAMINATED WASTEWATER IN A FLUIDIZED BED RECTOR
}

\author{
by \\ Jonka Vezuli \\ (Bachelor of Science, University of Tirana, Tirana, 1996)
}

\author{
A Thesis \\ presented to Ryerson University \\ in partial fulfillment of the \\ requirements for the degree of \\ Master of Applied Science \\ in the Program of \\ Chemical Engineering
}

Toronto, Ontario, Canada, 2004

C Jonka Vezuli 
UMI Number: EC53421

\section{INFORMATION TO USERS}

The quality of this reproduction is dependent upon the quality of the copy submitted. Broken or indistinct print, colored or poor quality illustrations and photographs, print bleed-through, substandard margins, and improper alignment can adversely affect reproduction.

In the unlikely event that the author did not send a complete manuscript and there are missing pages, these will be noted. Also, if unauthorized copyright material had to be removed, a note will indicate the deletion.

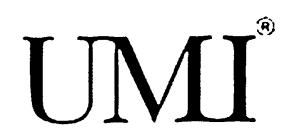

UMI Microform EC53421

Copyright 2009 by ProQuest LLC

All rights reserved. This microform edition is protected against unauthorized copying under Title 17, United States Code.

ProQuest LLC

789 East Eisenhower Parkway

P.O. Box 1346

Ann Arbor, MI 48106-1346 


\section{Author's Declaration Page}

I hereby declare that I am the sole author of this thesis.

I authorize Ryerson University to lend this thesis to other institutions or individuals for the purpose of scholarly research.

Signature

\section{V}

Jonka Vezuli

I further authorize Ryerson University to reproduce this thesis by photocopying or by other means, in total or in part, at the request of other institutions or individuals for the purpose of scholarly research.

Signature

Jonka Vezuli 


\section{BORROWER'S PAGE}

Ryerson University requires the signatures of all persons using this thesis. Please sign below, and give address and date. 


\begin{abstract}
ANAEROBIC DEGRADATION OF DIESEL FUEL CONTAMINATED

WASTEWATER IN A FLUIDIZED BED RECTOR
\end{abstract}

Jonka Vezuli, 2004,

Master of Applied Science,

Chemical Engineering Department, Ryerson University

This thesis studies the performance of the Anaerobic Fluidized Bed Reactor (AFBR) in treating diesel fuel-contaminated wastewaters. (The AFBR is a semi-cylindrical fluidized bed, with a capacity of $300 \mathrm{~L}$ and height of $2.90 \mathrm{~m}$ with sampling ports along the column length. Granular activated carbon (12-20 mesh) was used as the medium to immobilize biomass. Diesel fuel was the sole source of carbon for microorganisms. The system's COD removal capability and diesel fuel removal efficiency were measured at $100 \mathrm{mg} / \mathrm{L}$, $200 \mathrm{mg} / \mathrm{L}$, and $300 \mathrm{mg} / \mathrm{L}$ influent diesel fuel in the reactor). (Hydraulic Residence Time (HRT) varied for each set of experiments from 96 to 6 hours) (The system achieved diesel removal efficiency of more than $84.1 \%$ for $300 \mathrm{mg} / \mathrm{L}$ influent diesel concentration for the maximum flowrate treated $(1200 \mathrm{~L} / \mathrm{d})$ at a minimum HRT of 6 hours. This investigation confirms that anaerobic degradation of diesel-contaminated water can be carried out very effectively in the AFBR. 


\section{ACKNOWLEDGEMENT}

I would like to express my appreciation to my major supervisor, Dr. Manuel Alvarez Cuenca, who provided remarkable assistance and support throughout this project, and over the course of the master program. Dr. Cuenca is an unusual individual who is able to lead without controlling, to inspire without pontificating, and to relate to those less educated and experienced without condescension. His frankness and openness have made it a pleasure to have him serve as major supervisor.

I would like to thank and acknowledge Dr. Ali Lohi for his assistance throughout the master program. It would not have been possible to embark on this project, nor to sustain the effort required completing it, without the love and support of my family. They have provided great support and I can only hope to live up to their expectations. 


\section{TABLE OF CONTENTS}

DESCRIPTION

PAGE

Title Page

Author's Declaration

ii

Borrower's Page

Abstract

iv

Acknowledgements

V

Table of Contents

vi

List of Tables

$\mathrm{X}$

List of Figures

xii

Nomenclature

xvii

CHAPTER 1. GENERAL INTRODUCTION 1

1.1. Introduction $\quad 1$

1.2. Objectives and Scope of the Thesis 3

CHAPTER 2. REVIEW OF EXISTING LITERATURE 4

2.1. Diesel Fuel $\quad 4$

2.2. Diesel Fuel in Groundwater 6

$\begin{array}{ll}\text { 2.3. Anaerobic Fluidized Bed Reactor } & 7\end{array}$

2.3.1. Advantages of Anaerobic Fluidized Bed Reactor $\quad 8$

2.3.2. Disadvantages of Anaerobic Fluidized Bed Reactor $\quad 10$

$\begin{array}{lr}\text { 2.3.3. Principles of Fluidization } & 10\end{array}$

$\begin{array}{ll}\text { A. Minimum Fluidization Velocity } & 11\end{array}$

$\begin{array}{ll}\text { B. Terminal Velocity } & 12\end{array}$ 
C. Recycle Ratio

2.4. Economics on A Comparative Evaluation of Aerobic and Anaerobic

Biodegradation Processes

2.5. Anaerobic Biological Treatment

2.5.1. Effect of Temperature

2.5.2. Effect of $\mathrm{pH}$

2.5.3. Effect of Nutrients

2.6. GAC as an Attachment Medium

CHAPTER 3. EXPERIMENTAL METHODS

3.1. Experimental Facility

$\begin{array}{ll}\text { A. Vacuum Stripper } & 20\end{array}$

B. Feed Tank and Synthetic Wastewater 22

C. Anaerobic Fluidized Bed Reactor 25

$\begin{array}{ll}\text { D. Flow Distributor } & 26\end{array}$

$\begin{array}{ll}\text { E. Inoculation and Operation of AFBR } & 27\end{array}$

F. Sampling Ports $\quad 32$

$\begin{array}{ll}\text { G. Reactor Media } & 33\end{array}$

3.2. Analytical Methods $\quad 35$

$\begin{array}{ll}\text { A. } \mathrm{pH} & 35\end{array}$

B. Chemical Oxygen Demand 36

$\begin{array}{ll}\text { C. Raman White Light Microscopy } & 37\end{array}$

D. Liquid-Liquid Extraction $\quad 38$

$\begin{array}{ll}\text { E. Internal Standard } & 39\end{array}$ 
F. Gas Chromatography/Mass Spectrometry 39

G. Calibration Curve for GC-MS 42

H. Dissolved Oxygen Meter $\quad 44$

3.3. Typical Experimental Run 46

3.4. Experimental Program $\quad 48$

$\begin{array}{lr}\text { 3.4.1. Phase I } & 49\end{array}$

$\begin{array}{lr}\text { 3.4.2. Phase II } & 50\end{array}$

3.4.3. Phase III $\quad 51$

3.4.4. Phase IV 52

CHAPTER 4. RESULTS AND DISCUSSION 53

4.1. Evaluations of Gas Chromatogram Results 53

4.2. Dissolved Oxygen Measurements $\quad 61$

4.3. Evaluation of Chemical Oxygen Demand Results 64

4.4. Adsorption of Diesel Fuel on GAC 71

4.4.1.Introduction $\quad 71$

4.4.2. Experimental Procedure $\quad 72$

$\begin{array}{ll}\text { 4.5. Biofilm Thickness } & 77\end{array}$

CHAPTER 5. CONCLUSIONS AND RECOMMENDATIONS 79

5.1. Conclusions $\quad-\quad 80$

$\begin{array}{ll}\text { 5.2. Recommendations } & 81\end{array}$

REFERENCES 282

APPENDIX A - Sample Calculations $\quad 89$

APPENDIX B - Chemical Oxygen Demand $\quad 92$ 
APPENDIX C - Gas Chromatograms for Calibration Curve 96

APPENDIX D - Gas Chromatogram Values for Experimental Runs 110

APPENDIX E - Gas Chromatograms for the Anaerobic Adsorption Test 112 


\section{LIST OF TABLES}

DESCRIPTION

PAGE

Table 1 Composition of Diesel Fuel 5

$\begin{array}{lll}\text { Table } 2 \text { Diesel Fuel Degrading Microorganisms } & 17\end{array}$

Table 3 Nutrients used for anaerobic diesel fuel degrading microorganisms 23

Table 4 Diesel fuel Concentrations in the Feed Tank during each

$\begin{array}{ll}\text { Experimental Run } & 24\end{array}$

Table 5 Operating Conditions for Anaerobic Fluidized Bed Reactor 29

Table 6 Physical Properties of GAC Media Used in this Study 35

$\begin{array}{lll}\text { Table } 7 & \text { GC-MS Instrumental Conditions } & 41\end{array}$

Table 8 Values for Gas Chromatogram Calibration Curve for Diesel Fuel

Standards

Table 9 Operating Parameters for the Anaerobic Fluidized Bed Reactor during Phase I.

Table 10 Operating Parameters for the Anaerobic Fluidized Bed Reactor during Phase II

Table 11 Operating Parameters for the Anaerobic Fluidized Bed Reactor during Phase III

Table 12 Operating Parameters for the Anaerobic Fluidized Bed Reactor during Phase IV 
Table 13 Dissolved Oxygen Profile at the Inlet and the Outlet of Vacuum

Stripper

Table 14 Experimental Data for the Anaerobic Adsorption Isotherm Test

Table 15 Calculated Values for the Anaerobic Adsorption Isotherm Test

Table B 1 Chemical Oxygen Demand Results-Phase I

Table B 2 Chemical Oxygen Demand Results-Phase II

Table B 3 Chemical Oxygen Demand Results-Phase III

Table B 4 Chemical Oxygen Demand Results-Phase IV

Table D 1 Gas Chromatogram Values for Experimental Runs, Phase I and Phase II

Table D 2 Gas Chromatogram Values for Experimental Runs, Phase III and Phase IV 


\section{LIST OF FIGURES}

DESCRIPTION

PAGE

$\begin{array}{lll}\text { Figure } 1 & \text { Schematic Diagram of Vacuum Stripper }\end{array}$

Figure 2 Schematic Diagram of Anaerobic Fluidized Bed Reactor 25

$\begin{array}{lll}\text { Figure } 3 & \text { Flow Distributor Diagram } & 26\end{array}$

Figure 4 Process Flow Diagram of the Anaerobic Fluidized Bed Reactor 28

Figure 5 Sampling Ports in the Anaerobic Fluidized Bed Reactor 32

Figure 6 Media Types A) Lava Rock; B) Granular Activated Carbon;

C) Cork-Metal; D) Tri-pack;

Figure 7 Chemical Oxygen Demand Analysis- Closed Reflux

Figure 8 Diagram of Liquid-Liquid Extraction

Figure 9 The structure of Internal Standard, $5 \alpha$ Androstane 39

$\begin{array}{lll}\text { Figure } 10 & \text { Diagram of a GC-MS combination } & 40\end{array}$

Figure 11 Diesel Fuel Calibration Curve 44

Figure 12 Dissolved Oxygen Measurement Equipment 45

Figure 13 Schematic Diagram of the Experimental Facility 46

Figure 14 Diesel Fuel Concentration Measured by GC-MS at Various

Points, Phase I

Figure 15 Diesel Fuel Concentration Measured by GC-MS at Various

Points, Phase II

Figure 16 Diesel Fuel Concentration Measured by GC-MS at Various

Points, Phase III 
Figure 17 Diesel Removal Efficiency Profile for Phase I, Phase II and Phase III

Figure 18 Diesel Fuel Concentration Measured by GC-MS at Various Points, Phase IV

Figure 19 Diesel Removal Efficiency Profile for Phase I and Phase IV

Figure 20 The Dissolved Oxygen Profile at Various Points in the

Experimental System

Figure 21 COD Concentrations and COD Removal Percentage at Various Points in the AFBR, Phase I

Figure 22 COD Concentrations and COD Removal Percentage at Various

Points in the AFBR, Phase II

Figure 23 COD Concentrations and COD Removal Percentage at Various Points in the AFBR, Phase III

Figure 24 COD Removal Capability for Phase I, Phase II and Phase III

Figure 25 COD Concentrations and COD Removal Percentage at Various Points in the AFBR, Phase IV

Figure 26 COD Removal Capability for Phase I and Phase IV

Figure 27 Variation of the COD Loading Rate as a function of the COD Removal Efficiency

Figure $28 \log (\mathrm{x} / \mathrm{m})$ Vs. Log Ce for Determination of $\mathrm{K}$ and $\mathrm{n}$ Constants

Figure 29 Adsorption Isotherm of Diesel Fuel onto GAC

Figure 30 White Light (microscope) Image of Stages in Biofilm Formation on the Surface of a GAC Particle A) Clean particle; B) Biofilm attachment initially in the crevices of GAC particle; C) Fully developed biofilm; 
Figure C 1 Gas Chromatogram-Standard 25 ppm Diesel Trial 1

Figure C 2 Gas Chromatogram -Standard 25 ppm Diesel Trial $2 \quad 96$

Figure C 3 Gas Chromatogram -Standard 50 ppm Diesel Trial 1

Figure C 4 Gas Chromatogram -Standard 50 ppm Diesel Trial 2

Figure C 5 Gas Chromatogram -Standard 100ppm Diesel Trial $1 \quad 98$

Figure C 6 Gas Chromatogram -Standard 100ppm Diesel Trial $2 \quad 98$

Figure C 7 Gas Chromatogram -Standard 200ppm Diesel Trial 1

Figure C 8 Gas Chromatogram -Standard 200ppm Diesel Trial $2 \quad 99$

Figure C 9 Gas Chromatogram -Standard 250ppm Diesel Trial 1 100

Figure C 10 Gas Chromatogram -Standard 250ppm Diesel Trial 2 100

Figure C 11 Gas Chromatogram -Standard 300ppm Diesel Trial 1

Figure C 12 Gas Chromatogram -Standard 300ppm Diesel Trial 2

Figure C 13 Gas Chromatogram -Standard 400ppm Diesel Trial 1

Figure C 14 Gas Chromatogram -Standard 400ppm Diesel Trial 2

Figure C 15 Gas Chromatogram - Diesel Extracted Standard 25ppm Trial 1103

Figure C 16 Gas Chromatogram - Diesel Extracted Standard 25ppm Trial 2103

Figure C 17 Gas Chromatogram -Standard 50ppm Diesel Extracted Trial $1 \quad 104$

Figure C 18 Gas Chromatogram - Diesel Extracted Standard 50ppm Trial 2104

Figure C 19 Gas Chromatogram - Diesel Extracted Standard 100ppm Trial 1105

Figure C 20 Gas Chromatogram - Diesel Extracted Standard 100ppm Trial 2105

Figure C 21 Gas Chromatogram - Diesel Extracted Standard 200ppm Trial 1 106,

Figure C 22 Gas Chromatogram - Diesel Extracted Standard 200ppm Trial 2106

Figure C 23 Gas Chromatogram - Diesel Extracted Standard 250ppm Trial 1107 
Figure C 24 Gas Chromatogram - Diesel Extracted Standard 250ppm Trial 2107

Figure C 25 Gas Chromatogram - Diesel Extracted Standard 300ppm Trial 1108

Figure C 26 Gas Chromatogram - Diesel Extracted Standard 300ppm Trial 2108

Figure C 27 Gas Chromatogram - Diesel Extracted Standard 400ppm Trial 1109

Figure C 28 Gas Chromatogram - Diesel Extracted Standard 400ppm Trial 2109

Figure E 1 Gas Chromatogram - Experimental Run 1 Anaerobic Adsorption Isotherm Test, Trial 1

Figure E 2 Gas Chromatogram - Experimental Run 1 Anaerobic Adsorption Isotherm Test, Trial 2

Figure E 3 Gas Chromatogram - Experimental Run 2 Anaerobic Adsorption Isotherm Test, Trial 1

Figure E 4 Gas Chromatogram - Experimental Run 2 Anaerobic Adsorption Isotherm Test, Trial 2

Figure E 5 Gas Chromatogram - Experimental Run 3 Anaerobic Adsorption Isotherm Test, Trial 1

Figure E 6 Gas Chromatogram - Experimental Run 3 Anaerobic Adsorption Isotherm Test, Trial 2

Figure E 7 Gas Chromatogram - Experimental Run 4 Anaerobic Adsorption Isotherm Test, Trial 1

Figure E 8 Gas Chromatogram - Experimental Run 4 Anaerobic Adsorption Isotherm Test, Trial 2

Figure E 9 Gas Chromatogram - Experimental Run 5 Anaerobic Adsorption Isotherm Test, Trial 1 
Figure E 10 Gas Chromatogram - Experimental Run 5 Anaerobic Adsorption Isotherm Test, Trial 2

Figure E 11 Gas Chromatogram - Experimental Run 6 Anaerobic Adsorption Isotherm Test, Trial 1

Figure E 12 Gas Chromatogram - Experimental Run 6 Anaerobic Adsorption Isotherm Test, Trial 2

Figure E 13 Gas Chromatogram - Experimental Run 7 Anaerobic Adsorption Isotherm Tèst, Trial 1

Figure E 14 Gas Chromatogram - Experimental Run 7 Anaerobic Adsorption Isotherm Test, Trial 2

Figure E 15 Gas Chromatogram - Experimental Run 8 Anaerobic Adsorption Isotherm Test, Trial 1

Figure E 16 Gas Chromatogram - Experimental Run 5 Anaerobic Adsorption Isotherm Test, Trial 8 


\section{Nomenclature}

\section{List of Symbols}

A $\quad\left(\mathrm{m}^{2}\right) \quad$ Cross Sectional Area of Column

$A_{p} \quad\left(m^{2}\right) \quad$ Cross Sectional Area of the Particle

Ar (-) $\quad$ Archimedes Number

$\mathrm{C}_{\mathrm{D}} \quad(-) \quad$ Drag Coefficient

$\mathrm{D}_{\mathrm{c}} \quad(\mathrm{m}) \quad$ Column Diameter.

$\mathrm{D}_{\mathrm{H}} \quad(\mathrm{m}) \quad$ Hydraulic Diameter of the Column

$\mathrm{d}_{\mathrm{p}} \quad(\mathrm{m}) \quad$ Particle Diameter

$F_{B} \quad\left(\mathrm{~kg} \cdot \mathrm{m} / \mathrm{s}^{2}\right) \quad$ Buoyancy Force

$\mathrm{F}_{\mathrm{D}} \quad\left(\mathrm{kg} \cdot \mathrm{m} / \mathrm{s}^{2}\right) \quad$ Drag Force

$\mathrm{F}_{\mathrm{G}} \quad\left(\mathrm{kg} \cdot \mathrm{m} / \mathrm{s}^{2}\right) \quad$ Gravitational Force

g $\left(\mathrm{m} / \mathrm{s}^{2}\right) \quad$ Acceleration due to Gravity

$\mathrm{H}_{\mathrm{f}} \quad$ - (m) $\quad$ Fluidized Bed Height

$\mathrm{H}_{\mathrm{o}} \quad$ (m) Initial Bed Height

\begin{tabular}{lll}
\hline $\mathrm{Q}$ & $\left(\mathrm{m}^{3} / \mathrm{d}\right)$ & Flow Rate \\
\hline $\mathrm{Q}$ & $\left(\mathrm{m}^{3} / \mathrm{d}\right)$ & Flowrate \\
$\mathrm{R}$ & $(-)$ & Recycle Ratio \\
$\mathrm{R}_{\mathrm{c}}$ & $(\mathrm{m})$ & Radius of Column \\
$\mathrm{Re}$ & $(-)$ & Reynolds Number \\
$\operatorname{Re}$ & $(-)$ & Reynolds Number \\
$\mathrm{R}_{\mathrm{H}}$ & $(\mathrm{m})$ & Hydraulic Radius of the Column \\
$\mathrm{r}_{\mathrm{p}}$ & $(\mathrm{m})$ & Radius of the Particle
\end{tabular}




$\begin{array}{lll}\text { S } & \left(\mathrm{kg} / \mathrm{m}^{3}\right) & \text { Chemical Oxygen Demand Concentration } \\ \text { U } & (\mathrm{m} / \mathrm{s}) & \text { Liquid Superficial Velocity } \\ \text { V } & \left(\mathrm{m}^{3}\right) & \text { Volume } \\ \text { W } & (\mathrm{kg}) & \text { Mass }\end{array}$

Greek Symbols

$\tau \quad\left(\right.$ dyne $\left./ \mathrm{cm}^{2}\right) \quad$ Shear Stress

$\varepsilon \quad(-) \quad$ Porosity of Bed

$\mu \quad\left(\mathrm{Ns} / \mathrm{m}^{2}\right) \quad$ Viscosity

$\rho \quad\left(\mathrm{kg} / \mathrm{m}^{3}\right) \quad$ Density

$\sigma \quad(\mu \mathrm{m}) \quad$ Biofilm Thickness

$\Phi \quad(-) \quad$ Sphericity

Subscripts

$\begin{array}{lll}\text { b } & (-) & \text { Bioparticle } \\ \text { bf } & (-) & \text { Biofilm } \\ \text { e } & (-) & \text { Effluent } \\ \text { i } & (-) & \text { Influent } \\ \text { l } & (-) & \text { Liquid } \\ \text { mf } & (-) & \text { Minimum Fluidization } \\ \text { o } & (-) & \text { Feed } \\ \text { p } & (-) & \text { Particle } \\ \text { r } & (-) & \text { Recycle } \\ \text { s } & (-) & \text { Solid } \\ \text { t } & (-) & \text { Terminal }\end{array}$




\section{CHAPTER 1. GENERAL INTRODUCTION}

\subsection{Introduction}

Diesel fuel hydrocarbons are considered common environmental pollutants, which have the potential to contaminate large quantities of groundwater (Van Stempvoort et al. 2000). Many diesel spills in groundwater reported by Environment Canada (1994) like those on: Nov. 26, 1992 in Northern Quebec; Sept. 23, 1993, in Laurel, NS; Mar. 7, 1994, in Ashechewan Bay, ON; etc, are all indication of a constant environmental contamination problem in Canada. Certain aromatic hydrocarbons common in diesel fuel such as benzene, ethylbenzene, toluene, and xylene are toxic, hazardous and carcinogenic chemicals to human health as stated in Health and Welfare Canada, (1989). In addition, polycyclic aromatic hydrocarbons $(\mathrm{PAH})$ including benzo(a)pyrene, benz(a)anthracene, benzo(b)fluoranthene, benzo(k)fluoranthene, $\operatorname{dibenz}(\mathrm{a}, \mathrm{h})$ anthracene, indeno[1,2,3]pyrene and chrysene are carcinogenic to human health as pointed out by Agency for Toxic Substances and Disease Registry (ATSDR, 1990). There are two main potential sources of environmental pollution with diesel fuel according to Erickson, (2000): a) Continuous low-level inputs from roads surfaces and domestic waste; b) Major spillage from tankers, pipelines, and storage tanks. Initially accidental diesel spillage, for example, caused from customers at the service station contaminates the soil. Diesel fuel being a persistent chemical increases the chance for groundwater contamination. For aboveground diesel spills rainwater delivers diesel into sewage systems or large bodies of water. Rainwater acts as a carrier of the diesel fuel. While for diesel spills occurring deeper into the ground it contaminates aquifers used for drinking water (Perryman, 2003). 
Microbial degradation occurs in nature reducing hydrocarbons in the soil and water over very long periods of time.

Today the need for water has increased so much that naturally occurring biodegradative process to clean up contaminated groundwater is no longer sufficient. Advances in technology have made it easier to intensify and accelerate the process of diesel fuel degradation through bioremediation. The size of treatment process when treating wastewater can be reduced using high concentrations of bacteria. The use of attached growth is a means of obtaining very high concentration of bacteria. Fluidized bed reactors, among the attached growth processes, provide a dual advantage: they prevent clogging problems found in fixed beds, and they promote rapid transfer of material between the liquid and the biomass (Trinet et al. 1991). Aerobic microbial degradation of diesel fuel hydrocarbons has been recognized and understood for a long time as shown in the study done by Rehm and Reiff, (1981). Aerobic biodegradation processes, while found to be effective in treating diesel fuel contamination, are often quite expensive when relying on oxygen carriers as observed by Boopathy (2003). Bouwer, (1992) concluded that the anaerobic conditions often prevail in contaminated groundwater because the $\mathrm{O}_{2}$ demand exceeds the $\mathrm{O}_{2}$ supply. This thesis focuses on bioremediation of diesel-contaminated water using an Anaerobic Fluidized Bed Reactor. 


\subsection{Objectives and Scope of the Thesis}

A study was conducted at the Laboratory of Water and Wastewater Treatment and Technologies (LWWTT) to determine the feasibility of using the anaerobic fluidized bed reactor for the biodegradation of diesel fuel-contaminated wastewater. Diesel fuel is on the Environmental Protection Agency (EPA)'s pollutant priority list (Erickson, 2000). Aerobic degradation process was studied previously in the LWWTT using RBC and Three Phase Fluidized Bed Reactor. These studies found that the aerobic process is effective in treating diesel contamination although often quite expensive when relying on oxygen carriers. Anaerobic degradation is desirable because much of the contaminated groundwater is already at anaerobic conditions. The Anaerobic Fluidized Bed Reactor during this project was operated in a continuous-flow mode.

The focal point of this thesis was to determine the feasibility of the anaerobic . microorganisms to biodegrade diesel fuel in wastewater using the fluidized bed reactor. Diesel fuel concentration at influent, midpoint and effluent sampling ports in the reactor was determined using gas chromatographic/mass spectroscopic methods.

The effect of operational conditions such as organic loading rate (OLR), hydraulic residence time (HRT) and influent diesel concentration was investigated to achieve the maximum diesel removal efficiency of the reactor. 


\section{CHAPTER 2. REVIEW OF EXISTING LITERATURE}

\subsection{Diesel Fuel}

Diesel fuel is a complex mixture of hydrocarbons used for diesel engines (Blumer, 1976). Hydrocarbons are organic chemical compounds that consist of only carbon (C) and hydrogen (H) atoms (ILPI, 2004). Diesel fuels consist mainly of saturate (paraffins and naphthenes) and aromatic hydrocarbons. Their relative distribution depends on the feedstocks and fuel processing schemes (Song et al. 2000). It should be noted that oil companies, through their refineries, generally vary the mix of hydrocarbons in the fuels they supply to suit the demand, climate and the season of the year. They include more components with low boiling point ranges in cold climates and in winter, and vice versa in hot weather; the composition of diesel fuels can therefore be significantly different (Garrett, 1991). Diesel fuel is a blend of high-molecular-weight fractions of crude oil that come off in distillation after gasoline. Diesel fuel composition varies greatly and includes mostly $C_{9}$ to $C_{20}$ hydrocarbons with a boiling point range of about 160 to $380^{\circ} \mathrm{C}$ (Huang et al. 1989). Molecular components of diesel fuel are listed in Table 1.

Saturated Hydrocarbons are dominant diesel components that include normal paraffins (n-paraffins), isoparaffins, and cycloparaffins (naphthenes). Usually long chain alkanes with carbon numbers in the range of $\mathrm{C}_{9}-\mathrm{C}_{20}$ are the major paraffinic components. Alkylcyclohexanes, decahydronaphthalenes and perhydrophenanthrenes are typical examples of 1-ring to 3-ring cycloalkanes in diesel fuels (Song et al. 2000). 


\begin{tabular}{|c|c|c|c|c|}
\hline Fuel & $\begin{array}{l}\text { Distillate } \\
\text { Fraction }\end{array}$ & $\begin{array}{c}\text { Boiling Range, } \\
\%_{C}\end{array}$ & Components & Mass \\
\hline \multirow{9}{*}{ Diesel } & \multirow{9}{*}{ Light Gas Oil } & \multirow{5}{*}{ 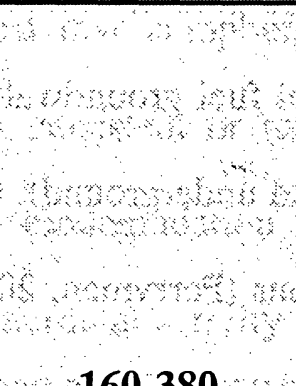 } & Paraffins & 39.7 \\
\hline & & & Cycloparaffins & 50.8 \\
\hline & & & Alkyl Benzenes & \\
\hline & & & Indanes, Tetralins & 0.8 \\
\hline & & & N & ses \\
\hline & & & Indenes & 0.1 \\
\hline & & Whengon & Alkyl-Naphthalenes & 1.6 \\
\hline & & sos & Acenaphthenes, Biphenyls & 2.2 \\
\hline & & now & Acenaphthalenes, Fluorenes & 1.7 \\
\hline
\end{tabular}

Aromatic compounds in diesel fuels are mainly alkylated benzenes, indanes, naphthalenes, tetralins, biphenyls, acenaphthenes, phenanthrenes, anthracenes, and naphthenophenanthrenes. Diaromatic hydrocarbons with naphthalene-type structure are the most abundant aromatic components in diesel fuel (Huang et al. 1989). Trace amounts of polycyclic aromatic hydrocarbons with three or more ring aromatic compounds such as chrysenes, pyrenes, benzanthracenes, and perylenes can also be present in diesel fuel (Hsu, 2000). 


\subsection{Diesel Fuel in Groundwater}

Over eight million Canadians residing in urban and rural areas rely on groundwater for their domestic water supply (Environment Canada, 2004). Groundwater first becomes contaminated when diesel fuel hydrocarbons are partially dissolved or mixed in waters recharging the aquifer. Some examples of diesel fuel groundwater contamination are via pipeline and storage tanks leaks (both above and underground), tanker and rig accidents, and diesel spills during transfer at service stations (Perryman, 2003). To comprehend the question of why diesel fuel is so undesirable and unwanted in water we have to look in its properties and composition. Diesel fuel composition (as shown in Table 1) includes more than $90 \%$ saturated hydrocarbons (Paraffins and Cycloparaffins) and less than $10 \%$ aromatic hydrocarbons (Alkyl Benzenes, Indanes +Tetralins, Indenes, AlkylNaphthalenes, Acenaphthenes/Biphenyls, Acenaphthalenes/Fluorenes). Diesel fuel is on the Environmental Protection Agency's (EPA) priority pollutant list. The selection of priority pollutants is based upon toxicity to mammals and persistence of the compound (Eriksson, 2000). The Alberta Management of Underground Storage Tanks (MUST) Guidelines (Alberta MUST. 1990) should be referred to in the absence of Ontario Criteria (for Drinking Water/Aquatic Life) standards.

The MUST guidelines set the standards for TPH-diesel fuel levels in groundwater:

$$
\begin{aligned}
& <0.2 \mathrm{mg} / \mathrm{l} \text { (level I) in High Sensitivity Sites } \\
& <50.0 \mathrm{mg} / \mathrm{l} \text { (level II) in Moderate Sensitivity Sites } \\
& <200.0 \mathrm{mg} / \mathrm{l} \text { (level III) in Low Sensitivity Sites }
\end{aligned}
$$

Taking into consideration the cleanup standards for any carcinogenic (such as benzene, PAHs) and any hazardous (ethylbenzene, toluene, xylenes and naphthalenes) component 
of diesel fuel in groundwater is required. These groundwater cleanup standards should be met for example, a) Benzene has the Maximum Concentration Limit (MCL) of $5 \mathrm{ppb}$ (parts per billion); b) Xylene has the MCL of $10 \mathrm{ppm}$; c) Ethylbenzene has the MCL of $0.7 \mathrm{ppm}$; d) Toluene has the MCL of $1 \mathrm{ppm}$; e) Benzo (a) pyrene has the MCL of $0.2 \mathrm{ppb}$. Cookson (1995) indicated that compounds resistant to biodegradation under certain conditions are known as persistent or refractory. Diesel fuel is a refractory chemical regarded as resistant to biodegradation (Metcalf and Eddy, 2002). Some important conditions that support microbial activity include utilizing a suitable electron donor and choosing the proper microbial species. The diesel fuel degradation is also affected by the molecular composition of the hydrocarbons, a characteristic that is directly related to the bioavailability of these compounds, and as a consequence, the biodegradation rate may be altered (Huesemann, 1995).

\subsection{Anaerobic Fluidized Bed Reactor}

Anaerobic Fluidized Bed Reactors have been employed for the last three decades in the biotechnology industry and in the treatment of wastewater. The Anaerobic Fluidized Bed Reactor (AFBR) is a secondary biological wastewater treatment process. It combines the advantages of both conventional suspended-growth reactors and fixed-film reactors (Fox, 1989). The solid phase is formed by porous particles or support medium. This support medium consists of small particles that provide a large surface area for biofilm growth. The fluidized carriers or support media can be plastic beads, sand grains, granular activated carbon (GAC), lava rocks, or other small solids that are resistant to abrasion. The upward velocity called fluidizing velocity of the fluid must be sufficient to 
maintain the carriers in suspension and this depends upon the density of the carriers relative to that of water, the carrier diameter and shape, and the amount of biomass that is attached. Fluidized bed reactors have great surface area per unit reactor volume, which allows shorter Hydraulic Residence Time (HRT) for the same degree of treatment in a given volume (Vigneswaran et al. 1986). Biomass concentrations in Fluidized Bed Reactors are often one order of magnitude greater than biomass concentrations found in conventional suspended-growth reactors (Fox, 1989). A high concentration of biomass develops a thin biofilm on the solids that maximizes contact between substrate and biomass and minimizes mass transport limitations. The biofilm or slime layer adsorbs the organic material from the liquid. As the microorganisms grow the thickness of the slime layer increases. Biofilm thickness must be controlled to prevent washout of particles whose density will decrease due to attached biomass (Shieh et al. 1981). Yoda et al. (1987) reported that the growth rate of anaerobic microorganisms is very slow therefore the increase in biofilm thickness did not have a severe impact on the effective density of particles.

\section{3.1. Advantages of Anaerobic Fluidized Bed Reactor}

Anaerobic Fluidized Bed Reactor is applied in wastewater treatment because of its several advantages that derive directly or indirectly from the ability to provide high biomass concentrations and relatively high organic loadings (Metcalf and Eddy, 2002). The following are some of the most important advantages of AFB Reactors:

- Liquid like behaviour, easy to control and automate.

- Applicable for large or small scale operations. 
- Heat and mass transfer rates are high, requiring smaller surfaces (Metcalf and Eddy, 2002).

- Low hydraulic head loss combined with better hydraulic circulation.

- Easy removal or addition of particles.

- Ability to operate at low residence times and/or higher organic loading rates.

- Greater surface area available per unit of reactor volume.

- Elimination of bed clogging and channeling (Bigmami et al. 1991).

- A minimal biomass sloughing with the virtual absence of biomass washout (Bigmami et al. 1991).

Further, Cooper and Atkinson (1981) claimed the following advantages for biological fluidized bed reactors:

- The high biomass concentration achieved in the reactor leads to a small plant design, which could reduce the land area requirement by up to 80 per cent relative to conventional treatments.

- No moving parts.

- Reduced capital cost due to smaller reactor volumes and minimal space requirements.

The high recycle ratio generally used in AFBR in order to achieve fluidization gives another advantage for AFBR. During anaerobic conversions large amounts of $\mathrm{CO}_{2}$ are generated so the effluent tends to be alkaline. The effluent when mixed with the fresh influent provides enough alkalinity for $\mathrm{pH}$ control and stabilization (Marin et al. 1999). 


\section{3.2. Disadvantages of Anaerobic Fluidized Bed Reactor}

Some of the main disadvantages of the fluidized bed reactor are listed below:

- Temperature gradient reactions are not possible (Gupta, 1999).

- Limits in particle size distribution.

- Complex hydrodynamics make design and scale up difficult and requires skilled professionals to operate.

- High pumping power required fluidizing the bed (Metcalf and Eddy, 2002).

- The cost of the media in the fluidized bed reactor.

- The startup time period is relatively high (Metcalf \& Eddy, 2002).

- The need to carefully control bed fluidization. The fluidizing velocity must be sufficient for fluidization, but not so high that carriers are washed from the reactor (Rittmann and McCarty, 2001).

- Fines produced by particle breakup can be an operational problem.

- Pipe and vessel walls erode due to collisions of particles.

- Recycling of effluent may be necessary to achieve bed expansion, which makes the system more complex (Vigneswaran et al, 1986).

- Insufficient design data (Bolanos, 2000).

\subsubsection{Principles of Fluidization}

Fluidization occurs when a bed of particles is made to behave like a liquid by passing of a fluid (liquid, gas or liquid and gas) at an upflow velocity above the minimum 
fluidization velocity. Some fluidization characteristics of a Fluidized Bed Reactor are listed in the following sections.

\section{A. Minimum Fluidization Velocity}

Minimum fluidization velocity is necessary to fluidize a bed of particles. If the upflow velocity is not high enough the bed stays fixed and operates as a packed bed, while fluid flows between the interstitial spaces. However as the fluid flow is increased, the bed pressure drop increases until a maximum value is reached corresponding to the bed weight per unit of area. The frictional pressure drop of a fluidized bed column packed with solids is equal to the hydrostatic pressure drop of the bed. Several correlations exist to calculate minimum fluidization velocity in terms of Reynolds number. The wellknown Ergun Equation (Ergun, 1952) for minimum fluidization is written as:

$$
\frac{150\left(1-\varepsilon_{m f}\right) R e_{m f}}{\varepsilon_{m f}^{3}\left(\phi_{S}\right)^{2}}+\frac{1.75 R e_{m f}^{2}}{\varepsilon_{m f}^{3}\left(\phi_{S}\right)}-A r=0
$$

A description of these symbols is given in pages $\mathrm{xV}-\mathrm{xvi}$.

In the Eqn.1,

$$
R e_{m f}=\frac{d_{P} \rho_{l} U_{m f}}{\mu_{l}}
$$

and Archimedes Number is given as:

$$
A r=\frac{\left(\phi_{S} d_{p}\right)^{3}\left(\rho_{p}-\rho_{l}\right) g \rho_{l}}{\mu_{l}^{2}}
$$

When $\varepsilon_{\mathrm{mf}}$ and $\phi_{\mathrm{S}}$ are not known, Wen and Yu (1966) proposed the following correlation of the minimum fluidization velocity:

$$
R e_{m f}=\left((33.7)^{2}+(0.0408)^{2} A r\right)^{1 / 2}-(33.7) \text { for } 0.001 \leq \operatorname{Re}_{\mathrm{mf}} \leq 4000
$$


Later on Chen (1987) added the shape factor, $\phi_{\mathrm{s}}$, to the correlation and suggested the following equation for non spherical particles:

$$
R e_{m f}=\left(\left(33.7 \phi_{S}^{0.10}\right)^{2}+\left(0.0408 \phi_{S}^{-0.45}\right)^{2} A r\right)^{1 / 2}-\left(33.7 \phi_{S}^{0.10}\right)
$$

Therefore the minimum fluidization velocity can be calculated by rearranging the Reynolds number in Eqn. 2:

$$
U_{m f}=\frac{\operatorname{Re}_{m f} \mu_{l}}{d_{p} \rho_{l}}
$$

\section{B. Terminal Velocity}

To eliminate the carry over of particles from a Fluidized Bed during experimental runs the liquid velocity has to be maintained between $U_{\mathrm{mf}}$ and $U_{\mathrm{t}}$. Terminal velocity, $U_{\mathrm{t}}$, is the constant velocity that the free falling particles experience in a stagnant medium (Alvarez-Cuenca, 1995). In calculating the terminal velocity the smallest size of solids present in the bed are used to make sure that fines are not entrained and carried out of the top of the bed. The carrier terminal velocity is calculated by balancing the gravitational, buoyancy and drag forces for a particle:

$$
F_{D}+F_{B}=F_{G}
$$

The gravitational force is equal to the weight of the particle:

$$
F_{G}=\frac{4}{3} \pi r_{p}^{3} \rho_{p}
$$

The buoyant force is equal to the weight of the fluid replaced by the particle:

$$
F_{B}=\frac{4}{3} \pi r_{p}^{3} \rho_{l}
$$


The drag force is given as:

$$
F_{D}=\frac{C_{D} A_{p} \rho_{l} U^{2}}{2 g}
$$

Where, $C_{D}$ is the drag coefficient and $A_{p}$ is the cross sectional area of the particle

Substituting in Eqn. 7 we get:

$$
\frac{\rho_{l} U_{t}^{2} \pi d_{p}^{2} C_{D}}{8}=\frac{\pi d_{p}^{3} g\left(\rho_{p}-\rho_{l}\right)}{6}
$$

Rearranging, $U_{t}$ is determined as follows:

$$
U_{t}=\left[\frac{4\left(\rho_{p}-\rho_{l}\right) g d_{p}}{3 \rho_{l} C_{D}}\right]^{\frac{1}{2}}
$$

where the drag coefficient, $C_{D}$ is a function of the Reynolds number.

The following correlations of $C_{D}$ with $R e$ are developed for laminar, intermediate and turbulent flow regimes:

$$
\begin{array}{ll}
C_{D}=\frac{24}{R e_{p}} & R e_{p}<0.4 \\
C_{D}=\frac{10}{R e_{p}^{1 / 2}} & 0.4<R e_{p}<500 \\
C_{D}=0.43 & \text { for } R e_{p}>500
\end{array}
$$

The biofilm covered particle diameter can be determined according to Shieh et al. (1981):

$$
d_{b}=d_{p}+2 \sigma
$$

The biocovered particle density $\left(\rho_{b}\right)$ was calculated according to the Chang et al. (1991):

$$
\rho_{b}=\rho_{S}\left(\frac{d_{p}^{3}}{d_{b}^{3}}\right)+\rho_{b f}\left(1-\frac{d_{p}^{3}}{d_{b}^{3}}\right)
$$

where, biofilm wet density, $\rho_{\mathrm{bf}}$, was taken equal to $1100 \mathrm{~kg} / \mathrm{m}^{3}$ according to Buffiere et al. (1998). The terminal velocity for the biocovered particle is given by:

$$
U_{t}=\left[\frac{4\left(\rho_{b}-\rho_{l}\right) g d_{b}}{3 \rho_{l} C_{D}}\right]^{\frac{1}{2}}
$$




\section{Recycle Ratio}

A very high degree of effluent recycle is usually required in the Anaerobic Fluidized Bed in order to achieve the high HRT. The recycle ratio, $\mathrm{R}$ is given as the ratio of recycle flow rate $\left(Q_{r}\right)$ to the feed flow rate $(Q)$ :

$$
\mathrm{R}=\mathrm{Q}_{\mathrm{r}} / \mathrm{Q}
$$

The use of effluent recycle has its advantages and disadvantages. The main disadvantage is that recycle requires a large amount of energy. However, the following advantages listed below surpass the disadvantages (Marin et al. 1999; Vigneswaran et al, 1986):

- Help neutralize the $\mathrm{pH}$ of the incoming wastewater and reduce the alkalinity required (see section 2.3.1.).

- The effect of toxic biodegradable compounds is reduced.

- Minimize the effect of shock loadings.

- Compensate for variability of influent flow rate.

This would result in the system providing intimate contact between the biomass and the diesel fuel contaminated wastewater (NYSERDA, 1987).

When a high Hydraulic Residence Time is required to achieve the desired removal rates, a high recycling rate should be employed.

\subsection{Economics on A Comparative Evaluation of Aerobic and}

\section{Anaerobic Biodegradation Processes}

The degradation of diesel fuel hydrocarbons in groundwater and consequently the economics of the process are strongly influenced by the experimental conditions used. In this investigation the degradation of diesel fuel hydrocarbons has been carried out using an anaerobic fluidized bed reactor treating up to $1200 \mathrm{~L} / \mathrm{d}$ under different operating 
conditions such as HRT, OLR and influent diesel fuel concentration. Economics on a comparative evaluation of aerobic and anaerobic fluidized bed processes include three representative parameters: a) the annual operational cost; b) the cost of construction and installation; and c) income from biogas produced. Annual operational cost involves annual maintenance charges, cost of materials required for the bioprocess, labor requirement, chemical consumptions and energy requirement. Capital investment depends on land requirement, buildings and constructions. Operational costs of the aerobic biodegradation processes are high because of oxygen carriers, high aeration (power) and high sludge disposal. Moreover, the sludge (biomass) produced in aerobic processes has to be stabilized in classic anaerobic digesters before it can be safely disposed of (Sanders et al. 1996). However, the anaerobic biodegradation processes often require high recycling (power) and sludge disposal (low sludge production in comparison with the sludge production in aerobic processes), which increases the anaerobic process operational costs. The expenditure of sludge disposal assuming that sludge disposal would be entirely landfilled costs about $\$ 20$ /ton dry sludge (Yoon et al. 2004). According to Gavrilescu, (2002) the expenditure for sludge disposal in anaerobic fluidized bed processes was one-tenth of the expenditure in aerobic fluidized bed processes. Furthermore in anaerobic fluidized bed processes no aeration energy is needed. Since they are closed systems, the anaerobic processes lead to odor reduction during operation. Investment costs for an anaerobic fluidized bed process are often higher than those for an aerobic fluidized bed process (Gavrilescu, 2002). According to NYSERDA, (1987) the average annual payment-capital costs are $\$ 1,644,500$ for aerobic fluidized bed and $\$ 1,512,000$ for anaerobic fluidized bed for the same level of treatment 
achieved. Anaerobic biodegradation processes produce as byproduct a combustible gas called biogas, which contains 50-60\% methane, 30-40\% carbon dioxide, 1-5\% hydrogen and traces of nitrogen, hydrogen sulphide and water vapors (Duggal et al. 1987). While both aerobic and anaerobic fluidized bed processes have their advantages and disadvantages on the basis of a comparative evaluation, the anaerobic process was found to be the cheapest.

\subsection{Anaerobic Biological Treatment}

Numerous persistent organic compounds are degraded under anaerobic conditions, with the compound serving as a carbon or energy source for the biomass production. Although it is known that anaerobic microorganisms will degrade organic carbon, including petroleum hydrocarbons, in the absence of molecular oxygen, the biochemical mechanisms underlying the initial enzymatic oxidation reactions are largely less understood (Ball et al. 1996). Anaerobic degradation of diesel fuel hydrocarbons in soil was studied thoroughly using electron acceptors such as nitrate (Wilson and Bower, 1997; Alexander, 1999), ferric iron (Straub and Buchholz-Cleven, 1998) and sulfate (Brock et al. 1997; Alexander, 1999). According to Wiedemeier et al. (1999) anaerobic biodegradation is the most significant working process to remove benzene, toluene, ethylbenzene and xylene from groundwater. When diesel fuel hydrocarbons enter the groundwater system, rapid depletion of dissolved oxygen caused by increased levels of aerobic microbial respiration result in the establishment of anaerobic conditions (Fox, 1989). Certain requirements must be met for the anaerobic bacteria to degrade diesel fuel hydrocarbons such as absence of dissolved oxygen; availability of carbon sources for 
example diesel fuel hydrocarbons; electron acceptors and essential nutrients; and proper ranges of $\mathrm{pH}$, temperature, salinity, and redox potential. Depending on the type of electron acceptor present [nitrate, Fe (III), Mn (IV), sulfate], $\mathrm{pH}$ conditions, and redox potential, the anaerobic biodegradation can occur by denitrification, Mn (IV) reduction, Fe (III) reduction, sulfate reduction, or methanogenesis. These electron acceptors have a lower redox potential than oxygen and the rate of degradation may be lower (Erickson, 2000). Common species of microorganisms often associated with the degradation of diesel fuel hydrocarbons are listed in Table 2. Marquez-Rocha et al (2001) suggested that the biodegradation of diesel fuel hydrocarbons is often limited due to the low water solubility of these hydrocarbons.

TABLE 2. DIESEL FUEL DEGRADING MICROORGANISMS (ADAPTED FROM ERICKSON, 2000 AND ATLAS, 1981)

\begin{tabular}{|cccc|}
\hline \hline \multicolumn{3}{|c|}{ Diesel Degrading Microorganisms } \\
\hline Mycobacteria & Sphingomonas & Micrococcus & Corynebacterium \\
sp. & sp. & sp. & sp. \\
Escherichia & Pseudomonas & Pseudomonas & Brevibacterium \\
coli & aeruginosa & putida & sp. \\
Rhodococcus & Vibrio & Candida & Flavobacterium \\
sp. & sp. & sp. & sp. \\
Arthrobacter & Acinetobacter & Serratia & Achromobacter \\
sp. & sp. & sp. & sp. \\
\hline
\end{tabular}

Variations in the individual population of the biological community occur throughout the fluidized bed reactor with changes in organic loading, hydraulic loading, influent wastewater composition, $\mathrm{pH}$ and temperature (Metcalf and Eddy, 2002). 


\subsubsection{Effect of Temperature}

Anaerobic degradation is strongly influenced by temperature and can be grouped under one of the following categories: Psychrophilic $\left(0-20^{\circ} \mathrm{C}\right)$, mesophilic $\left(20-42^{\circ} \mathrm{C}\right)$ and thermophilic $\left(42-75^{\circ} \mathrm{C}\right)$ (Maier et al. 2000). In the mesophilic range, the bacterial activity and growth decrease by one half for each $10^{\circ} \mathrm{C}$ drop below $35^{\circ} \mathrm{C}$ (Metcalf and Eddy, 2002). Thus lower temperatures require longer degradation time.

\subsubsection{Effect of $\mathrm{pH}$}

Anaerobic reactions are highly $\mathrm{pH}$ dependent. The optimal $\mathrm{pH}$ range for anaerobic microorganisms is 6.7-7.3 (Maier et al. 2000). It is essential that wastewater contain enough buffer capacity to neutralize and prevent the build-up of localized acid zones. In general, sodium bicarbonate is used for supplementing the alkalinity since it is the only chemical that gently shifts the equilibrium to the desired value without disturbing the physical and chemical balance of the fragile microbial population.

\subsubsection{Effect of Nutrients}

The microorganisms in the anaerobic degradation process require micronutrients and trace elements such as nitrogen, phosphorus, sulphur, potassium, calcium, magnesium, iron, nickel, cobalt, zinc, manganese and copper for optimum growth. Although these elements are needed in extremely low concentration, the lack of these nutrients has an adverse effect upon the microbial growth and performance (Maier et al. 2000). 


\section{2..6. GAC as an Attachment Medium}

The removal of organic matter by a combination of adsorption and biological degradation in the Granular Activated Carbon Anaerobic Fluidized Bed Reactor (GACAFBR) was investigated first by Suidan et al. (1991). The GAC acted primarily as a support media for the attachment and growth of bacteria that form the biofilm. However, the adsorptive capacity of the GAC provides a second benefit in that it can cut-off peaks of influent concentration through adsorption, and latter desorbs the contaminants when the bacteria have reduced the aqueous phase concentration as found by Maloney et al. (2002). Fox et al. (1990) successfully used Granular Activated Carbon in an Anaerobic Fluidized Bed Reactor for anaerobic treatment of phenols formaldehyde contaminated wastewater. The GAC-AFB reactor was also proven to be an excellent treatment method for treating chlorinated hydrocarbons and treating soil wash fluids of PAH (polyaromatics hydrocarbons) contaminated soil, according to studies conducted by Flora et al. (1993) and Moteleb et al. (2002), respectively.

Some benefits of using GAC as a packing material in Anaerobic FBR are as listed:

- Higher biomass concentration maintained due to porous structure of GAC (Fox, 1989).

- Adsorption properties may help acclimate and enhance biomass degradation of toxic compounds by providing more exposure time.

The main limitation of GAC is the high cost of activated carbon, but for certain types of industrial and hazardous wastewaters the use of activated carbon is necessary. 


\section{CHAPTER 3. EXPERIMENTAL METHODS}

\subsection{Experimental Facility}

The anaerobic degradation of diesel fuel synthetic wastewater was carried out in the AFBR at the LWWTT at Ryerson University. Some of the equipment used in this project were: the fluidized bed reactor, vacuum stripper, water tank, feed tank, Gas Chromatograph-Mass Spectrometer, dissolved oxygen meter, spectrophotometer and $\mathrm{pH}$ meter. A more detailed list of these equipments will be discussed in the following sections.

\section{A. Vacuum Stripper}

To create anaerobic conditions it was important to remove dissolved oxygen from the water. Vacuum strippers are relatively economic for small amounts of water and they eliminate environmental interferences and problems associated with the use of oxygen scavengers (Bolanos, 2000). The vacuum stripper consisted of four sections mounted together using rubber gaskets to prevent air leakage. The column was made of clear PVC material with an internal diameter of $100 \mathrm{~cm}$ and a total height of $2.8 \mathrm{~m}$. The packing material used was tri-packs (hollow spherical shaped packing made of injection moulded plastic), with $157 \mathrm{~m}^{2} / \mathrm{m}^{3}$ specific surface area and $0.05 \mathrm{~m}$ nominal diameters. Vacuum strippers prevent plugging, fouling, nestling and wall channeling (Diaz, 2003). Prior to preparing the wastewater, tap water (cold and hot) filled the water tank and it was properly mixed. The water temperature was monitored in the range $30 \pm 1^{\circ} \mathrm{C}$. The water 
from the tank was then fed to the vacuum stripper column by means of the pressure drop between the vacuum stripper and the atmospheric pressure on the water tank.

\section{FIGURE 1. SCHEMATIC DIAGRAM OF THE VACUUM STRIPPER}

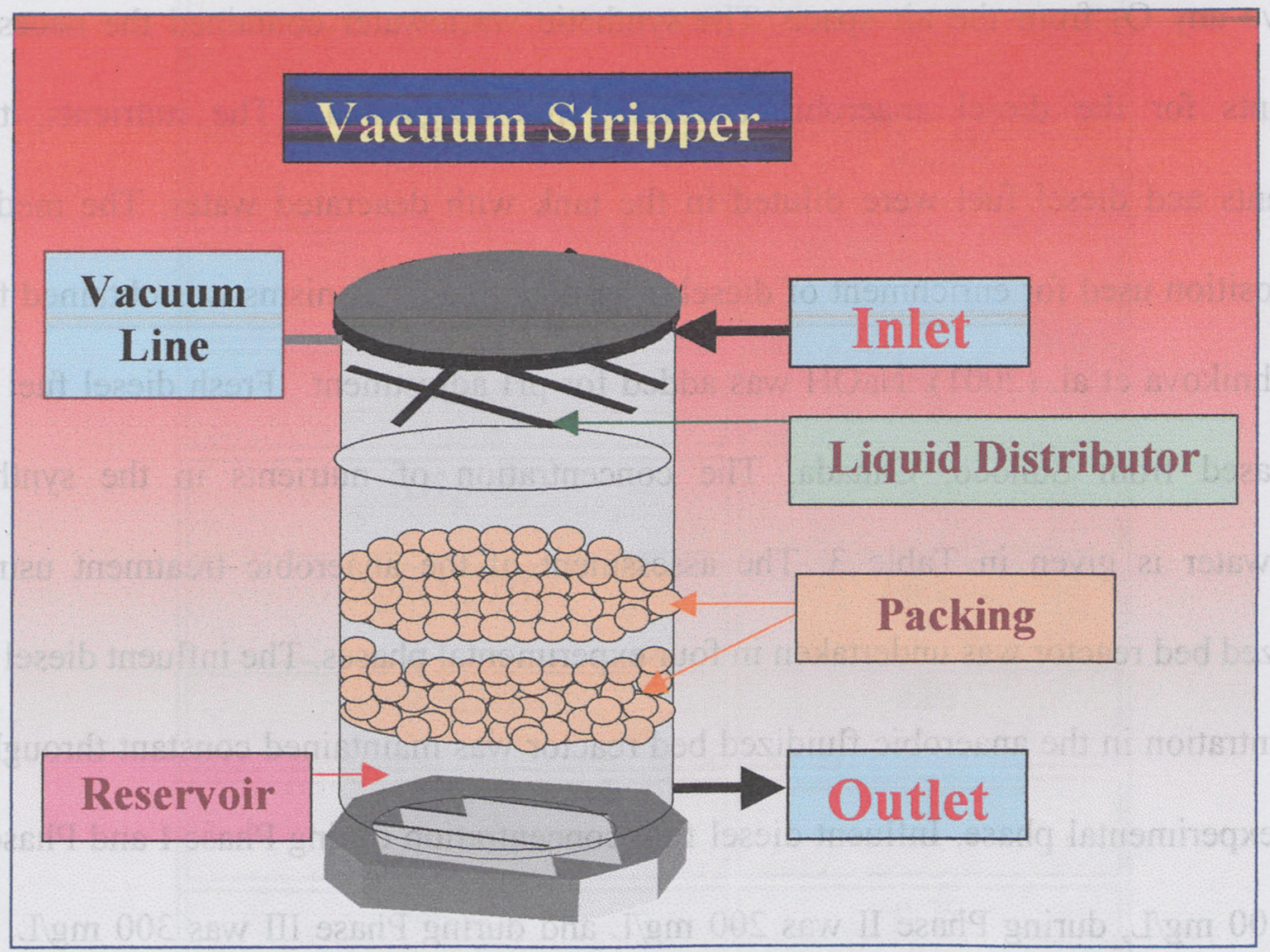

Vacuum stripper decreases the dissolved oxygen of tap water to $0.1-0.3 \mathrm{mg} / 1$ (see section 4.3.) by means of reducing the internal absolute pressure to $20 \mathrm{in}$. $\mathrm{Hg}$ absolute. Then the deaerated water from the bottom of the vacuum stripper was pumped into the feed tank (as shown in Figure 1). 


\section{B. Feed Tank and Synthetic Wastewater}

The feed tank had a capacity of $4500 \mathrm{~L}$ and was used to hold the synthetic wastewater. It had a diameter of $1.5 \mathrm{~m}$ and a stirrer installed inside to establish homogeneous mixing. The feed tank operated as a closed tank and $\mathrm{N}_{2}$ was purged to remove-any $\mathrm{O}_{2}-$ from the air space- The synthetic wastewater contained the necessary nutrients for the diesel anaerobic degrading microorganisms. The nutrients, trace elements and diesel fuel were diluted in the tank with deaerated water. The medium composition used for enrichment of diesel degrading microorganisms was obtained from Baryshnikova et al. (2001). $\mathrm{NaOH}$ was added for $\mathrm{pH}$ adjustment. "Eresh diesel fuel was purchased" from Sunoco, Canada. The concentration of nutrients in the synthetic wastewater is given in Table 3. The assessment of the anaerobic treatment using a fluidized bed reactor was undertaken in four experimental phases. The influent diesel fuel concentration in the anaerobic fluidized bed reactor was maintained constant throughout each experimental phase. Influent diesel fuel concentration during Phase-I-and Phase IV was $100 \mathrm{mg} / \mathrm{L}$, during Phase II was $200 \mathrm{mg} / \mathrm{L}$ and during Phase III was $300 \mathrm{mg} / \mathrm{L}$ ! The synthetic wastewater was pumped from the bottom of the feed tank to AFBR system. 
TABLE 3. NUTRIENTS USED FOR ANAEROBIC DIESEL FUEL DEGRADING MICROORGANISMS (ADAPTED FROM BARYSHNIKOVA et al. 2001)

\begin{tabular}{|c|c|}
\hline Compounds & $\begin{array}{l}\text { Concentration } \\
(\mathrm{mg} / \mathrm{L})\end{array}$ \\
\hline $\mathrm{NH}_{4} \mathrm{Cl}$ & 2.5 \\
\hline $\mathrm{CaCl}_{2} \mathbf{6 H}_{2} \mathrm{O}$ & 0.01 \\
\hline $\mathrm{MgCl}_{2} 4 \mathrm{H}_{2} \mathrm{O}$ & 0.02 \\
\hline $\mathrm{Na}_{2} \mathrm{HPO}_{4}$ & 10.0 \\
\hline $\mathrm{KH}_{2} \mathrm{PO}_{4}$ & 1.0 \\
\hline $\mathrm{MgSO}_{4} \cdot 7 \mathrm{H}_{2} \mathrm{O}$ & 0.2 \\
\hline $\mathrm{FeSO}_{4} .7 \mathrm{H}_{2} \mathrm{O}$ & 0.01 \\
\hline $\mathrm{NaCl}$ & 5.0 \\
\hline $\mathrm{Na}_{2} \mathrm{SO}_{4}$ & 0.25 \\
\hline
\end{tabular}

The AFBR was operated under 6 different Hydraulic Residence Times operating conditions during each experimental phase, with the aim of assessing the reactor performance. The values of diesel fuel concentration in the Feed Tank are summarized in Table 4. 
TABLE 4. DIESEL FUEL CONCENTRATION IN THE FEED TANK DURING EACH EXPERIMENTAL RUN

\begin{tabular}{|c|c|c|c|}
\hline Phase & $\begin{array}{c}\text { Experimental } \\
\text { Run }\end{array}$ & $\begin{array}{l}\text { HRT } \\
\text { (Hours) }\end{array}$ & $\begin{array}{l}\text { Diesel fuel Concentration } \\
\qquad(\mathrm{g} / \mathrm{L})\end{array}$ \\
\hline \multirow{6}{*}{ I } & 1 & 96 & 123.666 \\
\hline & 2 & 72 & 80.888 \\
\hline & 3 & 48 & 52.115 \\
\hline & 4 & 24 & 25.032 \\
\hline & 5 & 12 & 14.034 \\
\hline & 6 & 6 & 6.000 \\
\hline \multirow{6}{*}{ II } & 1 & 96 & 274.867 \\
\hline & 2 & 72 & 214.554 \\
\hline & 3 & 48 & 124.981 \\
\hline & 4 & 24 & 65.225 \\
\hline & 5 & 12 & 32.242 \\
\hline & 6 & 6 & 15.967 \\
\hline \multirow{6}{*}{ III } & 1 & 96 & 409.910 \\
\hline & 2 & 72 & 310.490 \\
\hline & 3 & 48 & 199.748 \\
\hline & $\overline{4}$ & 24 & 97.412 \\
\hline & 5 & 12 & 47.983 \\
\hline & 6 & 6 & 23.446 \\
\hline \multirow{6}{*}{ IV } & 1 & 96 & 123.666 \\
\hline & 2 & 72 & 80.888 \\
\hline & 3 & 48 & $52: 115$ \\
\hline & 4 & 24 & 25.032 \\
\hline & 5 & 12 & 14.034 \\
\hline & 6 & 6 & 6.000 \\
\hline
\end{tabular}




\section{Anaerobic Fluidized Bed Reactor (AFBR)}

The Anaerobic Fluidized Bed Reactor is the heart of this project. It consists of a semicylindrical column made of transparent $\mathrm{PVC}$ with internal diameter of $74 \mathrm{~cm}$ and a total height of $2.9 \mathrm{~m}$. A schematic of the AFBR with $300 \mathrm{~L}$ column volume is shown in Figure 2. The AFBR has a $1.4 \mathrm{~m}$ available column height and $0.215 \mathrm{~m}^{2}$ cross-sectional area.

FIGURE 2. SCHEMATIC DIAGRAM OF ANAEROBIC FLUIDIZED BED REACTOR

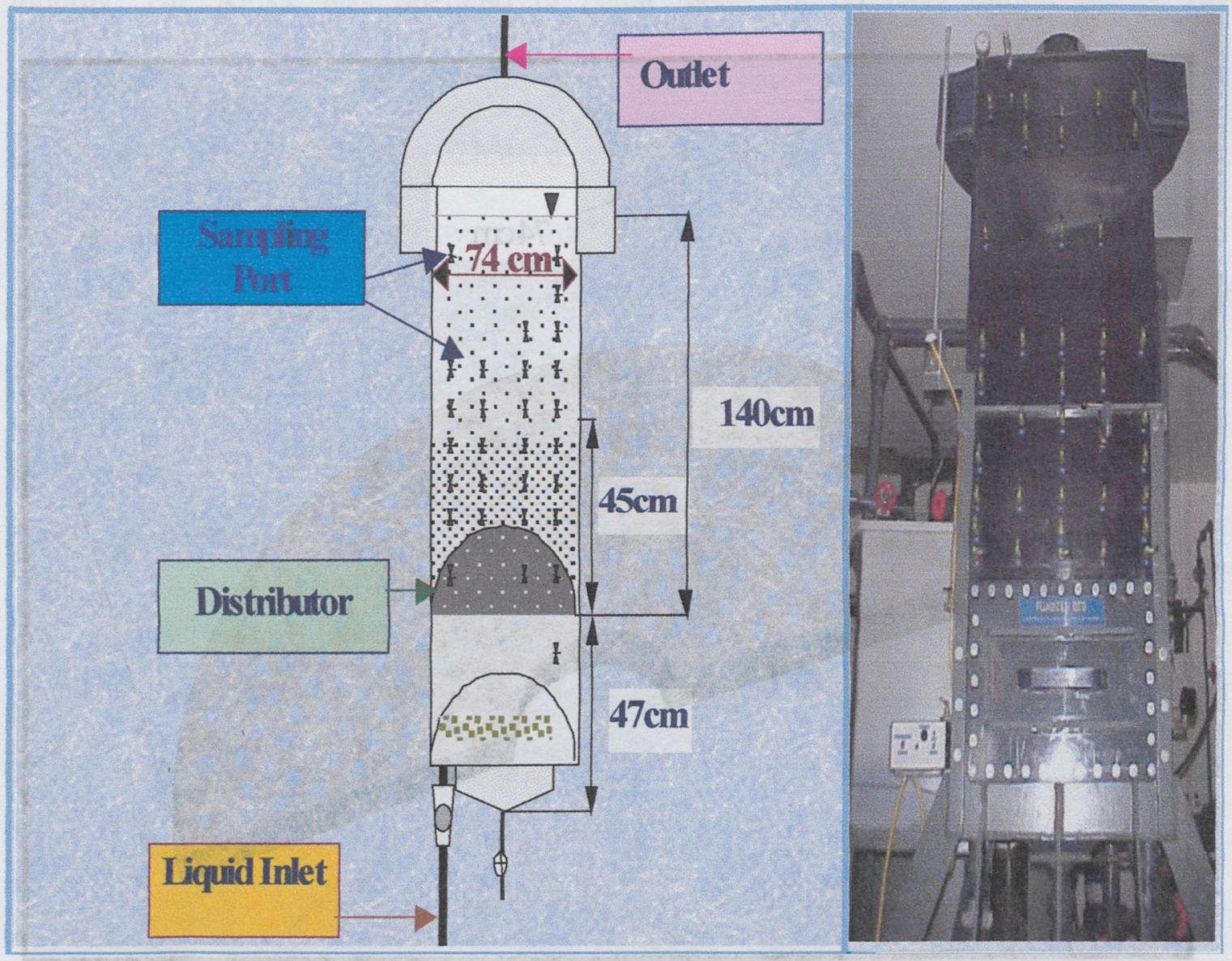




\section{Flow Distributor}

The Flow Distributor was a semi circular plate with diameter of $74 \mathrm{~cm}, 3.5 \mathrm{~cm}$ thickness and $0.215 \mathrm{~m}^{2}$ total area (Figure 3 ). The plate had 212 holes radially distributed with 986 holes $/ \mathrm{m}^{2}$. It was able to support the static weight of the bed, avoid the return of particles and to distribute the liquid uniformly over the cross section of the fluidized bed column.

\section{FIGURE 3. FLOW DISTRIBUTOR DIAGRAM}

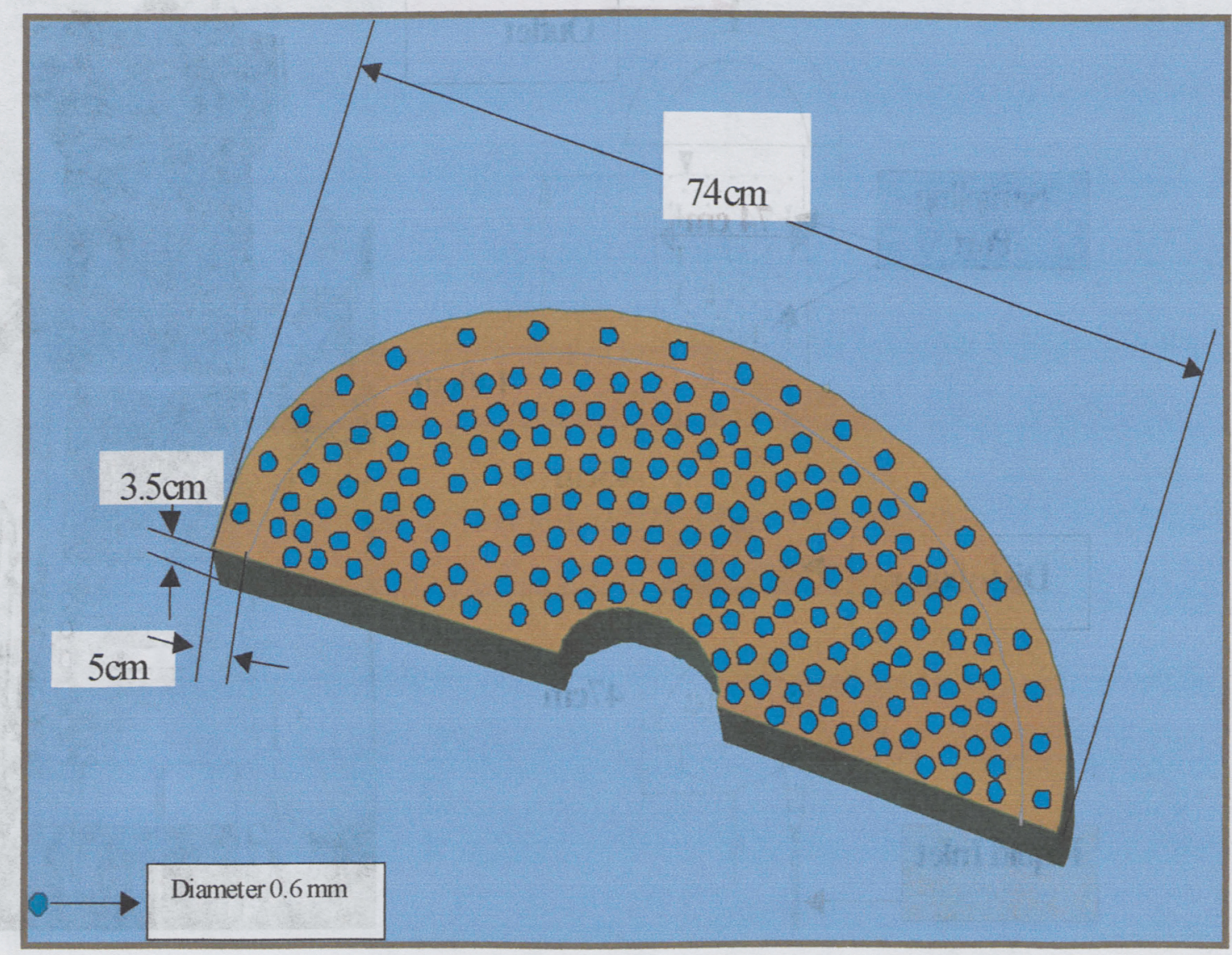




\section{E. Inoculation and Operation of AFBR}

The bioreactor was initially filled from the top of the column with granular activated carbon (GAC) $12 \times 20$ U.S. standard mesh (average $1.2 \mathrm{~mm}$ ). The AFBR was then inoculated by pouring approximately $10 \mathrm{~L}$ of fresh biomass solids into the reactor masing

column. The biomass was obtained from Rotating Biological Contactor from a previous experiment carried out in the Water and Wastewater Treatment Technologies Laboratory (Perryman, 2003). The biomass had been exposed to low levels of diesel fuel over many months. The AFBR was operated in batch mode for 65 days bioreactor for the acclimation of biomass and was fed with fresh diesel synthetic wastewater every 2 days until a stable degradation was achieved. Biofilm formation started after the third week and was fully developed after two months period. The bioreactor ran continuously from this time. The synthetic wastewater was pumped from the feed tank into the recycle line (as shown in Figure 4) of the anaerobic fluidized bed system using a model Vari Trac $1 / 2$

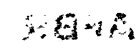
HP variable speed pump. Effluent recycle was applied with a model Vari Trac $11 \frac{1}{2} \mathrm{HP}$ pump to -maintain a bed expansion : of $40 \%$. This level of expansion -facilitated good mixing and prevented bed plugging. The feed flow rate was adjusted according to the Hydraulic Residence Time required in the AFBR column while maintaining a constant 80 $\mathrm{L} / \mathrm{min}$ influent flow rate in the reactor. 
FIGURE 4. PROCESS FLOW DIAGRAM OF THE ANAEROBIC FLUIDIZED BED REACTOR

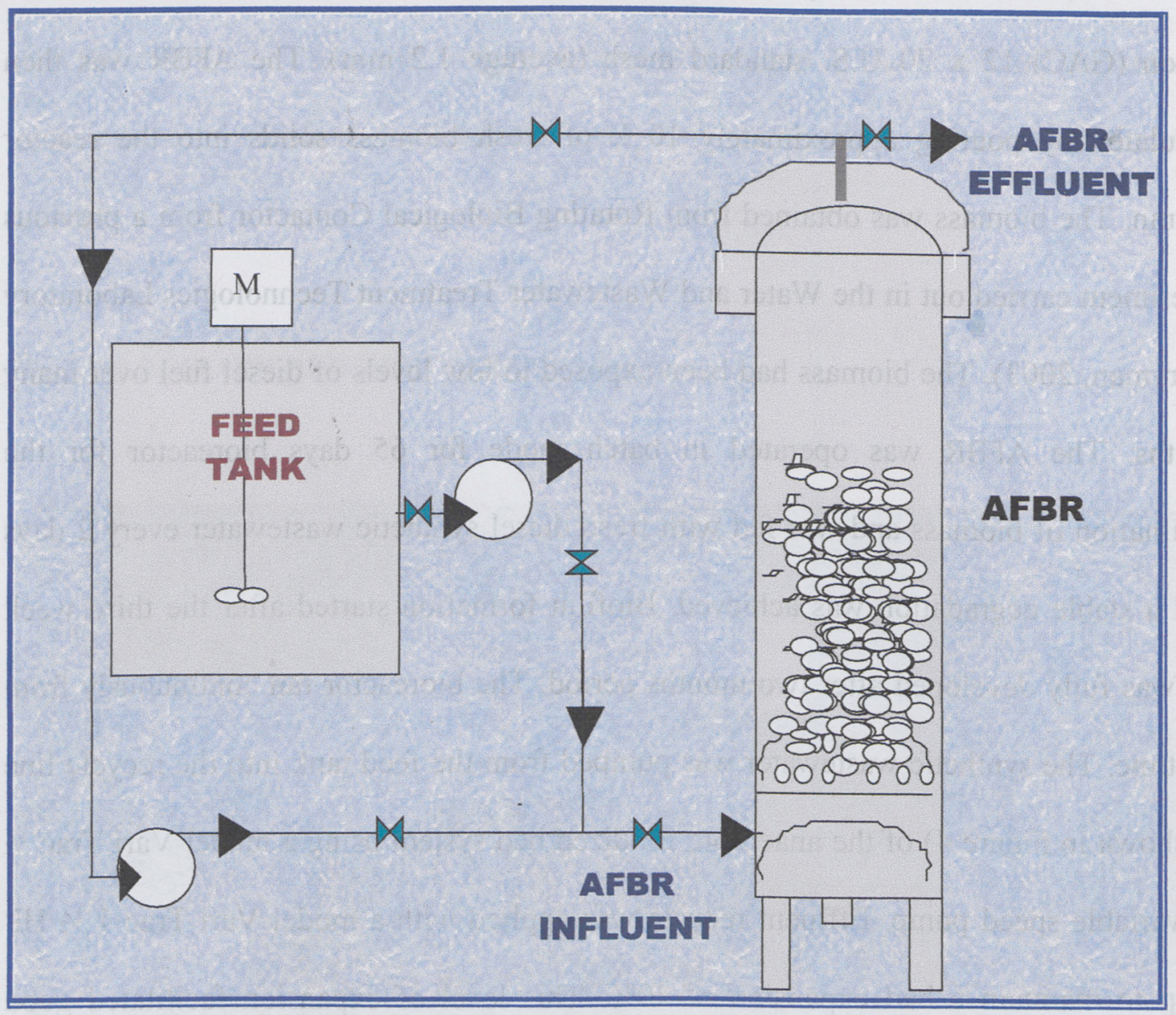

The fluidizing velocity during the entire project was kept high enough so that all particles were in the fluidized state. An operation velocity of $0.0062 \mathrm{~m} / \mathrm{s}=0.62 \mathrm{~cm} / \mathrm{s}$ was selected for feedwater based on minimum fluidization velocity and terminal velocity for GAC particles. Table 5 summarizes the operating conditions for the AFBR. 
TABLE 5. OPERATING CONDITIONS FOR ANAEROBIC FLUIDIZED BED REACTOR

\begin{tabular}{|c|c|}
\hline Characteristic & Reactor Value \\
\hline $\begin{array}{c}\text { Mean GAC Size, mm } \\
\text { Bed Expansion, \% }\end{array}$ & $\begin{array}{l}1.2 \\
40\end{array}$ \\
\hline Liquid Superficial Velocity (including recycle), $\mathrm{cm} / \mathrm{s}$ & 0.62 \\
\hline Operational Bed Height, $m$ & 1.4 \\
\hline (1) pH Range & $6.7-7.3$ \\
\hline Radius of Reactor, m & 0.37 \\
\hline GAC material submergence, $\%$ & 100 \\
\hline Temperature, ${ }^{\circ} \mathrm{C}$ & $30 \pm 1$ \\
\hline
\end{tabular}

Hydraulic Residence Time in the reactor is given as a combination of the fluidizing velocity in with the maximum operating bed height of $1.4 \mathrm{~m}$ in the AFBR, (NYSERDA, 1987):

$$
H R T=\frac{V}{Q}=\frac{H \cdot A}{Q}=\frac{H}{U}
$$

Substituting the experimental data in Eqn. 20 we get:

$$
H R T=\frac{1.4(\mathrm{~m})}{0.0062(\mathrm{~m} / \mathrm{s})}=225 \mathrm{~s}=3.75 \mathrm{~min}
$$

Since the hydraulic residence time required to achieve good effluent quality would be in the order of $96,72,48,24,12,6$ hours a recycle flow was necessary. 
Recycle Ratio, $R$, (ratio of volume of fluid returned to the reactor entrance to volume of fluid leaving the system) of $1537,1158,761,380,189$ and 94 would be required for HRT of $96 \mathrm{hr}, 72 \mathrm{hr}, 48 \mathrm{hr}, 24 \mathrm{hr}, 12 \mathrm{hr}$ and $6 \mathrm{hr}$, respectively.

For example, when HRT of 6 hours was required the upflow velocity was reduced to:

$$
(1.4 \mathrm{~m} / \text { hour })=0.2333 \mathrm{~m} / \mathrm{h}=6.48148 \times 10^{-5} \mathrm{~m} / \mathrm{s} \text {. }
$$

The difference in flow between the required fluidizing velocity of $0.0062 \mathrm{~m} / \mathrm{s}$ and the $6.48 \times 10^{-5} \mathrm{~m} / \mathrm{s}$ had to be made up by recycle (NYSERDA, 1987):

$$
R=\frac{(0.0062 \mathrm{~m} / \mathrm{s}-0.0000648148 \mathrm{~m} / \mathrm{s})}{0.0000648148 \mathrm{~m} / \mathrm{s}}=94
$$

Bed Expansion was calculated from an average bed height $(\mathrm{H})$ by the formula given by Yu et al. (1999):

$$
E x=\frac{H_{f}-H_{o}}{H_{o}} \cdot 100 \%
$$

Where $\mathrm{H}_{0}$ is the static bed height;

$\mathrm{H}_{\mathrm{f}}$ is the fluidized bed height.

The fluidized bed of particles had a clear but fluctuated surface that was visually checked. Then, substituting the experimental data in Eqn. 22 we get:

$$
E x=\frac{H_{f}-H_{O}}{H_{O}} \cdot 100 \%=\frac{0.42 m-0.3 m}{0.3 m} \cdot 100 \%=40 \% \text { Expansion of Bed }
$$

The volume of bed at minimum fluidization velocity is given as:

$$
V_{B}=H_{m f} \times A=0.38(m) \times 0.215\left(m^{2}\right)=0.0817 m^{3}
$$

Bed Density can be calculated by

$$
\rho_{B}=\frac{W_{S}}{V_{B}}=\frac{12.5(\mathrm{~kg})}{0.0817\left(\mathrm{~m}^{3}\right)}=153 \frac{\mathrm{kg}}{\mathrm{m}^{3}}
$$


Bed Voidage, $\varepsilon_{\mathrm{mf}}$, is the volume of vessel occupied by liquid under minimum fluidization conditions in the liquid-solid phase fluidized bed reactor:

$$
\varepsilon_{m f}=1-\frac{\rho_{B}}{\rho_{p}}=1-\frac{153\left(\frac{\mathrm{kg}}{\mathrm{m}^{3}}\right)}{1500\left(\frac{\mathrm{kg}}{\mathrm{m}^{3}}\right)}=0.898
$$

Solids Hold up of the bed is given by:

$$
\varepsilon_{s}=\frac{W_{s}}{\rho_{s} A H}
$$

Where $\mathrm{W}_{\mathrm{s}}$ is the total GAC mass $=12.5 \mathrm{~kg}$ (see section 3.1.4.).

$$
\varepsilon_{s}=\frac{12.5(\mathrm{~kg})}{\left(1500\left(\frac{\mathrm{kg}}{\mathrm{m}^{3}}\right)\right)\left(0.215\left(\mathrm{~m}^{2}\right)\right)(0.42(\mathrm{~m}))}=0.093
$$

The following equation is always true in the liquid-solid fluidized bed:

$$
\varepsilon_{s}+\varepsilon_{l}=1
$$

Where, $\varepsilon_{s}$ and $\varepsilon_{1}$ are the solid and liquid volume fractions, respectively.

$$
\varepsilon_{l}=1-0.093=0.907
$$

The Hydraulic Diameter for the semi cylindrical column is four times the hydraulic radius (OIson, 1980)

$$
D_{H}=4 R_{H}=4 \frac{\left(\pi R_{C}^{2}\right),}{2\left(\pi R_{C}+2 R_{C}\right)}=4 \frac{\left(3.14 \cdot 0.37^{2}\left(\mathrm{~m}^{2}\right)\right)}{2[(3.14 \cdot 0.37(\mathrm{~m}))+(2 \cdot 0.37(\mathrm{~m}))]}=0.452 \mathrm{~m}
$$

Reynolds number at fluidizing velocity is an indicator of the turbulence of the fluid flow through a control volume. Flow Reynolds number for the semi cylindrical column at $30^{\circ} \mathrm{C}$ is calculated by:

$$
R_{e}=\frac{U D_{H} \rho_{l}}{\mu_{l}}=\frac{(0.0062(\mathrm{~m} / \mathrm{s}))(0.45215(\mathrm{~m}))\left(995.7\left(\mathrm{~kg} / \mathrm{m}^{3}\right)\right)}{\left.0.798 \cdot 10^{-3}\left(\mathrm{Ns} / \mathrm{m}^{2}\right) \mathrm{s}^{2} \mathrm{t}\right)}=3.5 \times 10^{3}
$$




\section{F. Sampling Ports}

During this investigation feedwater samples were taken from three points of the AFBR: inlet, midpoint (45 cm above the Flow Distributor) and outlet (Figure 5). The feedwater samples were used to measure diesel fuel concentration, and COD levels. The solid samples were taken from above the distributor and the top of the AFBR column and were used to measure the biofilm thickness.

FIGURE 5. SAMPLING PORTS IN THE ANAEROBIC FLUIDIZED BED REACTOR

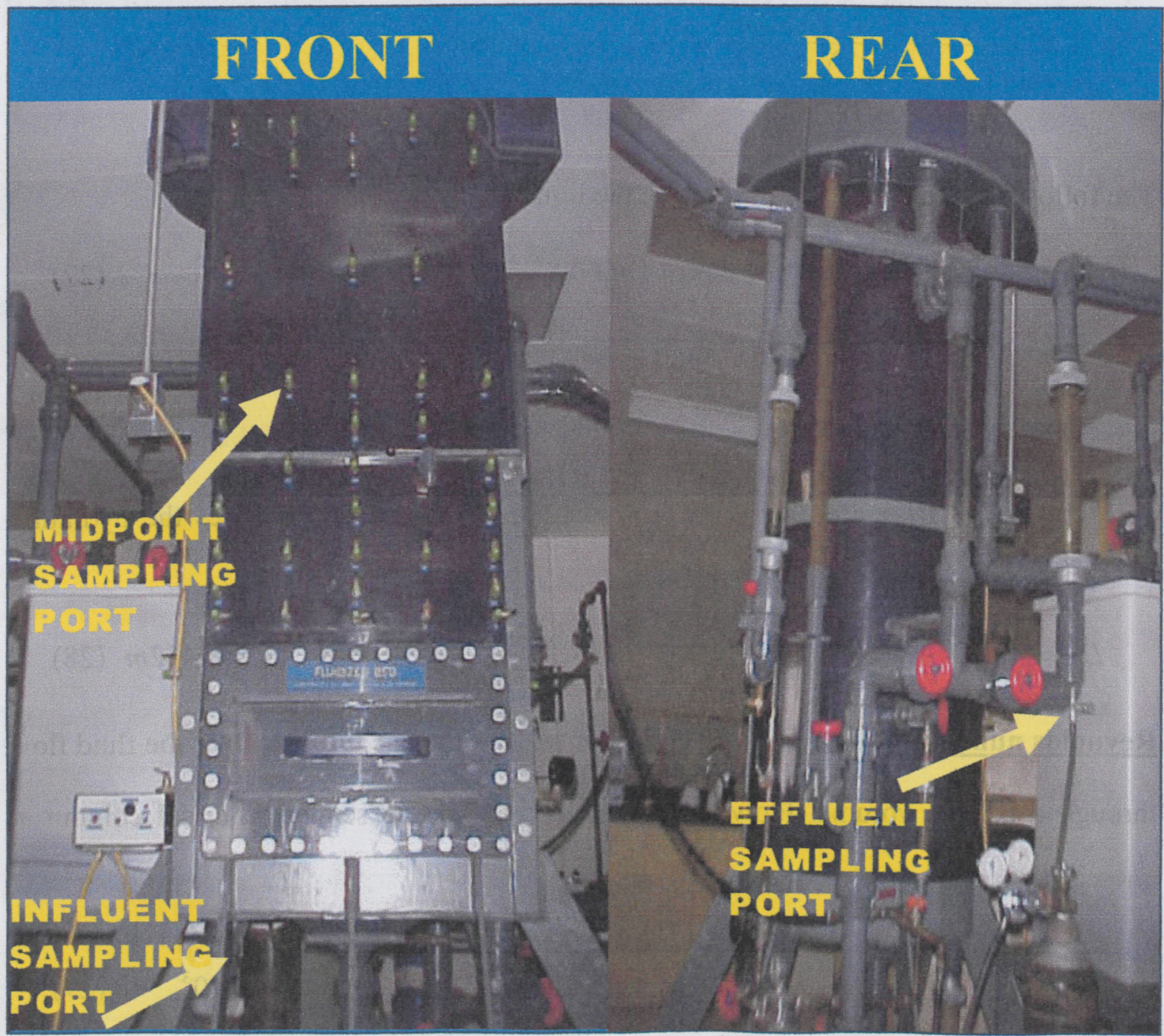




\section{G. Reactor Media}

Several media types were compared in order to decide the type for use in this project.

FIGURE 6. MEDIA TYPES A) LAVA ROCK; B) GRANULAR ACTIVATED CARBON; C) CORK-METAL; D) TRI-PACK;

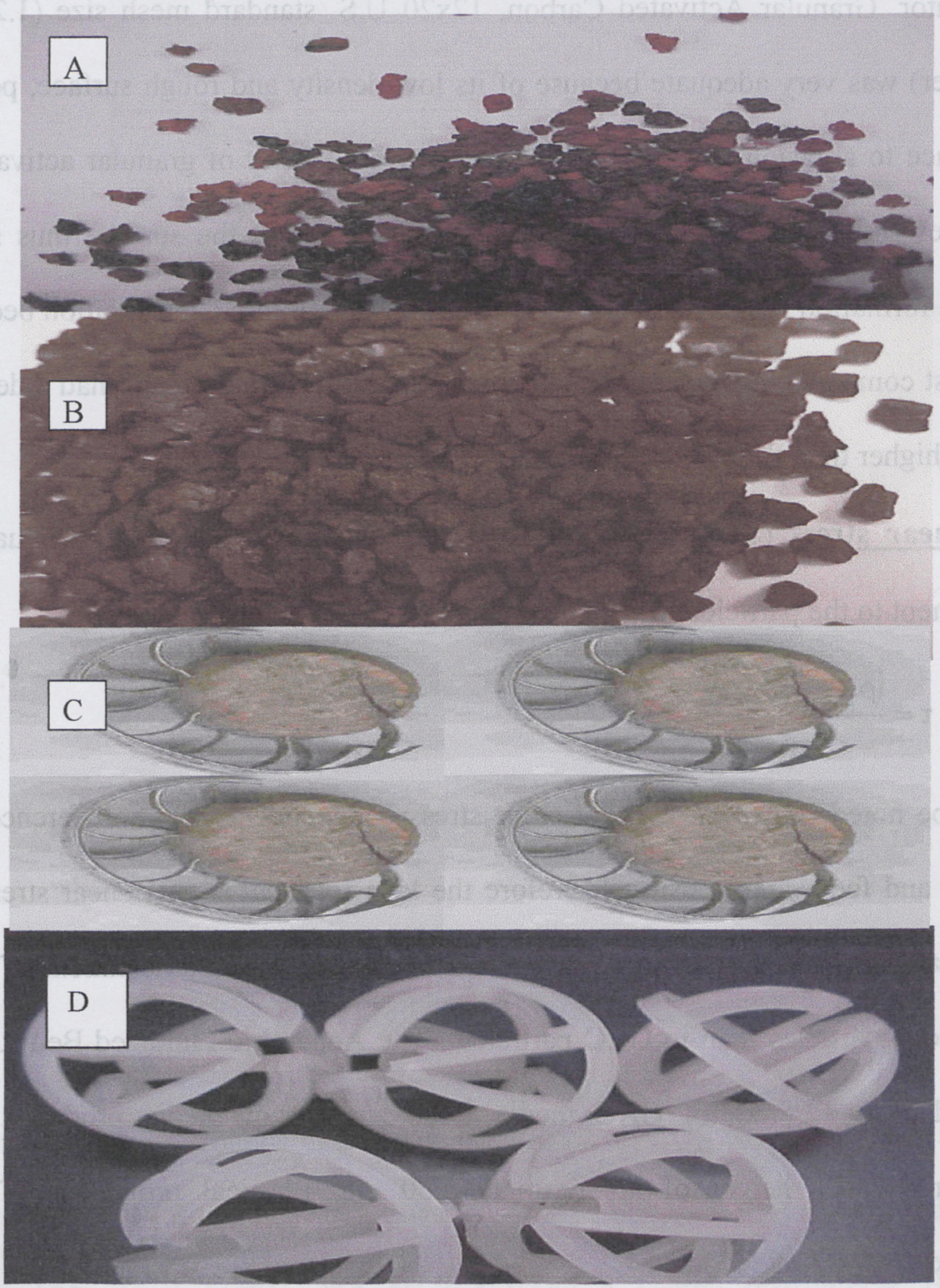


Low-density Tri Pack (12.7 mm diameter) was considered as an attachment medium in the fluidized bed reactor but was discarded due to its density being lower than that of water. Then Cork - Metal (35mm) media was tested for its low density $\left(1.1 \mathrm{~g} / \mathrm{cm}^{3}\right)$ but was discarded because after less than a day in the AFBR the cork separated from the metal. The cork emerged to the top of the bed and the metal sunk resting on the flow distributor. Granular Activated Carbon, $12 \times 20$ U.S. standard mesh size (1.2mm mean diameter) was very adequate because of its low density and rough surface, porosity and resistance to abrasion. In addition, the adsorptive property of granular activated carbon increases the concentration of soluble organic matter on the surface thus stimulating biofilm formation (Padron, 2004). Lava Rock was taken into consideration because of its low cost compared to the GAC. However it was discarded because it had a density (1.79 $\mathrm{g} / \mathrm{cm}^{3}$ ) higher than the density of GAC $\left(1.5 \mathrm{~g} / \mathrm{cm}^{3}\right)$.

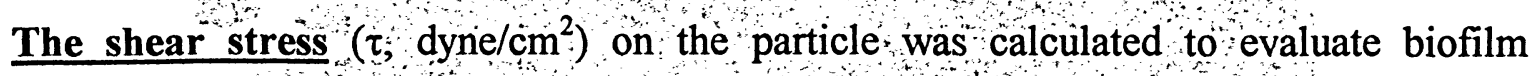
attachment to the particles (Chang et al. 1991)

$$
\tau=\frac{\left(\rho_{p}-\rho_{l}\right) g \cdot r_{p}}{3}
$$

It can be noted from Eqn. 30 that shear stress is dependent on the difference of media density and feedwater density. Therefore the lava rock has higher shear stress than the GAC particles. As a result it would be more difficult for the attachment of biofilm in Lava Rock particles than in GAC particles. The Anaerobic Fluidized Bed Reactor was charged with $12.5 \mathrm{~kg}$ of GAC media. This amount of media produced an initial unexpanded bed height of approximately $30 \mathrm{~cm}$. Physical properties of GAC are presented in Table 6. 
TABLE 6. PHYSICAL AND OPERATING PROPERTIES OF GAC MEDIA USED IN THIS STUDY

\begin{tabular}{|c|c|}
\hline GAC & \\
\hline Particle density $\left(\mathrm{g} / \mathrm{cm}^{3}\right)$ & 1.5 \\
\hline Terminal Velocity $(\mathrm{cm} / \mathrm{s})$ & 3.8 \\
\hline $\begin{array}{l}\text { Minimum Fluidization } \\
\text { Velocity }(\mathbf{c m} / \mathbf{s})\end{array}$ & 0.2 \\
\hline Sphericity & 0.8 \\
\hline Mean Particle size (cm) & 0.12 \\
\hline Pore Volume $\left(\mathrm{cm}^{3} / \mathrm{g}\right)$ & 0.94 \\
\hline $\begin{array}{l}\text { Total surface Area } \\
\left(\mathrm{m}^{2} / \mathrm{g} \text { dry weight) }\right.\end{array}$ & 650 \\
\hline
\end{tabular}

\subsection{Analytical Methods}

\section{A. $\mathbf{p H}$}

In order to avoid any change in $\mathrm{pH}$ from the release of $\mathrm{CO}_{2}$, the $\mathrm{pH}$ of the feedwater was analyzed instantly following withdrawal of liquid sample. $\mathrm{NaOH}$ was added for $\mathrm{pH}$ adjustment. The $\mathrm{pH}$ was measured off-line using a Hanna instruments HI 9025 microcomputer $\mathrm{pH}$ meter. 


\section{B. Chemical Oxygen Demand (COD)}

The COD was analyzed with the Closed Reflux, Colorimetric method as described in Standard Methods APHA 5220D (APHA, AWWA, and WPCF, 1995). The COD measurement is a very important test for assessing the AFB Reactor performance. COD by definition is the equivalent amount of oxygen necessary to breakdown organic matter to $\mathrm{CO}_{2}$ and $\mathrm{H}_{2} \mathrm{O}$ under strong oxidizing agents (Maier et al, 2000). COD is measured by quantitative analysis of wastewater oxidation with potassium dichromate $\left(\mathrm{K}_{2} \mathrm{Cr}_{2} \mathrm{O}_{7}\right)$ in the presence of sulfuric acid and silver and is expressed in milligram per liter. COD was determined using the COD high range digestion reagent filled vials (VWR International, Canada) and COD reactor (Bioscience, Canada). A feedwater sample $(0.5 \mathrm{~mL})$ was added carefully down the side of the vial so that it formed a layer on top of the reagents. The cap was closed and the contents of the sealed vial were thoroughly mixed by shaking. Then the twist-cap vial was placed in the preheated COD heater block and digested for 2 hours at $150^{\circ} \mathrm{C}$ (Figure 7). Next, vials were removed from the heater block and allowed for cooling. A procedural blank was required to zero the absorbance reading prior to any sample measurement. The blank was prepared following the same procedure as above but instead of feedwater sample, $0.5 \mathrm{~mL}$ of distilled water was added. COD concentrations (mg/l) were directly read using the spectrophotometer Analyst Model 975MP microprocessor operated at $608 \mathrm{~nm}$ wavelength. The COD process is very fast to perform ( 2 hours) compared to BOD testing (5 days). A disadvantage of the COD method is associated with the fact that strong oxidants may breakdown more of the organic materials than a natural process would. Therefore, COD is only an approximation of the natural degradation of organic material in nature (Metcalf and Eddy, 2002). 


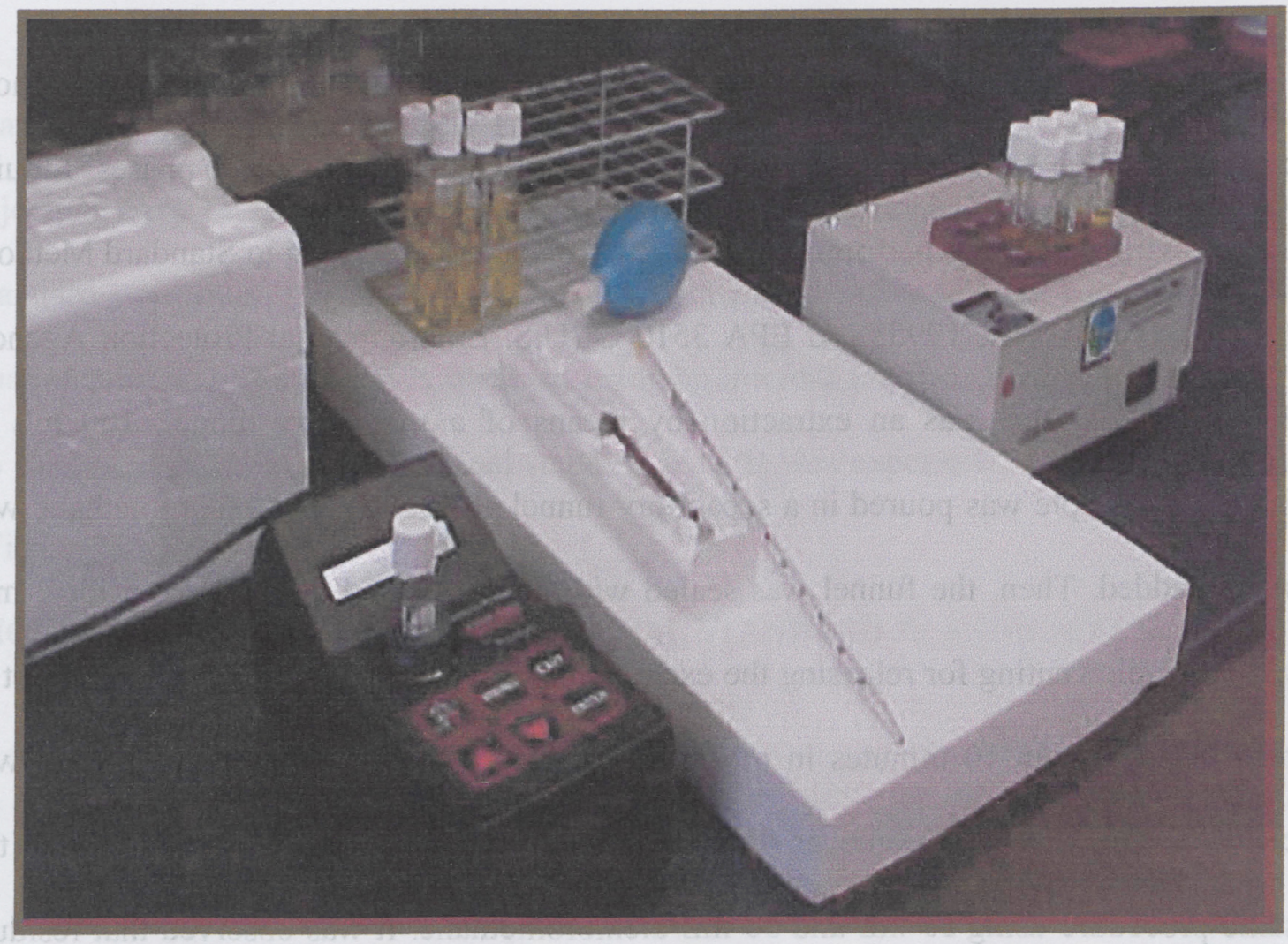

\section{White Light Microscopy}

Microscopic observations were made on both clean particles, and on particle samples obtained from the fluidized bed reactor. The microscope, a Leica DML series, was equipped with a trinocular head (video camera + eye pieces), so that white light images could be obtained. 


\section{Liquid-Liquid Extraction}

Liquid-Liquid Extraction is a process that allows the separation of two or more components due to their different solubilities in two immiscible liquid phases. LiquidLiquid extractions were performed with dichloromethane according to Standard Methods APHA 6410 (APHA, 1995) and EPA 3510 C (U.S. Environmental Protection Agency, 2004). Briefly, this was an extraction by means of a separatory funnel. $100 \mathrm{~mL}$ of feedwater sample was poured in a separatory funnel and $35 \mathrm{~mL}$ of dichloromethane was slowly added. Then, the funnel was sealed with a stopper and it was shaken for $2 \mathrm{~min}$ with periodic venting for releasing the excess pressure. Next, the organic layer was let to rest for more than 10 minutes in order to separate from water. The bottom layer was collected in a $250 \mathrm{ml}$ erlenmeyer flask. Two more extractions were made following the same procedure using $35 \mathrm{~mL}$ and $30 \mathrm{~mL}$ dichloromethane. It was observed that residual water remained in the dichloromethane layer. The extracts were dried with anhydrous sodium sulfate granular, $\mathrm{Na}_{2} \mathrm{SO}_{4}$ to remove any residual water from the dichloromethane layer. Next, $1 \mathrm{~mL}$ of the organic layer along with $20 \mu \mathrm{l}$ Internal Standard were transferred in a GC autosampler vial for GC-MS analysis.

FIGURE 8. DIAGRAM OF LIQUID-LIQUID EXTRACTION
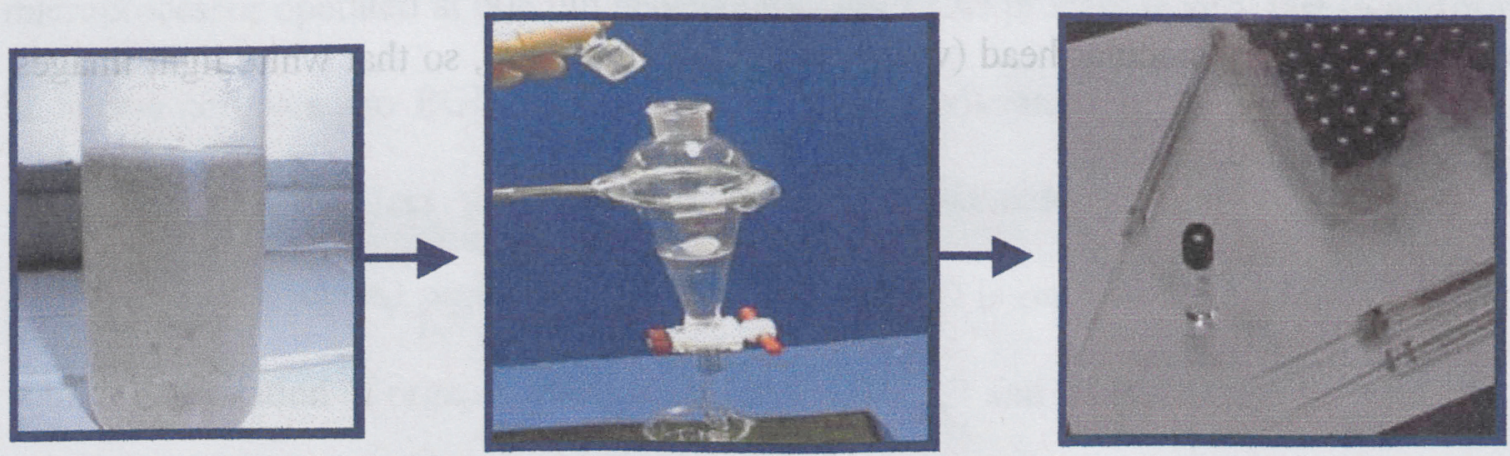


\section{E. Internal Standard}

In order to improve the precision of quantitative GC-MS results, an internal standard was added to each sample. Internal standard application corrects any deviations from injection, flow rate and variations in GC-MS column conditions. In general, the internal standard used must have similar properties with the analyte and should elute near the analytical peaks. The precision obtained using an internal standard varies from 0.5 to 1.0 $\%$ (Skoog et al. 1997). The internal standard used in this experiment was $5 \alpha$ Androstane (Figure 9).

FIGURE 9. THE STRUCTURE OF INTERNAL STANDARD $5 \alpha$ ANDROSTANE

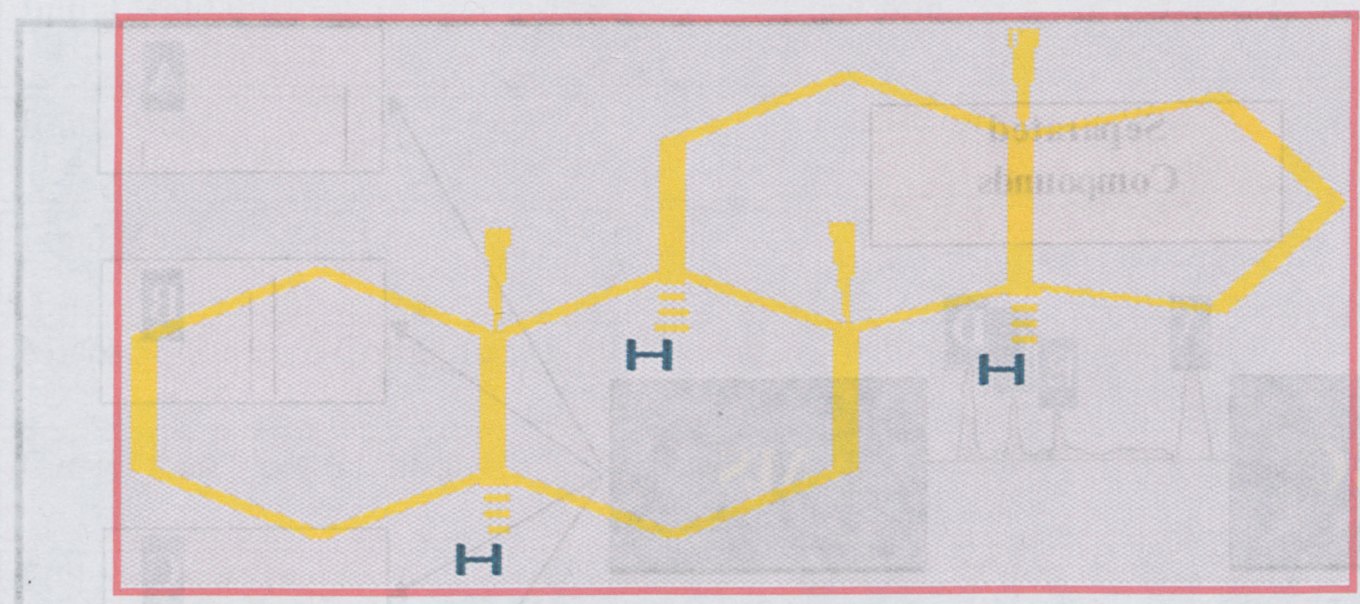

\section{F. Gas Chromatography - Mass Spectrometry (GC-MS)}

GC-MS analyses were carried out using Perkin Elmer Autosystem XL. Gas Chromatograph coupled with Turbomass Mass Spectrometer. GC-MS is a powerful instrument for determining the concentration of diesel fuel (Erickson, 2000; Zink and Lorber, 1995). Using these instruments together makes possible both the separation of 
different compounds in complex mixtures and the identification of them on MS (Figure 10). The chromatography employed a MDN-5S Supelco column $35 \mathrm{~m} \times 0.25 \mathrm{~mm}$ (I.D.) with a film thickness of $0.25 \mu \mathrm{m}$. The inlet temperature was maintained at $250^{\circ} \mathrm{C}$, while the column operating temperature was programmed as follows: The column was initially heated to $80{ }^{\circ} \mathrm{C}$ and maintained at this temperature for $1 \mathrm{~min}$. It was subsequently increased to $300{ }^{\circ} \mathrm{C}$ at a rate of $25^{\circ} \mathrm{C} / \mathrm{min}$, and maintained at $300^{\circ} \mathrm{C}$ for 7 $\min$. The transfer line temperature was maintained at $275^{\circ} \mathrm{C}$ (Table 7)

FIGURE 10. DIAGRAM OF A GC-MS COMBINATION

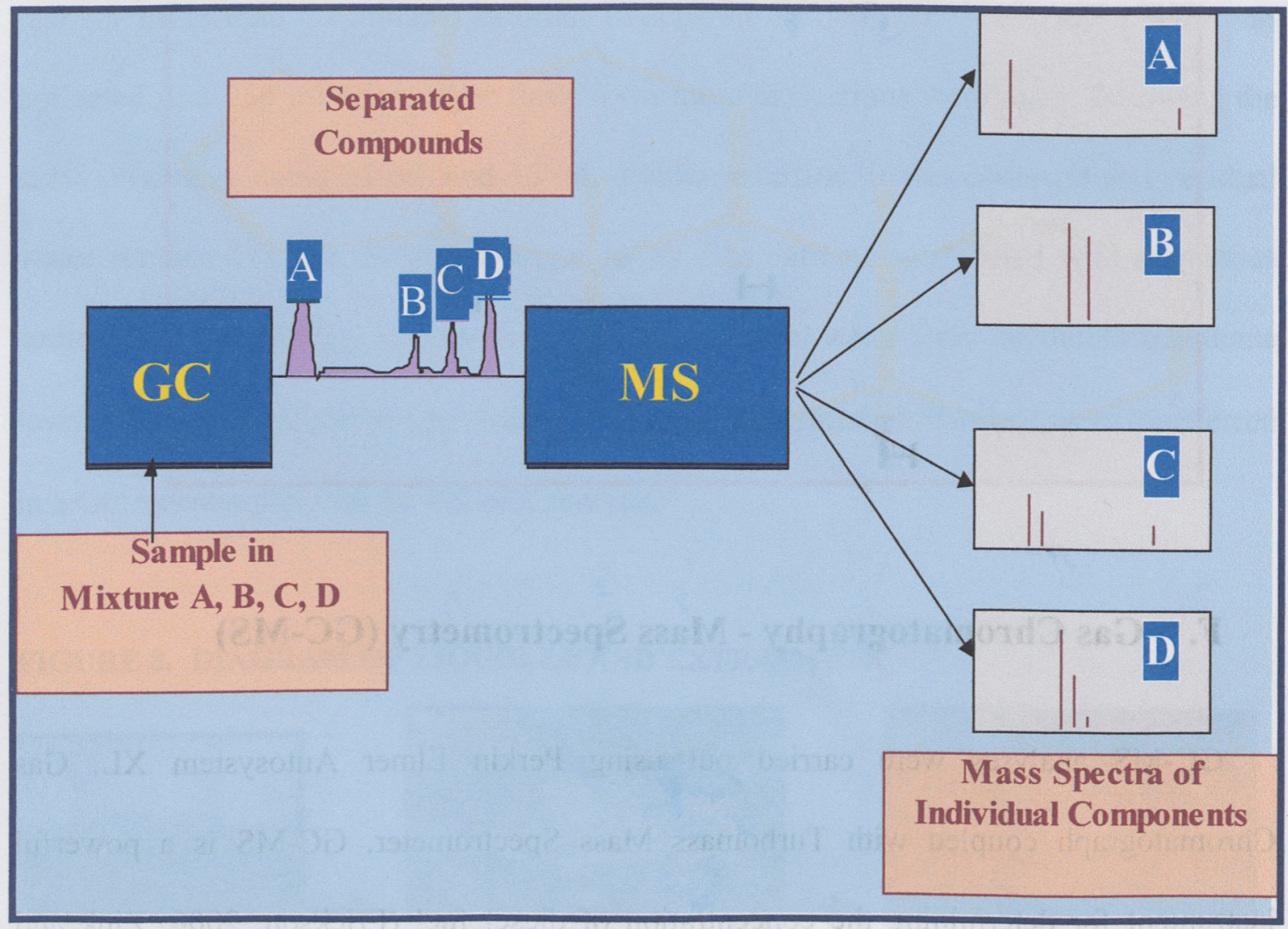


The mass spectrometer was operated in the electron ionization mode. The mass range employed was 50-350 amu (atomic mass unit) with a time scan time of $1 \mathrm{sec} / \mathrm{scan}$.

TABLE 7. GC-MS INSTRUMENTAL CONDITIONS

\section{TurboMass GC Mass Spectrometer -PERKIN ELMER}

Injection Port Temperature $250^{\circ} \mathrm{C}$

MS Source Temperature $275^{\circ} \mathrm{C}$

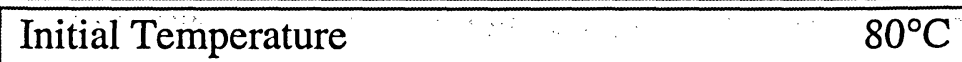

Initial Hold $1 \mathrm{~min}$

Ramp Rate $25^{\circ} \mathrm{C} / \mathrm{min}$. to $300^{\circ} \mathrm{C}$

Final Hold $7 \mathrm{~min}$.

MDN-5S Supelco Column 35m x $0.25 \mathrm{~mm}$ (I.D.) with a film thickness of $0.25 \mu \mathrm{m}$

Carrier Gas Flow (Helium) $2 \mathrm{~mL} / \mathrm{min}$

Full ions scan range:

$50-350$ atomic mass units 


\section{H. Calibration Curve for GC-MS}

Prior to collecting and testing wastewater samples from the Anaerobic Fluidized Bed Reactor, a calibration curve was prepared for diesel fuel concentration identified by the GC/MS. Dichloromethane (DCM) was determined to be the best solvent among many solvents applied (hexane, dichloromethane, methanol and acetone) as a mobile phase for diesel fuel hydrocarbons (Perryman, 2003). Samples for Calibration Curve of diesel fuel in $\mathrm{DCM}$ were prepared, ranging from $25 \mathrm{ppm}$ to $400 \mathrm{ppm}$. Quantitative data were produced by GC-MS. Ratio of the integrated area under the curve for total diesel hydrocarbons to the integrated area of internal standard was the basis for determining the amount of diesel fuel in the unknown samples. The unknown extracted samples were not concentrated hence the ratio shows the true values for diesel fuel concentration. Dieselextracted standards were calculated by means of the experimentally determined extraction efficiency. The extraction efficiency was found to be an average of $50 \%$, which was consistent with the findings by Perryman (2003). The ratio (integrated area for total diesel hydrocarbons/ integrated area of internal standard) for the prepared standards and the calculated values for extracted standards values are shown in Table 8. The standard and extracted standard values for the above ratio versus diesel fuel concentration are plotted in Figure 11.

The Gas chromatograms of diesel standards and diesel-extracted standards are presented in Appendix C, Figures C 1 to C 14 and C 15 to C 28, respectively. 
TABLE 8. VALUES FOR GAS CHROMATOGRAM CALIBRATION CURVE FOR DIESEL FUEL STANDARDS

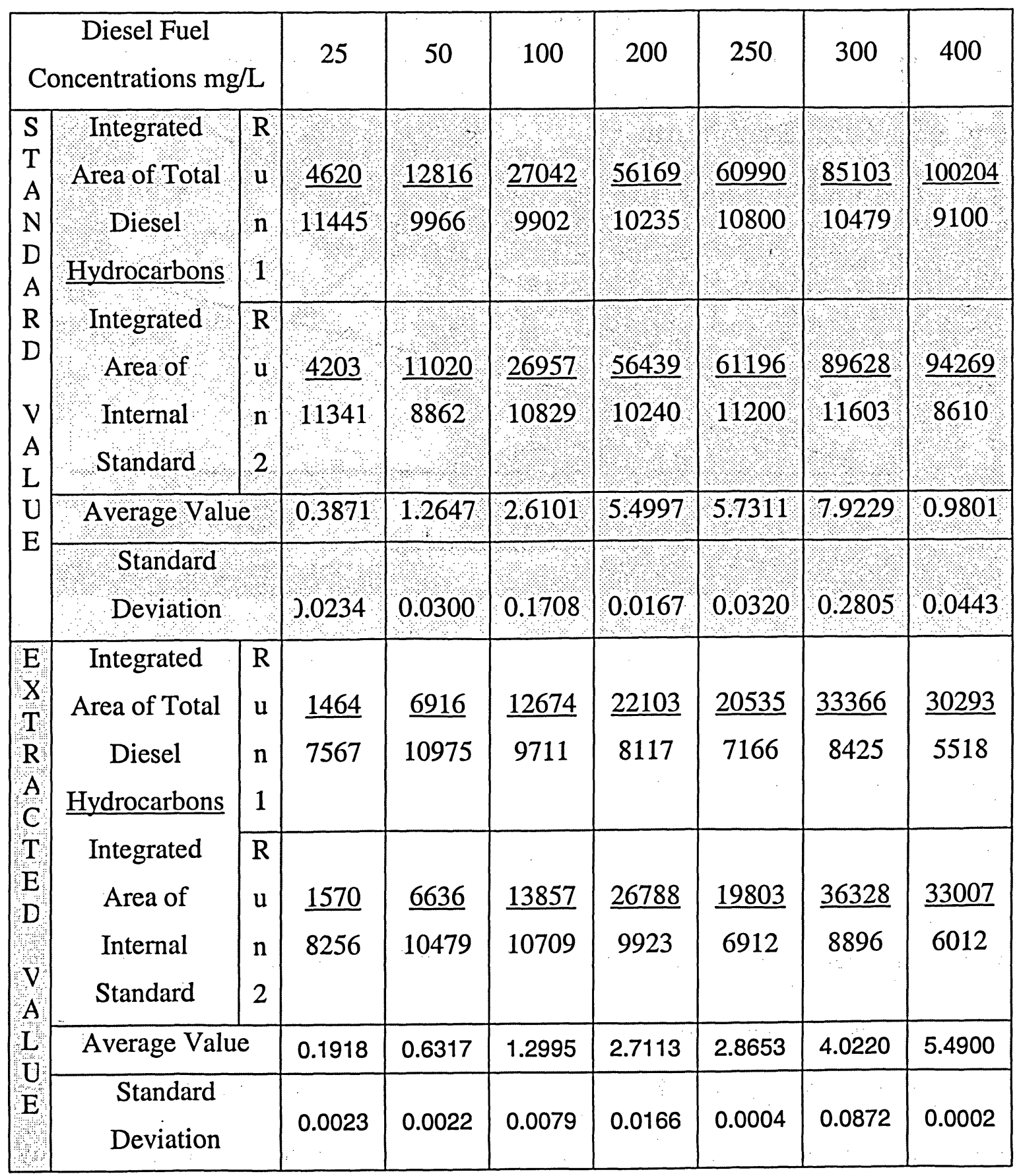




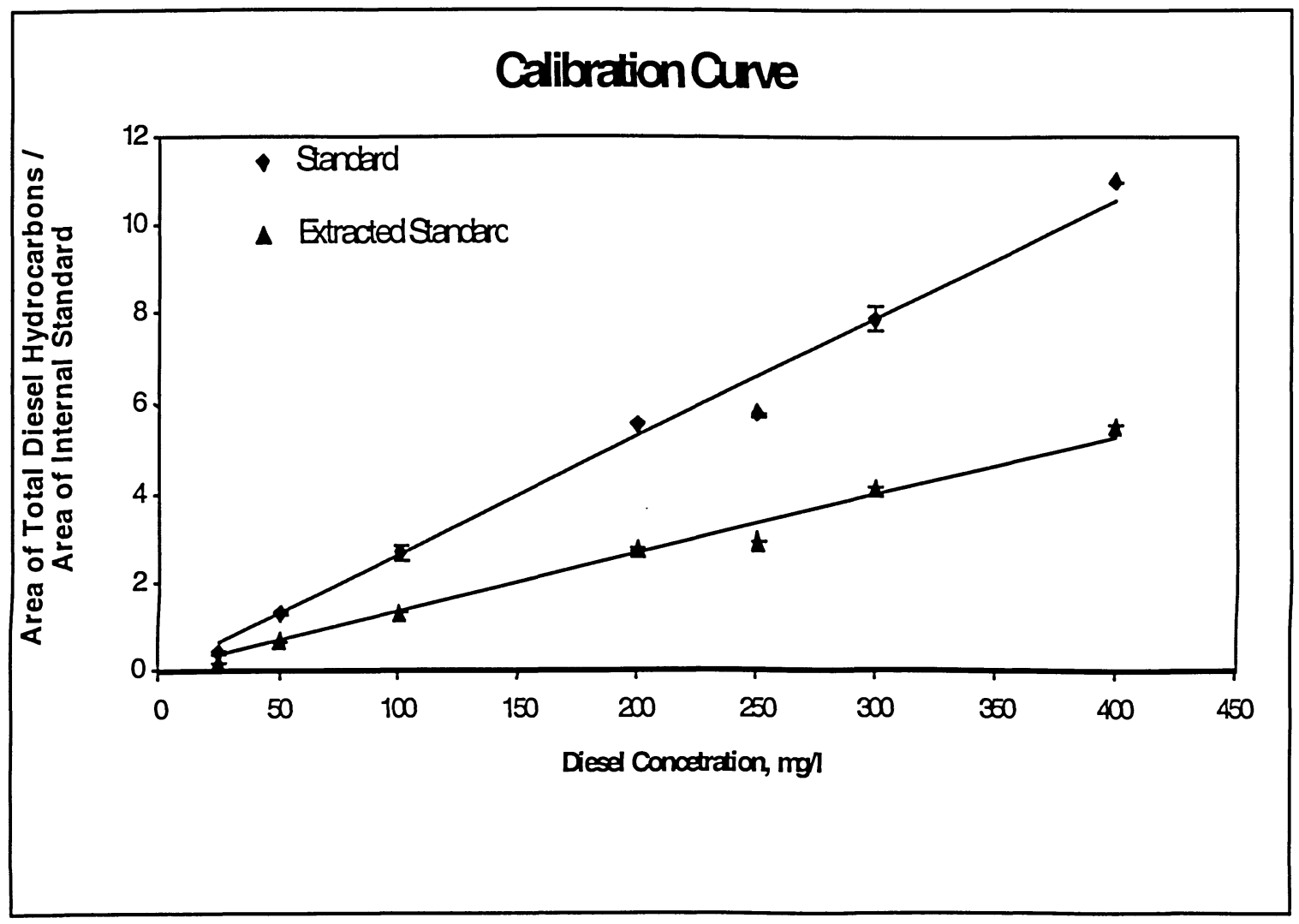

\section{Dissolved Oxygen Meter}

Dissolved oxygen (DO) concentration in the water was measured using an YSI Model 58 Oxygen meter in combination with the YSI model 5739 dissolved oxygen probe. The YSI models have demonstrated to be reliable for measurement of oxygen concentration in water (Alvarez-Cuenca, 1979; Bolanos, 2000). Temperature was measured in the range $29^{\circ} \mathrm{C}-31^{\circ} \mathrm{C}$ with $0.1^{\circ} \mathrm{C}$ resolutions. Clark-type membranes were used during this study because they isolate the sensor elements from the environment but allowed oxygen and certain other gases to diffuse through them. 


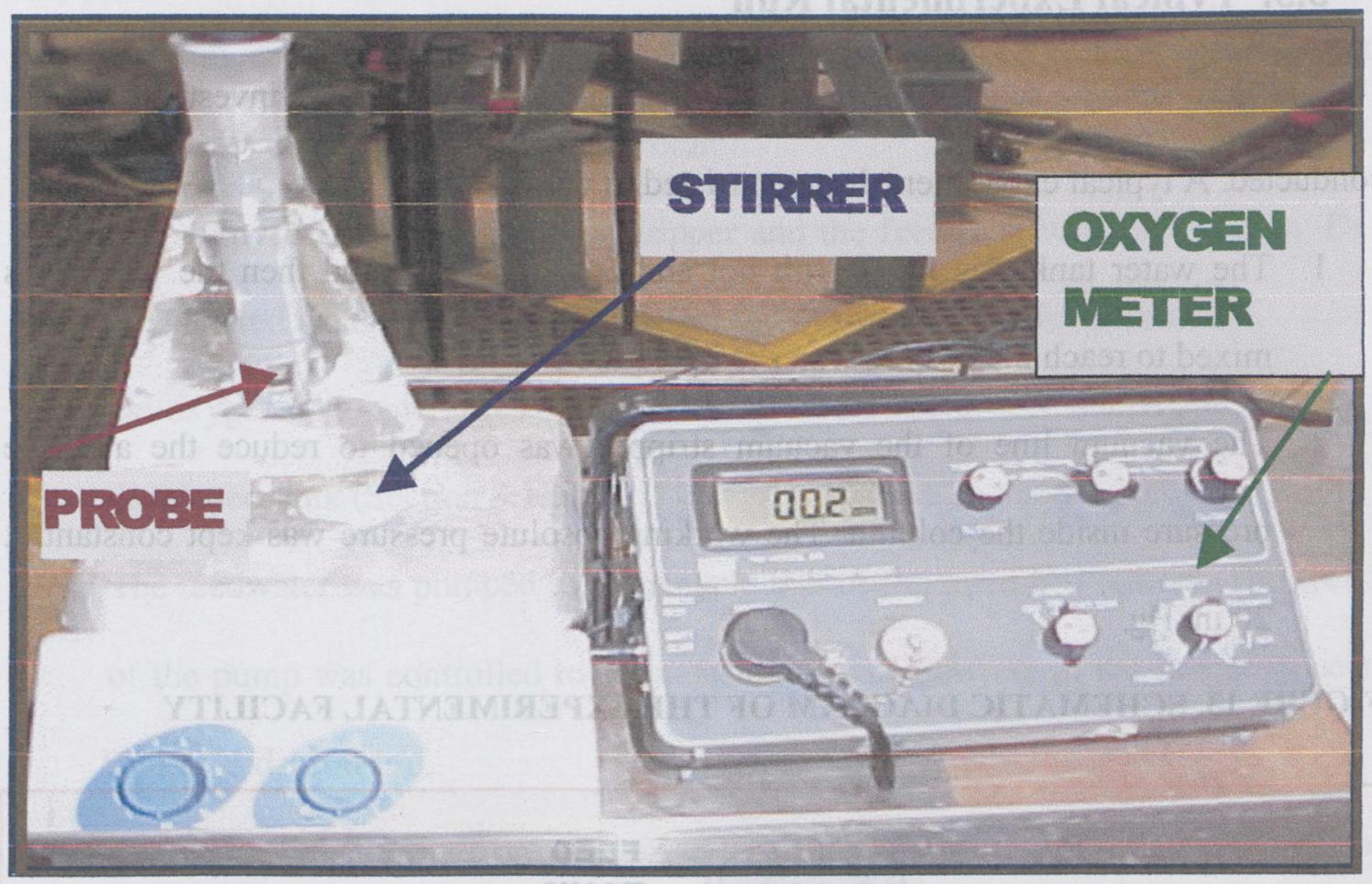

Dissolved Oxygen concentration was directly read in $\mathrm{mg} / \mathrm{L}$ unit (Figure 12 ). In addition, a magnetic stirrer was used to mix the samples and to avoid oxygen depleted layers of the sample on the membrane surface, allowing greater accuracy in the measurements. The stirrer speed was maintained constant at setting $6(\sim 600 \mathrm{rpm})$ during all experimental measurements. Bolanos (2000) suggested that $600 \mathrm{rpm}$ is an optimum speed with less than $2 \%$ variations. The DO meter calibration procedure utilized distilled water preaerated for 30 minutes in order to achieve the equilibrium DO concentration in water at 
the atmospheric pressure. Volume of liquid samples was $1 \mathrm{~L}$ and was kept constant throughout the study.

\subsection{Typical Experimental Run}

Figure 13 shows a schematic of the experimental facility where this investigation was conducted. A typical experimental run consisted of the following steps:

1. The water tank was filled with hot and cold tap water and then the water was mixed to reach the desired water temperature $30 \pm 1{ }^{\circ} \mathrm{C}$.

2. The vacuum line of the vacuum stripper was opened to reduce the absolute pressure inside the column. The working absolute pressure was kept constant at 20 in. $\mathrm{Hg}$.

FIGURE 13. SCHEMATIC DIAGRAM OF THE EXPERIMENTAL FACILITY

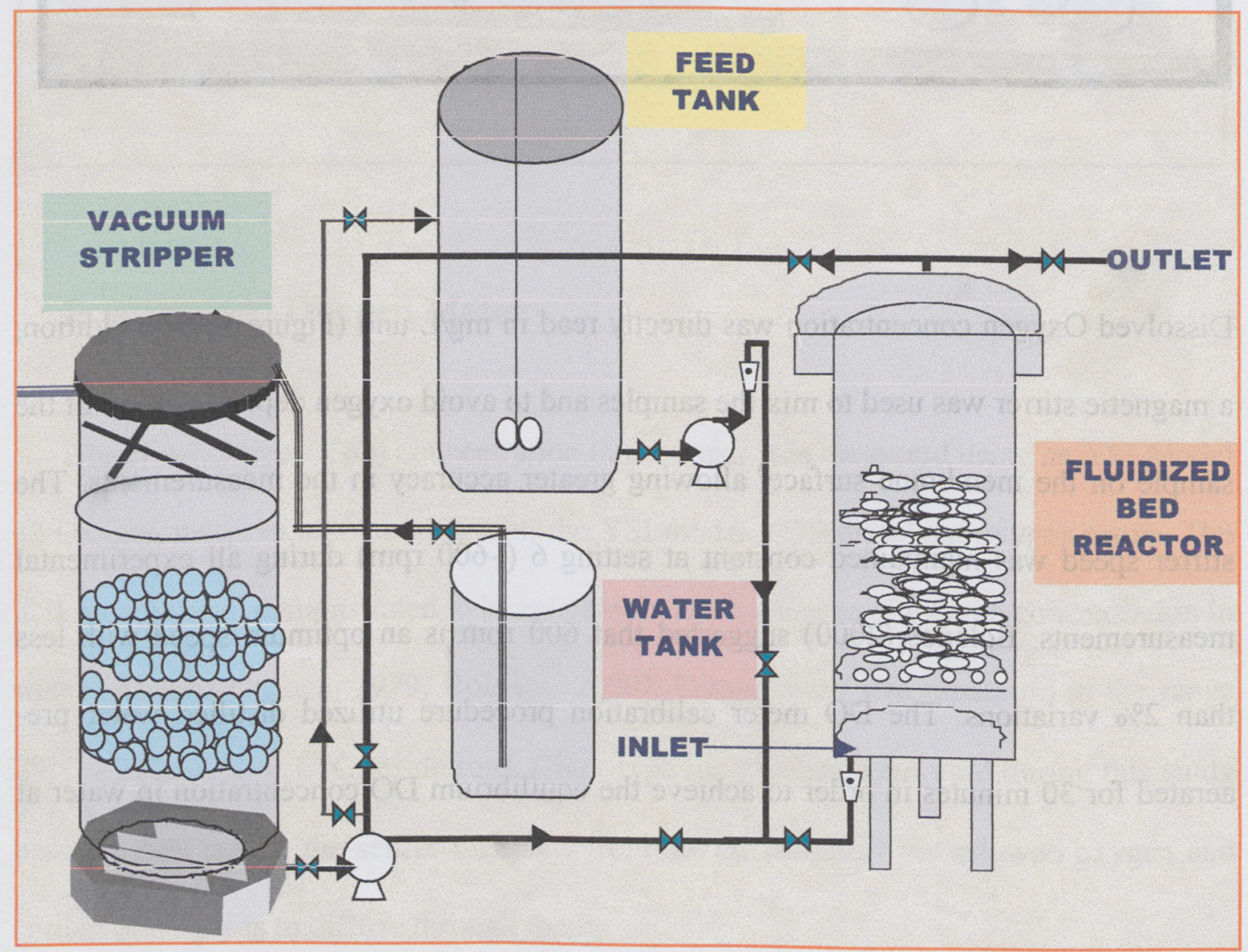


3. The valve connecting the vacuum stripper with the water tank was switched on so that the vacuum created in vacuum stripper drew water from water tank into the vacuum stripper. In the vacuum stripper the water is de-oxygenated and collected in a reservoir at the bottom of the column.

4. The pump between the vacuum stripper and the feed tank was switched on. Deoxygenated water from vacuum stripper was pumped to the feed tank

5. De-oxygenated water, diesel fuel, nutrients and buffers were added and mixed in the closed-tank (Section 3.1.B.).

6. The feedwater was pumped to the recycle line of fluidized bed reactor. The speed of the pump was controlled to set a desired liquid flowrate in the range between $75 \mathrm{~L} / \mathrm{d}$ and $1200 \mathrm{~L} / \mathrm{d}$.

7. The water left the fluidized bed column through the weir that is located $145 \mathrm{~cm}$ from the diffuser and flows partly out and partly in the recycle line. In order to achieve the desired removal rates, flow recycling was employed. In these experiments the ratio of recycle flow to forward flow (recycle ratio) was controlled at $1537 ; 1158 ; 761 ; 380 ; 189$ and 94 .

8. Samples were taken at the sampling ports shown in Section 3.1.F. and analytical analyses were done according to Section 3.2. 


\subsection{Experimental Program}

The main purpose of this research was to investigate the performance of the AFBR using GAC as attachment medium for microorganisms. The AFBR was operated in batch mode (for 65 days) to achieve acclimation of biomass and biofilm formation. After that, the GAC AFBR was operated continuously to observe the efficiency of biodegradation of diesel. The hydraulic residence time and the organic loading rate (OLR) were varied, while maintaining constant influent diesel fuel concentration in the reactor. The organic loading rate was a parameter used to illustrate the efficiency of fluidized bed reactors applied in wastewater treatment and accounts for both the influent flow rate and the influent substrate concentration. (Garcia-Calderon et al. 1998):

$$
\text { OLR }=\frac{Q_{i}\left(\mathrm{~m}^{3} / \mathrm{d}\right) S_{i}\left(\mathrm{~kg} / \mathrm{m}^{3}\right)}{V\left(\mathrm{~m}^{3}\right)}=\mathrm{kg} / \mathrm{m}^{3} \cdot \mathrm{d}
$$

Steady state conditions were determined statistically when the coefficient of variance in the reactor's performance was less than $5 \%$, measured as effluent COD. The experimental program consisted of four phases, which are described in the following sections. 


\subsubsection{Phase I}

During Phase I (day 1 to 36), the influent diesel fuel concentration in the AFB Reactor was $100 \mathrm{mg} / \mathrm{L}$ while organic loading rate and HRT varied. The organic loading rate increased with a decrease in HRT. Table 9 summarizes the operating conditions for the anaerobic reactor during Phase I of this study.

TABLE 9. OPERATING PARAMETERS FOR THE ANAEROBIC FLUIDIZED BED REACTOR DURING PHASE I

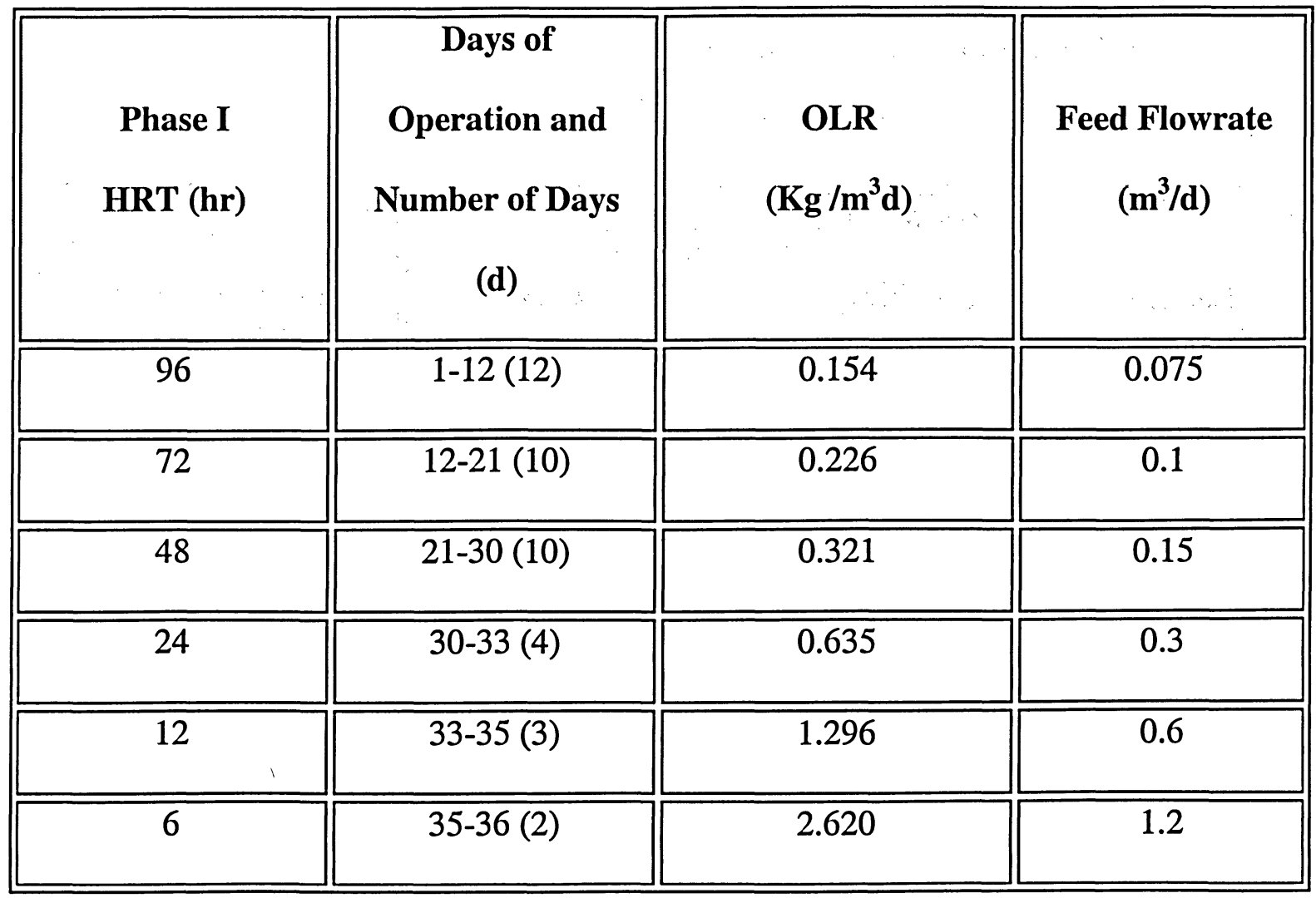




\subsubsection{Phase II}

During Phase II (day 37 to 69), the influent diesel concentration was constant at 200 $\mathrm{mg} / \mathrm{L}$ while organic loading rate and HRT changed. The GAC-AFBR received an increase in organic loading rate while reducing the HRT as seen in Table 10. After the performance stabilized at each HRT, operation at the new HRT started. The reactor was considered to be at steady state condition when diesel was removed with no large fluctuations in effluent concentrations

TABLE 10. OPERATING PARAMETERS FOR THE ANAEROBIC FLUIDIZED BED REACTOR DURING PHASE II

\begin{tabular}{||c||c|c|c||}
\hline Phase II & $\begin{array}{c}\text { Days of Operation } \\
\text { and Number of }\end{array}$ & OLR & Feed Flowrate \\
HRT (hr) & Days & $\left(\mathbf{K g} / \mathbf{m}^{3} \mathbf{d}\right)$ & \\
& $(\mathbf{d})$ & & \\
\hline 96 & $37-48(12)$ & 0.224 & 0.075 \\
\hline \hline 72 & $48-57(10)$ & 0.341 & 0.1 \\
\hline \hline 48 & $57-63(7)$ & 0.451 & 0.15 \\
\hline \hline 24 & $63-66(4)$ & 0.893 & 0.3 \\
\hline \hline 12 & $66-68(3)$ & 1.626 & 1.2 \\
\hline \hline 6 & $68-69(2)$ & 3.576 & \\
\hline
\end{tabular}




\subsubsection{Phase III}

During Phase III (day 70 to 102), GAC-AFBR received an increase in organic loading rate, reducing the HRT while maintaining a constant influent diesel fuel concentration of $300 \mathrm{mg} / \mathrm{L}$. Table 11 summarizes the operating conditions for the anaerobic reactor during Phase III of this study.

TABLE 11. OPERATING PARAMETERS FOR THE ANAEROBIC FLUIDIZED BED REACTOR DURING PHASE III

\begin{tabular}{|c|c|c|c|}
\hline $\begin{array}{l}\text { Phase III } \\
\text { HRT (hr) }\end{array}$ & $\begin{array}{l}\text { Days of } \\
\text { Operation and } \\
\text { Number of Days } \\
\text { (d) }\end{array}$ & $\begin{array}{c}\text { OLR } \\
\left(\mathrm{Kg} / \mathrm{m}^{3} \mathrm{~d}\right)\end{array}$ & $\begin{array}{l}\text { Feed Flowrate } \\
\qquad\left(\mathrm{m}^{3} / \mathrm{d}\right)\end{array}$ \\
\hline$\overline{96}$ & $70-81(12)$ & 0.435 & 0.075 \\
\hline 72 & $81-90(10)$ & 0.577 & 0.1 \\
\hline 48 & $90-96(7)$ & 0.825 & 0.15 \\
\hline 24 & 96-99(4) & 1.688 & 0.3 \\
\hline 12 & $99-101(3)$ & 3.376 & 0.6 \\
\hline 6 & $101-102(2)$ & 6.396 & 1.2 \\
\hline
\end{tabular}




\subsubsection{Phase IV}

Phase IV (day 103 to 135) is a repetition of Phase I after nearly 2 months. The purpose was to verify if variations in reactor performance were attributed to either the lowering of the HRT or to acclimation of the biomass. Table 12 summarizes the operating conditions for the AFBR during Phase IV of this study.

TABLE 12. OPERATING PARAMETERS FOR THE ANAEROBIC FLUIDIZED BED REACTOR DURING PHASE IV

\begin{tabular}{|c|c|c|c|}
\hline $\begin{array}{l}\text { Phase IV } \\
\text { HRT (hr) }\end{array}$ & $\begin{array}{c}\text { Days of } \\
\text { Operation and } \\
\text { Number of Days } \\
\text { (d) }\end{array}$ & $\begin{array}{c}\text { OLR } \\
\left(\mathrm{Kg} / \mathrm{m}^{3} \mathrm{~d}\right)\end{array}$ & $\begin{array}{c}\text { Feed Flowrate } \\
(\mathrm{m} 3 / \mathrm{d})\end{array}$ \\
\hline$\overline{96}$ & $103-114(12)$ & 0.162 & 0.075 \\
\hline 72 & $114-123(10)$ & 0.215 & 0.1 \\
\hline 48 & $123-129(7)$ & 0.310 & 0.15 \\
\hline 24 & $\overline{129-132(4)}$ & 0.637 & 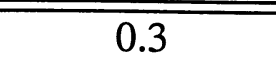 \\
\hline 12 & $132-134(3)$ & 1.264 & 0.6 \\
\hline 6 & $134-135(2)$ & 2.648 & 1.2 \\
\hline
\end{tabular}




\section{CHAPTER 4. RESULTS AND DISCUSSION}

Several experiments were performed to study the anaerobic degradation of TPH (total petroleum hydrocarbons)-diesel fuel in the fluidized bed reactor for various diesel fuel influent concentrations under different operational conditions. Evaluation of gas chromatograms and COD results in the following sections will assess the reactor's diesel removal efficiency and COD removal capability.

\subsection{Evaluations of Gas Chromatogram Results}

The wastewater samples were taken at three sampling ports in the AFBR (see section 3.1.E.). The samples for each run were extracted using methods outlined in section 3.2.D. and prepared for GC/MS analysis. To determine the average value and to reduce experimental errors two samples were taken from each sampling point. The values of diesel fuel concentrations in $(\mathrm{mg} / \mathrm{L})$ for each experimental run taken by GC-MS have been shown in Appendix D, Table D 1 and Table D 2. Figure 14 shows that diesel fuel effluent concentration was as low as $23.11 \mathrm{mg} / \mathrm{L}$ for hydraulic residence time (HRT) of 96 hours. In addition for a HRT of 6 hours diesel fuel effluent concentration was 43.08$\mathrm{mg} / \mathrm{L}$. Diesel fuel effluent concentrations increased gradually when the HRT decreased. Diesel removal efficiency in Phase I was $58.6 \%$ for HRT of 6 hours. Diesel removal efficiency increased up to $78.0 \%$ when the HRT increased to 96 hours. The diesel fuel concentration in the effluent meets the Groundwater Standard (Level II) even at very short HRT of 6 hours. The low diesel fuel concentrations at the midpoint sampling port show that most of diesel fuel degradation had taken place in the zone between the distributor and the midpoint sampling port (located $45 \mathrm{~cm}$ above the distributor). This is 
an indication that most of the anaerobic degrading diesel fuel microorganisms attached to the GAC particles are located in this zone of AFBR.

FIGURE 14. DIESEL FUEL CONCENTRATION MEASURED BY GC-MS AT VARIOUS POINTS, PHASE I (DIESEL FUEL INFLUENT $100 \mathrm{mg} / \mathrm{L}$ )

PHASE I

Diesel Fuel Influent 100 mg/L

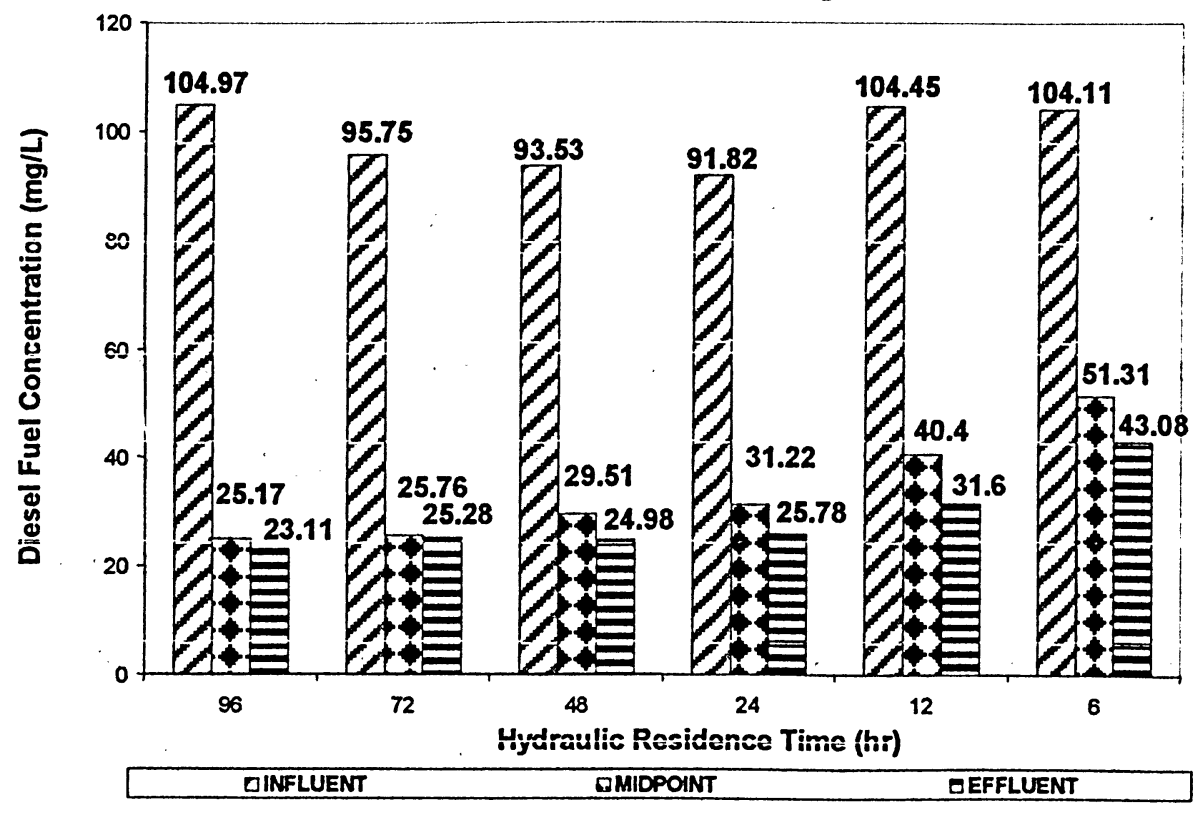

PHASE I

Diesel Fuel Influent $100 \mathrm{mg} / \mathrm{L}$

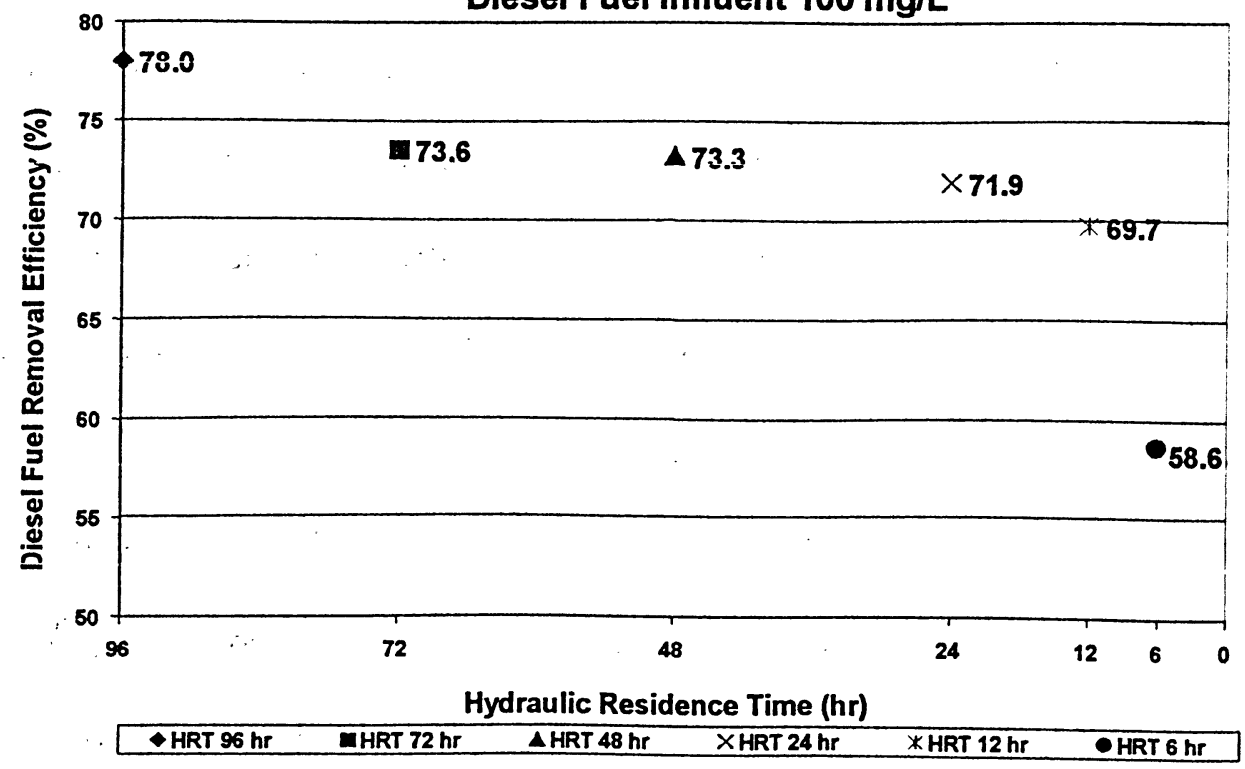


Figure 15 shows that diesel fuel effluent concentration increased from $23.31 \mathrm{mg} / \mathrm{L}$ for HRT of 96 hours to $38.7 \mathrm{mg} / \mathrm{L}$ for HRT of 6 hours. Diesel removal efficiency in Phase II was $80.9 \%$ for HRT of 6 hours and increasèd up to $88: 6 \%$ for HRT of 96 hours. Figure 15 illustrates that the effluent for HRT as low as 6: hours met the levels for Groundwater Standards (level II) Moderate Sensitivity Sites.

FIGURE 15. DIESEL FUEL CONCENTRATION MEASURED BY GC-MS AT VARIOUS POINTS, PHASE II (DIESEL FUEL INFLUENT $200 \mathrm{mg} / \mathrm{L}$ )

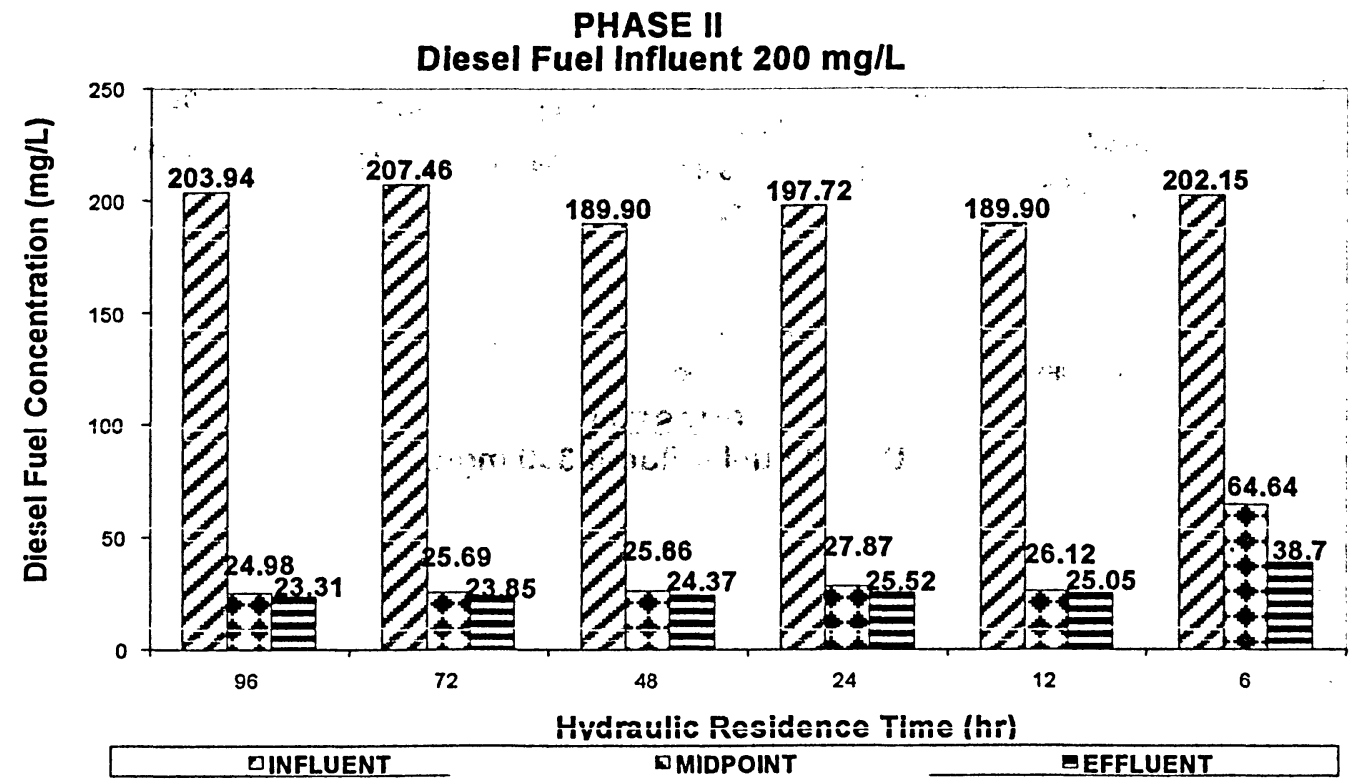

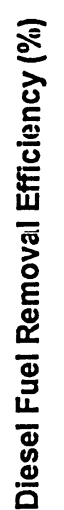

\section{PHASE II}

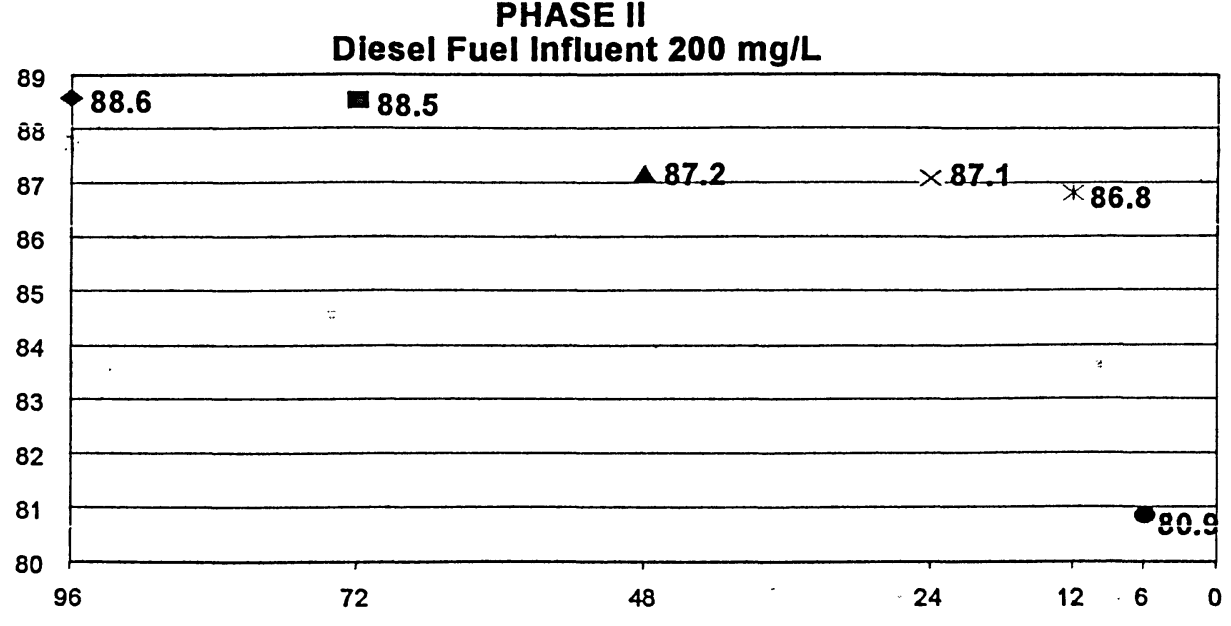

Hydraulic Residence Time (hr)

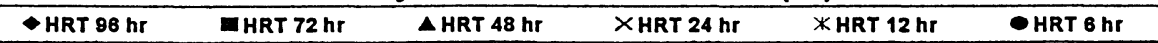


FIGURE 16. DIESEL FUEL CONCENTRATION MEASURED BY GC-MS AT VARIOUS POINTS, PHASE III (DIESEL FUEL INFLUENT $300 \mathrm{mg} / \mathrm{L}$ )

PHASE III

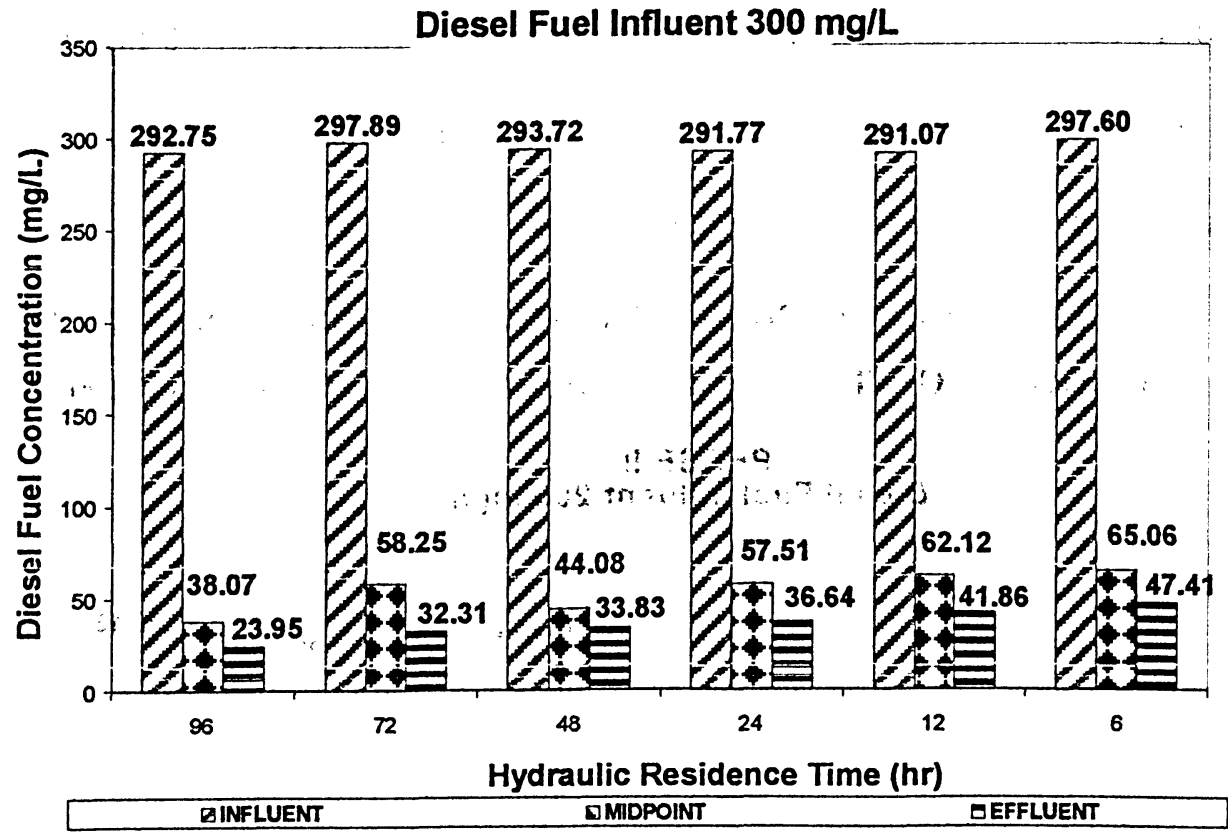

PHASE III

Diesel Fuel Influent $300 \mathrm{mg} / \mathrm{L}$

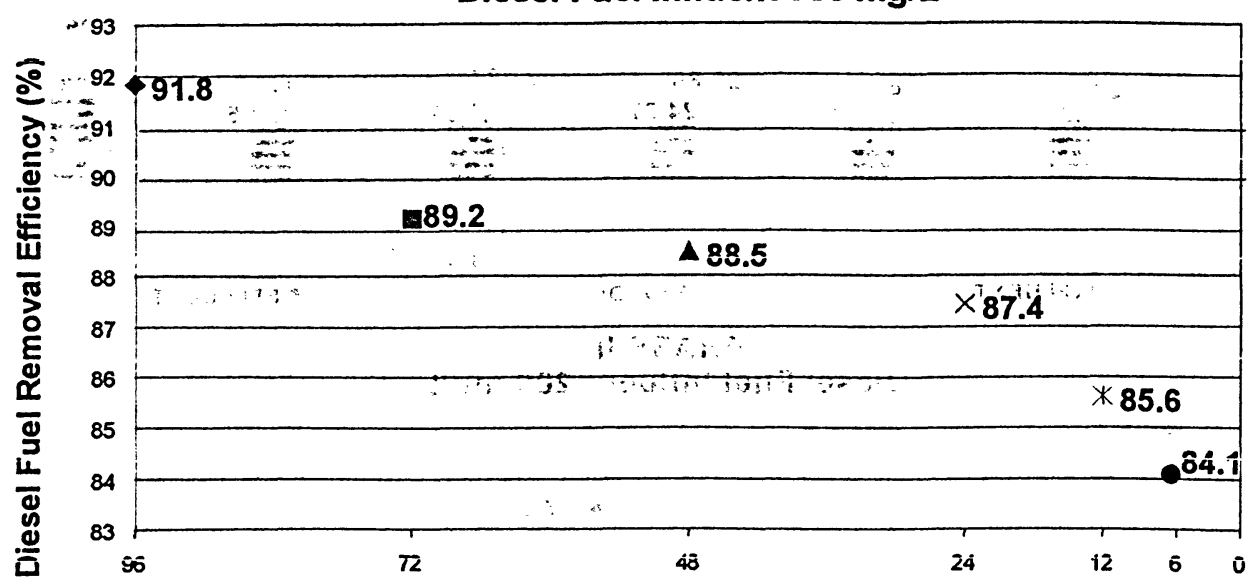

Hydraulic Residence Time (hr)

\begin{tabular}{|c|c|c|c|c|c|}
\hline HRT $96 \mathrm{hr}$ & DHRT $72 \mathrm{hr}$ & $\triangle H R T 48 \mathrm{hr}$ & $\times$ HRT $24 \mathrm{hr}$ & * HRT $12 \mathrm{hr}$ & HRT $6 \mathrm{hr}$ \\
\hline
\end{tabular}

During Phase III (Figure 16) diesel fuel effluent concentration was $47.41 \mathrm{mg} / \mathrm{L}$ for HRT of 6 hours and decreased up to $23.95 \mathrm{mg} / \mathrm{L}$ during the increase in HRT to 96 hours. Figure 16 shows that diesel removal efficiency increased from $84.1 \%$ at HRT of 6 hours 
to $91.8 \%$ at HRT of 96 hours. It can be noted that effluent diesel fuel concentrations were maintained at less than $50 \mathrm{mg} / \mathrm{L}$ even for $\mathrm{HRT}$ as low as 6 hours. Gas chromatography results for Phase I, Phase II and Phase III showed that the increase of the HRT increased the diesel fuel removal efficiency. This pattern noticed (Figure 14-16) was due to a higher utilization of diesel hydrocarbons by the anaerobic microorganisms at a higher residence time of diesel hydrocarbons in contact with them. In addition, it was noticed that an increase in influent diesel fuel concentration was accompanied by an increase in the diesel fuel removal efficiency. This was due to fact that more dissolved diesel fuel concentration in wastewater was available to utilize by microorganisms.

While diesel fuel influent concentration doubled and tripled from Phase I-III, the diesel fuel effluent concentration increased slightly. For example, at HRT of 96 hours effluent concentration increased from $23.11 \mathrm{mg} / \mathrm{L}$ (Phase I), $23.31 \mathrm{mg} / \mathrm{L}$ (Phase II) to $23.95 \mathrm{mg} / \mathrm{L}$ (Phase III). It can be seen from the data in Figures 14 to 16 that diesel fuel concentration gradients across the reactor existed during this study. This is significant since effluent diesel fuel concentrations from the anaerobic fluidized bed reactor were always $<50$ $\mathrm{mg} / \mathrm{L}$ while the diesel fuel influent concentrations in the reactor were 100, 200 and 300 $\mathrm{mg} / \mathrm{L}$. These results are important and show that AFBR was effective in achieving level II groundwater standards for HRT as low as 6 hours.

Figure 17 shows that at the same HRT, the efficiency of diesel fuel removal increased sharply from Phase I to Phase II, while reaching a constant level of less than $4 \%$ variation for Phase II to Phase III. This indicated that the maximum diesel fuel uptake rate is reàched at Phase II (diesel fuel influent concentration $200 \mathrm{mg} / \mathrm{L}$ ). For example, the efficiency of diesel fuel removal in Phase I was $58.6 \%$, in Phase II was $80.86 \%$ and in 
Phase III was $84.1 \%$ at HRT of 6 hours. The diesel removal efficiency exceeded $58.6 \%$ throughout the whole experiment (Figure17).

FIGURE 17. DIESEL REMOVAL EFFICIENCY PROFILE FOR PHASE I, PHASE II AND PHASE III

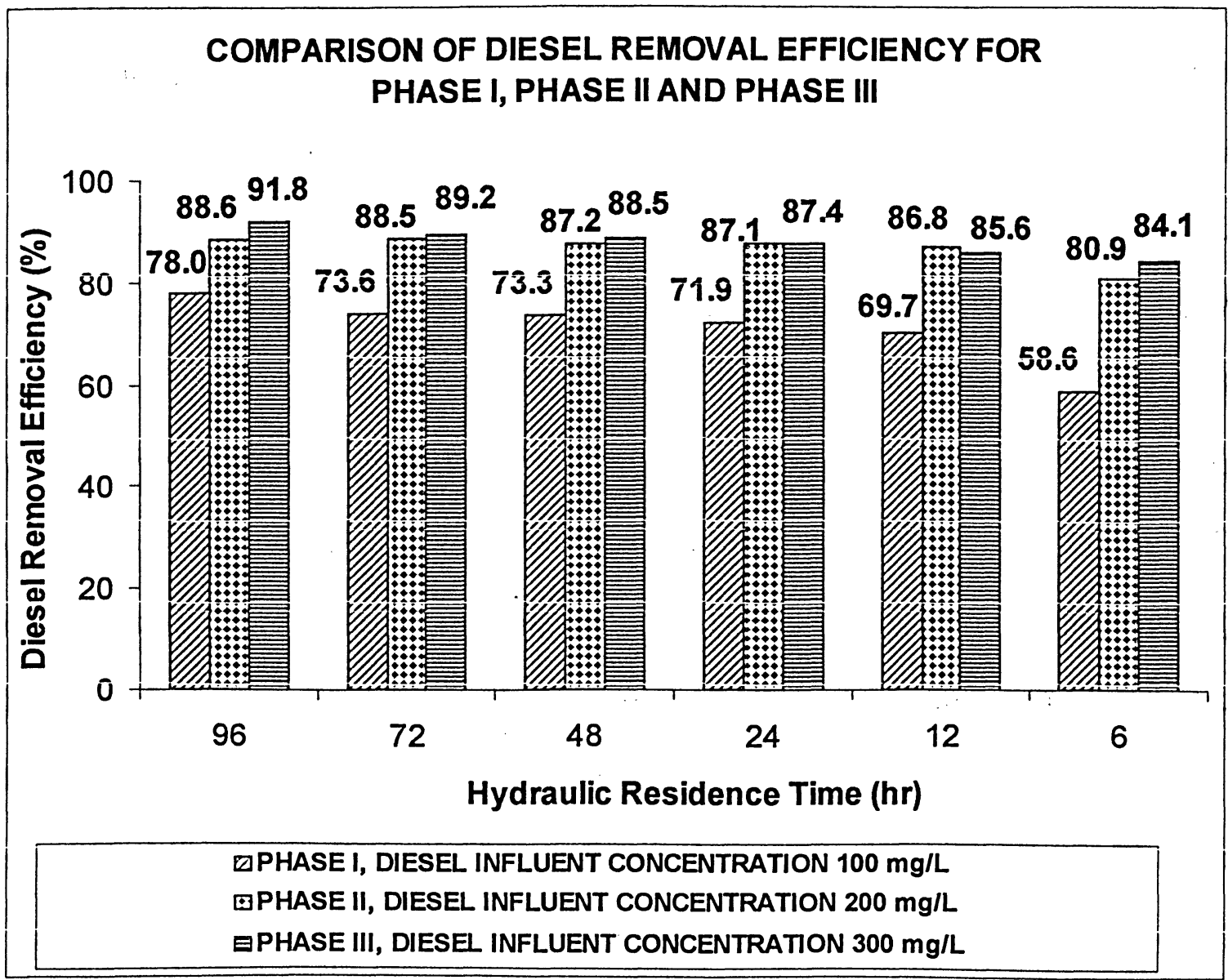

Phase IV was a repetition of Phase I after nearly 2 months (Figure 18). Diesel fuel effluent concentration was $34.8 \mathrm{mg} / \mathrm{L}$ for HRT of 6 hours. The effluent diesel fuel concentration decreased when HRT was increased. Figure 18 shows that the HRT 
significantly affects the diesel removal efficiency. For example, diesel removal efficiency increased from $61.9 \%$ for HRT of 6 hours to $77.8 \%$ for HRT of 96 hours.

FIGURE 18. DIESEL FUEL CONCENTRATION MEASURED BY GC-MS AT VARIOUS POINTS, PHASE IV (DIESEL FUEL INFLUENT $100 \mathrm{mg} / \mathrm{L}$ )

PHASE IV

Diesel Fuel Influent 100 mg/L

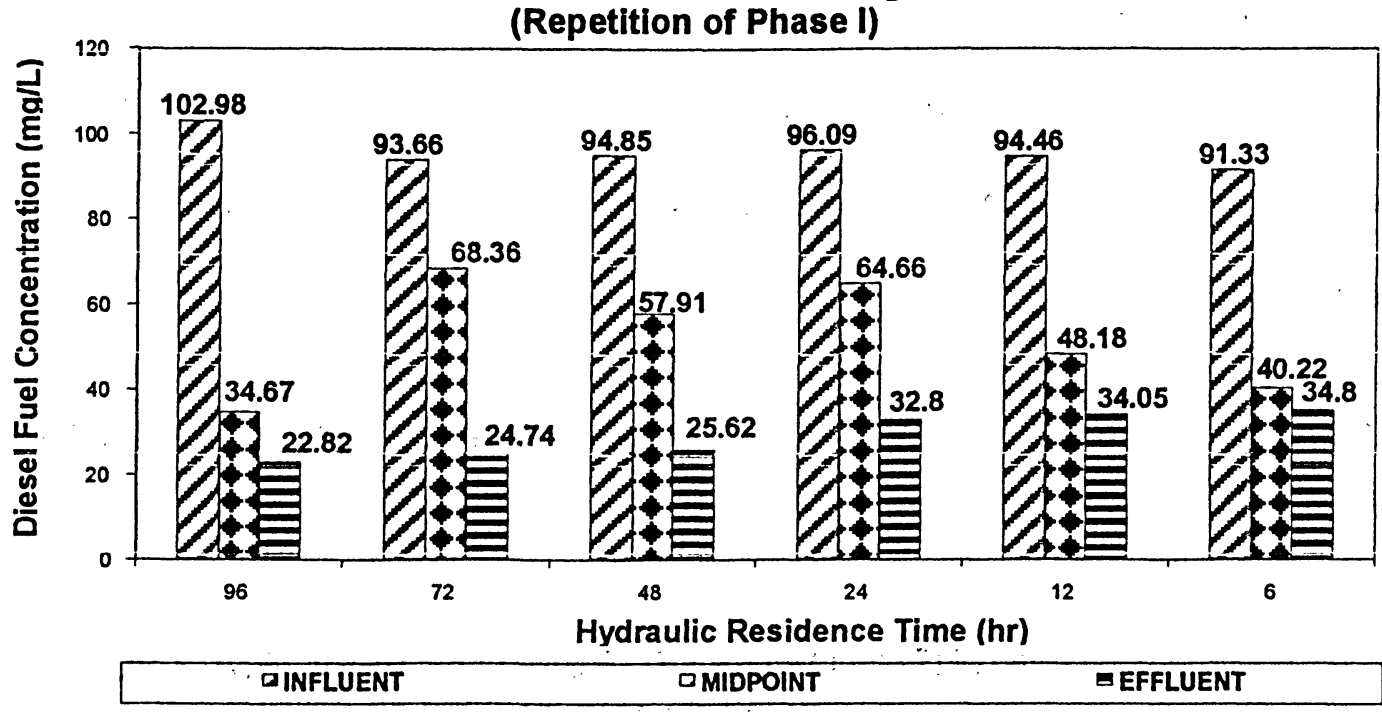

PHASE IV

Diesel Fuel Influent $100 \mathrm{mg} / \mathrm{L}$

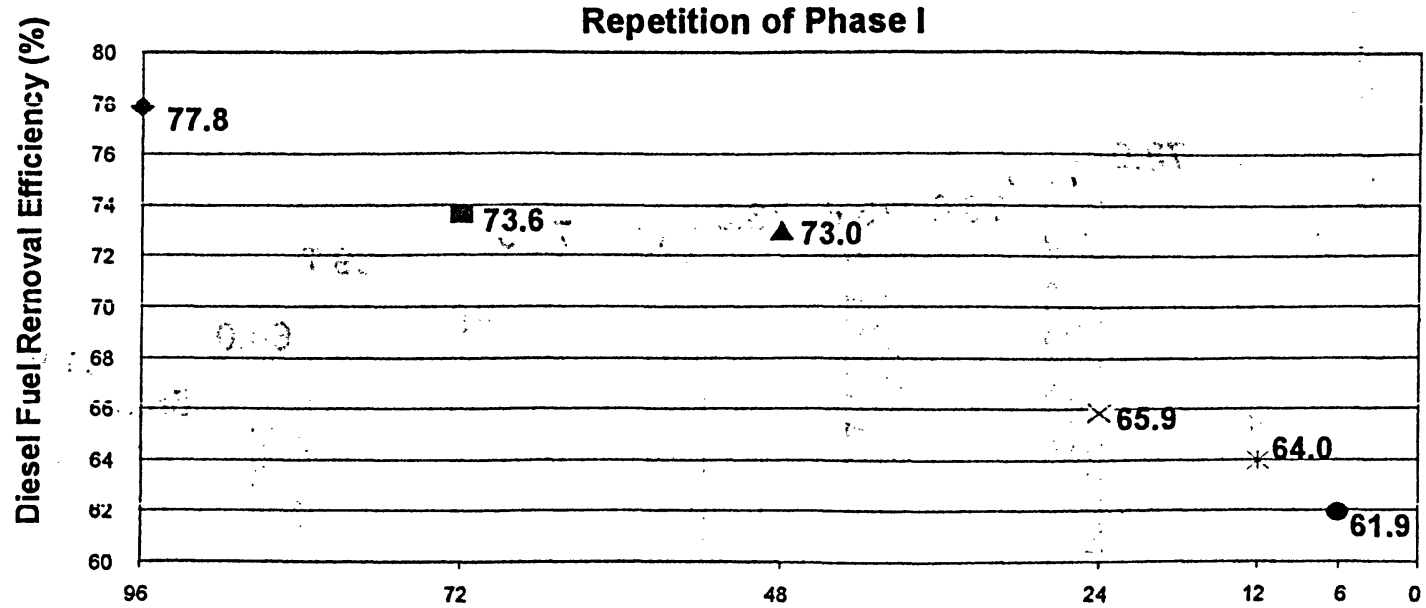

Hydraulic Residence Time (hr)

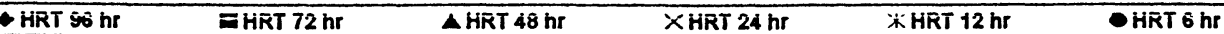


It was noticed that diesel fuel concentration decreased much more in the first $45 \mathrm{~cm}$ from the flow distributor in the Phase I than in the Phase II (see Figure 14 and Figure 18). For example, in Phase I, diesel fuel concentration for HRT of $96 \mathrm{hr}$ at the influent sampling port was $104.97 \mathrm{mg} / \mathrm{L} ; 25.17 \mathrm{mg} / \mathrm{L}$ at the midpoint sampling port and $23.11 \mathrm{mg} / \mathrm{L}$ at the effluent sampling port. While for the same HRT in Phase IV the diesel fuel concentrations were: $102.98 \mathrm{mg} / \mathrm{L}$ at the influent port; $34.67 \mathrm{mg} / \mathrm{L}$ at the midpoint port; $22.82 \mathrm{mg} / \mathrm{L}$ at the effluent port. These results at the midpoint port might be due to the increase in the biofilm thickness during two months period, which causes an increase in the bed height.

FIGURE 19. DIESEL REMOVAL EFFICIENCY PROFILE FOR PHASE I AND PHASE : IV
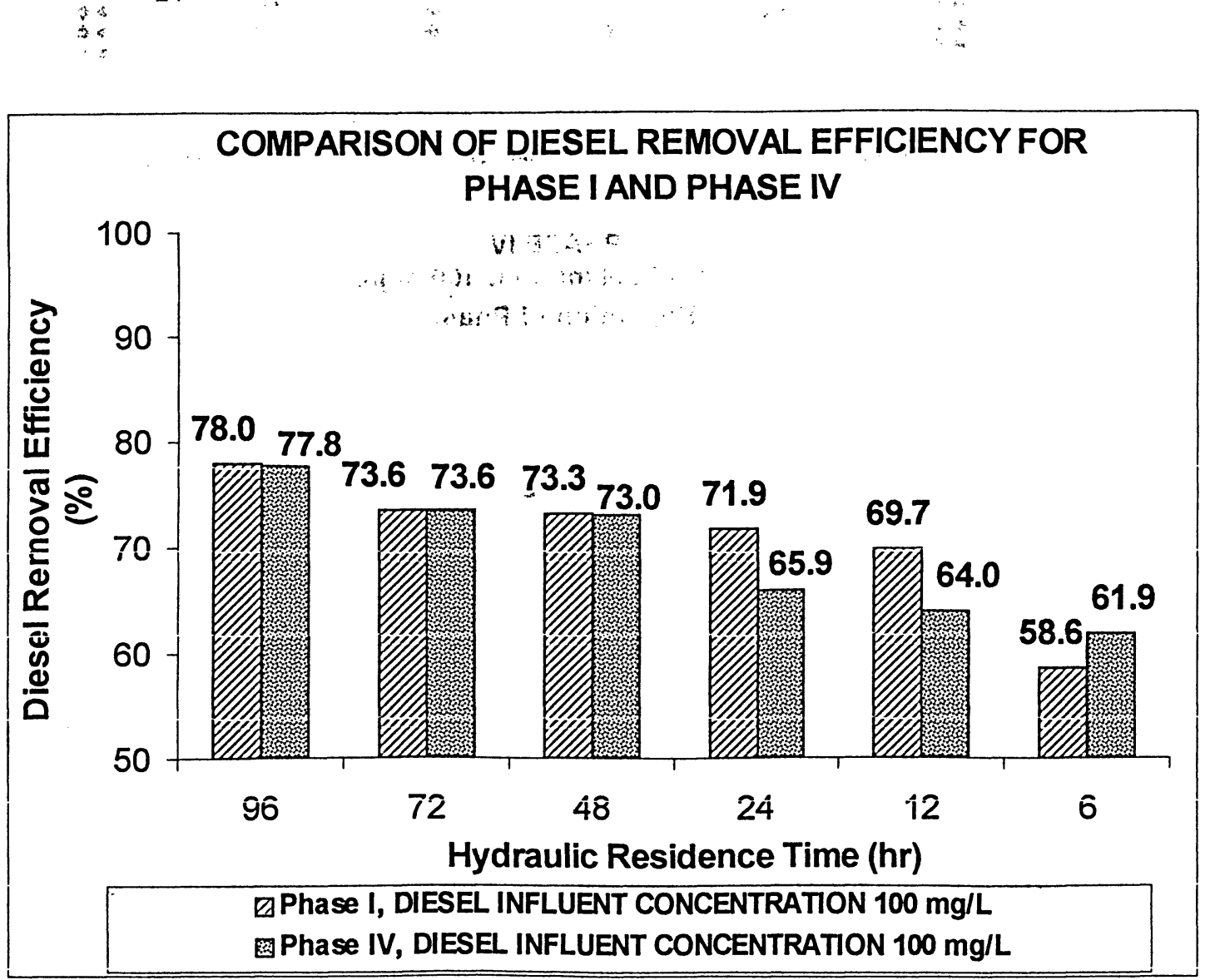
The arising question of this study that whether the variations in reactor performance were due to the lowering of the HRT or due to acclimation of the biomass was answered by comparing results between Phase I and Phase IV (Figure 19). The diesel removal efficiency was $78.0 \%$ in Phase I and $77.8 \%$ in Phase IV for HRT of 96 hour. Also, for HRT of 6 hours, it was $58.6 \%$ in Phase I and $61.9 \%$ in Phase IV. A difference of less than $5 \%$ in diesel removal efficiency was found between Phase I and Phase IV. This is a further indication of reproducibility of data collected in the treatment.

\subsection{Dissolved Oxygen Measurements}

A series of dissolved oxygen (DO) tests were conducted in order to determine the dissolved oxygen concentration in the feedwater. Prior to each dissolved oxygen measurements the calibration procedure of the DO meter was completed (see Section 3.2.H.). The results of dissolved oxygen concentration in water before and after passing the Vacuum Stripper at 20 in. $\mathrm{Hg}$ vacuum are shown in Table 13. The dissolved oxygen at the outlet of vacuum stripper was in the range of $0.1-0.3 \mathrm{mg} / \mathrm{L}$. These low levels of dissolved oxygen concentrations were necessary for creating the proper conditions for the anaerobic biodegradation. Figure 20 illustrates oxygen concentration profile along the flow for the first three experimental runs reported in Table 13. Wastewater samples were taken at the feed tank outlet, the influent of AFBR, the midpoint of AFBR and the outlet of AFBR. These wastewater samples were taken in order to verify that the dissolved oxygen concentration was low as required for anaerobic conditions. 
TABLE 13. DISSOLVED OXYGEN PROFILE AT THE INLET AND AT THE OUTLET OF VACUUM STRIPPER

\begin{tabular}{|c|c|c|c|}
\hline $\begin{array}{c}\text { Experimental } \\
\text { Run }\end{array}$ & \begin{tabular}{|c|} 
DO at the Inlet of Vacuum \\
Stripper \\
$(\mathrm{mg} / \mathrm{L})$
\end{tabular} & $\begin{array}{c}\text { Dissolved Oxygen at } \\
\text { the Outlet of Vacuum } \\
\text { Stripper (mg/L) }\end{array}$ & $\begin{array}{c}\text { Temperature } \\
\left({ }^{\circ} \mathrm{C}\right)\end{array}$ \\
\hline 1 & 7.18 & 0.12 & 29.8 \\
\hline 2 & 7.51 & 0.21 & 30.9 \\
\hline 3 & 7.89 & 0.23 & 30.2 \\
\hline 4 & 8.04 & 0.29 & 30.4 \\
\hline 5 & 7.23 & 0.14 & 29.7 \\
\hline 6 & 7.83 & 0.12 & 29.8 \\
\hline 7 & 7.17 & 0.21 & 30.9 \\
\hline 8 & 7.78 & 0.23 & 30.2 \\
\hline 9 & 8 & 0.29 & 30.4 \\
\hline 10 & 7.45 & 0.14 & 29.7 \\
\hline 11 & 7.29 & 0.12 & 29.8 \\
\hline 12 & 7.09 & 0.21 & 30.9 \\
\hline 13 & 7.72 & 0.23 & 30.2 \\
\hline 14 & 7.96 & 0.22 & 30.4 \\
\hline 15 & 7.39 & 0.14 & $29: 7$ \\
\hline 16 & 7.44 & 0.12 & 29.8 \\
\hline 17 & 7.21 & 0.11 & 30.9 \\
\hline 18 & 7.67 & 0.11 & 30.8 \\
\hline 19 & 8.04 & 0.29 & 29.4 \\
\hline 20 & 7.72 & 0.14 & 29.9 \\
\hline 21 & 8.02 & 0.23 & 29.7 \\
\hline 22 & 7.98 & 0.2 & 30.5 \\
\hline 23 & 7.56 & 0.26 & 29.3 \\
\hline 24 & 7.42 & 0.13 & 30.6 \\
\hline
\end{tabular}


FIGURE 20. THE DISSOLVED OXYGEN PROFILE AT VARIOUS POINTS IN THE EXPERIMENTAL SYSTEM

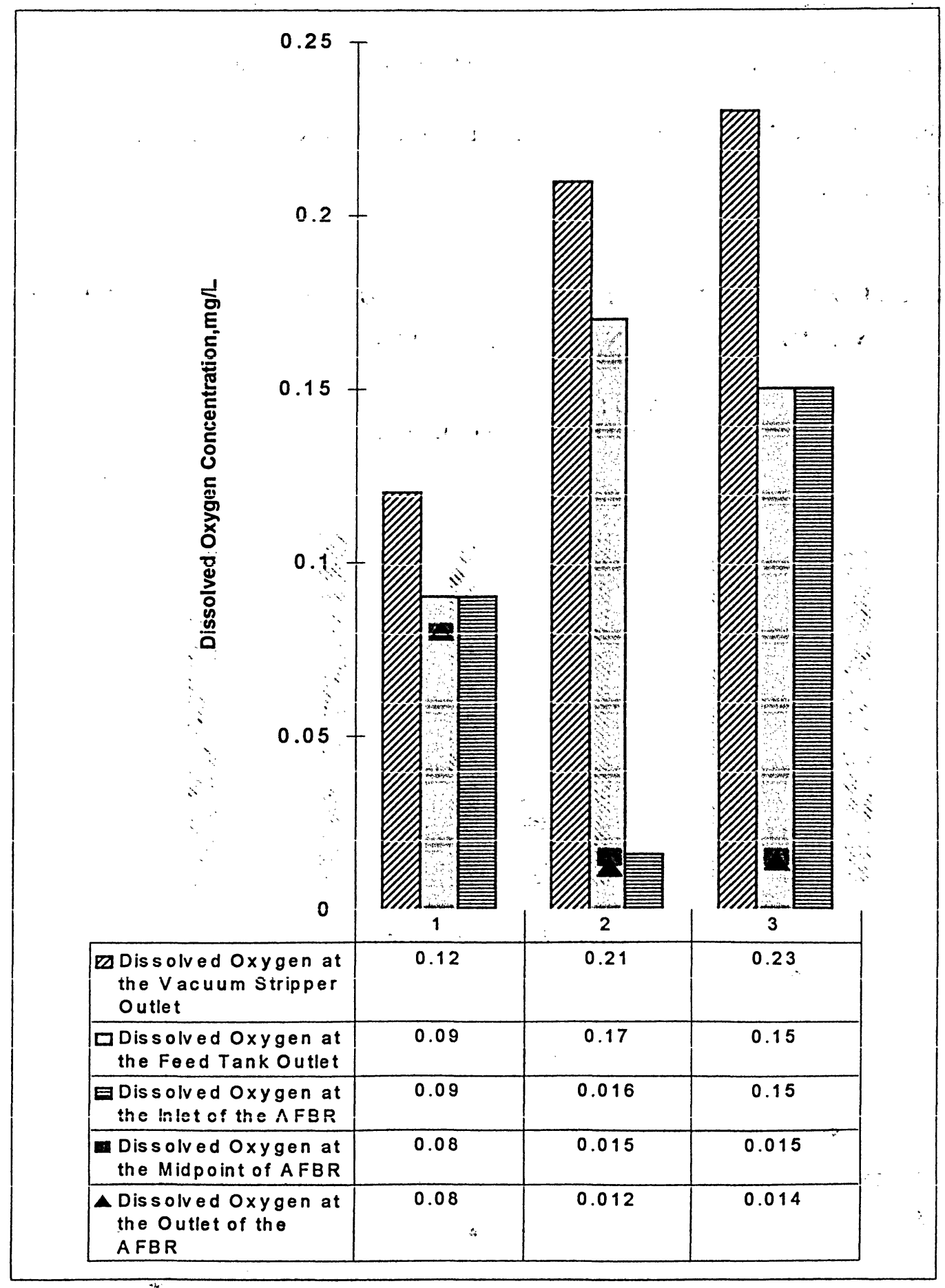

Figure 20 also verifies that during these experiments the dissolved oxygen concentrations remained in the range of $0.1-0.3 \mathrm{mg} / \mathrm{L}$. 


\subsection{Evaluation of Chemical Oxygen Demand Results}

A series of chemical oxygen demand tests were conducted in order to assess the amount of organic matter that is present in feedwater. The feedwater samples were taken at three sampling ports in the AFBR (see section 3.1.E.) and prepared according to the method outlined in section 3.2.B.

\section{FIGURE 21. COD CONCENTRATIONS AND THE COD REMOVAL PERCENTAGE AT VARIOUS POINTS IN THE AFBR, PHASE I}

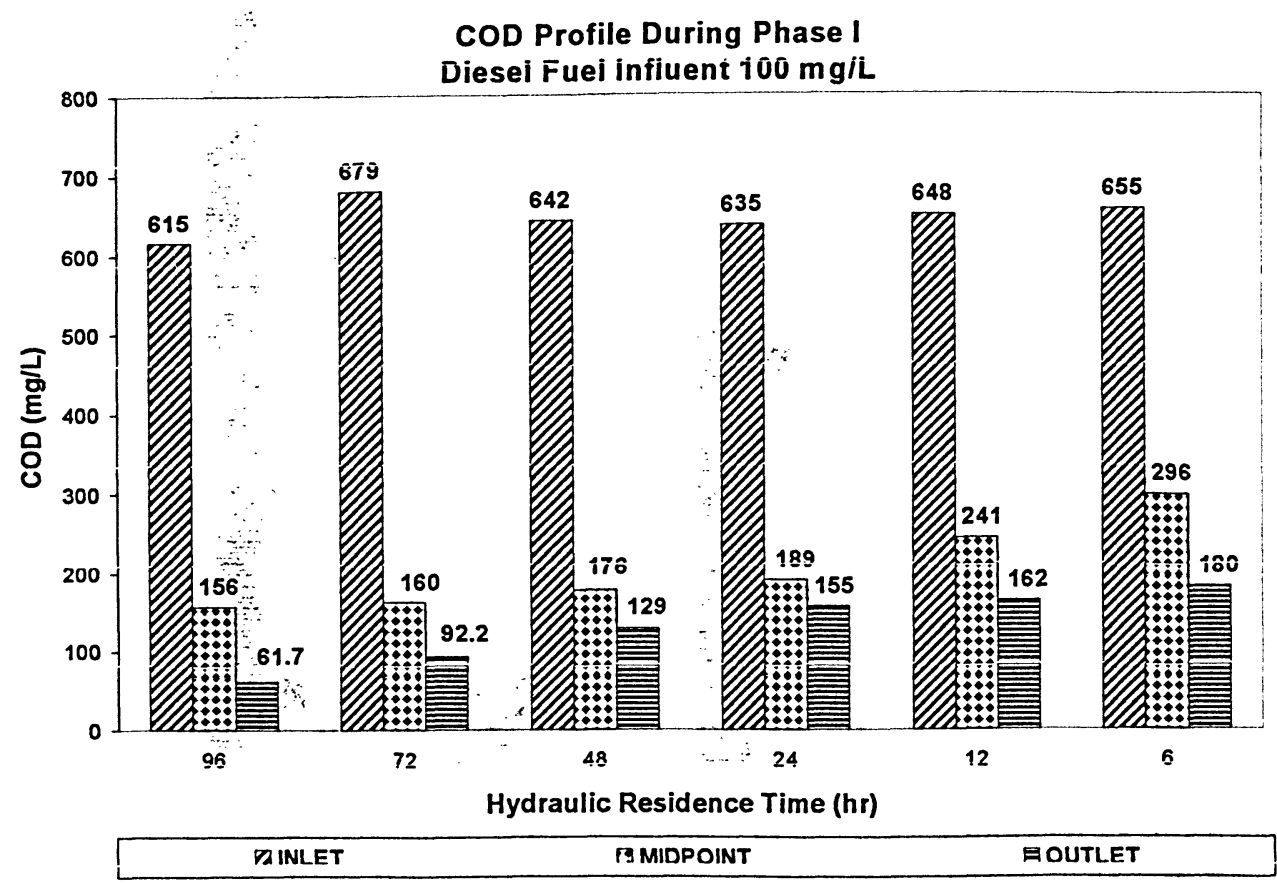

PHASE I

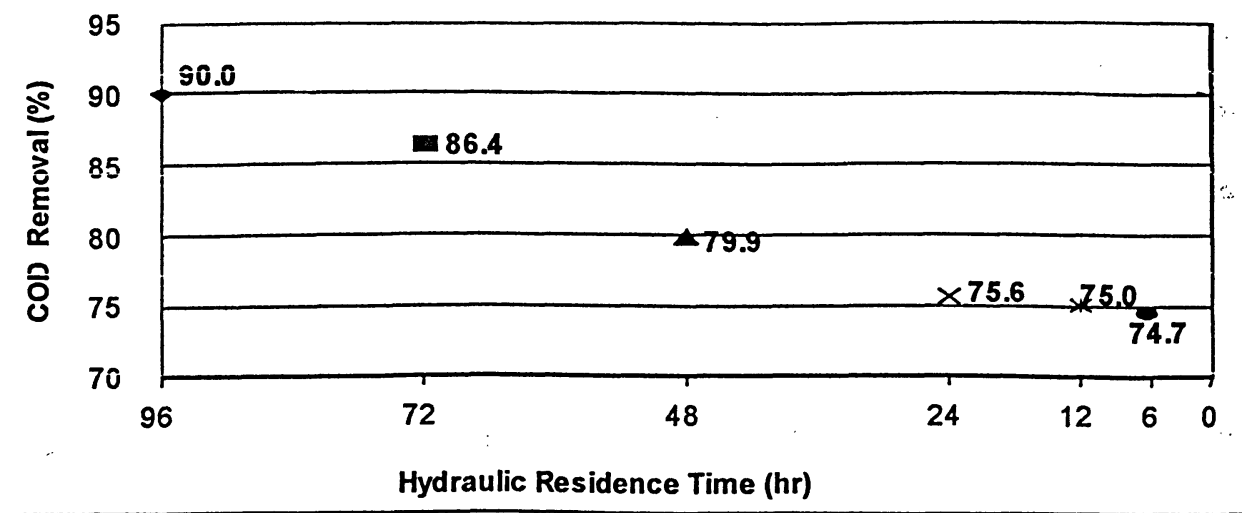

HRT $96 \mathrm{hr}$ HRT 72hr HRT $48 \mathrm{hr} \times$ HRT $24 \mathrm{hr}$ 
In order to determine the average value and to reduce experimental errors two samples were taken from each sampling point. The values of COD concentrations $(\mathrm{mg} / \mathrm{L})$ for each experimental run can be found in Appendix B, Tables B 1 - B 4 for experimental runs for Phase I-IV. As Figure 22 indicates COD removal efficiency was greater than $74.7 \%$ during Phase I for HRT as low as 6 hours, hence an increase in HRT was accompanied with an increase in COD removal capability.

FIGURE 22. COD CONCENTRATIONS AND THE COD REMOVAL PERCENTAGE AT VARIOUS POINTS IN THE AFBR, PHASE II

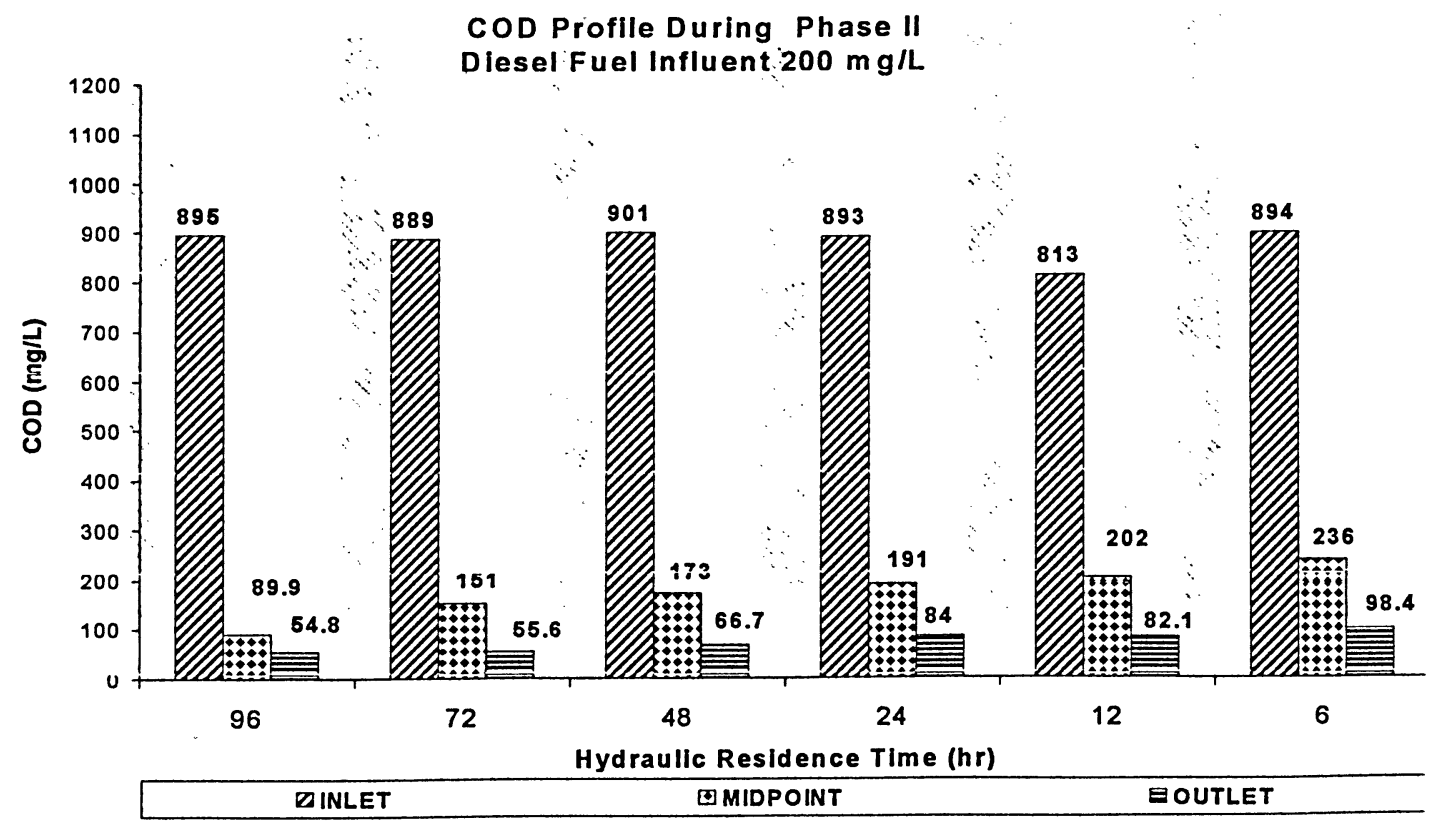

PHASE II

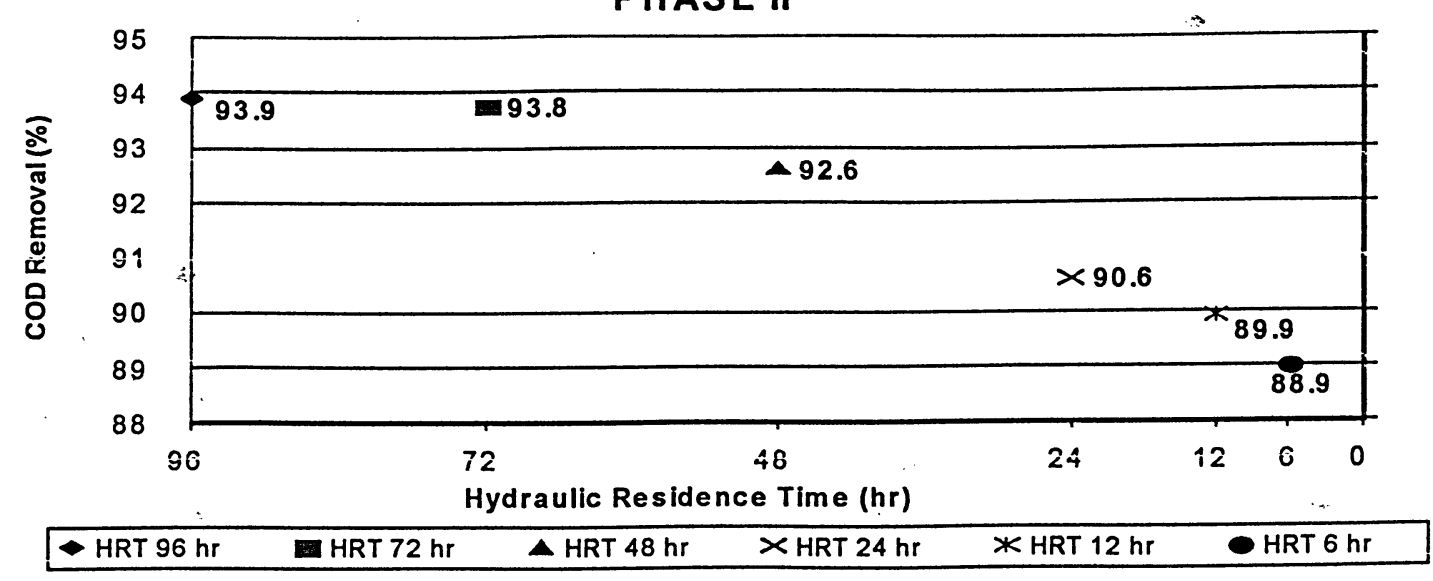


Figure 23 shows a COD removal capability of $86.7 \%$ during phase III at flowrate of $1200 \mathrm{~L} / \mathrm{d}$ for a HRT as low as 6 hours. The increase in HRT for the same influent concentration was associated the increase of COD removal percentage because of higher utilization of diesel fuel by the anaerobic microorganisms at a higher contact time with them

FIGURE 23. COD CONCENTRATIONS AND THE COD REMOVAL PERCENTAGE AT VARIOUS POINTS IN THE AFBR, PHASE III

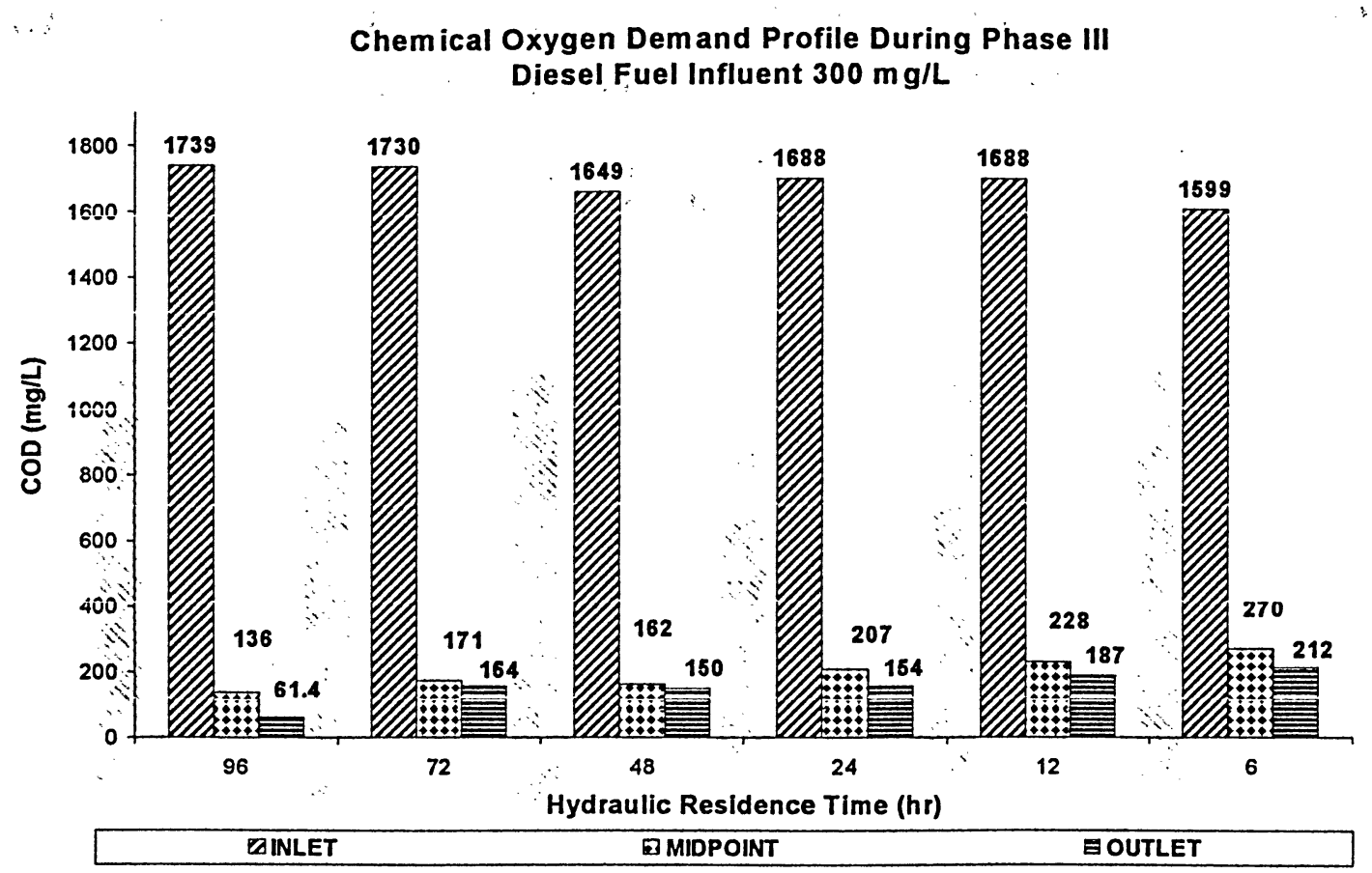

PHASE III

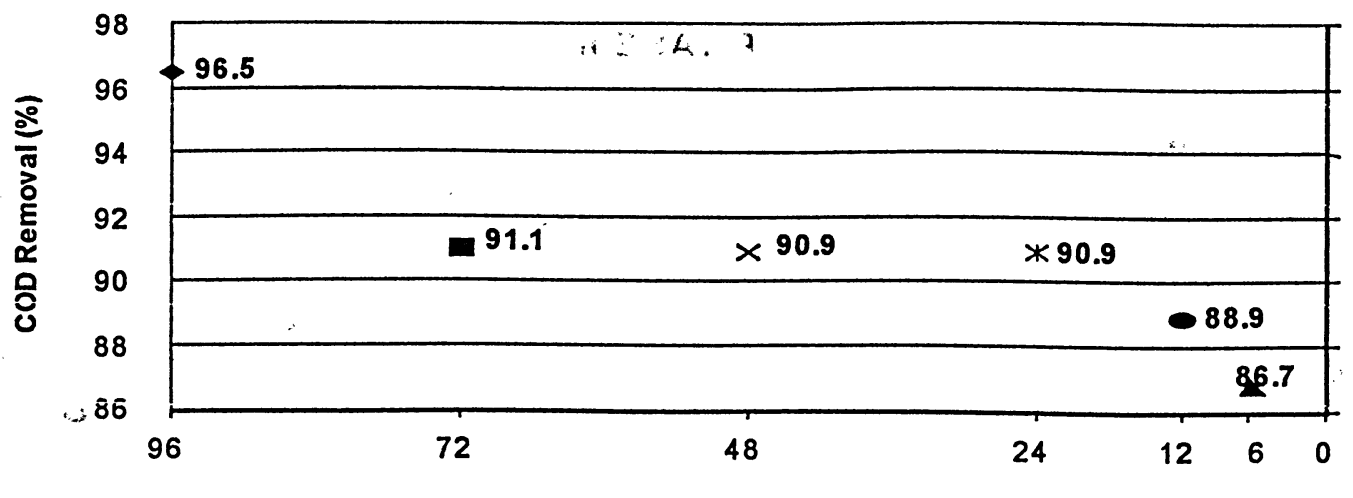

Hydraulic Residence Time (hr) 
The feedwater measured at the outlet sampling port contained less than $212 \mathrm{mg} / \mathrm{L} \mathrm{COD}$ concentration during this investigation (Figure 21-23).

Figure 24 shows the COD removal capability for Phase I, Phase II and Phase III. The increase in HRT and/or the influent concentration were accompanied by an increase of COD removal efficiency. Figure 24 shows that the optimum COD removal efficiency is reached in Phâse II. These results are in accordance with the results from gas chromatogram evaluations (Section 4.1).

FIGURE 24. COD REMOVAL CAPABILITY FO RH PHASE İ, PHASE II AND PHASE III.

\section{COD Removal Capabllity For Phase I, Phase II And Phase III}

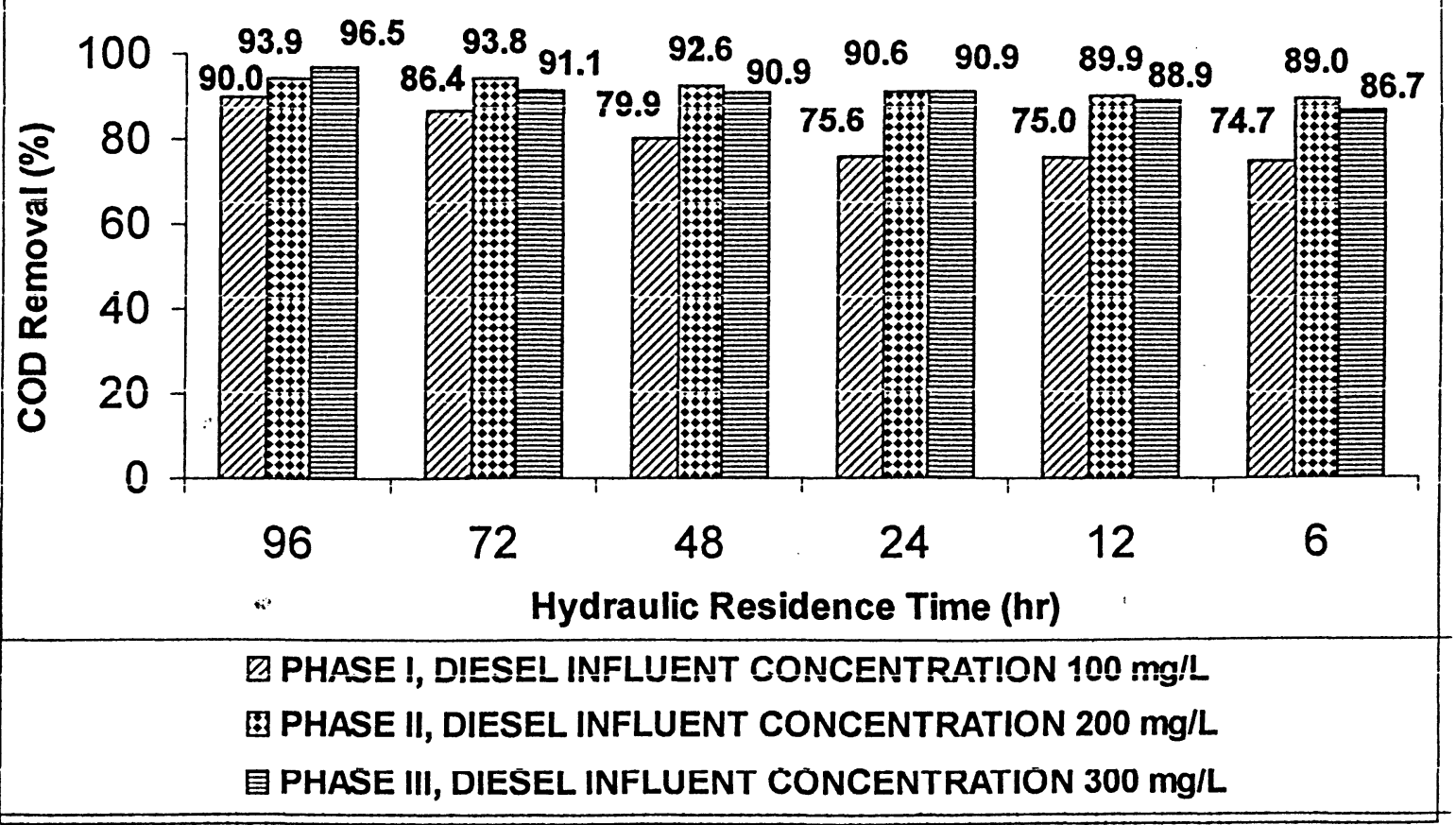


FIGURE 25. COD CONCENTRATIONS AND THE COD REMOVAL PERCENTAGE AT VARIOUS POINTS IN THE AFBR, PHASE IV

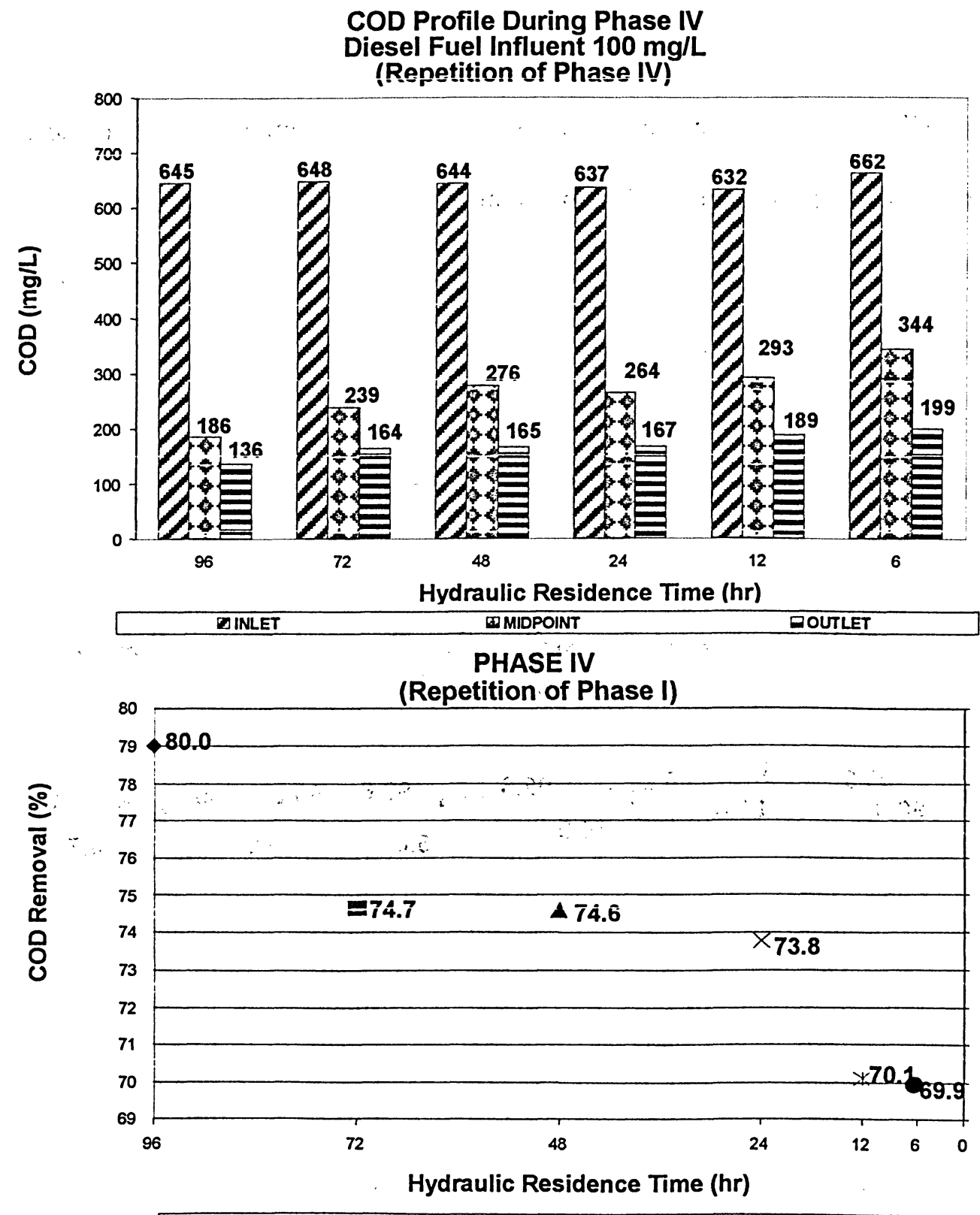

$\bullet$ HRT $96 \mathrm{hr}$ EHRT $72 \mathrm{hr} \triangle \mathrm{HRT} 48 \mathrm{hr} \quad \times$ HRT $24 \mathrm{hr} \quad *$ HRT $12 \mathrm{hr}$ OHRT $6 \mathrm{hr}$

Figure 25 shows that COD removal percentage was greater than $69.9 \%$ during Phase IV (Phase IV is a repetition of Phase I after 2 months) for a HRT as low as 6 hours. From comparing the diesel fuel removal efficiency of Phase I and Phase IV, it was noticed less 
than $5 \%$ deviation (Figure 19). The same cannot be said for the COD removal capability of Phase I and Phase IV (Figure 26). The explanation for these results is related to the fact that certain aromatic hydrocarbons are resistant to the oxidizing conditions of the COD test (Metcalf and Eddy, 2002). It can be suggested that the existence of more aromatic hydrocarbons in the feedwater of Phase I is the major factor causing higher variation in COD removal capability of Phase I and Phase IV (Figure 19 and Figure 26).

\section{FIGURE 26. COD REMOVAL CAPABILITY FOR PHASE I AND PHASE IV}

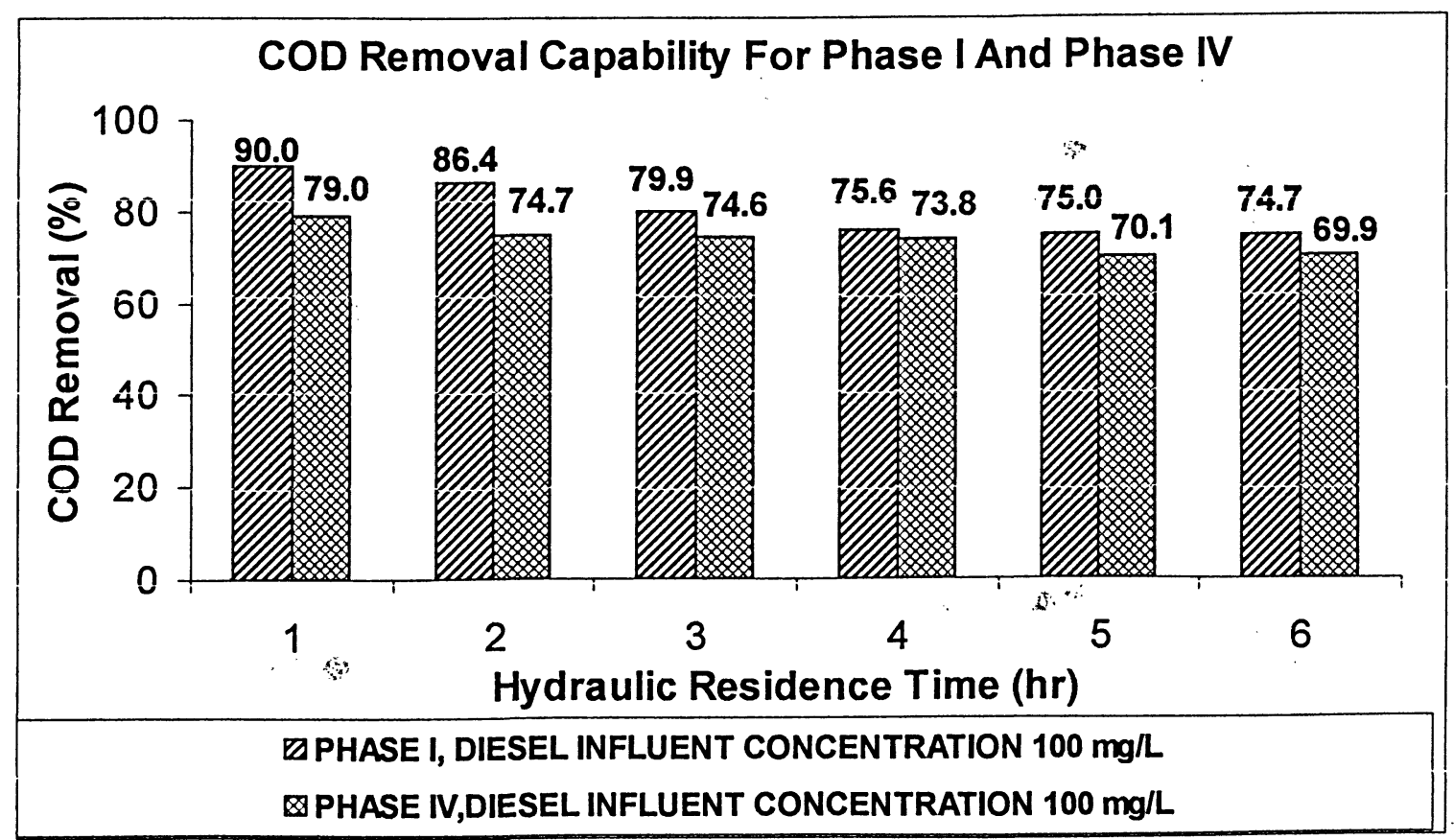

Figure 27 shows that COD removal efficiency depended on COD loading rate and HRT. Low COD loading rate and high HRT resulted in high COD removal efficiency. The COD removal efficiency decreases while increasing the COD loading rate (Figure 27). However, the COD removal efficiency seems to level off, when the COD loading rates 
exceeds $0.5 \mathrm{Kg} / \mathrm{m}^{3}$ day. More than $69.9 \%$ of influent $\mathrm{COD}$ was removed, which indicates that the Anaerobic Fluidized Bed system was highly effective.

FIGURE 27. VARIATION OF THE COD LOADING RATE AS A FUNCTION OF THE COD REMOVAL EFFICIENCY

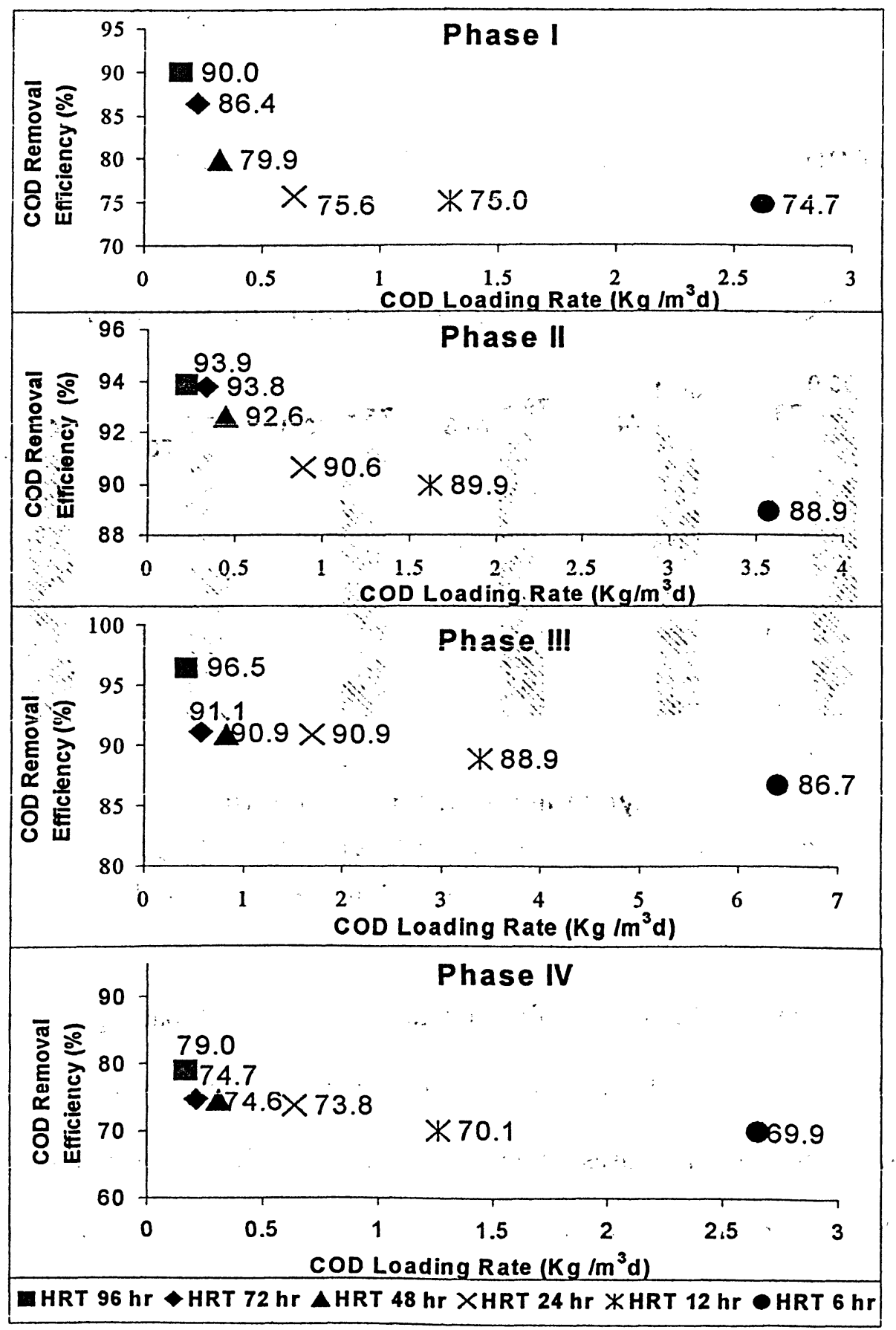




\subsection{Adsorption of Diesel Fuel on Granular Activated Carbon (GAC)}

\subsubsection{Introduction}

The specific capacity of a GAC to adsorb organic compounds is related to: molecular surface attraction, total surface area available per unit weight of carbon, and concentration of contaminants in the wastewater (CARBTROL Corporation, 2004). There is great variation in the adsorbability of dissolved/suspended substances, and also great variability in the adsorptive capacity of different activated carbons. The standard procedure for evaluating diesel fuel adsorption in GAC is by means of the adsorption isotherm. The adsorption isotherm represents an empirical relationship between the amount of contaminant adsorbed per unit weight of activated carbon and its equilibrium water concentration. Freundlich model is one of the most widely used isotherms for the description of adsorption equilibrium (Freundlich, 1906):

$$
x / m=K C_{e}^{1 / n}
$$

where:

$\mathrm{x} / \mathrm{m}=$ Amount of diesel fuel adsorbed per unit weight of GAC

$\mathrm{C}_{\mathrm{e}}=$ Concentration of diesel remaining in solution after adsorption is complete (at equilibrium) $(\mathrm{mg} / \mathrm{L})$

$\mathrm{K}=$ Empirical constant that is taken as an indicator of adsorption capacity

$1 / \mathrm{n}=$ Empirical constant related to the magnitude of the adsorption driving force

The constants $\mathrm{K}$ and $1 / \mathrm{n}$ can be determined by plotting the logarithmic form of Freundlich equation: $\quad \log (x / m)=\log K+(1 / n) \log C_{e}$

The slope of the line developed is equal to $1 / \mathrm{n}$ and the intercept equal to K. A Freundlich adsorption isotherm was determined by preparing several identical bottles of activated 
carbon suspended in water. Varying amounts of a diesel fuel were added to the bottles, and all were mixed until adsorption had reached equilibrium under conditions of constant temperature and pressure. Then the carbon was filtered out and the solutions were analyzed to find how much diesel fuel remained unadsorbed in each bottle. The $x / m$ is calculated using the Equation 32 and the two Freundlich constants. The capacity in $\mathrm{mg} / \mathrm{g}$ of carbon on the $\mathrm{Y}$-axis that corresponds to the value of $1.0 \mathrm{mg} / \mathrm{L}$ on the $\mathrm{X}$-axis is the one value used by international agreement (Fox, 1989). If the isotherm does not cross the 1.0$\mathrm{mg} / \mathrm{L}$ point, the line is artificially extrapolated to that level for the purpose.

\subsubsection{Experimental Procedure}

To determine the removal of diesel fuel due to adsorption, GAC adsorption isotherm experiments were conducted using the bottle point method (Miller et al. 1998). The experiments were performed under anaerobic conditions at $30^{\circ} \mathrm{C}$ and in absence of microorganisms. Anaerobic conditions were obtained by puging nitrogen in the headspace of bottles. (Fox, 1989). During this experiment 8 clean dry 250 conical flasks fitted with stoppers were used. First $10 \mathrm{~g}$ (weighted accurately $\pm 0.001 \mathrm{~g}$ ) of granular activated carbon were added to each flask. Then, eight different concentrations of diesel fuel solutions $(300 \mathrm{mg} / \mathrm{L}, 200 \mathrm{mg} / \mathrm{L}, 100 \mathrm{mg} / \mathrm{L}, 10 \mathrm{mg} / \mathrm{L}, 8 \mathrm{mg} / \mathrm{L}, 6 \mathrm{mg} / \mathrm{L}, 4 \mathrm{mg} / \mathrm{L}$ and 2 $\mathrm{mg} / \mathrm{L}$ ) were prepared in $500 \mathrm{ml}$ flasks. To each $250 \mathrm{ml}$ flask, $100 \mathrm{ml}$ aliquot of one of the eight-diesel fuel solutions was added. The flasks were tumbled for 24 hours to assist the equilibration process. Finally, the eight solutions were filtered collecting the filtrate in clean, dry flasks. The filtrate was extracted with dichloromethane $(1: 1)$ and then the dichloromethane layer was passed through a glass wool filter filled with anhydrous granular $\mathrm{Na}_{2} \mathrm{SO}_{4}$. Duplicate samples of each were run in the GC-MS. From the GC-MS 
data we determined the concentration of the diesel fuel solutions at equilibrium. Results from the anaerobic isotherm tests are presented in Table 14.

TABLE 14. EXPERIMENTAL DATA FOR THE ANAEROBIC ADSORPTION ISOTHERM TEST

\begin{tabular}{|c|c|c|c|c|c|}
\hline Run & $\begin{array}{c}\text { Diesel } \\
\text { Fuel Solution } \\
\text { Before } \\
\text { Equilibration, } \\
(\mathrm{mg} / \mathrm{L})\end{array}$ & $\begin{array}{c}\text { Diesel Fuel } \\
\text { Solution } \\
\text { After } \\
\text { Equilibration, } \\
\text { (mg/L) } \\
\text { Trial } 1\end{array}$ & $\begin{array}{c}\text { Diesel Fuel } \\
\text { Solution } \\
\text { After } \\
\text { Equilibration, } \\
\text { (mg/L) } \\
\text { Trial } 2\end{array}$ & $\begin{array}{l}\text { Mean } \\
\text { Value } \\
\text { (Trial } 1 \\
\text { and } \\
\text { Trial 2), } \\
\text { (mg/L) }\end{array}$ & $\begin{array}{c}\text { Standard } \\
\text { Deviation } \\
\text { (Trial 1 } \\
\text { and } \\
\text { Trial 2), } \\
\text { (mg/L) }\end{array}$ \\
\hline 1 & 300 & 299.4 & 299.8 & 299.6 & 0.2828 \\
\hline 2 & 200 & 199.5 & 199.7 & 199.6 & 0.1414 \\
\hline 3 & 100 & 99.7 & 99.6 & $\overline{99.65}$ & 0.0707 \\
\hline 4 & 10 & 9.8 & 9.7 & 9.75 & 0.0707 \\
\hline 5 & 8 & 7.7 & 7.8 & 7.75 & 0.0707 \\
\hline 6 & $\overline{6}$ & 5.8 & 5.7 & 5.75 & 0.0707 \\
\hline 7 & 4 & 3.7 & 3.9 & 3.8 & 0.1414 \\
\hline 8 & 2 & 1.8 & 1.9 & 1.85 & 0.0707 \\
\hline
\end{tabular}


TABLE 15. CALCULATED VALUES FOR THE ANAEROBIC ADSORPTION

ISOTHERM TEST

\begin{tabular}{|c|c|c|c|}
\hline $\begin{array}{c}\text { Experimental } \\
\text { Run }\end{array}$ & Log Ce & $\begin{array}{c}\mathrm{x} / \mathrm{m}, \mathrm{mg} / \mathrm{g} \\
=\frac{(\mathrm{Co}-\mathrm{Ce}) \mathrm{mg} / \mathrm{L} * 0.1 \mathrm{~L})}{10 \mathrm{~g}}\end{array}$ & $\log (x / m)$ \\
\hline 1 & 2.4765 & 0.0040 & -2.3979 \\
\hline 2 & 2.3002 & 0.0040 & -2.3979 \\
\hline 3 & 1.9985 & 0.0035 & -2.4559 \\
\hline 4 & 0.9890 & 0.0025 & -2.6021 \\
\hline 5 & 0.8893 & 0.0025 & -2.6021 \\
\hline 6 & 0.7597 & 0.0025 & -2.6021 \\
\hline 7 & 0.5798 & 0.0020 & $\begin{array}{c}-2.6990 \\
\end{array}$ \\
\hline 8 & 0.2672 & 0.0015 & -2.8239 \\
\hline
\end{tabular}

The Freundlich adsorption isotherm was plotted from the experimental data shown on the Table 15 . The adsorption isotherm coefficients were determined by plotting $\mathrm{x} / \mathrm{m}$ versus $C_{e}$ on $\log -\log$ paper, the intercept when $C_{e}=1.0$ was the value of $(x / m)$ and the slope of the line was equal to $1 / \mathrm{n}$. (Figure 28 ). Thus, $\mathrm{K}=0.002$ and slope $1 / \mathrm{n}=0.1695$. 
FIGURE 28. LOG $(\mathrm{x} / \mathrm{m})$ Vs. $\log \mathrm{C}_{\mathrm{e}}$ FOR DETERMINATION OF K AND $\mathrm{n}$ CONSTANTS

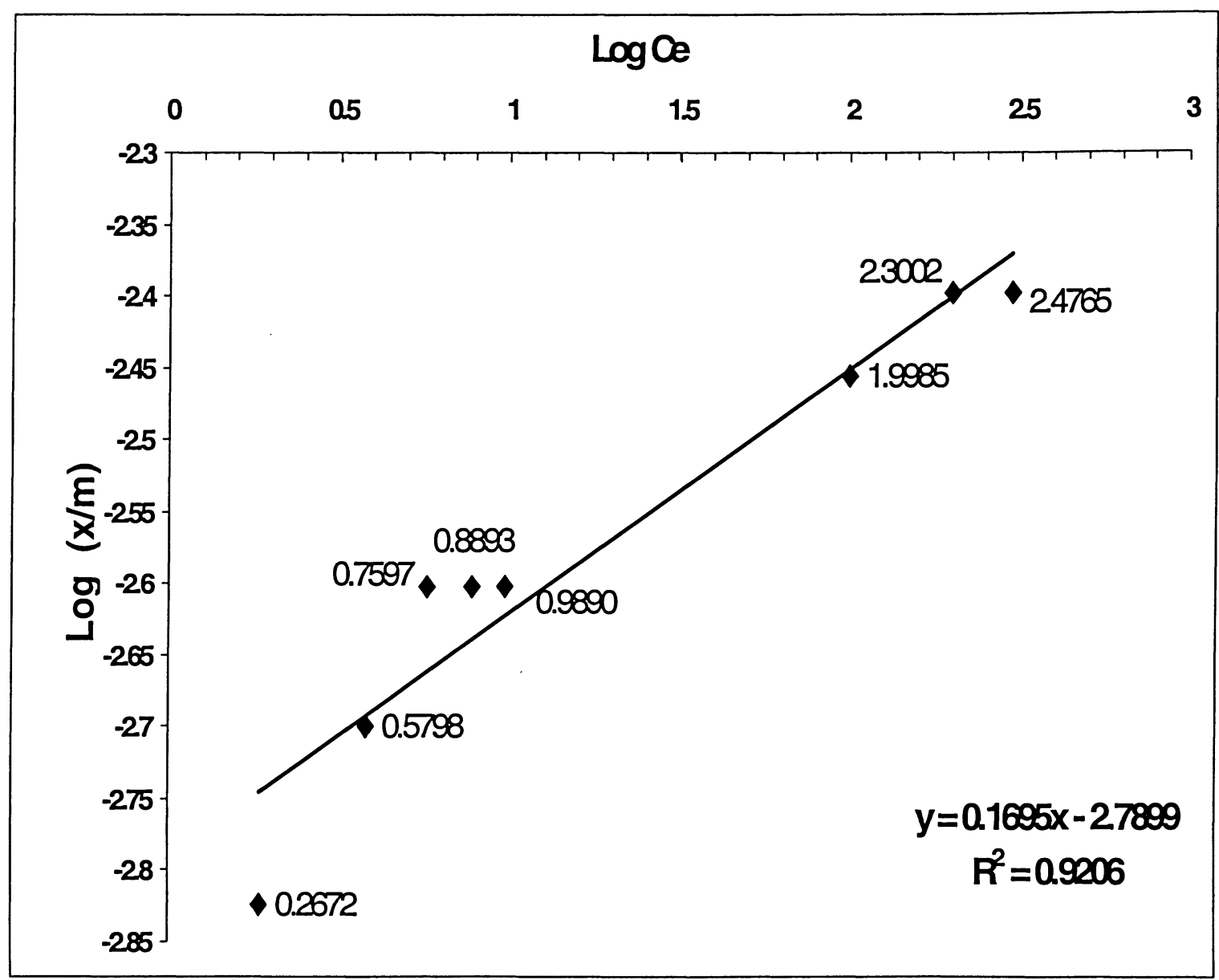

The isotherm data were linear (as shown in Figure 28) and fit a Freundlich- type isotherm model (Figure 29).

Anaerobic Isotherm $\frac{x}{m}=0.002 C_{e}^{0.1695}$ 


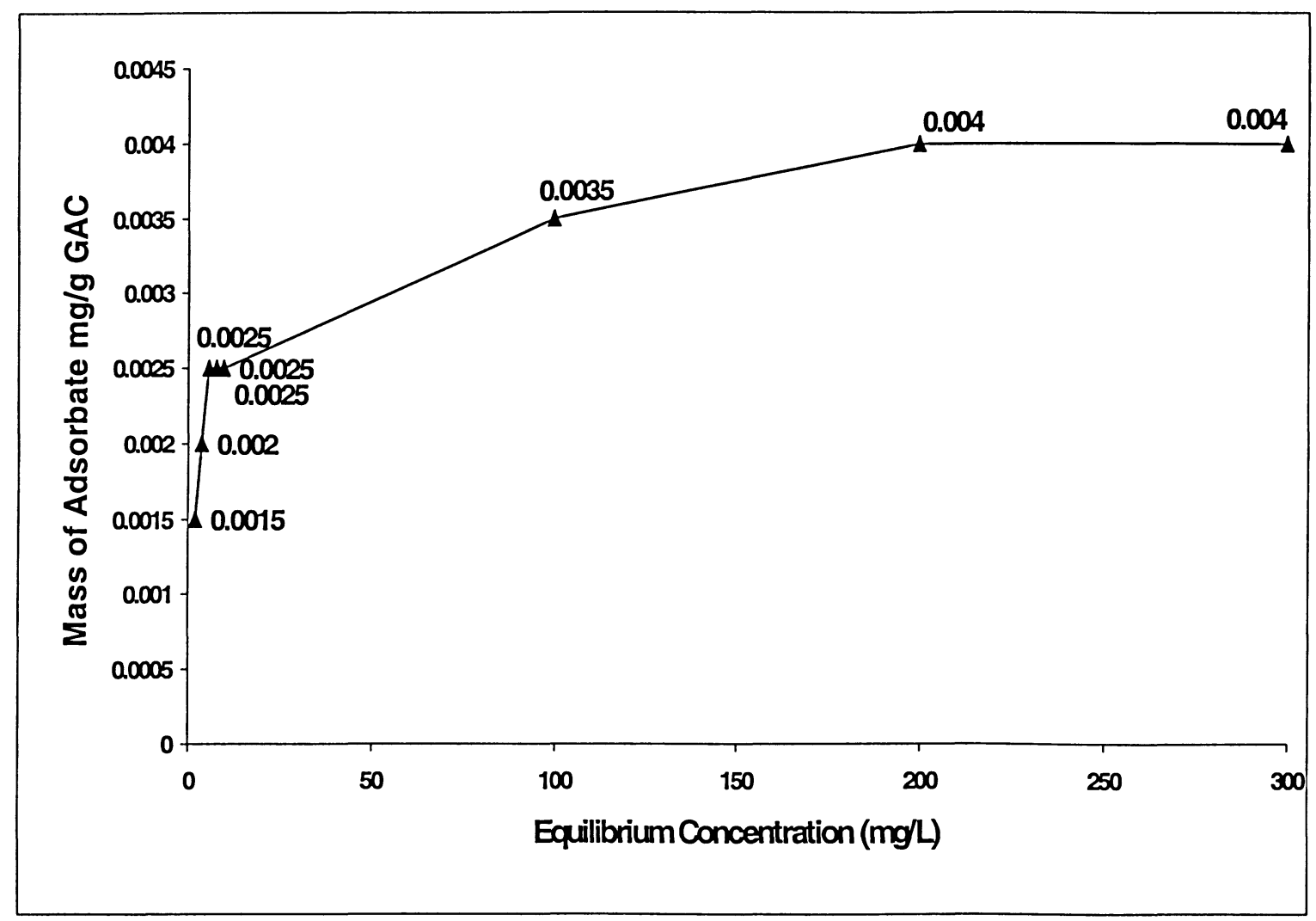

The adsorption capacity of GAC for diesel fuel at $30^{\circ} \mathrm{C}$ temperature is less than $0.004 \mathrm{mg}$ diesel fuel/g GAC (Figure 29). Based on the adsorption capacity and the total amount of GAC present in the AFBR (12500 g) the removal of diesel fuel due to GAC adsorption can be considered negligible $(\sim 0.3 \%)$ compared to the total diesel removal (i.e. 60.92 $\mathrm{mg} / \mathrm{L}$ for Phase I at HRT of 6 hours, Figure 14)

The chromatograms of Anaerobic Adsorption Isotherm Test are located in Appendix E, Figures $\mathrm{E} 1$ to $\mathrm{E} 16$. 


\subsection{Biofilm Thickness}

Biofilm was attached on the GAC particles after the first 65 days of the reactor operation in batch mode. The period between the first contact of the microorganism with diesel fuel hydrocarbons and the time point when a reduction in diesel fuel concentration can be observed is called acclimation phase. This acclimation period is not long considering that anaerobic microorganisms need usually 3-6 months. For industrial application it is imperative to reduce the acclimation period. It can be suggested that microbial inoculation (with biomass taken from a Rotating Biological Contactor treating diesel contaminated water) reduced the acclimation period. The AFBR was operated in batch with fresh diesel fuel influent every two days. The effect of diesel fuel feeding pattern in the acclimation period was not investigated. A uniform biofilm layer followed biofilm formation on the crevices of the GAC rough surface, as seen in Figure 25. The biofilm thickness $(\mu \mathrm{m})$ was measured from white light obtained by using an $\times 20$ objective. At the top of the AFBR it was noticed that smaller particle's diameter was associated with thicker biofilm layer $(120 \mu \mathrm{m})$. At the bottom of the reactor particles had a smaller biofilm thickness growing on a higher diameter support. From the calculations in Appendix $\mathrm{A}$ it can be noted that the particle density for a $841 \mu \mathrm{m}$ diameter GAC decreased from $1500 \mathrm{~kg} / \mathrm{m}^{3}$ to $1288 \mathrm{~kg} / \mathrm{m}^{3}$ (with biofilm thickness of $120 \mu \mathrm{m}$ ). Calculations in Appendix A showed that the terminal velocity decreased from $3.8 \mathrm{~cm} / \mathrm{s}$ for clean particles to $3.4 \mathrm{~cm} / \mathrm{s}$ for biocovered particles when the biofilm thickness was $120 \mu \mathrm{m}$. The biofilm covered particles moved up higher in the AFBR bed as a result of the decrease in the bioparticle density. The biofilm growth during the reactor operation increased the particles diameter, but decreased the particles density. 
FIGURE 30. WHITE LIGHT (MICROSCOPE) IMAGE OF STAGES IN BIOFILM FORMATION ON THE SURFACE OF A GAC PARTICLE A) CLEAN PARTICLE; B) BIOFILM ATTACHMENT INITIALLY IN THE CREVICES OF GAC PARTICLE C) FULLY DEVELOPED BIOFILM
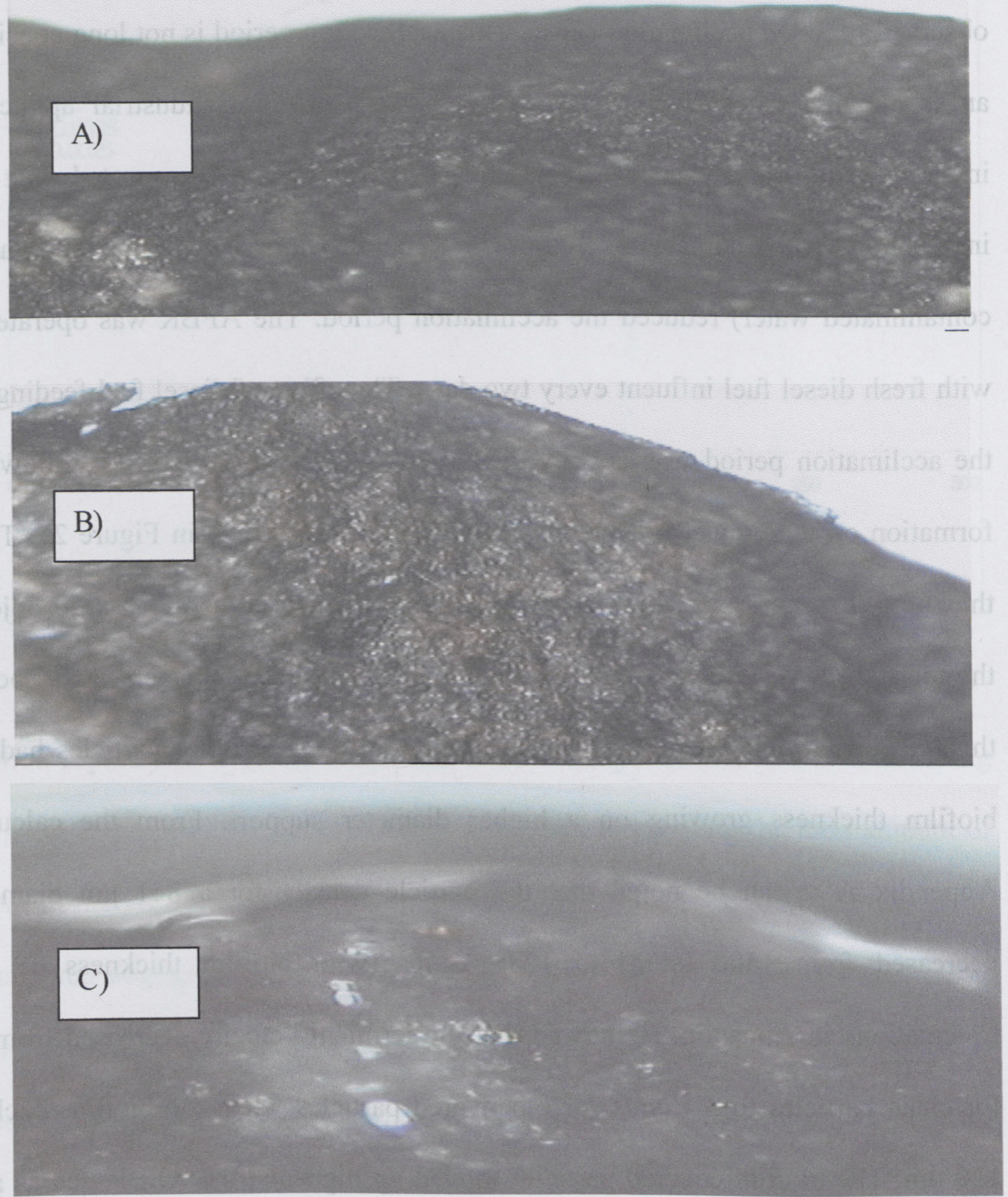


\section{CHAPTER 5. CONCLUSIONS AND RECOMMENDATIONS}

\subsection{Conclusions}

The following conclusion can be drawn from this investigation:

- Diesel fuel contaminated water was successfully treated anaerobically in a GACAFB bioreactor. The contributions of both biological degradation and adsorption on the GAC were investigated. It was concluded that biological degradation is by far the principal process in the degradation of diesel fuel. Indeed, GAC particles were mostly inert.

- Diesel removal efficiency was $58.6 \%$ for influent concentration of $100 \mathrm{mg} / \mathrm{L}$, $80.9 \%$ for influent concentration of $200 \mathrm{mg} / \mathrm{L}$ and $84.1 \%$ for influent concentration of $300 \mathrm{mg} / \mathrm{L}$ at HRT of 6 hours and flowrate $1200 \mathrm{~L} / \mathrm{d}$. An optimum concentration between $200 \mathrm{mg} / \mathrm{L}$ and $300 \mathrm{mg} / \mathrm{L}$ was observed for the fluidized bed bioreactor used.

- The increase of the HRT and/or influent diesel concentration was accompanied by an increase in the removal efficiency.

- COD reduction greater than $69.9 \%$ was achieved during the continuous operation of the AFBR at a flowrate of $1200 \mathrm{~L} / \mathrm{d}$ and COD influent concentration of 1599 $\mathrm{mg} / \mathrm{L}$.

- Diesel fuel concentration in the treated wastewater was less than $50 \mathrm{mg} / \mathrm{L}$ at HRT of 6 hours and flowrate $1200 \mathrm{~L} / \mathrm{d}$ that satisfies the requirement for (level II) Moderate Sensitivity Sites. 


\subsection{RECOMMENDATIONS}

Based on the experience of this research project, and the results obtained, the following studies are suggested:

- The treatment of the diesel fuel contaminated groundwater using various media types (sand, fired clay, porous glass beads, plastic beads with densities slightly greater than water, sepiolite, pumice, kaolinite) for biofilm formation.

- The optimum conditions to reduce the acclimation period of the biomass in the Fluidized Bed Reactor (the effect of diesel fuel feeding pattern and microbial inoculation in the acclimation period) need to be researched.

- The study of other complex mixtures of persistent organic compounds in the AFB reactor. Real wastewaters are complex mixtures in which many components are unknown. 


\section{REFERENCES:}

1. Alexander, M; (1999), "Biodegradation and Bioremediation", $2^{\text {nd }}$ edition, Academic Press, San Diego, USA.

2. Alvarez-Cuenca, M; (1979), "Mass transfer in two and three-phase fluidized beds", Ph. D. Thesis, University of Western Ontario, London, Canada.

3. Alvarez-Cuenca, M; and Anthony, E.J; (1995), "Pressurized fluidized bed combustion", London, Blackie Academic \& Professional, edited by M. Alvarez Cuenca and E.J. Anthony- 1.ed.

4. APHA, AWWA and WPCF (1995), "Standard Methods for the examination of water and wastewater", $19^{\text {th }}$ edition. Edited by Eaton, A. D; Clesceri, L. S; Greenberg, A.E., Washington D.C.

5. Atlas, R. M; (1981), Microbiol. Rev. Volume 45, Issue 1, pp 180.

6. ATSDR (1990). "Toxicological profile for polycyclic aromatic hydrocarbons". U.S. Department of Health and Human Services, Public Health Service. TP-9020.

7. Ball, H. A; Johnson, H.A; Reinhard, M; and Spormann, A; (1996), "Initial reactions in anaerobic ethylbenzene oxidation by a denitrifying bacterium strain EB1", J. Bacteriol. Volume 178, No. 19, pp 5755-5761.

8. Baryshnikova, L. M; Grishchenkov, V. G; Arinbasarov, M. U; Shkidchenko, A. N; and Boronin, L. M; (2001), "Biodegradation of Oil Products by Individual Degrading Strains and Their Associations in Liquid Media". Applied Biochemistry and Microbiology, Volume 37, Issue 5, pp 463-468. 
9. Bigmami, L; Eramu, B; Gavasci, R; Ramadori, R; and Rolle, E; (1991), "Modelling and experiments on fluidized bed biofilm reactors". Wat. Sci. Tech. Volume 24, Issue 7, pp 47-58.

10. Blumer, M; (1976). "Polycyclic aromatic compounds in nature". Sci. Amer., pp $35-45$.

11. Bolanos, E. Q; (2000), "Oxygen transfer and nitrification processes in a three phase fluidized bed reactor", Masters Thesis-University of Guelph.

12. Boopathy, R; (2003), "Anaerobic degradation of No. 2 diesel fuel in the wetland sediments of Barataria-Terrebonne estuary under various electron acceptor conditions", Bioresource technology, Volume 86, pp 171-175.

13. Bouwer, E.J; (1992). "Bioremediation of organic contaminants in the subsurface" In: Mitchell, R. Ed., Environmental Microbiology, Wiley, New York, pp 287318.

14. Brock, T; Madigan, M; Martinko, J; and Parker, J; (1997), "Biology of microorganisms", $8^{\text {th }}$ edition, Prentice hall, New Jersey.

15. Buffiere, P; Steyer, J.P; Fonade, C; and Moletta, R; (1998), "Modeling and experiments of the influence of biofilm size and mass transfer in a fluidized bed reactor for anaerobic digestion”. Wat. Res. Volume 32,No3.pp 657-668.

16. CARBTROL Corporation, (2004), Available from: http://www.carbtrol.com/water\&waste.pdf [Accessed 4 June 2004].

17. Chang, H.T; Rittman, B.E; Amar, D; Heim, R; Ehlinger, O; Lesty, Y; (1991), "Biofilm detachment mechanisms in a Liquid - Fluidized Bed", Biotechnology and Bioengineering, Volume 38, pp 499-506. 
18. Chen, J.J.J; (1987), "Comments on "Improved equation for calculation of minimum fluidization velocity", Ind.Eng.Chem.Res. Volume 26, pp 633-634.

19. Cookson, J. T; (1995), "Bioremediation Engineering: Design and Application", McGraw Hill Inc, New York.

20. Cooper, P. F; and Atkinson, B; (1981), "Biological fluidized bed treatment of water and wastewater", Horwood, England.

21. Diaz, S.M.C; (2003), "Oxygen transfer in a three phase fluidized bed reactor using the two zone model", Thesis-Ryerson Polytechnic University.

22. Duggal, K. N; Vyas, S. K; and Sandhar, N. S; (1987), "Biogas technology". Ludhiana: USG Publishers and Distributors.

23. Environment Canada, (1994), ETC Biennial Report, Environmental Technology Centre Report, Series No. DO 1-93/94 (website:http://www.etccte.ec.gc.ca/publications/biennial/birep1994_e.html\#6.2)

24. Environment Canada, (2004), Water Policy and Coordination Directorate, Available from: http://www.ec.gc.ca/water/en/info/pubs/primer/e_prim02.htm\#a1 [Accessed 4 June 2004].

25. Ergun, S; (1952), Chemical Engineering Prog. Volume 48, pp 89.

26. Erickson, M; (2000), "Biodegradation of hydrocarbons in soil and water", Ph.D. Thesis, Department of Biotechnology, Royal Institute of Technology, Stockholm, Sweden.

27. Flora, J. R. V; Suidan, M. T; Wellner, A. M; and Boyer, T. K; (1993), “Anaerobic treatment of a simulated high-strength industrial wastewater containing chlorophenols". Res. J WEF, Volume 26, Issue 1, pp 21-31. 
28. Fox, P; (1989). "An innovative reactor design for the treatment of biologically inhibitory wastewater". Ph.D. Dissertation, Department of Civil Engineering, University of Illinois, Urbana-Champaign, $\mathrm{IL}$.

29. Fox, P; Suidan, M.T; and Bandy, J.T; (1990), "A comparison of media types in acetate fed expanded bed anaerobic reactors". Water Res, Volume 27, Issue 7, pp 827-35.

30. Freundlich, H; (1906), "Ueber die adsorption in Leosungen”, Z. Phys. Chem., Volume 57, pp 385-470.

31. García-Calderón, D; Buffiere, P; Moletta, R; and Elmaleh, S; (1998), "Influence of Biomass Accumulation on Bed Expansion Characteristics of a DFAFB Reactor", Biotechnology and Bioengineering, Volume 57,Issue 2, pp 136-144.

32. Garrett, T. K; (1991), "Automotive Fuels and Fuel Systems", Volume 2: Diesel. London: Pentech Press, pp 334.

33. Gavrilescu, M; (2002), "Engineering concerns and new developments in anaerobic wastewater treatment", Clean Technologies and Environmental Policy, Volume 3, Issue: 4, pp. $346-362$.

34. Gupta, C.K; (1999), "Fluid Bed Technology in Materials Processing", edited by C.K. Gupta, D; Sathiyamoorthy, Boca Raton, Fla. CRC Press, pp 6.

35. Health and Welfare Canada, (1989). "A report of the Federal-Provincial Advisory Committee on Environmental and Occupational Health. Rep. No. EHD-TR-156". Environmental Health Directorate, Ottawa.

36. Hsu, C. S; (2000). Diesel Fuel Analysis, in "Encyclopedia of Analytical Chemistry", John Wiley, pp 6613-6622. 
37. Huang, T; Wei, F; Xu, S; Gu, Y; and Qian, S;(1989). "Application of GC/MS in the analysis of diaromatics, polyaromatics and polar compounds of light diesel oil from catalytic cracking", Shiyou Huagong, Volume 18, pp 328-333.

38. Huesemann, M. H; (1995), Environ. Science and Technology, Volume 29, Issue $1, \mathrm{pp} 7$.

39. ILPI (Interactive Learning Paradigms Incorporated), (2004), Available from: http://www.ilpi.com/msds/ref/hydrocarbon.html [Accessed 4 June 2004].

40. Maier, R.M; Pepper, I. L; and Gerba, C. P; (2000), "Environmental Microbiology", Academic Press, Boston.

41. Maloney, S. W; Adrian, N. R; Hickey, R. F; and Heine, R. L; (2002), “Anaerobic treatment of pinkwater in fluidized bed reactor containing GAC", Journal of hazardous materials, Volume 92,Issue 1, pp 77-88.

42. Marin, P; Alkalay, D; Guerrero, L; Chamy, R; and Schiappacasse, M.C; (1999), "Design and startup of an Anaerobic Fluidized Bed Reactor", Wat. Sci. Tech. Volume 40,No.8, pp 63-70.

43. Marquez-Rocha, F. J; Hernandez-Rodriguez, V; and Teresa-Lamela, M. A; (2001), "Biodegradation of diesel oil in soil by a microbial consortium", Water, Air, and Soil Pollution, Volume 128, pp 313-320.

44. Metcalf \& Eddy, (2002), "Wastewater Engineering Treatment and Reuse”, 4th edition, revised by George Tchobanoglous, Franklin L. Burton, H. David Stensel. Tchobanoglous, George, McGraw-Hill, Dubuque, IA: pp 636, 1020-1030. 
45. Miller, K.M; Suidan, M.T; Sorial, G.A; Khododoust, A.P; Acheson, C.M; and Brenner, R.C; (1998), “Anaerobic treatment of soil wash fluids from a wood preserving site", Water Sci. Technol. Volume 38,Issue 7, pp 63-72.

46. Moteleb, M.A; Suidan, M.T; Kim, J; and Maloney, S. W; (2002), "Pertubated loading of a formaldehyde waste in an anaerobic granular activated carbon fluidized bed reactor", Water Research, Volume 36, Issue 15,pp 3775-3785.

47. NYSERDA, (1987), "Pilot anaerobic fluidized bed treatment of municipal sludge at Nassau County", New York State Energy Research and Development Authority Report, Ecotrol Inc, Westbury, New York, pp 24-26.

48. Olson, R. M; (1980). "Essentials of engineering-Fluid mechanics", Harper \& Row publishers, Fourth Edition, New York, USA.

49. Padron, H; 2004, Combined Anaerobic/Aerobic Treatment for Municipal Wastewater, Master of Science Thesis, University of New Orleans, pp 29-32.

50. Perryman, J.A; (2003), "Bioremediation of diesel contaminated water using a RBC", Bachelor of Science Thesis-Ryerson Polytechnic University, Toronto, Canada.

51. Alberta MUST, (1990), "Draft subsurface remediation guidelines for Underground Storage Tanks-Draft". Environment Canada-Ontario Region for Federal Facilities operating in Ontario website: http://www.on.ec.gc.ca/pollution/ecnpd/tabs/tab05-e.html.

52. Rehm, H.J; and Reiff, T; (1981), “Mechanism and occurrence of microbial oxidation of long chain alkanes". Adv. Biochem.Eng. Volume.19, pp 175-215. 
53. Rittman, B.E; and Mc Carty, P.L; (2001), "Environmental Biotechnology: Principles and Applications", Mc Graw Hill.

54. Sanders, W.T.M; Van Bergen, D; Bujis, S; Corstanje, R; Gerrits, M; Hoogerwerf, T; and Lettinga, G; (1996), "Treatment of waste activated sludge in an anaerobic hydrolysis upflow sludge bed reactor", EWPCA-Symposium, pp15.

55. Shieh, W.K; Sutton, P.M; and Kos, P; (1981), "Predicting Reactor Biomass Concentration in a Fluidized Bed System", J. Water Poll. Control Fed. Volume 53, pp 1574.

56. Skoog, D. A; West, D. M; and Holler, F. J; (1997), “Analytical Chemistry", $7^{\text {th }}$ edition. Saunders College Publishing, Toronto, Canada.

57. Song, Ch; Hsu, Ch. S; and Mochida, I; (2000), "Chemistry of diesel fuels", published by Taylor \& Francis, New York, pp 18.

58. Straub, K; and Buckholtz-Cleven, B; (1998), "Enumeration and Detection of anaerobic ferrous iron oxidizing, nitrate reducing bacteria from diverse European sediments", Volume 64,Issue 12, pp 4846-4856.

59. Suidan, M.T; Wuellner, A.M; and Boyer, T.K; (1991), “Anaerobic treatment of a high strength industrial waste bearing inhibitory concentration of $1,1,1-$ trichloroethane", Water Sci. Technol, Volume 23, pp 1385.

60. Trinet, F; Heim, R; Amar, D; Chang, H. T; and Rittmann, B. E; (1991), "Study of biofilm and fluidization of bioparticles in a three phase liquid-fluidized bed reactor", Water Sci. Tech. Volume 23, pp 1347-1354.

61. U.S. Environmental Protection Agency, (2004), Available from: http://www.epa.gov/epaoswer/hazwaste/test/pdfs/3510c.pdf [Accessed 4 June 2004]. 
62. Van Stempvoort, D.R; Lesage, S; Novakowski, K.S; Millar, K; Brown, S; and Lawrence, J.R; (2000), "Humic acid enhanced remediation of an emplaced diesel source in groundwater", Journal of Contaminant Hydrology, Volume 54,Issue 34, pp 249-276.

63. Vigneswaran, S; Balasuriyay, B.L.N; and Viraraghavan, T; (1986), "Anaerobic wastewater treatment-attached growth and sludge blanket process", Bangkok: ENSIC, website: http://www.cepis.opsoms.org/muwww/fulltext/repind54/anadow/anadow.html.

64. Wen, C.Y; and Yu, Y.H; (1966), "Mechanics of Fluidization”, Chem. Eng. Prog. Symp. Ser., Volume 62, pp 100.

65. Wiedemeier, T.H; Rifai, H. S; Newell, Ch. J; Wilson, J. T; (1999), “ Natural attenuation of fuels and chlorinated solvents in the subsurface", Published by John Wiley \& Sons Inc., Toronto, Canada, pp197-199.

66. Wilson, L.P; and Bower, E.J; (1997), "Biodegradation of aromatic compounds under mixed oxygen/denitrifying conditions: a review”, J. Ind. Microbiol. Biotechnol. Volume 18, Issue 2-3, pp 116-130.

67. Yoda, M; Shin, S.W; Watanabe, M; Kitigawa, M; and Miyaji, Y; (1987), "Anaerobic fluidized bed treatment with a steady state biofilm", Water Sci. Tech. Volume 19, pp 287.

68. Yoon, T. I.; Lee, H. S; Kim, C. G; (2004), “Comparison of pilot scale performances between membrane bioreactor and hybrid conventional wastewater treatment systems", Journal of Membrane Science, Volume: 242, Issue: 1-2, pp. $5-12$.

69. Yu, J; Ji, M; and Yue, P. L; (1999), "A three-phase fluidized bed reactor in the combined anaerobic/aerobic treatment of wastewater", Journal of Chemical Technology \& Biotechnology, Volume 74, Issue 7, pp 619 - 626.

70. Zink, G; and Lorber, K.E; (1995), "Mass spectral identification of metabolites formed by microbial degradation of Poly Aromatic Hydrocarbons (PAH)", Chemosphere, Volume 31, Issue 9, pp 4077-4085. 


\section{APPENDIX A-Sample Calculations}

\section{- Organic Loading Rate (OLR)}

The OLR is the average rate at which diesel fuel is introduced into a unit volume of the reactor and is normally reported as $\mathrm{kg}$ COD added per $\mathrm{m}^{3}$ reactor per day. The OLR accounts for both the influent flow rate and the influent substrate concentration according to Garcia-Calderon et al (1998):

OLR, $\mathrm{kg} \mathrm{COD} / \mathrm{m}^{3} / \mathrm{d}=\left\{\left[\mathrm{S}_{\mathrm{i}}\left(\mathrm{kg} \mathrm{COD} / \mathrm{m}^{3}\right) \times \mathrm{Q}_{\mathrm{i}}\left(\mathrm{m}^{3} / \mathrm{d}\right)\right] / \mathrm{V}\left(\mathrm{m}^{3}\right)\right\}$

Where: $\mathrm{V}=300 \mathrm{~L}=0.3 \mathrm{~m}^{3}$

For Phase I at HRT $96 \mathrm{hr}$

Where:

$$
\begin{aligned}
& \mathrm{S}_{\mathrm{i}}=615 \mathrm{mg} / \mathrm{l}=615 \mathrm{~g} / \mathrm{m}^{3} *(1 \mathrm{~kg} / 1000 \mathrm{~g})=0.615 \mathrm{~kg} \mathrm{COD} / \mathrm{m}^{3} \\
& \mathrm{Q}_{\mathrm{i}}=0.052 \mathrm{LPM}^{*}\left(\mathrm{~m}^{3} / 1000 \mathrm{~L}\right) *(60 \mathrm{Min} / \mathrm{Hr}) *(24 \mathrm{Hr} / \mathrm{d})=0.075 \mathrm{~m}^{3} / \mathrm{d}
\end{aligned}
$$

$\mathrm{OLR}=\left(\mathrm{Si} \times \mathrm{Q}_{\mathrm{i}}\right) / \mathrm{V}=0.046125 \mathrm{~kg} \mathrm{COD} / \mathrm{d} / 0.3 \mathrm{~m}^{3}=0.154\left(\mathrm{~kg} \mathrm{COD} / \mathrm{m}^{3} / \mathrm{d}\right)$

\section{For Phase II at HRT $96 \mathrm{hr}$}

$\mathrm{S}_{\mathrm{i}}=0.895 \mathrm{~kg} \mathrm{COD} / \mathrm{m}^{3}$

$\mathrm{Q}_{\mathrm{i}}=0.075 \mathrm{~m}^{3} / \mathrm{d}$

$\mathrm{OLR}=\left(\mathrm{Si} \times \mathrm{Q}_{\mathrm{i}}\right) / \mathrm{V}_{\mathrm{l}}=0.067125 \mathrm{~kg} \mathrm{COD} / \mathrm{d} / 0.3 \mathrm{~m}^{3}=0.224\left(\mathrm{~kg} \mathrm{COD} / \mathrm{m}^{3} / \mathrm{d}\right)$

\section{For Phase III at HRT $96 \mathrm{hr}$}

$\mathrm{Q}_{\mathrm{i}}=0.075 \mathrm{~m}^{3} / \mathrm{d}$

$\mathrm{S}_{\mathrm{i}}=1.739 \mathrm{~kg} \mathrm{COD} / \mathrm{m}^{3}$

$\mathrm{OLR}=\left(\mathrm{Si} \times \mathrm{Q}_{\mathrm{i}}\right) / \mathrm{V}_{\mathrm{l}}=0.130425 \mathrm{~kg} \mathrm{COD} / \mathrm{d} / 0.3 \mathrm{~m}^{3}=0.435\left(\mathrm{~kg} \mathrm{COD} / \mathrm{m}^{3} / \mathrm{d}\right)$ 


\section{- Calculation of \% COD Removal}

The treatment efficiency is the \% of substrate removed to the amount of substrate processed. It is usually reported a $\% \mathrm{COD}$ removed:

$$
\% C O D_{\text {removed }}=\frac{\left(C O D_{\text {inf luent }}-C O D_{\text {efluent }}\right) Q_{\text {in }}}{C O D_{\text {inf luent }} \cdot Q_{\text {in }}} \cdot 100=\frac{C O D_{\text {inf luent }}-C O D_{\text {effluent }}}{C O D_{\text {inf luent }}} \cdot 100
$$

For Phase I at HRT $96 \mathrm{hr}$

$$
\% C O D_{\text {removed }}=\frac{615(\mathrm{mg} / \mathrm{L})-61.7(\mathrm{mg} / \mathrm{L})}{615(\mathrm{mg} / \mathrm{L})} \cdot 100=89.96 \%
$$

\section{- Terminal Velocity}

The terminal velocity for the particle is given from the following formula:

$$
U_{t}=\left[\frac{4\left(\rho_{p}-\rho_{l}\right) g d_{p}}{3 \rho_{l} C_{D}}\right]^{\frac{1}{2}}
$$

The particle Reynolds number is:

$$
\operatorname{Re}_{p}=\frac{\rho_{l} U d_{p}}{\mu}=\frac{995.7\left(\frac{\mathrm{kg}}{\mathrm{m}^{3}}\right) \times 0.0062\left(\frac{\mathrm{m}}{\mathrm{s}}\right) \times 0.000841(\mathrm{~m})}{0.798 \times 10^{-3}\left(\frac{\mathrm{N} \cdot \mathrm{s}}{\mathrm{m}^{2}}\right)}=6.5
$$

The drag coefficient for Reynolds number in the range 0.4 to 500 is:

$$
C_{D}=\frac{10}{R e_{t}^{1 / 2}}=\frac{10}{6.5^{1 / 2}}=3.9
$$

The terminal velocity for the clean particle (without biofilm) for particle diameter, $d_{p}$, $841 \mu \mathrm{m}$ was: 


$$
U_{t}=\left[\frac{4(1500-995.7)\left(\frac{\mathrm{kg}}{\mathrm{m}^{3}}\right) \times 9.81\left(\frac{\mathrm{m}}{\mathrm{s}^{2}}\right) \times 0.000841(\mathrm{~m})}{3 \times 995.7\left(\frac{\mathrm{kg}}{\mathrm{m}^{3}}\right) \times 3.9}\right]^{1 / 2}=0.0378(\mathrm{~m} / \mathrm{s})=3.8(\mathrm{~cm} / \mathrm{s})
$$

The biocovered particle diameter, $\mathrm{d}_{\mathrm{p}}$, (for biofilm thickness, $120 \mu \mathrm{m}$ ) is:

$$
d_{b}=d p+2 \sigma=d p+2(120 \mu m)=841 \mu m+(2 \times 120 \mu m)=1081 \mu m
$$

The biocovered particle density is given as

$$
\rho_{b}=\rho_{s}\left(\frac{\mathrm{d}_{\mathrm{p}}^{3}}{d_{b}^{3}}\right)+\rho_{b f}\left(1-\frac{d_{p}^{3}}{d_{b}^{3}}\right)
$$

Biofilm density, $\rho_{\mathrm{bf}}$, was taken equal to $1100 \mathrm{Kg} / \mathrm{m}^{3}$ according to Buffiere et al. (1998).

$$
\rho_{b}=1500\left(\frac{\mathrm{kg}}{\mathrm{m}^{3}}\right)\left(\frac{0.000841^{3}\left(\mathrm{~m}^{3}\right)}{0.001081^{3}\left(\mathrm{~m}^{3}\right)}\right)+1100\left(\frac{\mathrm{kg}}{\mathrm{m}^{3}}\right)\left(1-\frac{0.000841^{3}\left(\mathrm{~m}^{3}\right)}{0.001081^{3}\left(\mathrm{~m}^{3}\right)}\right)=1288\left(\mathrm{~kg} / \mathrm{m}^{3}\right)
$$

Where the biocovered Reynolds number is:

$$
\operatorname{Re}_{b}=\frac{\rho_{l} U d_{b}}{\mu}=\frac{995.7\left(\frac{\mathrm{kg}}{\mathrm{m}^{3}}\right) \times 0.0062\left(\frac{\mathrm{m}}{\mathrm{s}}\right) \times 0.001081(\mathrm{~m})}{0.798 \times 10^{-3}\left(\frac{\mathrm{N} \cdot \mathrm{s}}{\mathrm{m}^{2}}\right)}=8.4
$$

Then the drag coefficient for Reynolds number in the range 0.4 to 500 is:

$$
C_{d}=\frac{10}{R e_{t}^{1 / 2}}=\frac{10}{8.4^{1 / 2}}=3.5
$$

The terminal velocity for the biocovered particle is:

$$
U_{t}=\left[\frac{4\left(\rho_{\mathrm{b}}-\rho_{l}\right) g d_{b}}{3 \rho_{l} C d}\right]^{\frac{1}{2}}=\left[\frac{4(1288-995.7)\left(\frac{\mathrm{kg}}{\mathrm{m}^{3}}\right) \cdot 9.81\left(\frac{\mathrm{m}}{\mathrm{s}^{2}}\right) \cdot 0.001081(\mathrm{~m})}{3 \cdot 995.7\left(\frac{\mathrm{kg}}{\mathrm{m}^{3}}\right) \cdot 3.5}\right]^{1 / 2}=0.0344(\mathrm{~m} / \mathrm{s})=3.4(\mathrm{~cm} / \mathrm{s})
$$




\section{APPENDIX B-Chemical Oxygen Demand}

Table B 1. Chemical Oxygen Demand Results-Phase I

\begin{tabular}{|c|c|c|c|c|c|}
\hline HRT & Sample Port & Run 1 & Run 2 & $\begin{array}{c}\text { Average Value } \\
\text { (Run1 and Run } \\
\text { 2) }\end{array}$ & $\begin{array}{c}\text { Standard } \\
\text { Deviation (Run } 1 \\
\text { and Run 2) }\end{array}$ \\
\hline \multirow{3}{*}{$96 \mathrm{hr}$} & Influent & 612 & 618 & 615 & 4.2426 \\
\hline & Midpoint & 154 & 158 & 156 & 2.8284 \\
\hline & Effluent & 60.4 & 63 & 61.7 & 1.8385 \\
\hline \multirow{3}{*}{$72 \mathrm{hr}$} & Influent & 671 & 687 & 679 & 11.3137 \\
\hline & Midpoint & 166 & 154 & 160 & 8.4853 \\
\hline & Effluent & 96.1 & 88.3 & 92.2 & 5.5154 \\
\hline \multirow{3}{*}{$48 \mathrm{hr}$} & Influent & 638 & 646 & 642 & 5.6569 \\
\hline & Midpoint & 173 & 179 & 176 & 4.2426 \\
\hline & Effluent & 128 & 130 & 129 & 1.4142 \\
\hline \multirow{3}{*}{$24 \mathrm{hr}$} & Influent & 641 & 629 & 635 & 8.4853 \\
\hline & Midpoint & 183 & 195 & 189 & 8.4853 \\
\hline & Effluent & 158 & 152 & 155 & 4.2426 \\
\hline \multirow{3}{*}{$12 \mathrm{hr}$} & Influent & 652 & 644 & 648 & 5.6569 \\
\hline & Midpoint & 245 & 237 & 241 & 5.6569 \\
\hline & Effluent & 167 & 157 & 162 & 7.0711 \\
\hline \multirow{3}{*}{$6 \mathrm{hr}$} & Influent & 653 & 657 & 655 & 2.8284 \\
\hline & Midpoint & 291 & 300 & 295.5 & 6.3640 \\
\hline & Effluent & 174 & 186 & 180 & 8.4853 \\
\hline
\end{tabular}


Table B 2. Chemical Oxygen Demand Results-Phase II

\begin{tabular}{|c|c|c|c|c|c|}
\hline HRT & Sample Port & Run 1 & Run 2 & $\begin{array}{l}\text { Average Value } \\
\text { (Run1 and Run } \\
\text { 2) }\end{array}$ & $\begin{array}{c}\text { Standard } \\
\text { Deviation } \\
\text { (Run } 1 \text { and Run } \\
\text { 2) }\end{array}$ \\
\hline \multirow{3}{*}{$96 \mathrm{hr}$} & Influent & 888 & 902 & 895 & 9.8995 \\
\hline & Midpoint & 84.7 & 95.1 & 89.9 & 7.3539 \\
\hline & Effluent & 50.2 & 59.4 & 54.8 & 6.5054 \\
\hline \multirow{3}{*}{$72 \mathrm{hr}$} & Influent & 894 & 884 & 889 & 7.0711 \\
\hline & Midpoint & 155 & 147 & 151 & 5.6569 \\
\hline & Effluent & 50.7 & 60.5 & 55.6 & 6.9297 \\
\hline \multirow{3}{*}{$48 \mathrm{hr}$} & Influent & 908 & 894 & 901 & 9.8995 \\
\hline & Midpoint & 179 & 167 & 173 & 8.4853 \\
\hline & Effluent & 63.3 & 70.1 & 66.7 & 4.8083 \\
\hline \multirow{3}{*}{$24 \mathrm{hr}$} & Influent & 887 & 899 & 893 & 8.4853 \\
\hline & Midpoint & 185 & 197 & 191 & 8.4853 \\
\hline & Effluent & 88.7 & 79.3 & 84 & 6.6468 \\
\hline \multirow{3}{*}{$12 \mathrm{hr}$} & Influent & 815 & 811 & 813 & 2.8284 \\
\hline & Midpoint & 208 & 196 & 202 & 8.4853 \\
\hline & Effluent & 86.3 & 77.9 & 82.1 & 5.9397 \\
\hline \multirow{3}{*}{$6 \mathrm{hr}$} & Influent & 899 & 889 & 894 & 7.0711 \\
\hline & Midpoint & 230 & 242 & 236 & 8.4853 \\
\hline & Effluent & 95.1 & 101.7 & 98.4 & 4.6669 \\
\hline
\end{tabular}


Table B 3. Chemical Oxygen Demand Results-Phase III

\begin{tabular}{|c|c|c|c|c|c|}
\hline HRT & Sample Port & Run 1 & Run 2 & $\begin{array}{c}\text { Average Value } \\
\text { (Run1 and Run } \\
\text { 2) }\end{array}$ & $\begin{array}{c}\text { Standard } \\
\text { Deviation (Run } 1 \\
\text { and Run 2) }\end{array}$ \\
\hline \multirow{3}{*}{$96 \mathrm{hr}$} & Influent & 1745 & 1733 & 1739 & 8.4853 \\
\hline & Midpoint & 143 & 129 & 136 & 9.8995 \\
\hline & Effluent & 67.1 & 55.7 & 61.4 & 8.0610 \\
\hline \multirow{3}{*}{$72 \mathrm{hr}$} & Influent & 1736 & 1724 & 1730 & 8.4853 \\
\hline & Midpoint & 177 & 165 & 171 & 8.4853 \\
\hline & Effluent & 160 & 148 & 154 & 8.4853 \\
\hline \multirow{3}{*}{$48 \mathrm{hr}$} & Influent & 1643 & 1655 & 1649 & 8.4853 \\
\hline & Midpoint & 167 & 157 & 162 & 7.0711 \\
\hline & Effluent & 157 & 143 & 150 & 9.8995 \\
\hline \multirow{3}{*}{$24 \mathrm{hr}$} & Influent & 1694 & 1682 & 1688 & 8.4853 \\
\hline & Midpoint & 204 & 210 & 207 & 4.2426 \\
\hline & Effluent & 150 & 158 & 154 & 5.6569 \\
\hline \multirow{3}{*}{$12 \mathrm{hr}$} & Influent & 1680 & 1696 & 1688 & 11.3137 \\
\hline & Midpoint & 223 & 233 & 228 & 7.0711 \\
\hline & Effluent & 194 & 180 & 187 & 9.8995 \\
\hline \multirow{3}{*}{$6 \mathrm{hr}$} & Influent & 1590 & 1608 & 1599 & 12.7279 \\
\hline & Midpoint & 277 & 263 & 270 & 9.8995 \\
\hline & Effluent & 215 & 209 & 212 & 4.2426 \\
\hline
\end{tabular}


Table B 4. Chemical Oxygen Demand Results-Phase IV

\begin{tabular}{|c|c|c|c|c|c|}
\hline HRT & Sample Port & Run 1 & Run 2 & $\begin{array}{l}\text { Average Value } \\
\text { (Run1 and Run } \\
\text { 2) }\end{array}$ & $\begin{array}{c}\text { Standard } \\
\text { Deviation (Run } 1 \\
\text { and Run 2) }\end{array}$ \\
\hline \multirow{3}{*}{$96 \mathrm{hr}$} & Influent & 638 & 652 & 645 & 9.8995 \\
\hline & Midpoint & 192 & 180 & 186 & 8.4853 \\
\hline & Effluent & 129 & 143 & 136 & 9.8995 \\
\hline \multirow{3}{*}{$72 \mathrm{hr}$} & Influent & 652 & 644 & 648 & 5.6569 \\
\hline & Midpoint & 232 & 246 & 239 & 9.8995 \\
\hline & Effluent & 159 & 169 & 164 & 7.0711 \\
\hline \multirow{3}{*}{$48 \mathrm{hr}$} & Influent & 650 & 638 & 644 & 8.4853 \\
\hline & Midpoint & 272 & 280 & 276 & 5.6569 \\
\hline & Effluent & 159 & 171 & 165 & 8.4853 \\
\hline \multirow{3}{*}{$24 \mathrm{hr}$} & Influent & 641 & 633 & 637 & 5.6569 \\
\hline & Midpoint & 258 & 270 & 264 & 8.4853 \\
\hline & Effluent & 173 & 161 & 167 & 8.4853 \\
\hline \multirow{3}{*}{$12 \mathrm{hr}$} & Influent & 626 & 638 & 632 & 8.4853 \\
\hline & Midpoint & 288 & 298 & 293 & 7.0711 \\
\hline & Effluent & 183 & 195 & 189 & 8.4853 \\
\hline \multirow{3}{*}{$6 \mathrm{hr}$} & Influent & 654 & 670 & 662 & 11.3137 \\
\hline & Midpoint & 338 & 350 & 344 & 8.4853 \\
\hline & Effluent & 190 & 208 & 199 & 12.7279 \\
\hline
\end{tabular}




\section{APPENDIX C- Gas Chromatograms for Calibration Curve}

Figure C 1. Gas Chromatogram -Standard 25 ppm Trial 1

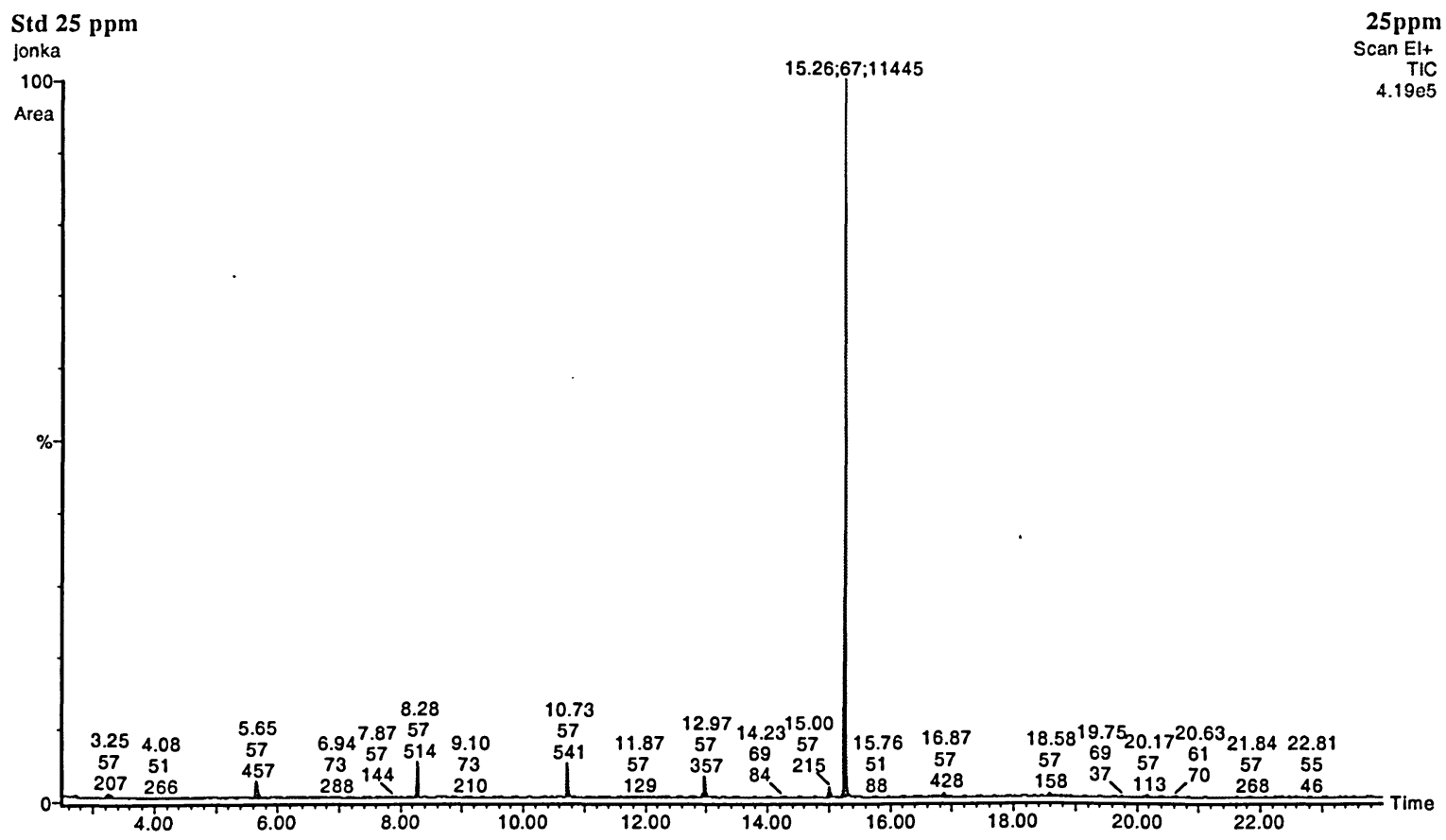

Figure C 2. Gas Chromatogram -Standard 25 ppm Trial 2

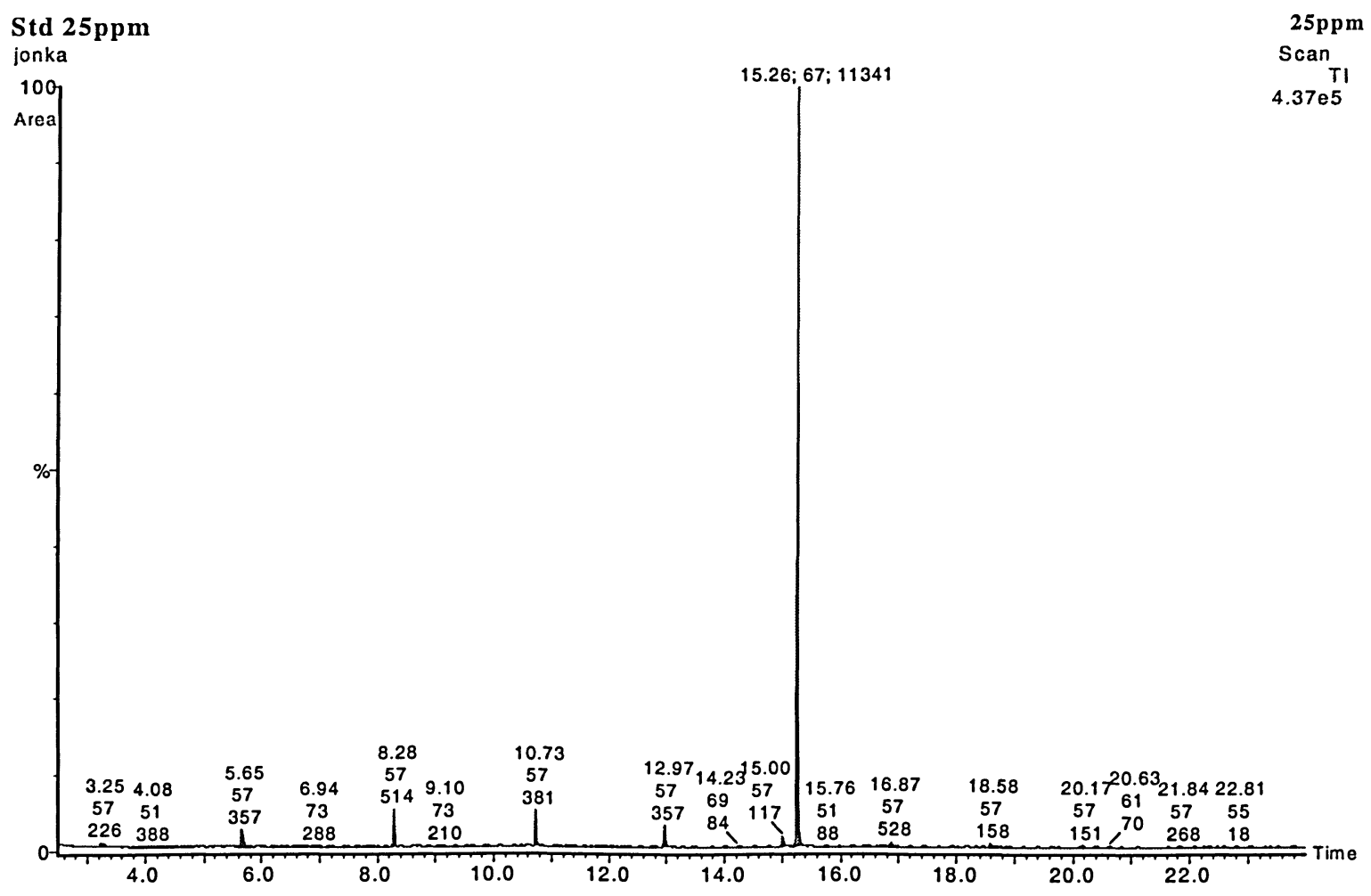


Figure C 3. Gas Chromatogram-Standard 50 ppm Trial 1

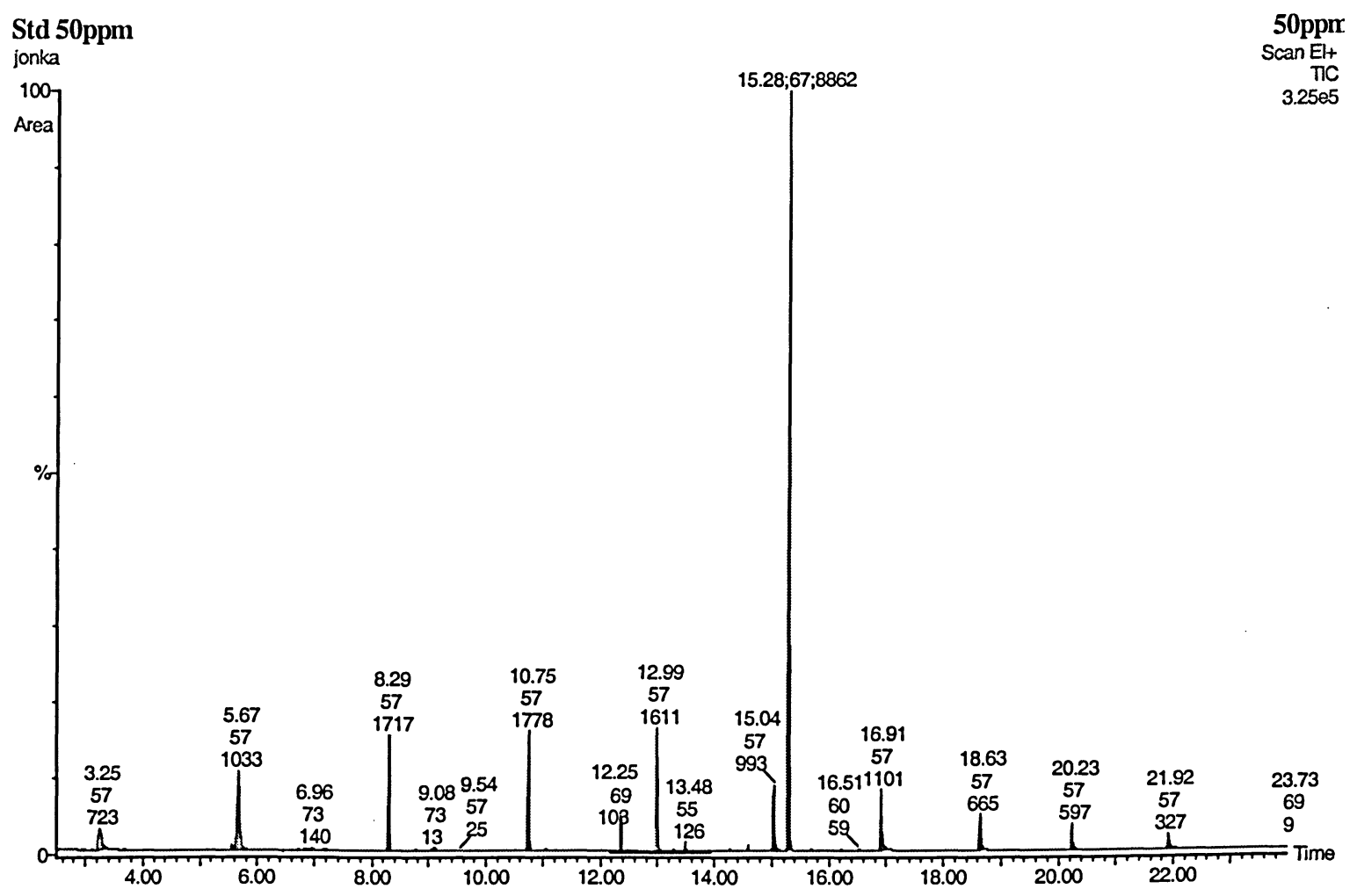

Figure C 4. Gas Chromatogram -Standard 50 ppm Trial 2

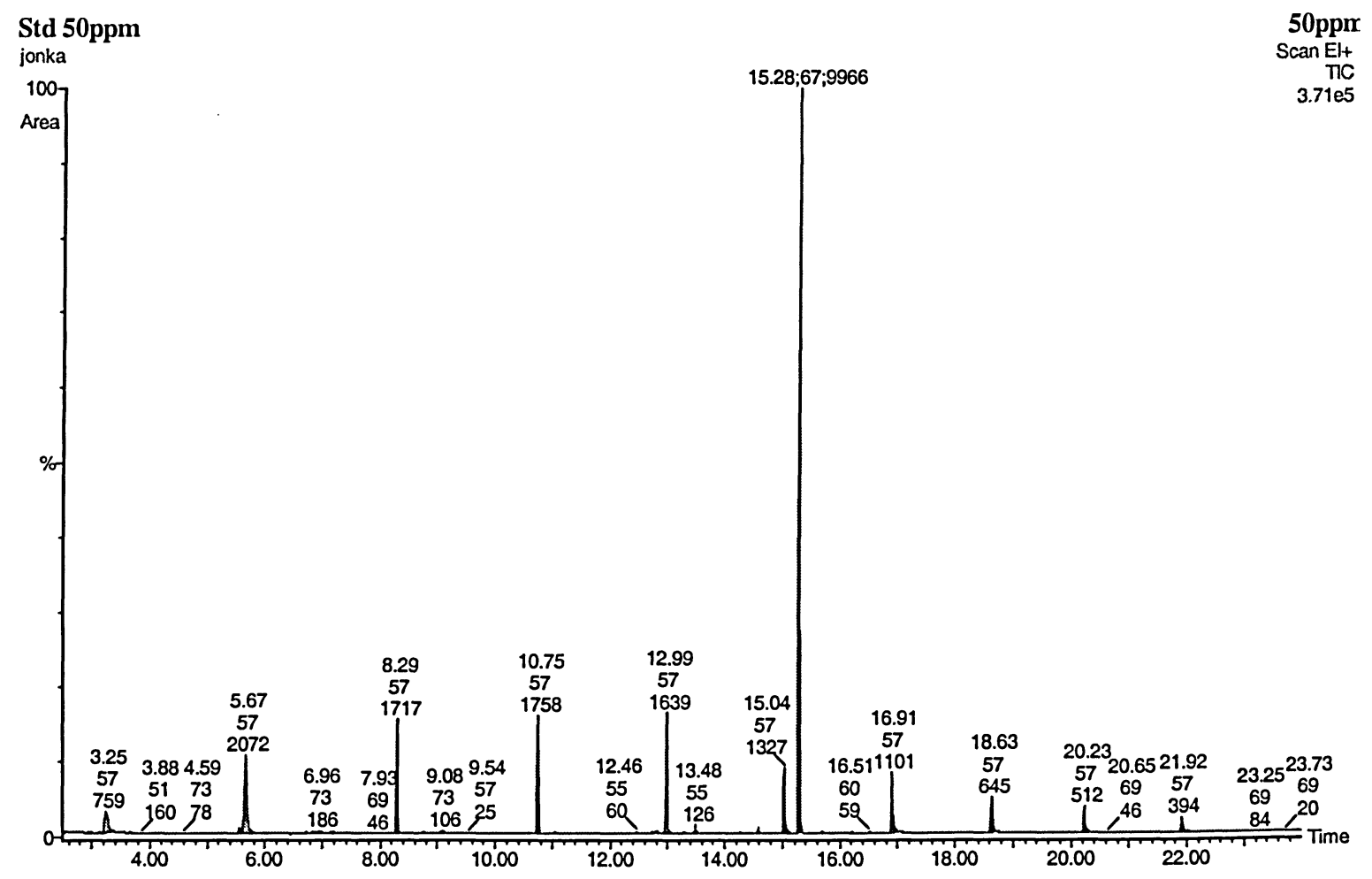


Figure C 5. Gas Chromatogram -Standard 100 ppm Diesel Trial 1

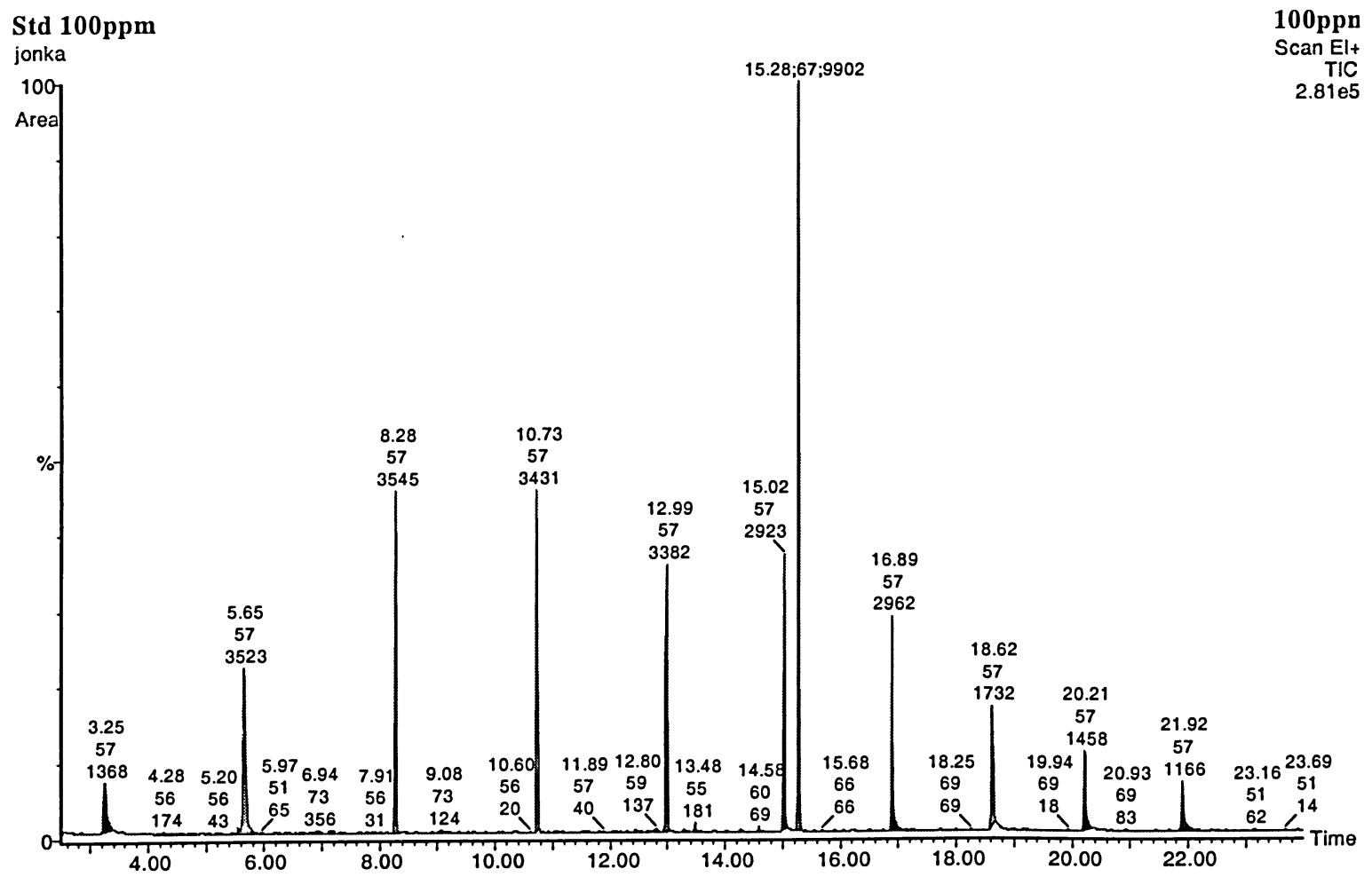

Figure C 6. Gas Chromatogram -Standard 100 ppm Diesel Trial 2

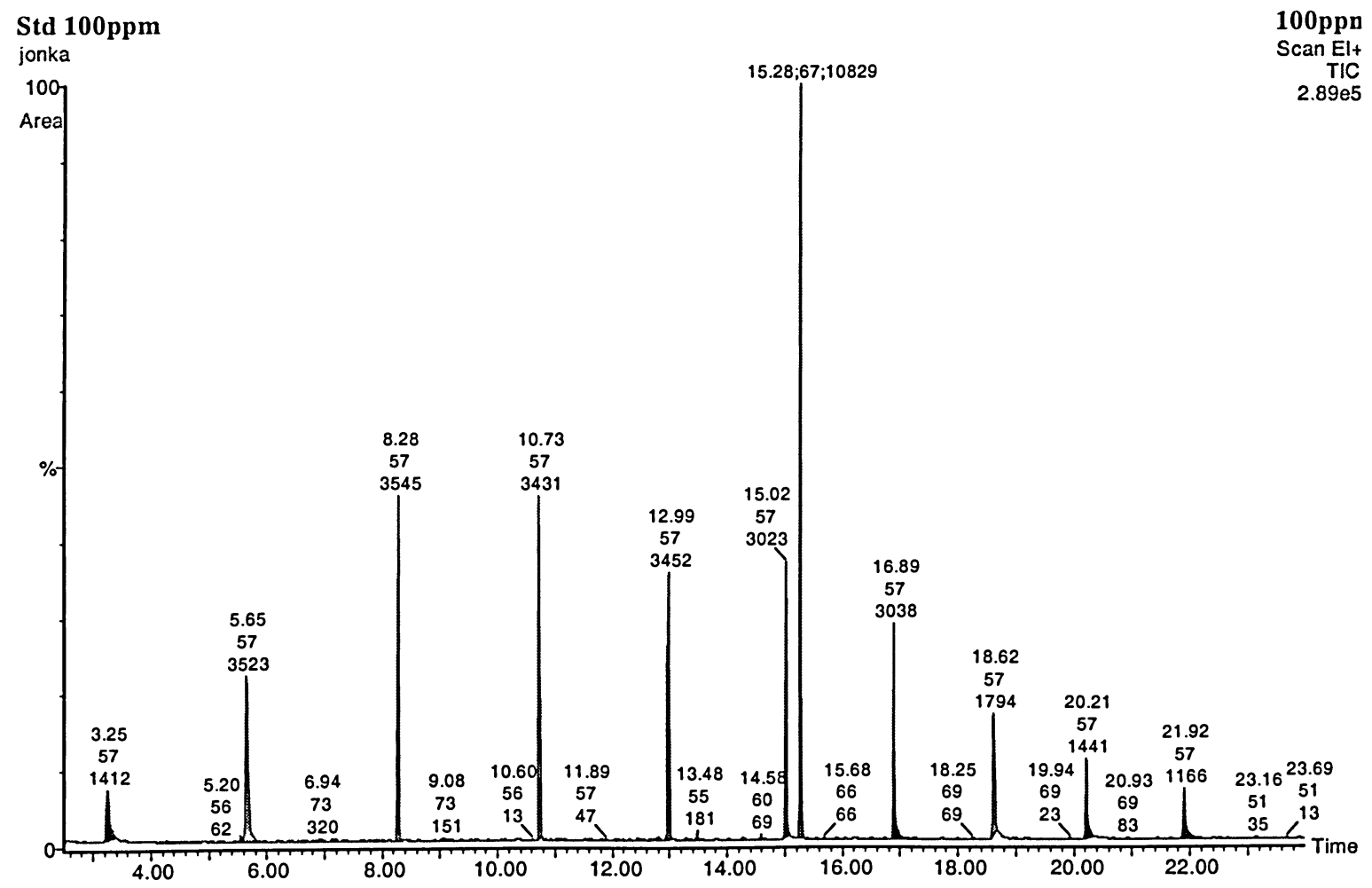


Figure C 7. Gas Chromatogram -Standard 200 ppm Diesel Trial 1

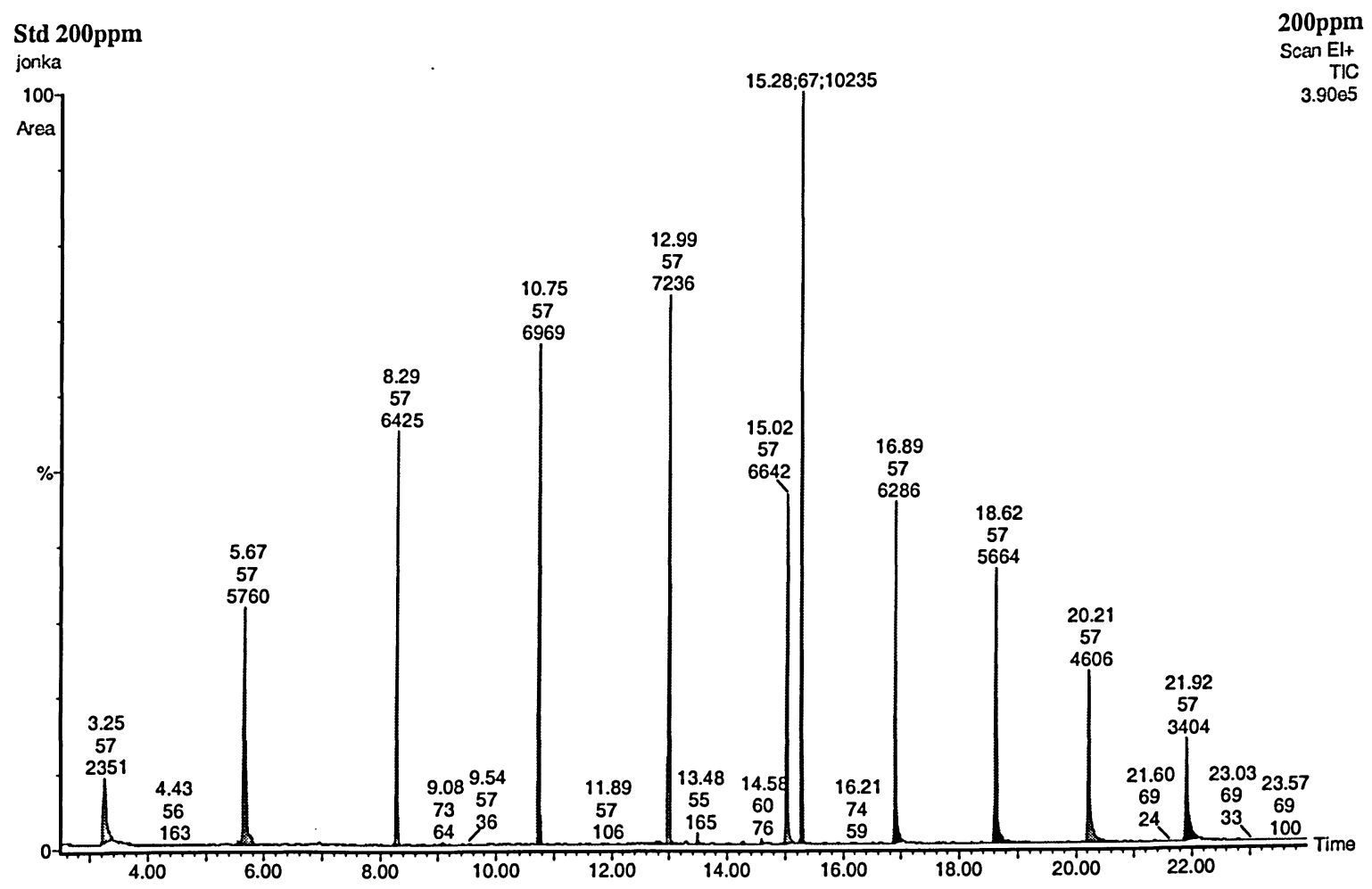

Figure C 8. Gas Chromatogram -Standard 200 ppm Diesel Trial 2

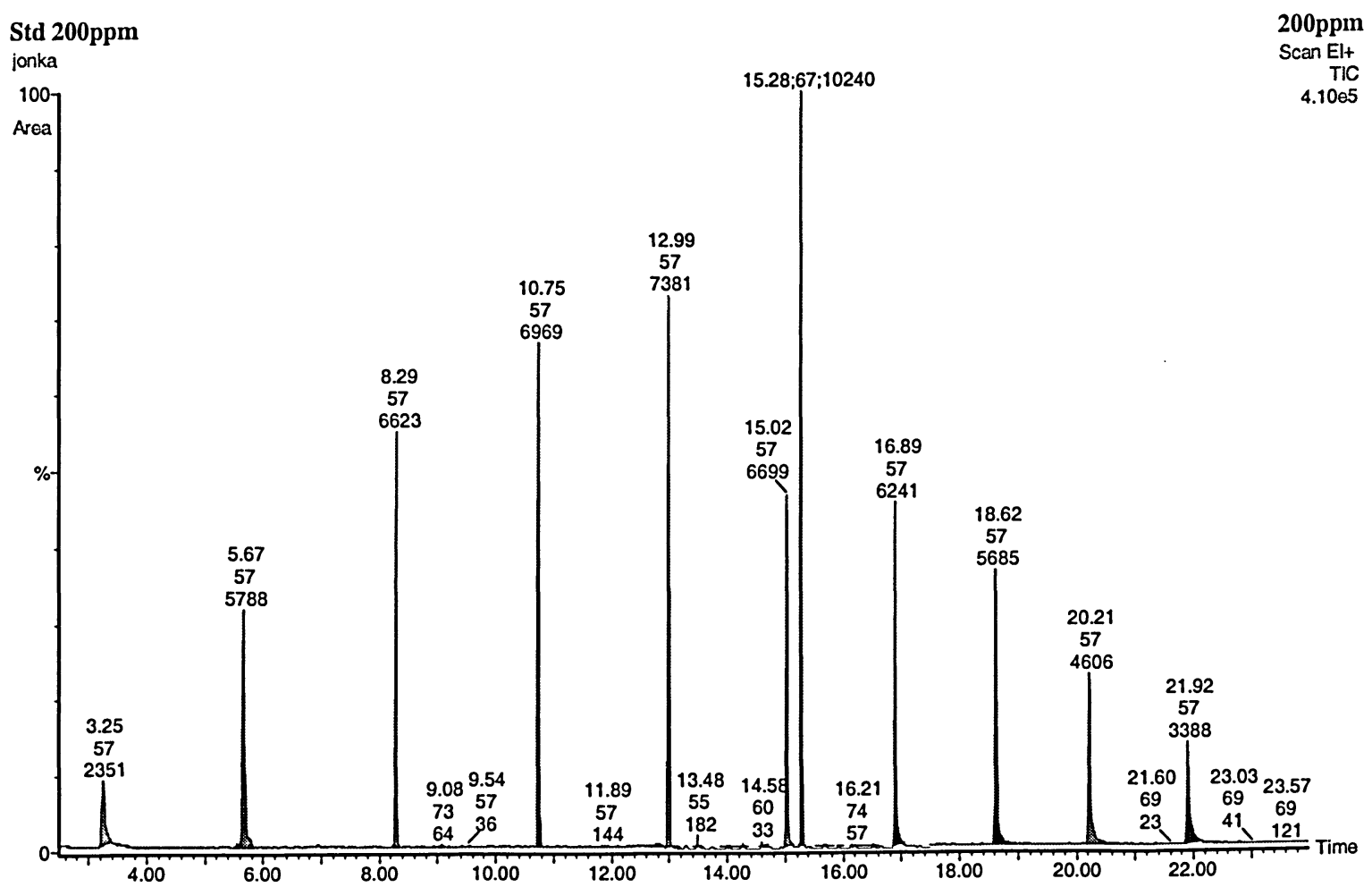


Figure C 9. Gas Chromatogram -Standard 250 ppm Diesel Trial 1

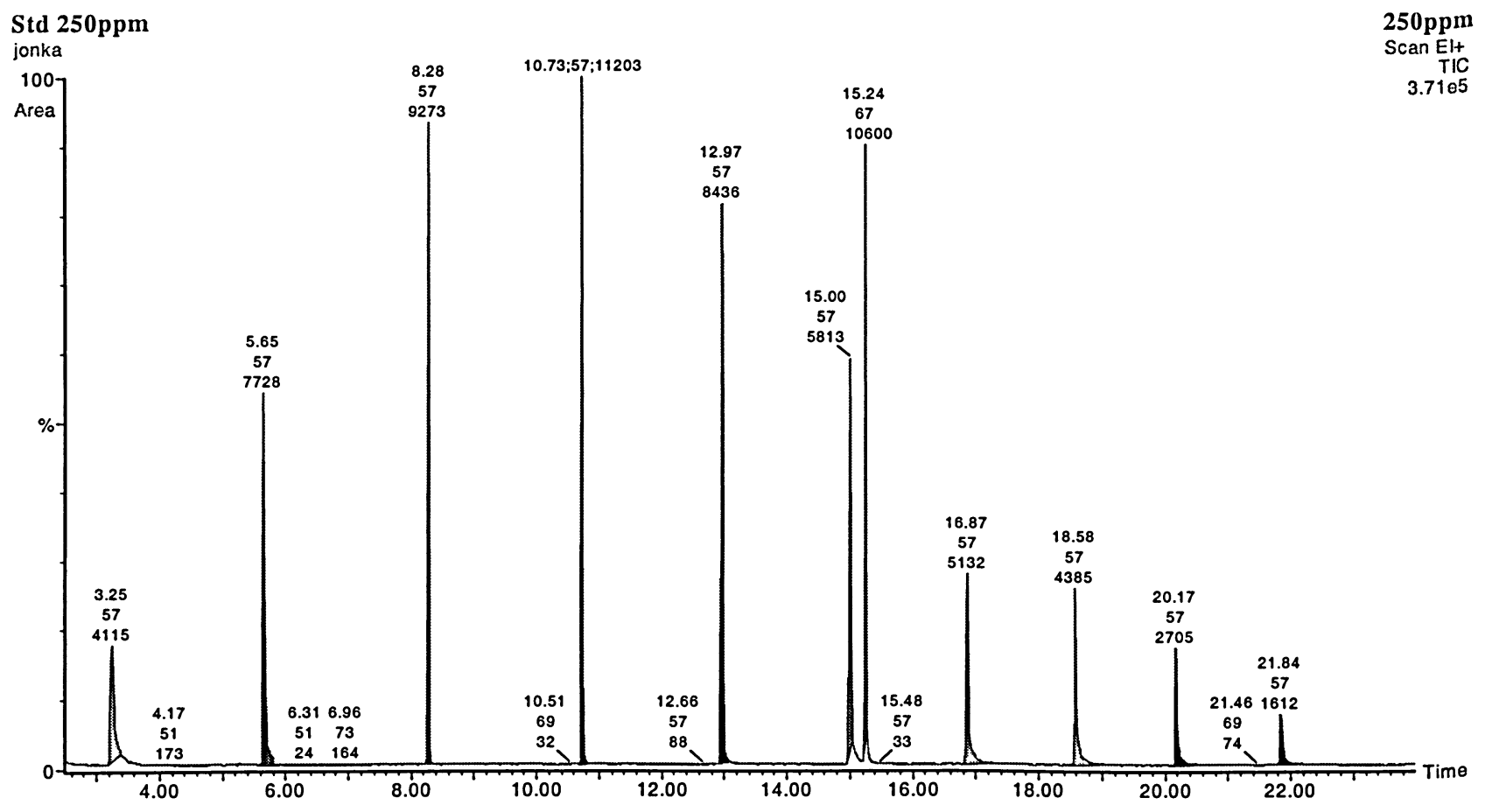

Figure C 10. Gas Chromatogram -Standard 250 ppm Diesel Trial 2

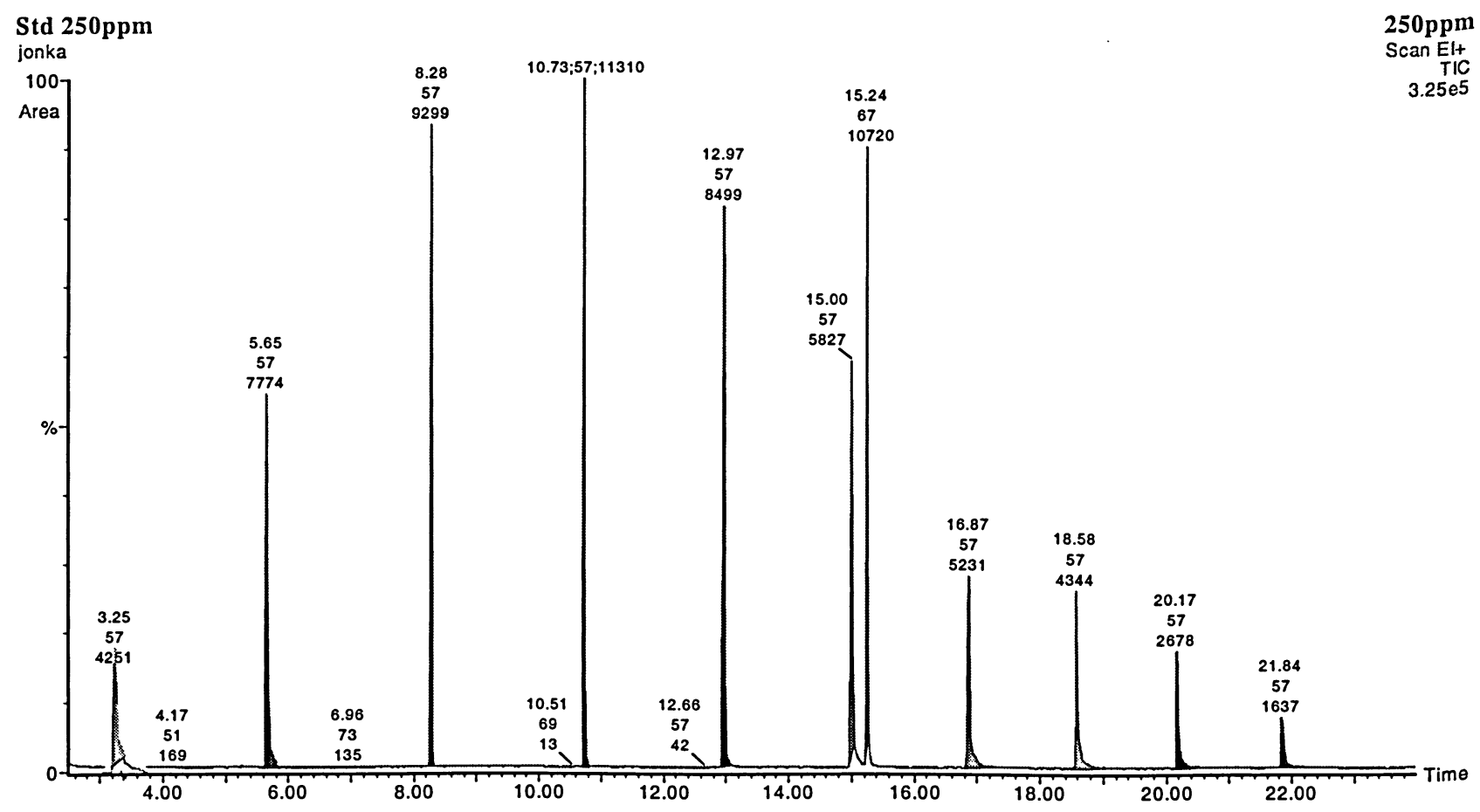


Figure C 11. Gas Chromatogram -Standard 300 ppm Diesel Trial 1

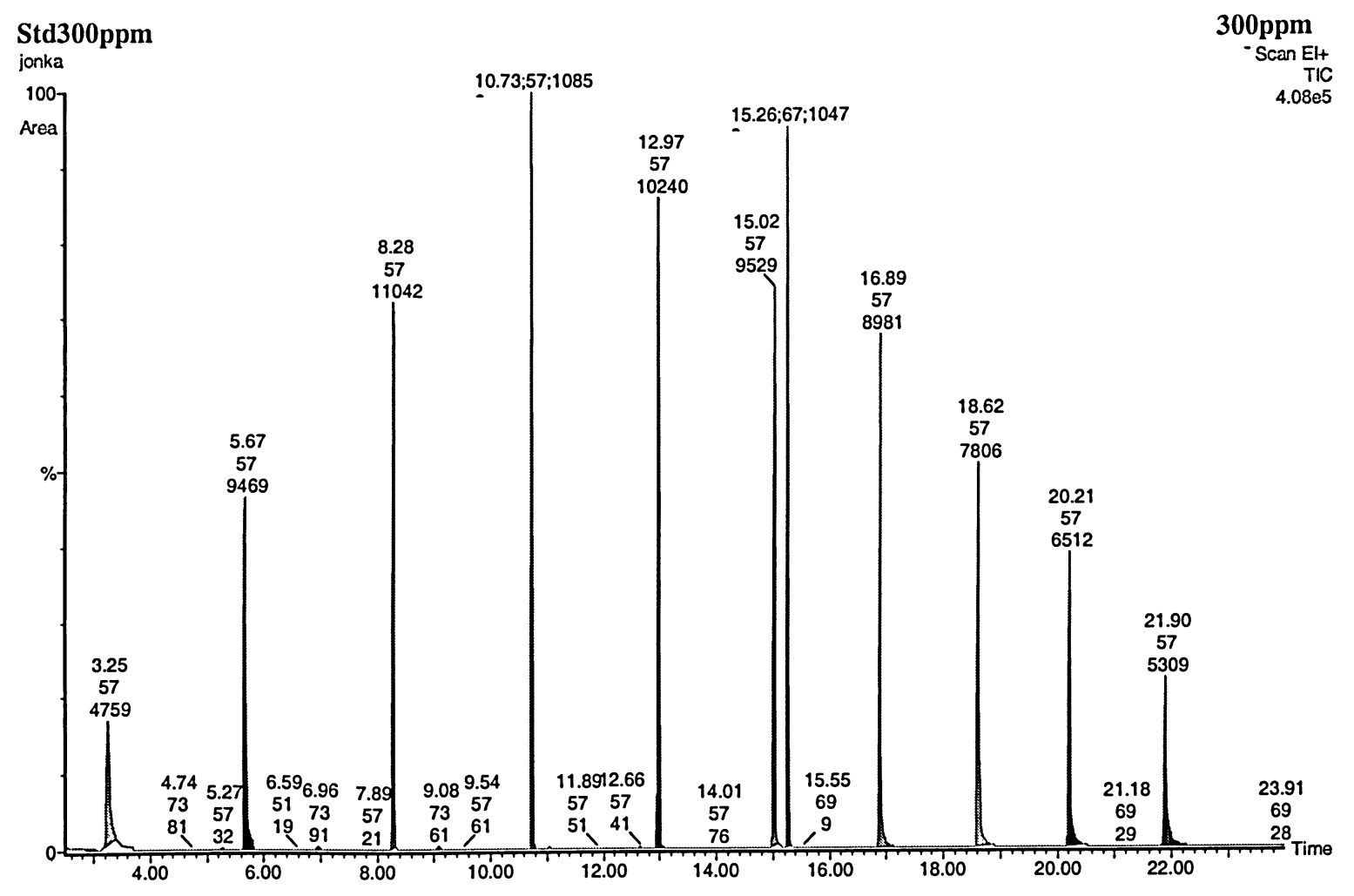

Figure C 12. Gas Chromatogram -Standard 300 ppm Diesel Trial 2

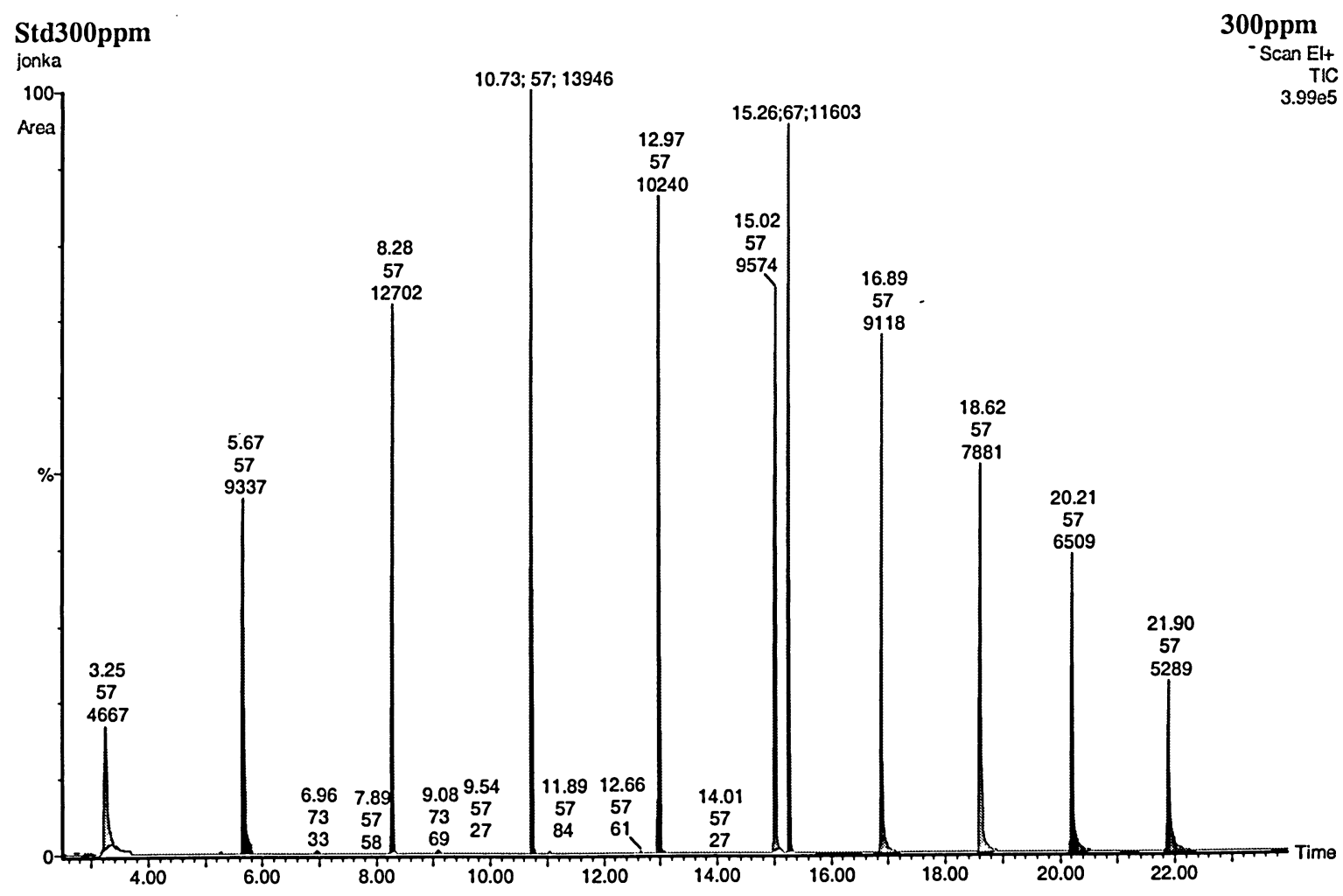


Figure C 13. Gas Chromatogram -Standard 400 ppm Diesel Trial 1

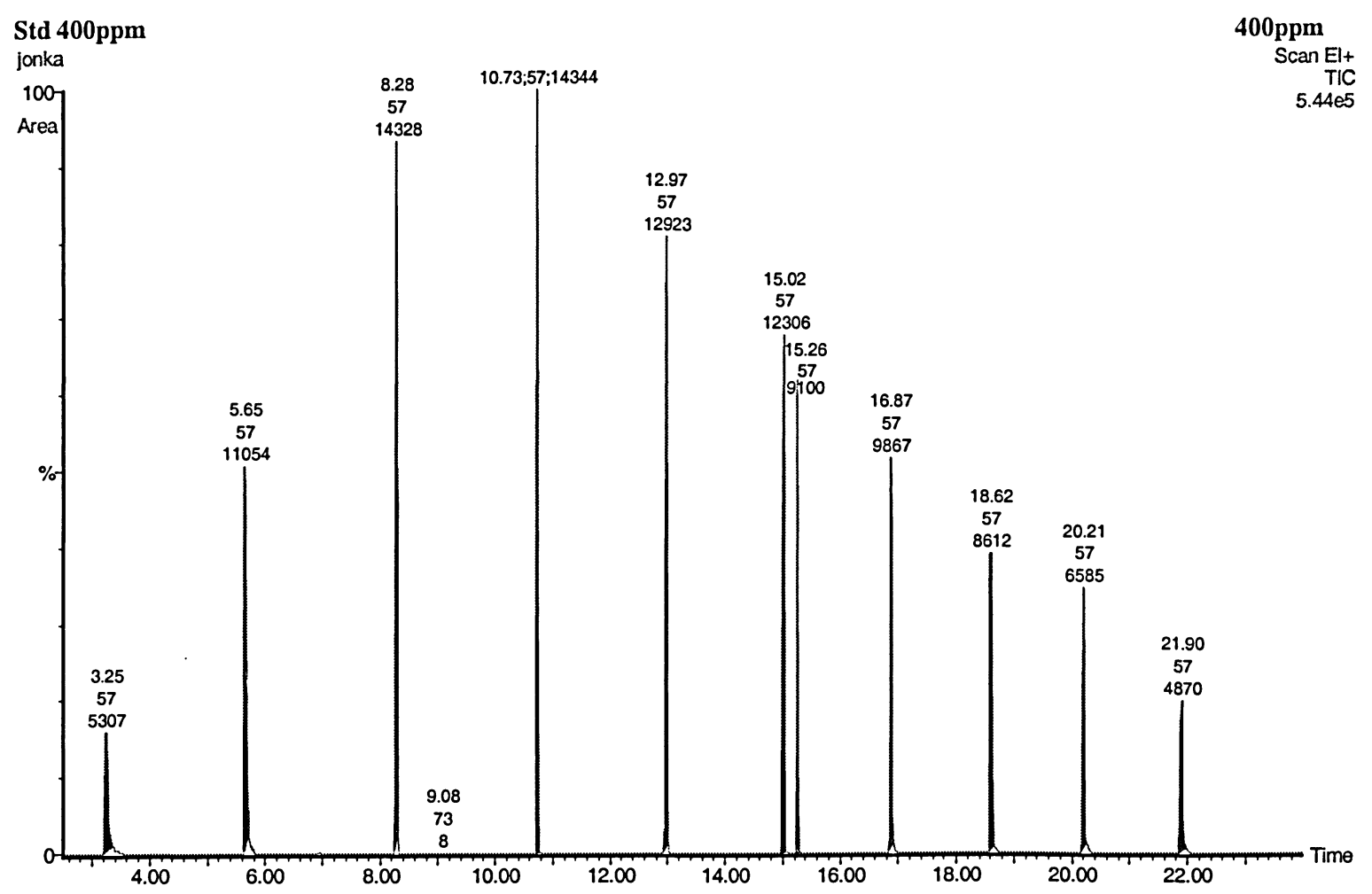

Figure C 14. Gas Chromatogram -Standard 400 ppm Diesel Trial 2

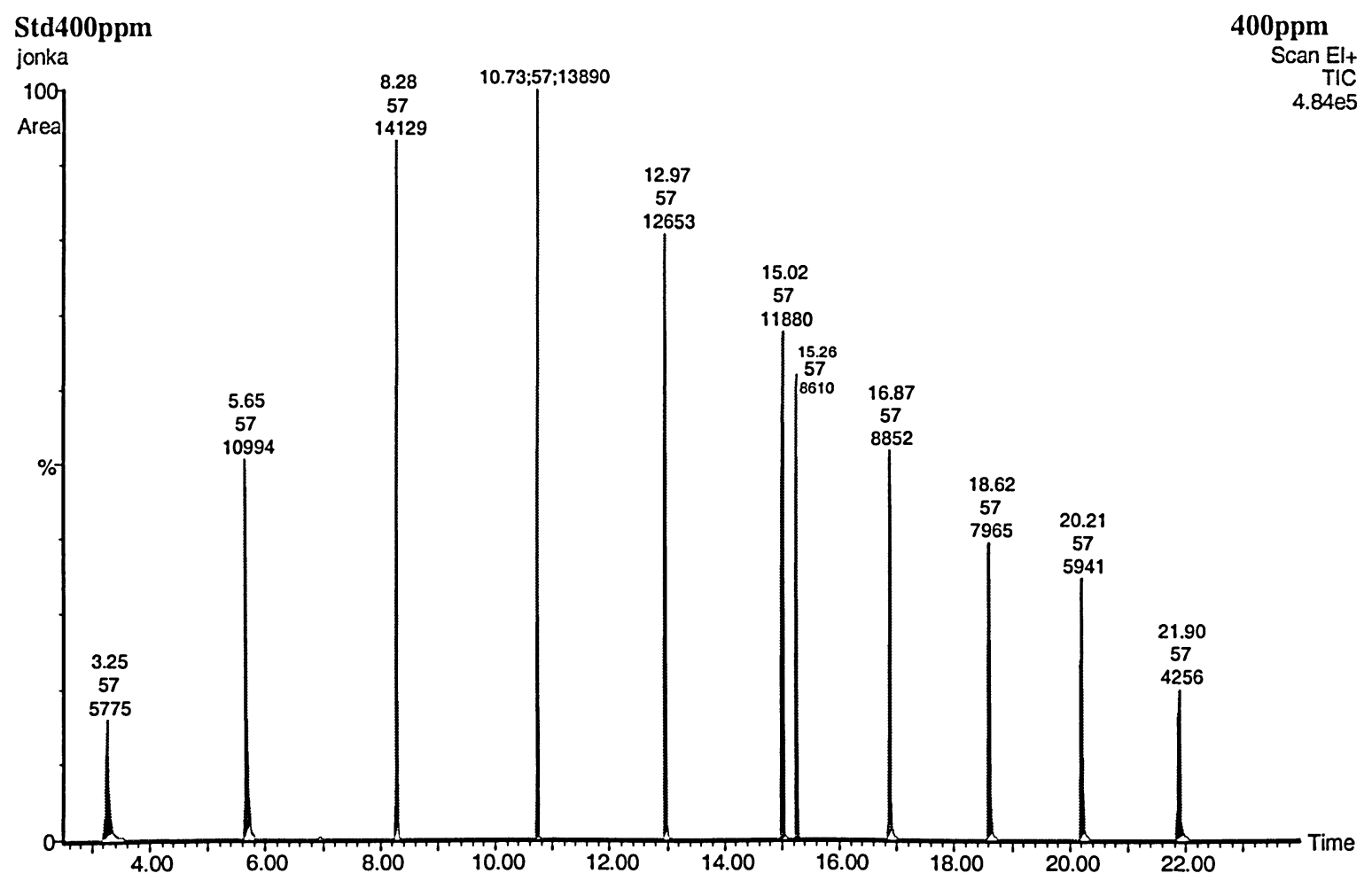


Figure C 15. Gas Chromatogram - Diesel Extracted Standard 25 ppm Trial 1

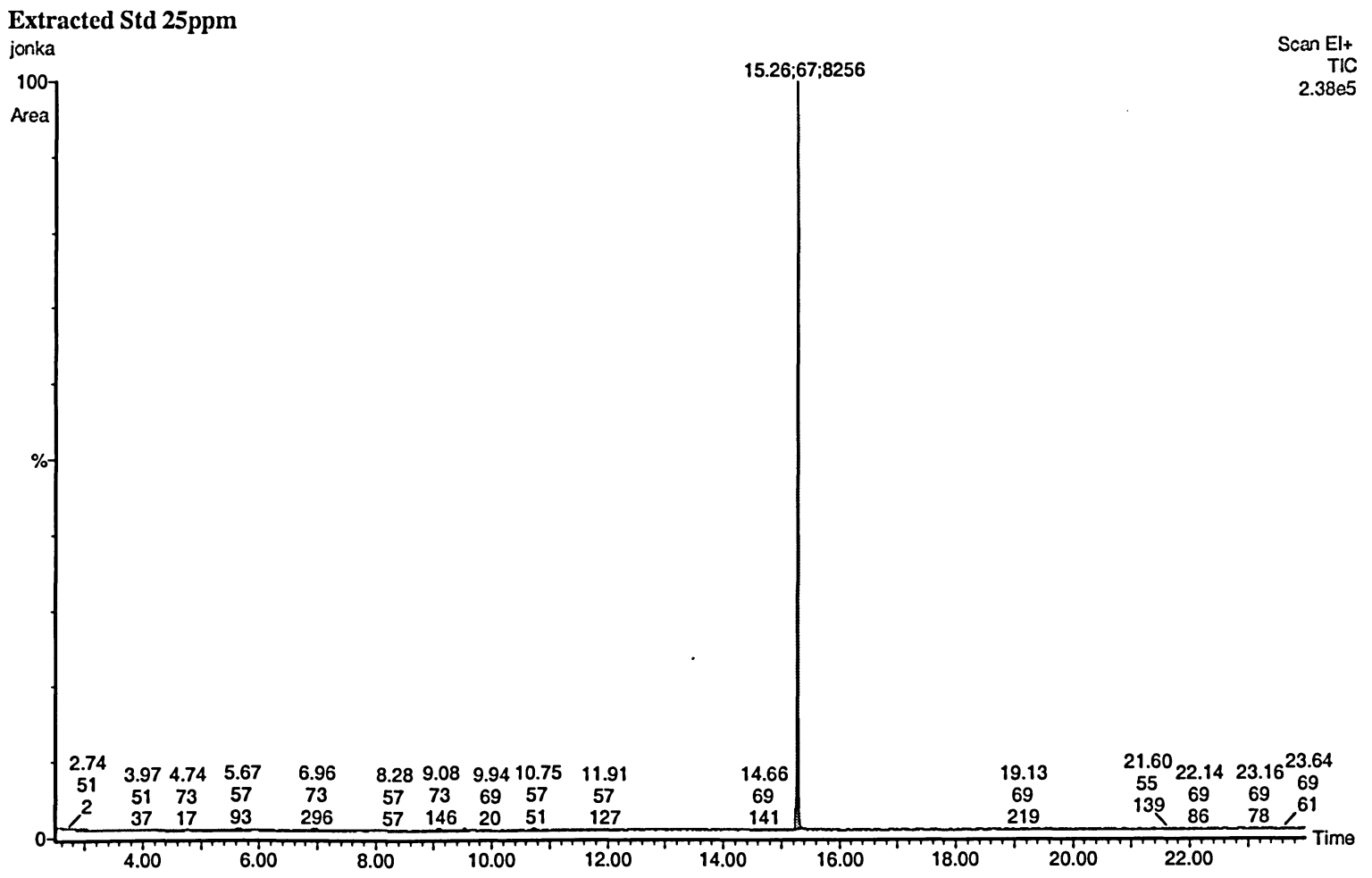

Figure C 16. Gas Chromatogram - Diesel Extracted Standard 25 ppm Trial 2

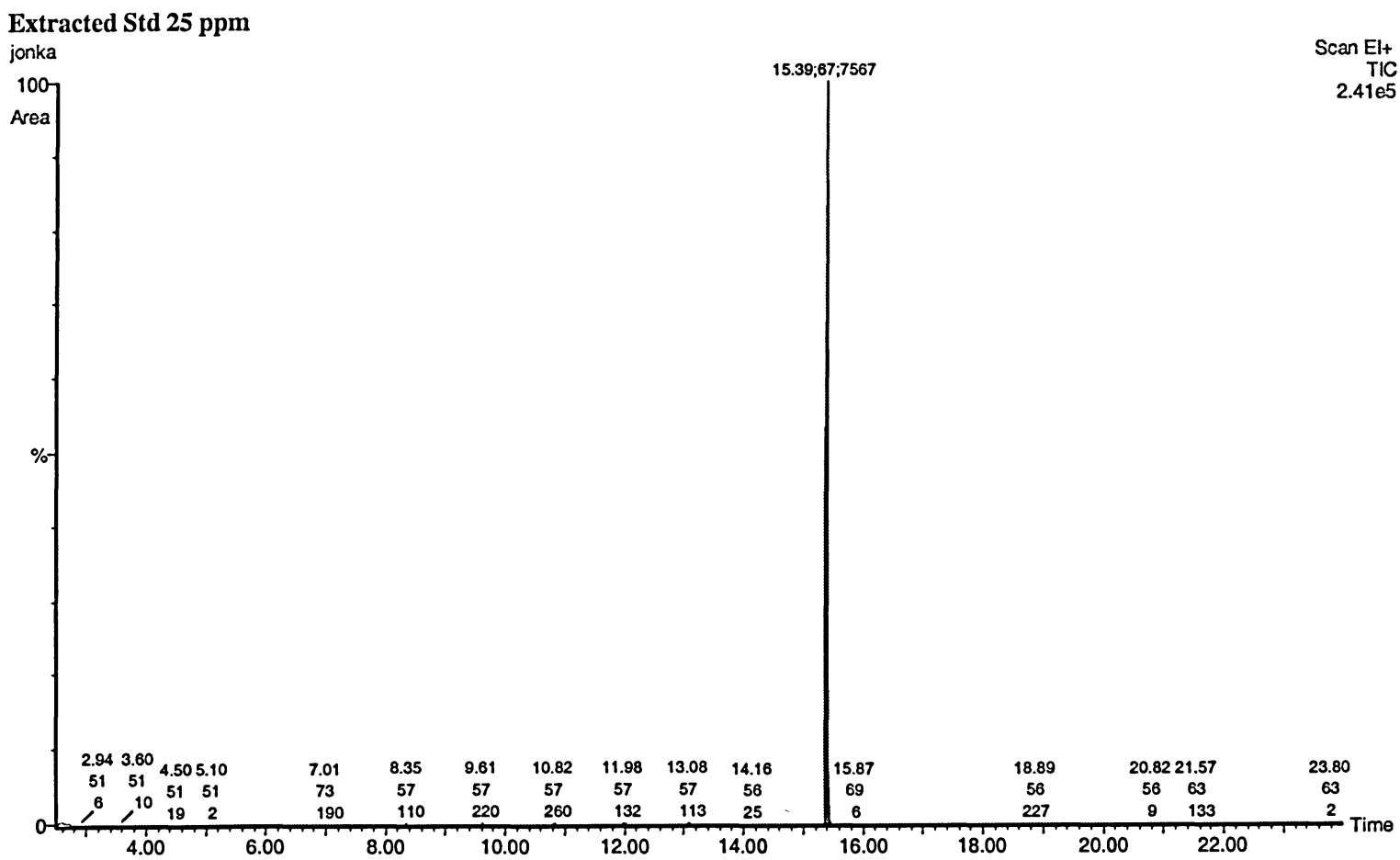


Figure C 17. Gas Chromatogram - Diesel Extracted Standard 50 ppm Trial 1

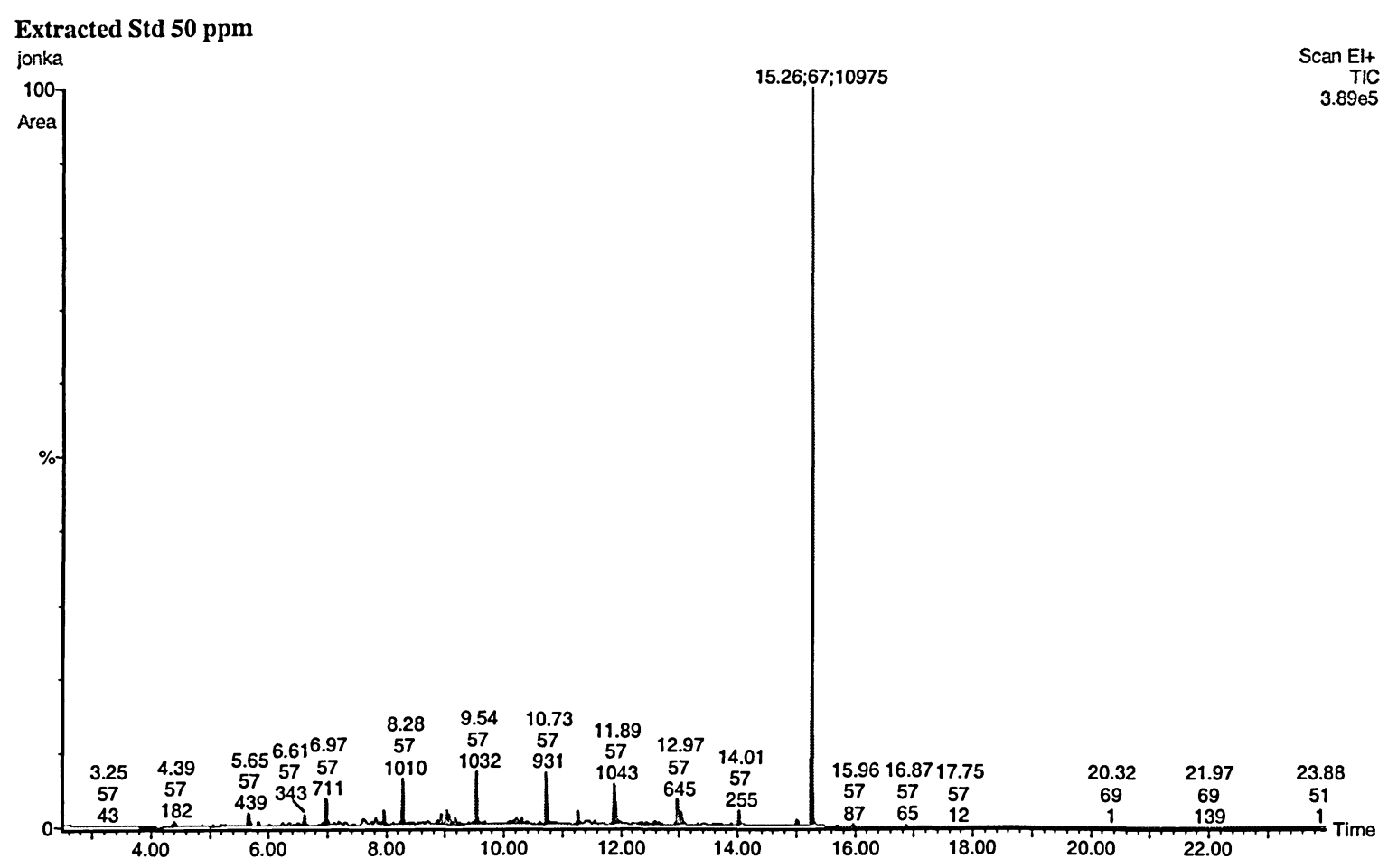

Figure C 18. Gas Chromatogram - Diesel Extracted Standard 50 ppm Trial 2

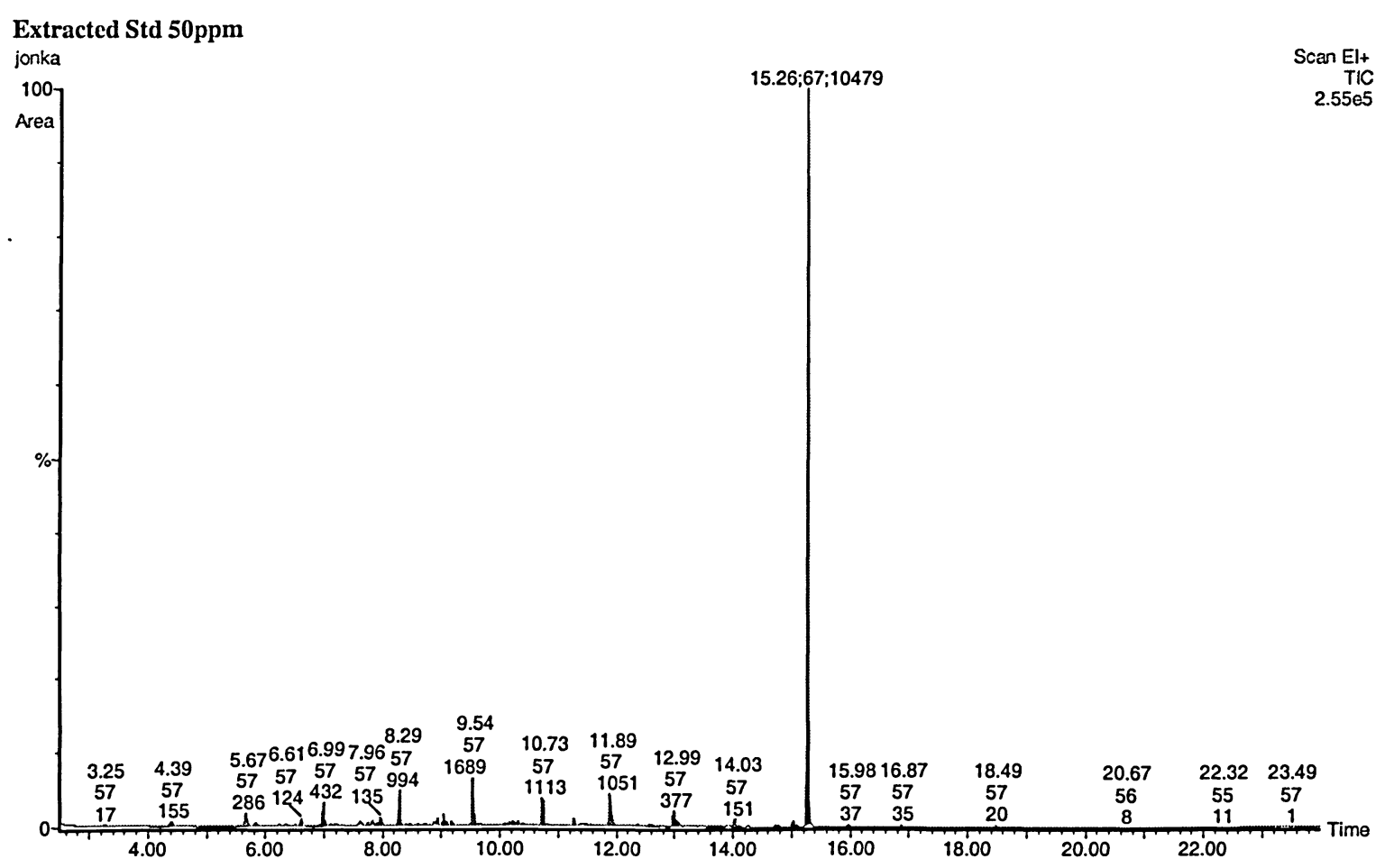


Figure C 19. Gas Chromatogram - Diesel Extracted Standard 100 ppm Trial 1

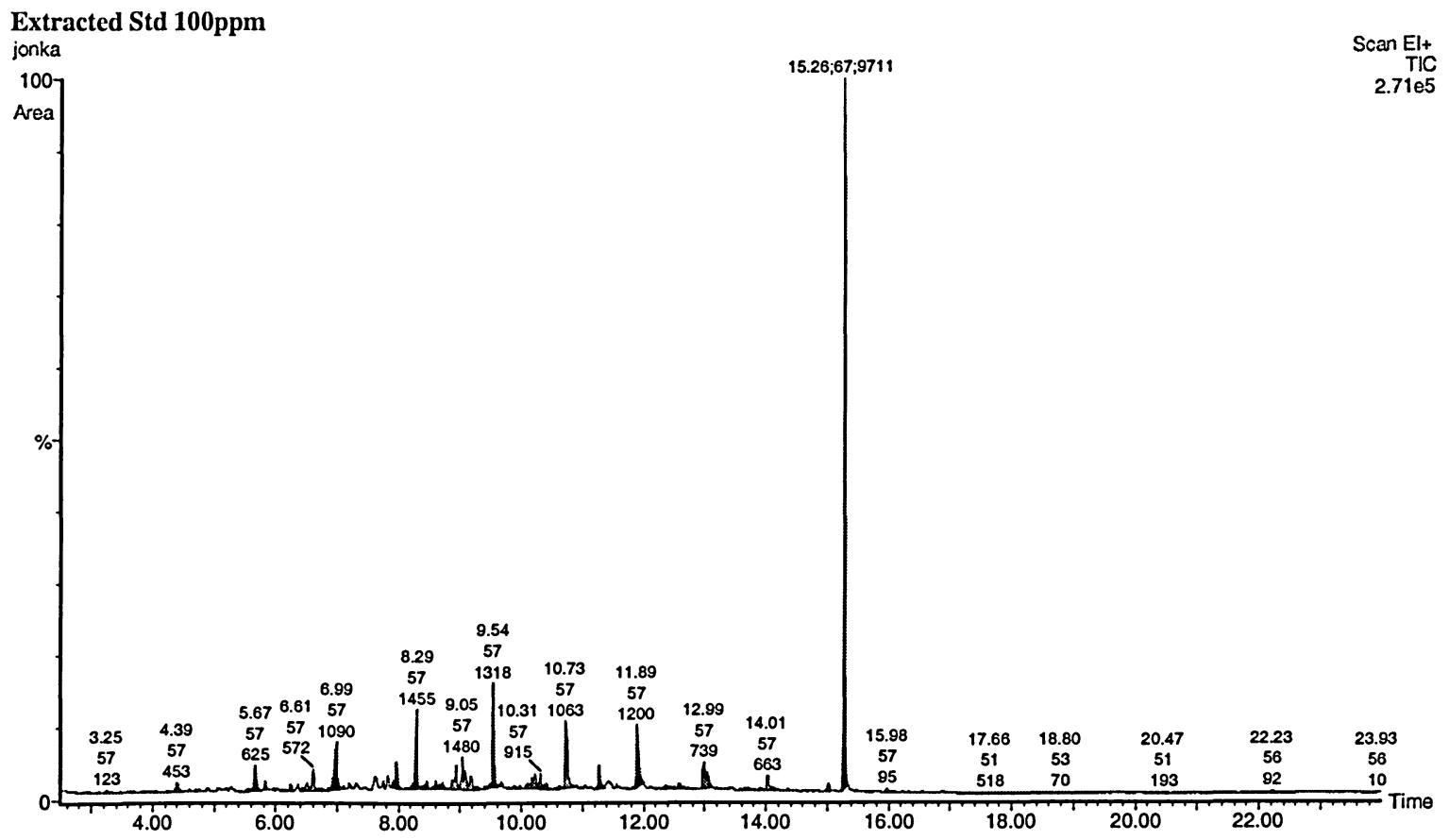

Figure C 20. Gas Chromatogram - Diesel Extracted Standard 100 ppm Trial 2

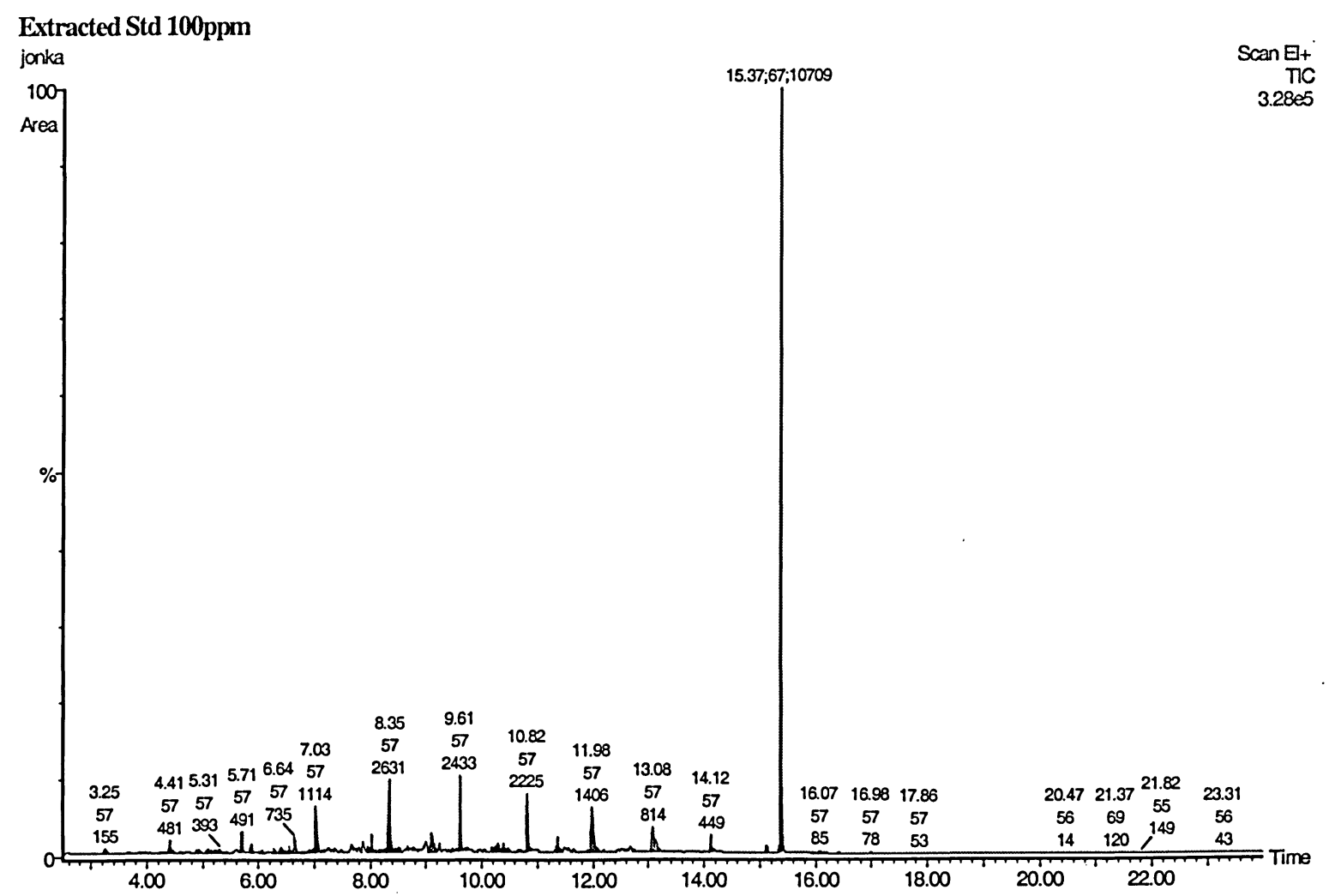


Figure C 21. Gas Chromatogram - Diesel Extracted Standard 200 ppm Trial 1

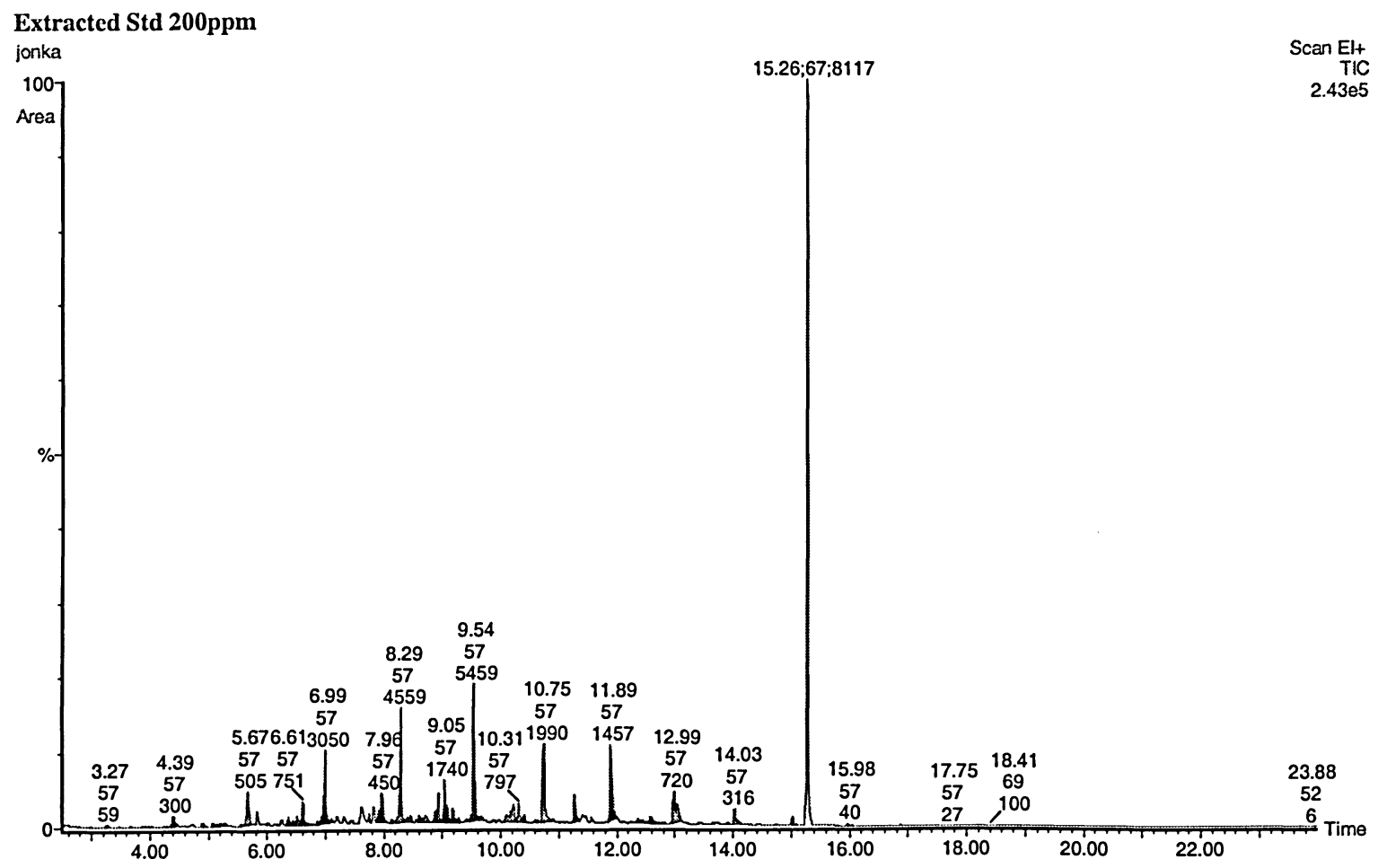

Figure C 22. Gas Chromatogram - Diesel Extracted Standard 200 ppm Trial 2

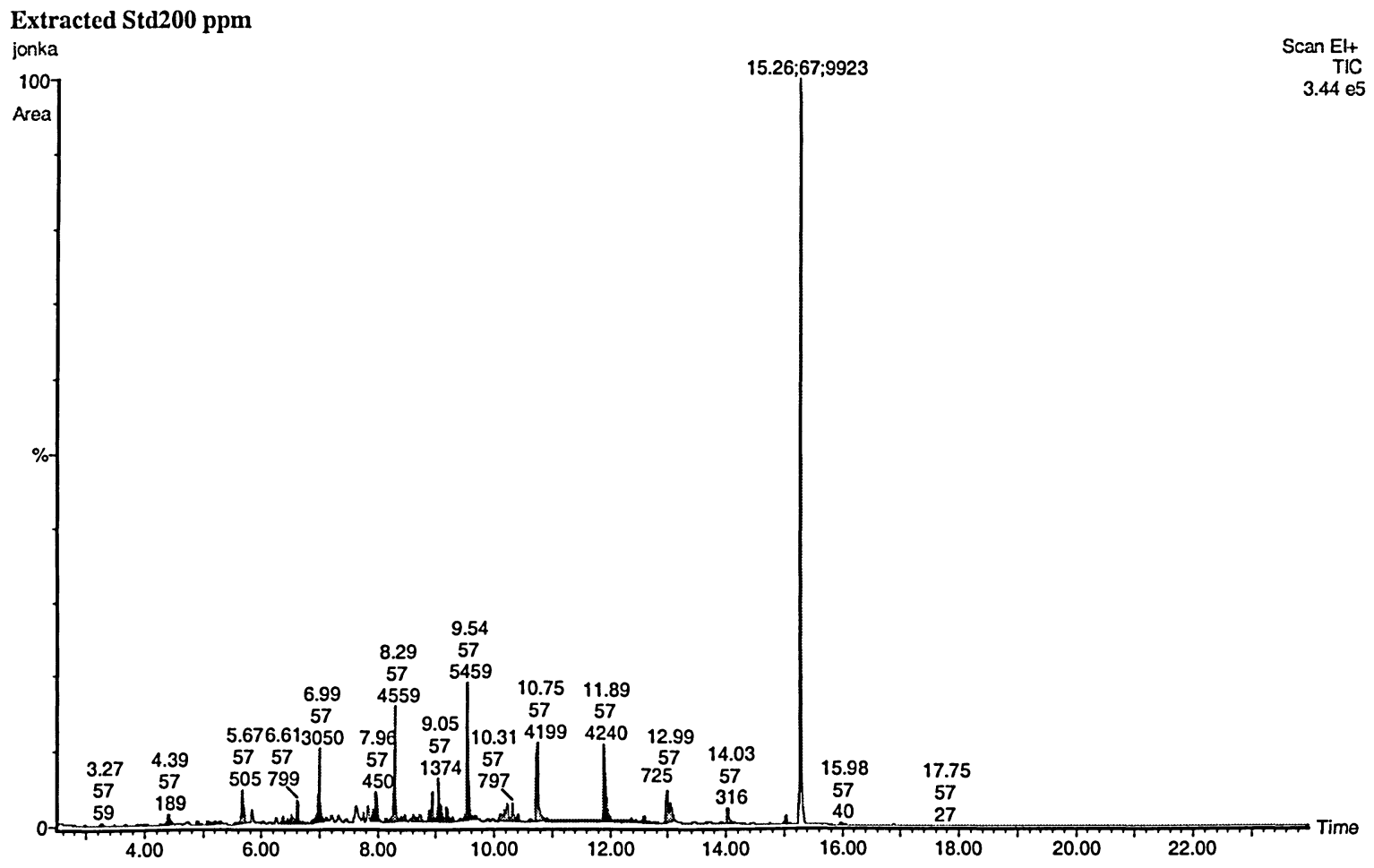


Figure C 23. Gas Chromatogram - Diesel Extracted Standard 250 ppm Trial 1

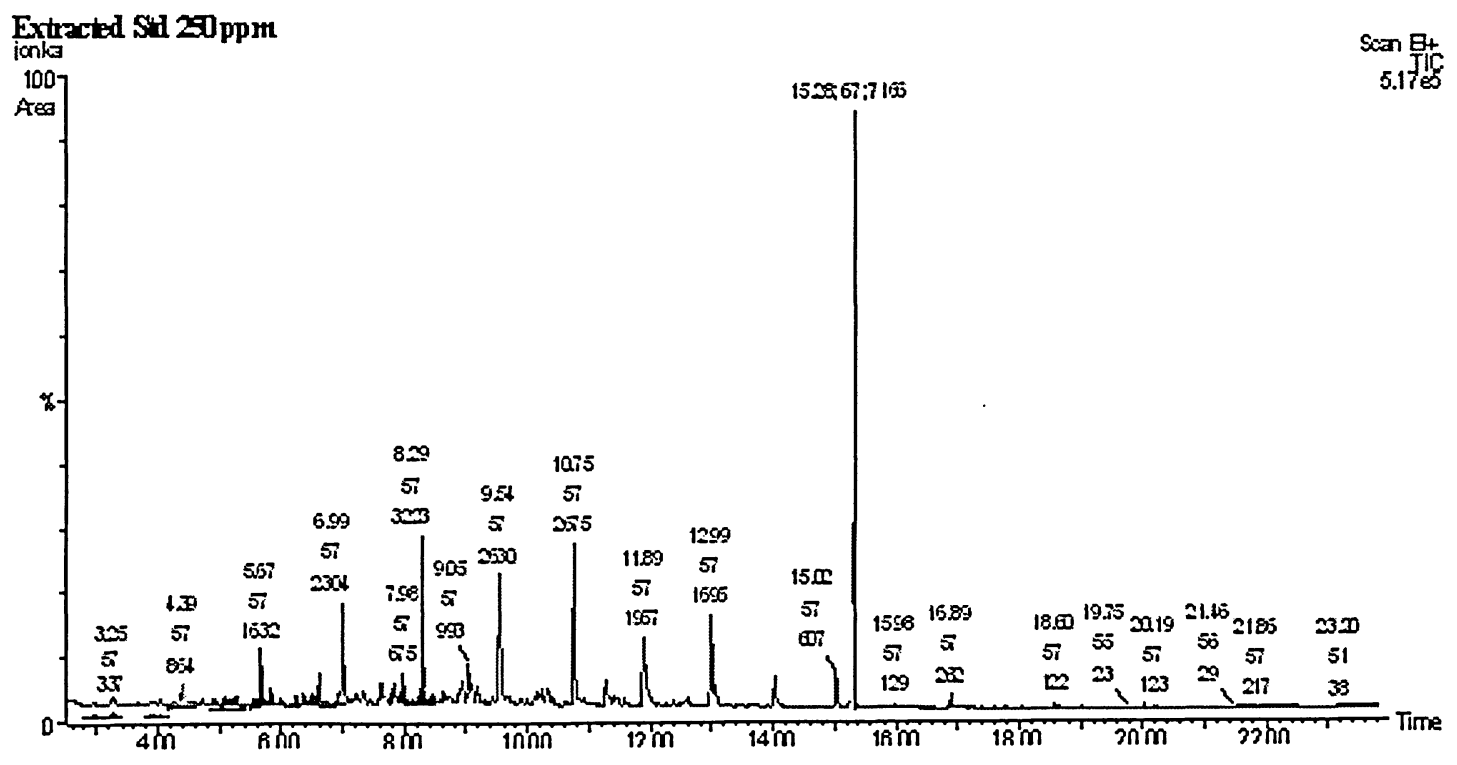

Figure C 24. Gas Chromatogram - Diesel Extracted Standard 250 ppm Trial 2

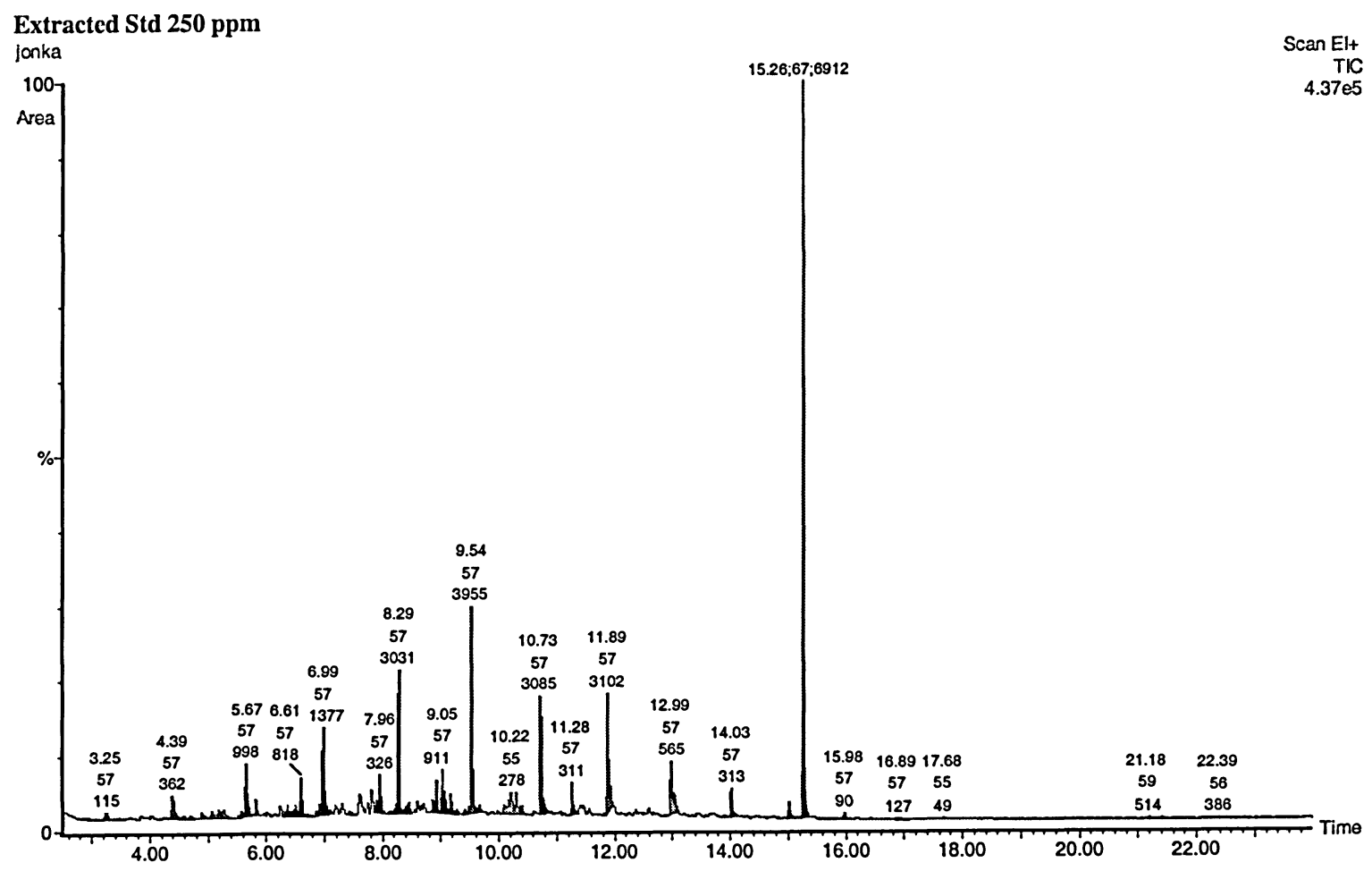


Figure C 25. Gas Chromatogram - Diesel Extracted Standard 300 ppm Trial 1

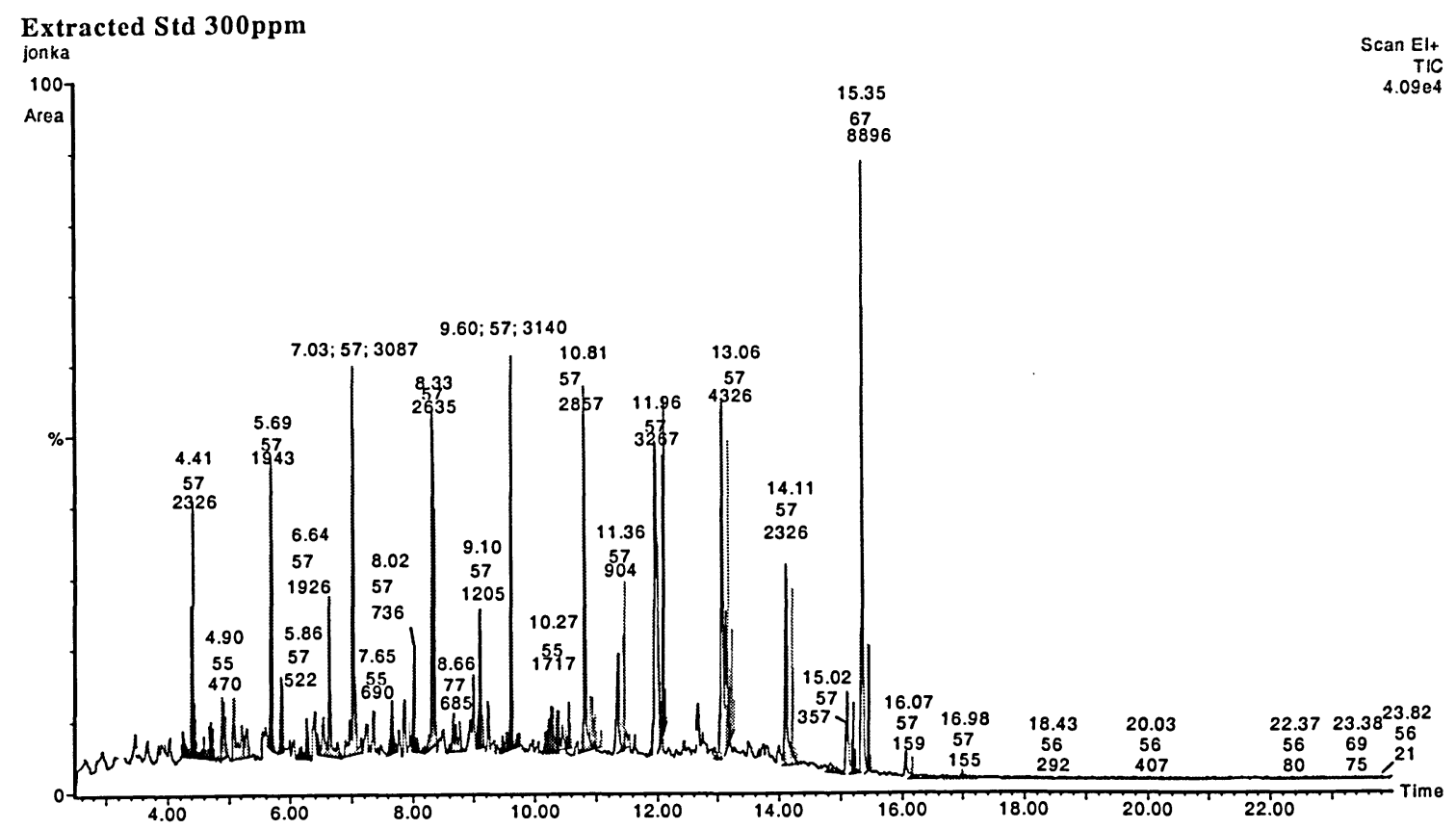

Figure C 26. Gas Chromatogram - Diesel Extracted Standard 300 ppm Trial 2

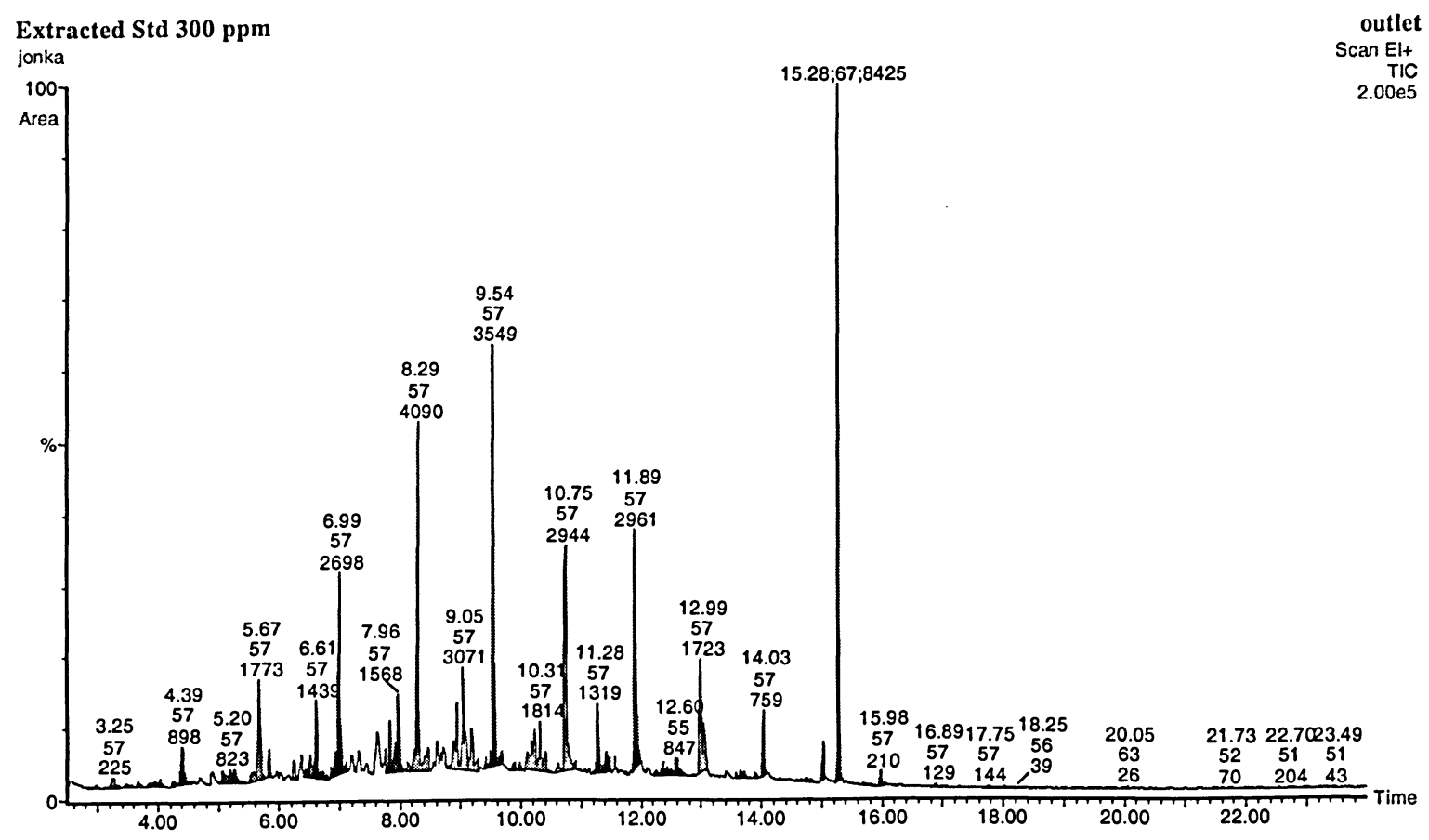


Figure C 27. Gas Chromatogram - Diesel Extracted Standard 400 ppm Trial 1

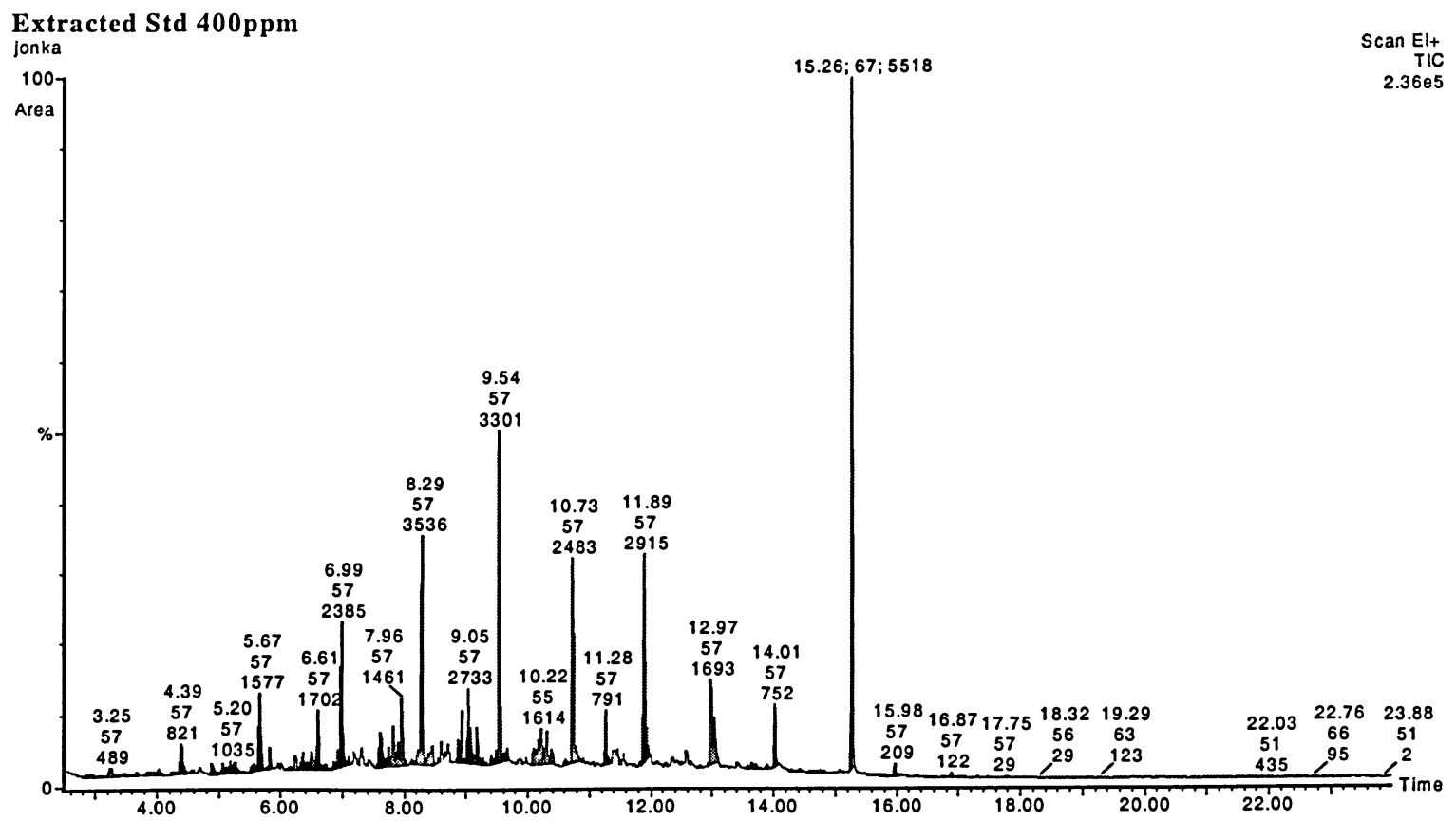

Figure C 28. Gas Chromatogram - Diesel Extracted Standard 400 ppm Trial 2

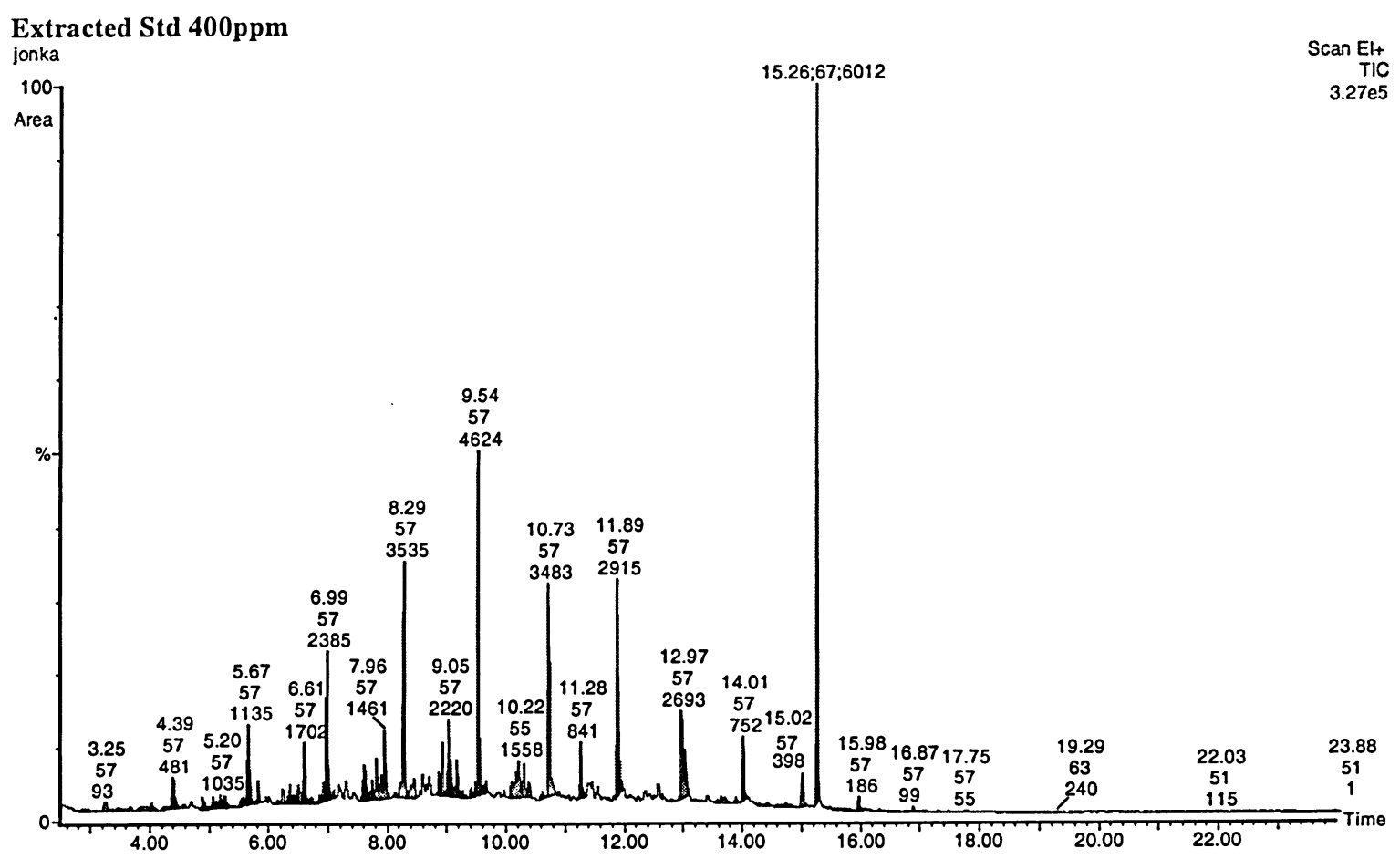




\section{APPENDIX D- Gas Chromatogram Values for Experimental Runs}

Table D 1. Gas Chromatogram Values for Experimental Runs, Phase I and Phase II

\begin{tabular}{|c|c|c|c|c|c|}
\hline Phase I & \multirow[t]{2}{*}{ Point } & \multicolumn{4}{|c|}{ Gas Chromatogram Diesel fuel Concentration, $\mathrm{mg} / \mathrm{L}$} \\
\hline HRT & & Run\#1 & Run\#2 & Average & Stdev \\
\hline \multirow[t]{3}{*}{$96 \mathrm{hr}$} & Inlet & 104.929 & 105.019 & 104.974 & 0.063 \\
\hline & Midpoint & 24.424 & 25.173 & 24.799 & 0.529 \\
\hline & Outlet & 22.556 & 23.653 & 23.104 & 0.776 \\
\hline \multirow[t]{3}{*}{$72 \mathrm{hr}$} & Inlet & 95.275 & 96.232 & 95.753 & 0.677 \\
\hline & Midpoint & 25.438 & 25.602 & 25.520 & 0.116 \\
\hline & Outlet & 25.273 & 25.278 & 25.275 & 0.003 \\
\hline \multirow[t]{3}{*}{$48 \mathrm{hr}$} & Inlet & 91.792 & 95.275 & 93.533 & 2.462 \\
\hline & Midpoint & 28.778 & 30.228 & 29.503 & 1.025 \\
\hline & Outlet & 24.872 & 25.082 & 24.977 & 0.148 \\
\hline \multirow[t]{3}{*}{$24 \mathrm{hr}$} & Inlet & 92.623 & 91.027 & 91.825 & 1.129 \\
\hline & Midpoint & 31.229 & 30.876 & 31.052 & 0.250 \\
\hline & Outlet & 26.340 & 25.225 & 25.782 & 0.788 \\
\hline \multirow[t]{3}{*}{$12 \mathrm{hr}$} & Inlet & 106.491 & 102.397 & 104.444 & 2.895 \\
\hline & Midpoint & 40.452 & 37.040 & 38.746 & 2.412 \\
\hline & Outlet & 32.927 & 30.277 & 31.602 & 1.874 \\
\hline \multirow[t]{3}{*}{$6 \mathrm{hr}$} & Inlet & 102.678 & 105.547 & 104.112 & 2.029 \\
\hline & Midpoint & 46.694 & 55.931 & 51.312 & 6.532 \\
\hline & Outlet & 38.359 & 47.780 & 43.079 & 6.676 \\
\hline Phase II & \multirow[t]{2}{*}{ Point } & \multicolumn{4}{|c|}{ Gas Chromatogram Diesel fuel concentration, $\mathrm{mg} / \mathrm{L}$} \\
\hline HRT & & Run\#1 & Run\#2 & Average & Stdev \\
\hline \multirow[t]{3}{*}{$96 \mathrm{hr}$} & Inlet & 204.312 & 203.567 & 203.939 & 0.527 \\
\hline & Midpoint & 26.238 & 23.731 & 24.985 & 1.773 \\
\hline & Outlet & 23.110 & 23.512 & 23.311 & 0.284 \\
\hline \multirow[t]{3}{*}{$72 \mathrm{hr}$} & Inlet & 205.493 & 209.427 & 207.460 & 2.782 \\
\hline & Midpoint & 25.371 & 25.689 & 25.530 & 0.225 \\
\hline & Outlet & 23.328 & 24.376 & 23.852 & 0.742 \\
\hline \multirow[t]{3}{*}{$48 \mathrm{hr}$} & Inlet & 188.206 & 191.583 & 189.895 & 2.388 \\
\hline & Midpoint & 25.863 & 24.851 & 25.357 & 0.716 \\
\hline & Outlet & 23.911 & 24.817 & 24.364 & 0.641 \\
\hline \multirow[t]{3}{*}{$24 \mathrm{hr}$} & Inlet & 198.821 & 196.627 & 197.724 & 1.552 \\
\hline & Midpoint & 27.719 & 27.865 & 27.792 & 0.103 \\
\hline & Outlet & 24.188 & 26.846 & 25.517 & 1.879 \\
\hline \multirow[t]{3}{*}{$12 \mathrm{hr}$} & Inlet & 190.047 & 189.742 & 189.895 & 0.216 \\
\hline & Midpoint & 25.724 & 26.113 & 25.919 & 0.275 \\
\hline & Outlet & 25.219 & 24.872 & 25.046 & 0.246 \\
\hline \multirow[t]{3}{*}{$6 \mathrm{hr}$} & Inlet & 200.715 & 203.589 & 202.152 & 2.032 \\
\hline & Midpoint & 64.639 & 62.999 & 63.819 & 1.159 \\
\hline & Outlet & 38.827 & 38.569 & 38.698 & 0.183 \\
\hline
\end{tabular}


Table D 2. Gas Chromatogram Values for Experimental Runs, Phase III and Phase IV

\begin{tabular}{|c|c|c|c|c|c|}
\hline Phase III & \multirow[t]{2}{*}{ Point } & \multicolumn{4}{|c|}{ Gas Chromatogram Diesel fuel concentration, $\mathrm{mg} / \mathrm{L}$} \\
\hline HRT & & Run\#1 & Run\#2 & Average & Stdev \\
\hline $96 \mathrm{hr}$ & $\begin{array}{l}\text { Inlet } \\
\text { Midpoint } \\
\text { Outlet }\end{array}$ & $\begin{array}{c}293.336 \\
49.066 \\
23.327\end{array}$ & $\begin{array}{c}292.167 \\
27.074 \\
24.567\end{array}$ & $\begin{array}{c}292.752 \\
38.070 \\
23.947\end{array}$ & $\begin{array}{c}0.826 \\
15.551 \\
0.877 \\
\end{array}$ \\
\hline $72 \mathrm{hr}$ & $\begin{array}{l}\text { Inlet } \\
\text { Midpoint } \\
\text { Outlet }\end{array}$ & $\begin{array}{c}298.380 \\
58.246 \\
30.320\end{array}$ & $\begin{array}{c}297.402 \\
58.770 \\
34.298\end{array}$ & $\begin{array}{c}297.891 \\
58.508 \\
32.309\end{array}$ & $\begin{array}{l}0.691 \\
0.371 \\
2.813\end{array}$ \\
\hline $48 \mathrm{hr}$ & $\begin{array}{l}\text { Inlet } \\
\text { Midpoint } \\
\text { Outlet }\end{array}$ & $\begin{array}{c}295.476 \\
37.826 \\
34.302\end{array}$ & $\begin{array}{c}291.972 \\
44.084 \\
33.358\end{array}$ & $\begin{array}{c}293.724 \\
40.955 \\
33.830\end{array}$ & $\begin{array}{l}2.478 \\
4.425 \\
0.668 \\
\end{array}$ \\
\hline $24 \mathrm{hr}$ & $\begin{array}{l}\text { Inlet } \\
\text { Midpoint } \\
\text { Outlet }\end{array}$ & $\begin{array}{c}293.531 \\
57.509 \\
26.650\end{array}$ & $\begin{array}{c}290.006 \\
51.110 \\
46.623\end{array}$ & $\begin{array}{c}291.769 \\
54.309 \\
36.636\end{array}$ & $\begin{array}{r}2.492 \\
4.525 \\
14.123 \\
\end{array}$ \\
\hline $12 \mathrm{hr}$ & $\begin{array}{l}\text { Inlet } \\
\text { Midpoint } \\
\text { Outlet }\end{array}$ & $\begin{array}{c}289.992 \\
49.489 \\
39.489\end{array}$ & $\begin{array}{c}292.155 \\
74.745 \\
44.229 \\
\end{array}$ & $\begin{array}{c}291.073 \\
62.117 \\
41.859\end{array}$ & $\begin{array}{c}1.529 \\
17.859 \\
3.352 \\
\end{array}$ \\
\hline $6 \mathrm{hr}$ & $\begin{array}{l}\text { Inlet } \\
\text { Midpoint } \\
\text { Outlet }\end{array}$ & $\begin{array}{c}299.112 \\
55.013 \\
41.340\end{array}$ & $\begin{array}{c}296.086 \\
65.060 \\
53.484 \\
\end{array}$ & $\begin{array}{c}297.599 \\
60.036 \\
47.412\end{array}$ & $\begin{array}{l}.139 \\
7.104 \\
8.587 \\
\end{array}$ \\
\hline Phase IV & Point & \multicolumn{4}{|c|}{ Gas Chromatogram Diesel Fuel Concentration, $\mathrm{mg} / \mathrm{L}$} \\
\hline HRT & & Run\#1 & Run\#2 & Average & Stdev \\
\hline $96 \mathrm{hr}$ & $\begin{array}{l}\text { Inlet } \\
\text { Midpoint } \\
\text { Outlet }\end{array}$ & $\begin{array}{l}101.310 \\
34.671 \\
22.572\end{array}$ & $\begin{array}{c}104.642 \\
30.568 \\
23.068 \\
\end{array}$ & $\begin{array}{c}102.976 \\
32.616 \\
22.820\end{array}$ & $\begin{array}{l}2.356 \\
2.905 \\
0.351\end{array}$ \\
\hline $72 \mathrm{hr}$ & $\begin{array}{l}\text { Inlet } \\
\text { Midpoint } \\
\text { Outlet }\end{array}$ & $\begin{array}{l}94.693 \\
68.362 \\
25.039\end{array}$ & $\begin{array}{l}92.632 \\
68.136 \\
24.442\end{array}$ & $\begin{array}{l}93.663 \\
68.249 \\
24.741\end{array}$ & $\begin{array}{l}1.458 \\
0.159 \\
0.423\end{array}$ \\
\hline $48 \mathrm{hr}$ & $\begin{array}{l}\text { Inlet } \\
\text { Midpoint } \\
\text { Outlet }\end{array}$ & $\begin{array}{l}95.221 \\
57.911 \\
24.221\end{array}$ & $\begin{array}{l}94.475 \\
56.131 \\
27.012\end{array}$ & $\begin{array}{l}94.848 \\
57.021 \\
25.617\end{array}$ & $\begin{array}{l}0.527 \\
1.258 \\
1.974\end{array}$ \\
\hline $24 \mathrm{hr}$ & $\begin{array}{l}\text { Inlet } \\
\text { Midpoint } \\
\text { Outlet }\end{array}$ & $\begin{array}{l}94.467 \\
64.663 \\
32.202\end{array}$ & $\begin{array}{l}97.716 \\
63.470 \\
33.401\end{array}$ & $\begin{array}{l}96.092 \\
64.067 \\
32.801\end{array}$ & $\begin{array}{l}2.298 \\
0.844 \\
0.848\end{array}$ \\
\hline $12 \mathrm{hr}$ & $\begin{array}{l}\text { Inlet } \\
\text { Midpoint } \\
\text { Outlet }\end{array}$ & $\begin{array}{l}95.636 \\
48.176 \\
33.865\end{array}$ & $\begin{array}{l}93.285 \\
42.146 \\
34.226\end{array}$ & $\begin{array}{l}94.460 \\
45.161 \\
34.046\end{array}$ & $\begin{array}{l}1.662 \\
4.264 \\
0.255\end{array}$ \\
\hline $6 \mathrm{hr}$ & $\begin{array}{l}\text { Inlet } \\
\text { Midpoint } \\
\text { Outlet }\end{array}$ & $\begin{array}{l}90.406 \\
36.544 \\
35.733\end{array}$ & $\begin{array}{l}92.249 \\
40.222 \\
33.862\end{array}$ & $\begin{array}{l}91.328 \\
38.383 \\
34.797\end{array}$ & $\begin{array}{l}1.303 \\
2.601 \\
1.323\end{array}$ \\
\hline
\end{tabular}




\section{APPENDIX E- Gas Chromatograms for Anaerobic Adsorption Test}

Figure E 1. Gas Chromatogram - Anaerobic Adsorption Isotherm Test, Experimental Run 1 Trial 1

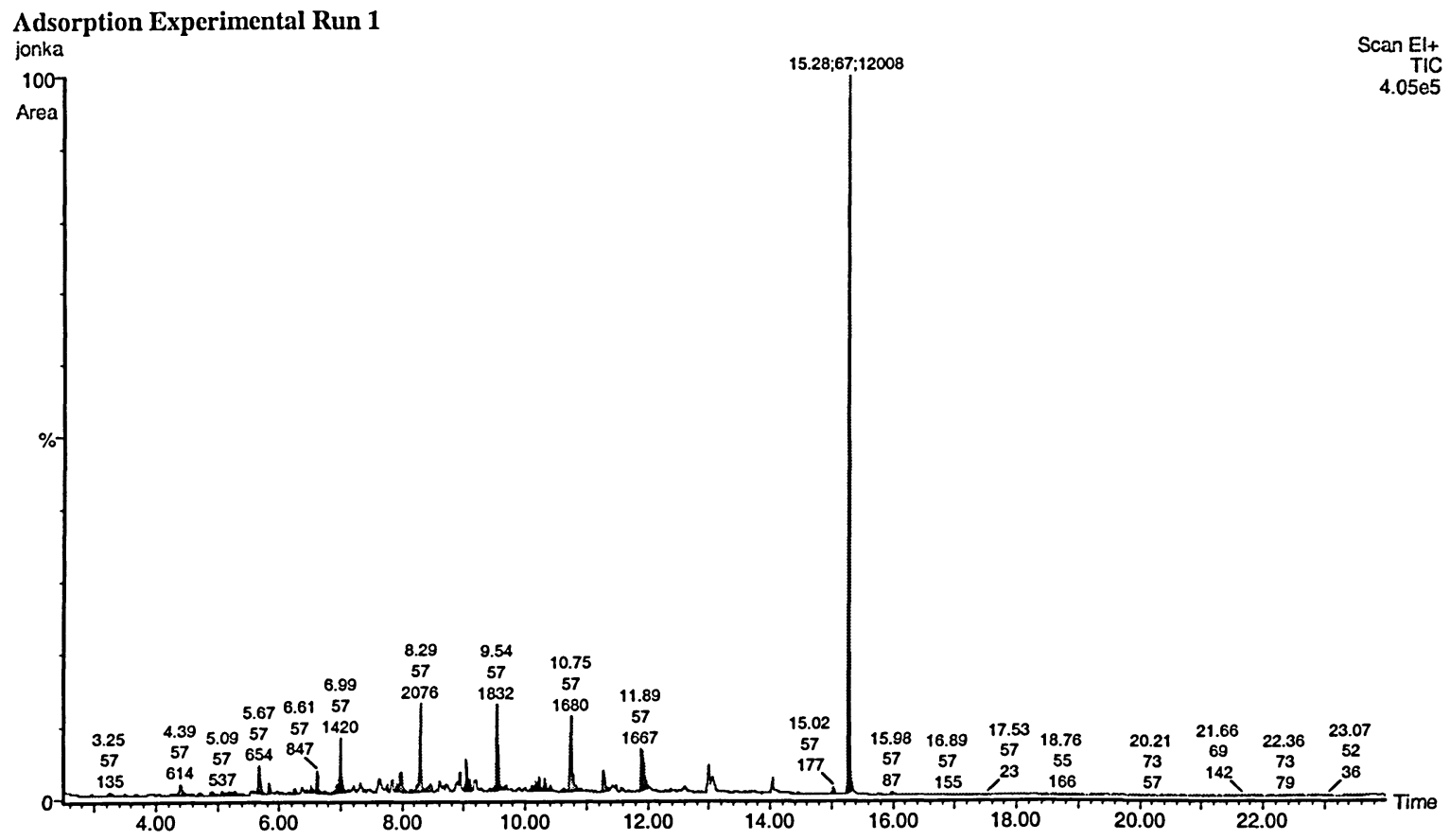

Figure E 2. Gas Chromatogram - Anaerobic Adsorption Isotherm Test, Experimental Run 1 , Trial 2

Adsorption Experimental Run 1

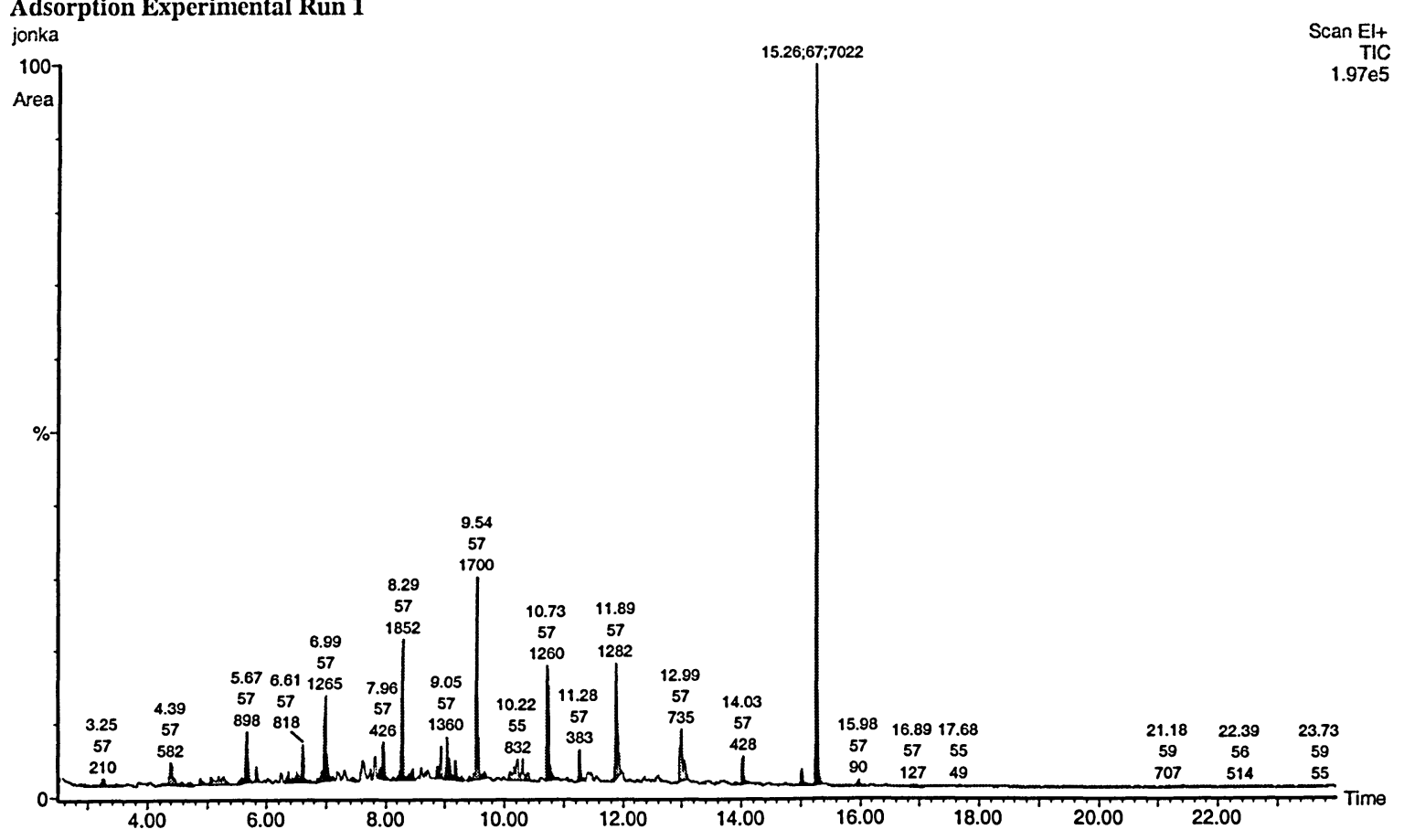


Figure E 3. Gas Chromatogram - Anaerobic Adsorption Isotherm Test, Experimental Run 2 Trial 1

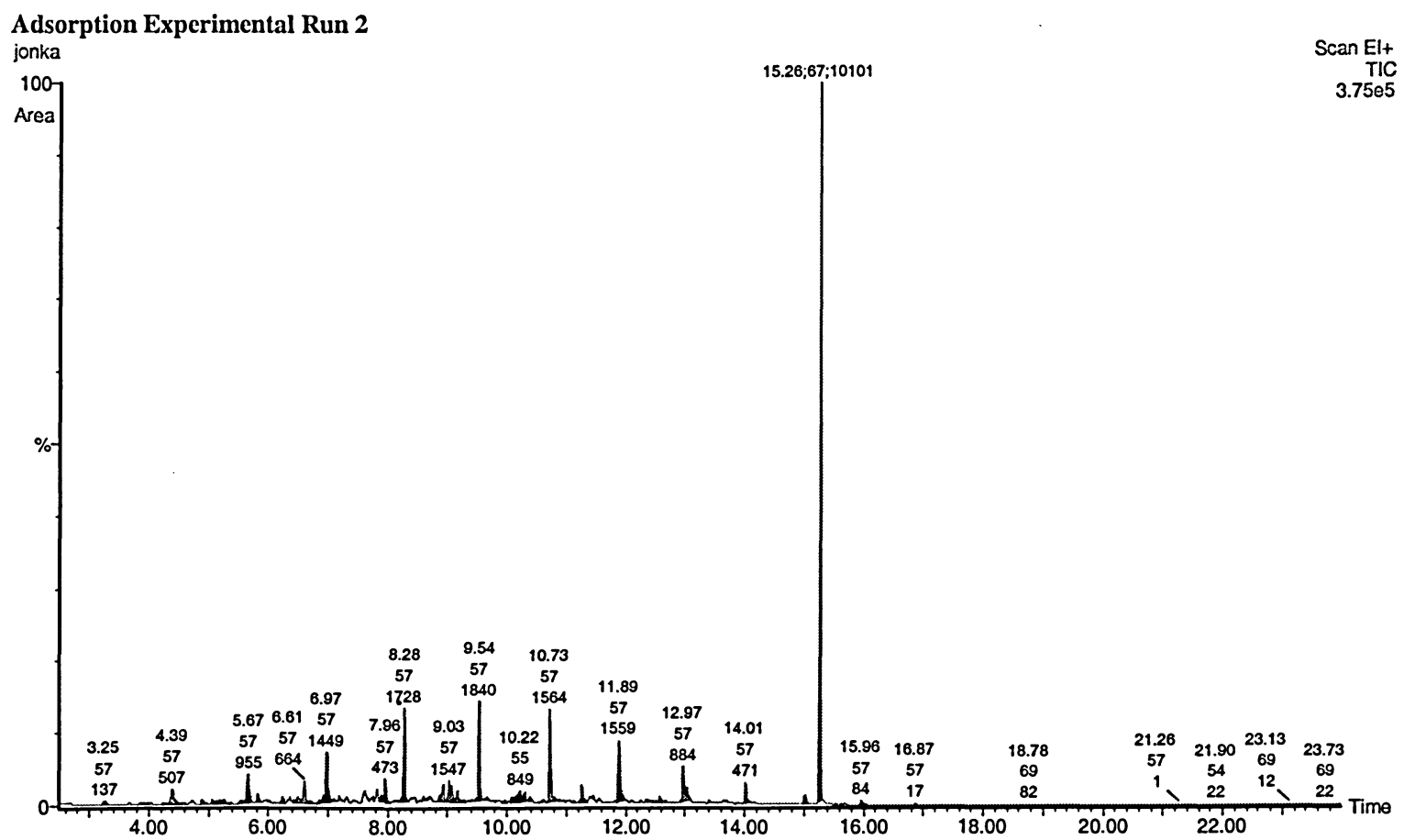

Figure E 4. Gas Chromatogram - Anaerobic Adsorption Isotherm Test, Experimental Run 2, Trial 2

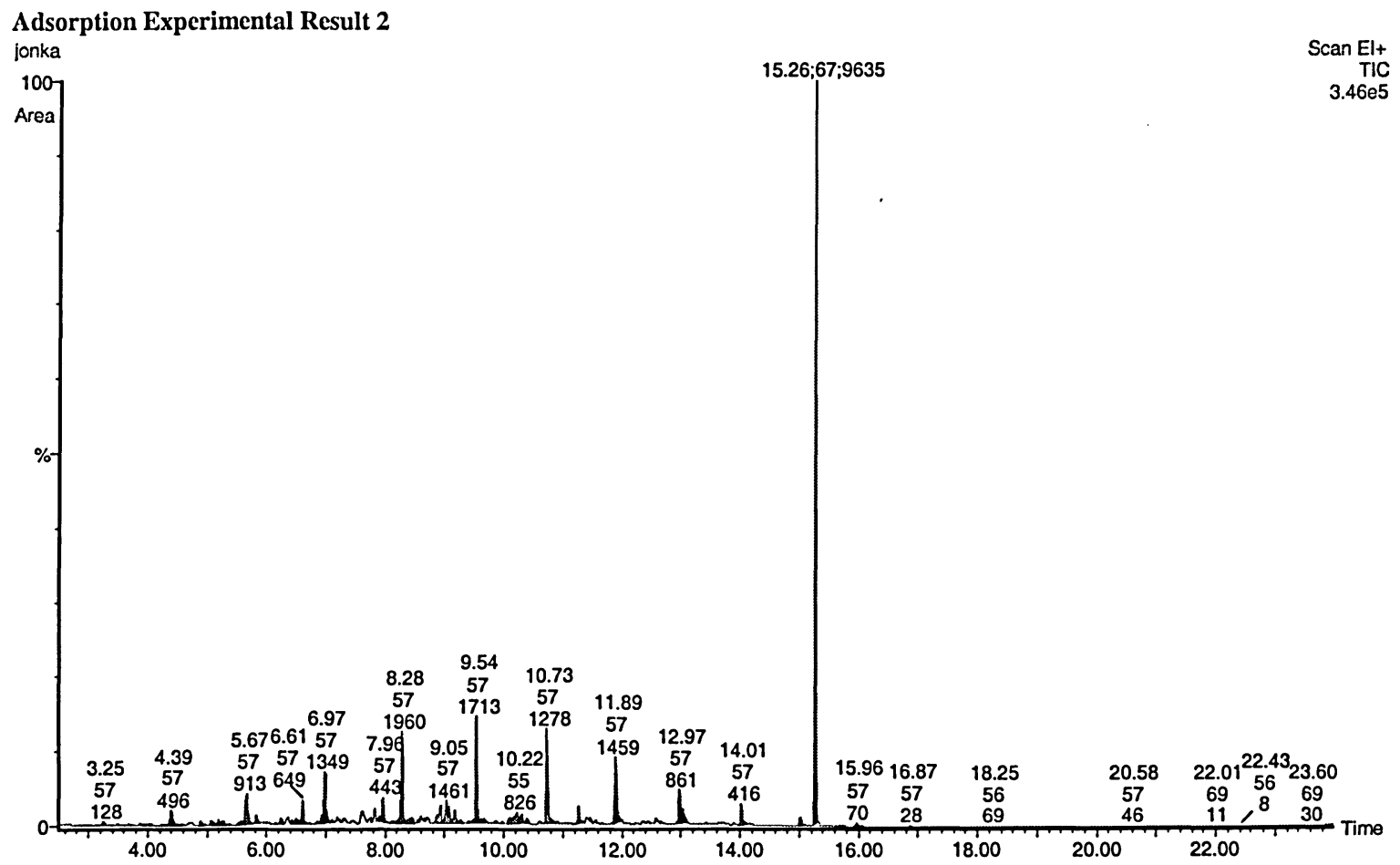


Figure E 5. Gas Chromatogram - Anaerobic Adsorption Isotherm Test, Experimental

\section{Run 3 Trial 1}

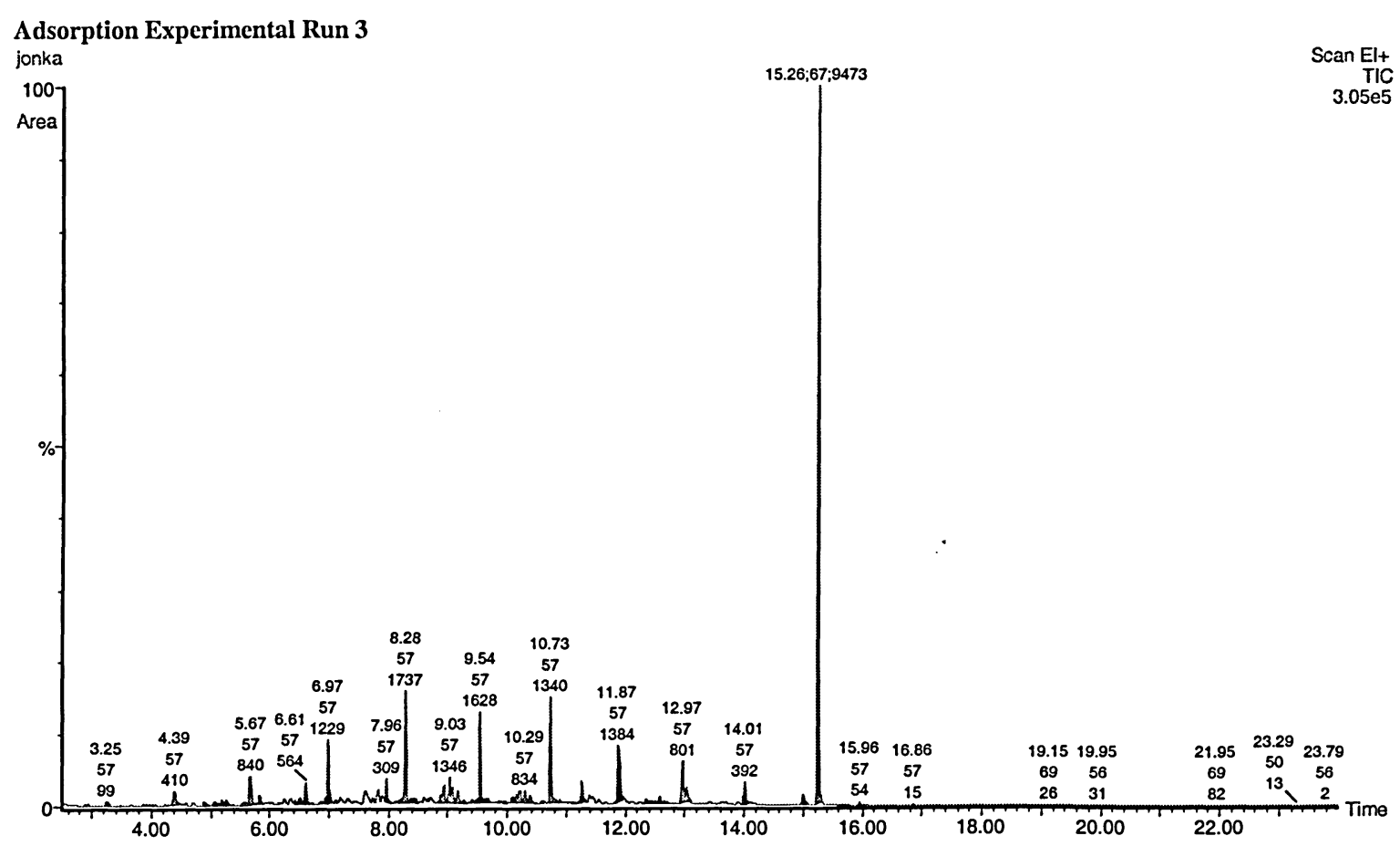

Figure E 6. Gas Chromatogram - Anaerobic Adsorption Isotherm Test, Experimental

Run 3, Trial 2

Adsorption Experimental Run 3

jonka

100
Area

$15.26 ; 67 ; 8300$

Scan El+ 3.89e5

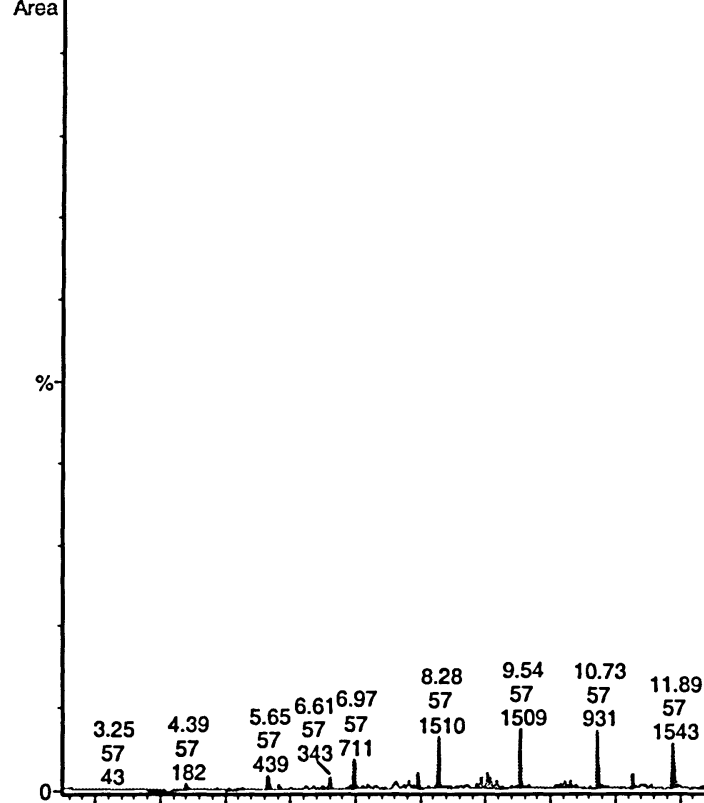

$12.97 \quad 14.01$

4.00

6.00

10.00

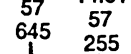

15.9616 .8717 .75

$\begin{array}{lll}57 & 57 & 57\end{array}$

\begin{tabular}{lll}
57 & 57 & 57 \\
87 & 65 & 12 \\
\hline
\end{tabular}

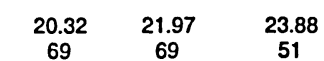

.00

14.00

16.00 
Figure E 7. Gas Chromatogram - Experimental Run 4 Anaerobic Adsorption Isotherm Test, Trial 1

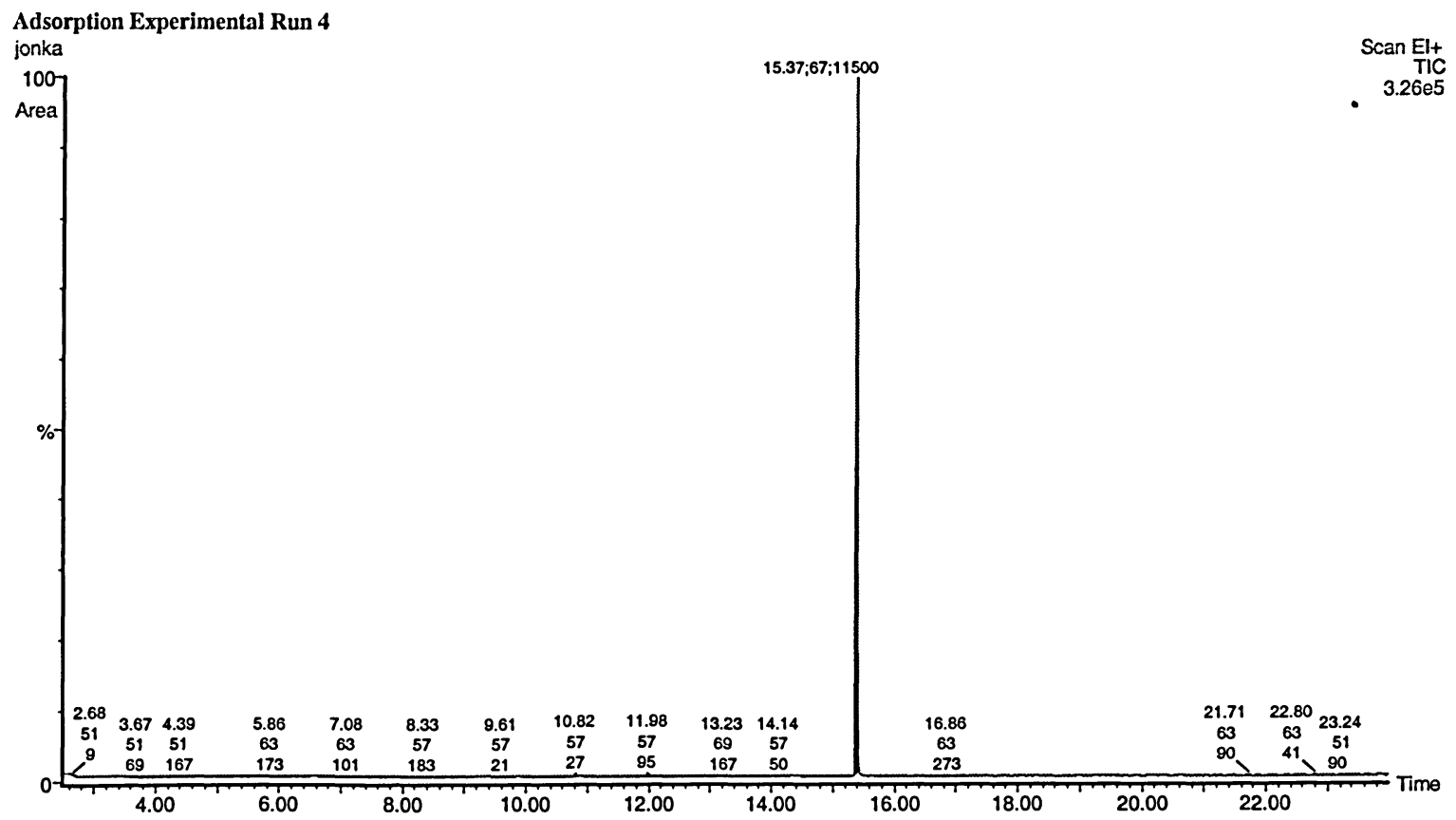

Figure E 8. Gas Chromatogram - Experimental Run 4 Anaerobic Adsorption Isotherm Test,

\section{Trial 2}

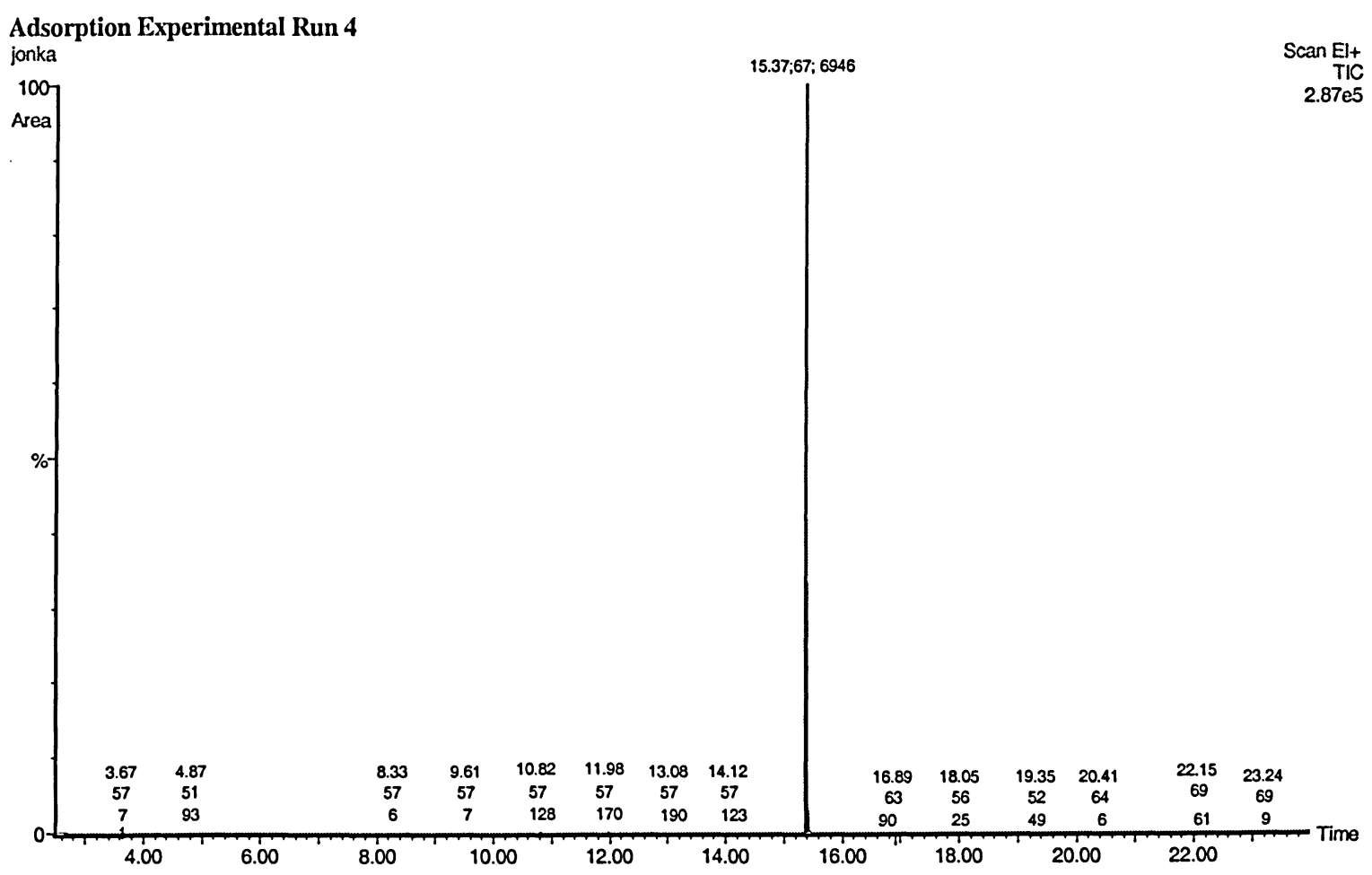


Figure E 9. Gas Chromatogram - Anaerobic Adsorption Isotherm Test, Experimental Run 5 Trial 1

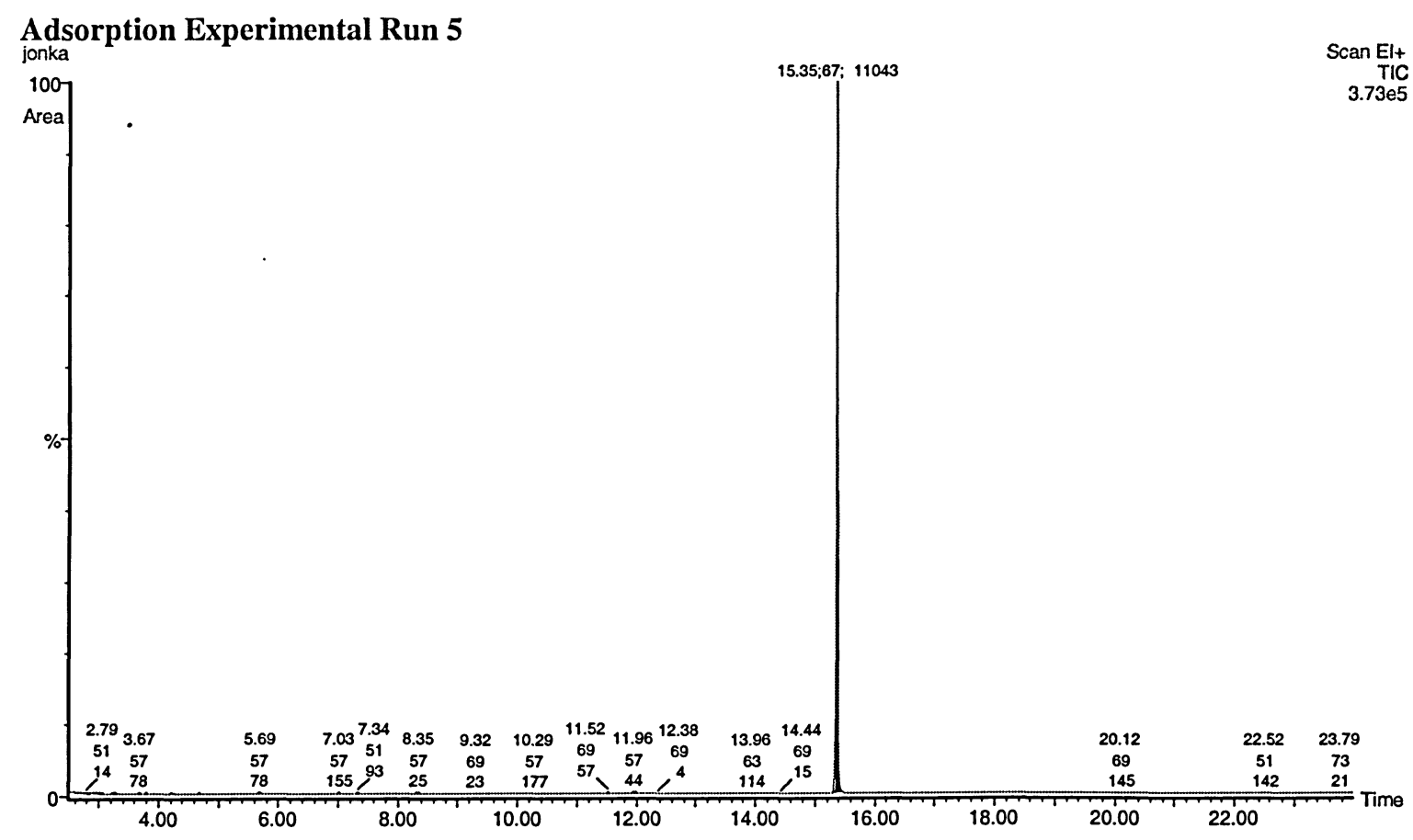

Figure E 10. Gas Chromatogram - Anaerobic Adsorption Isotherm Test, Experimental Run

\section{Trial 2}

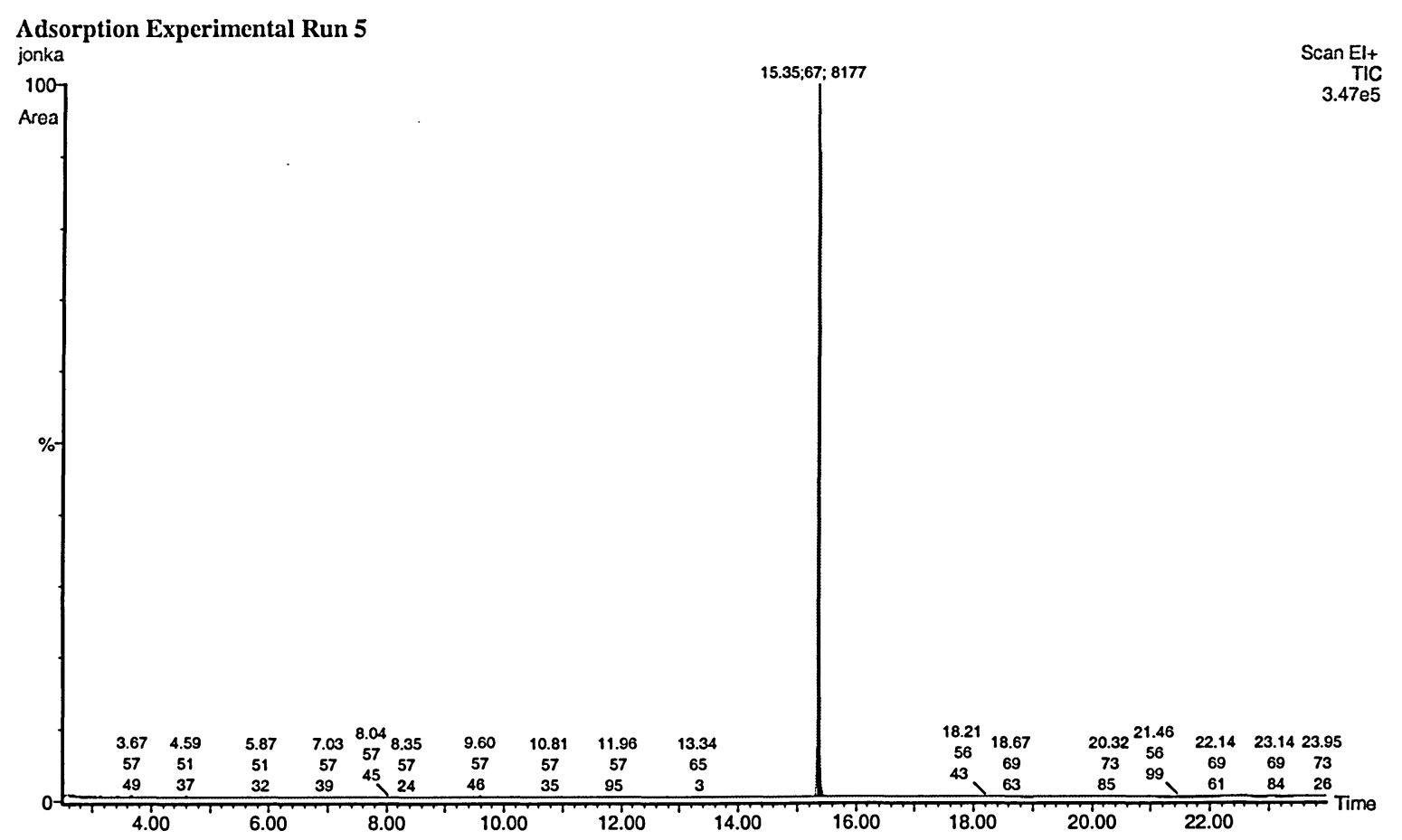


Figure E 11. Gas Chromatogram - Anaerobic Adsorption Isotherm Test, Experimental Run 6 Trial 1

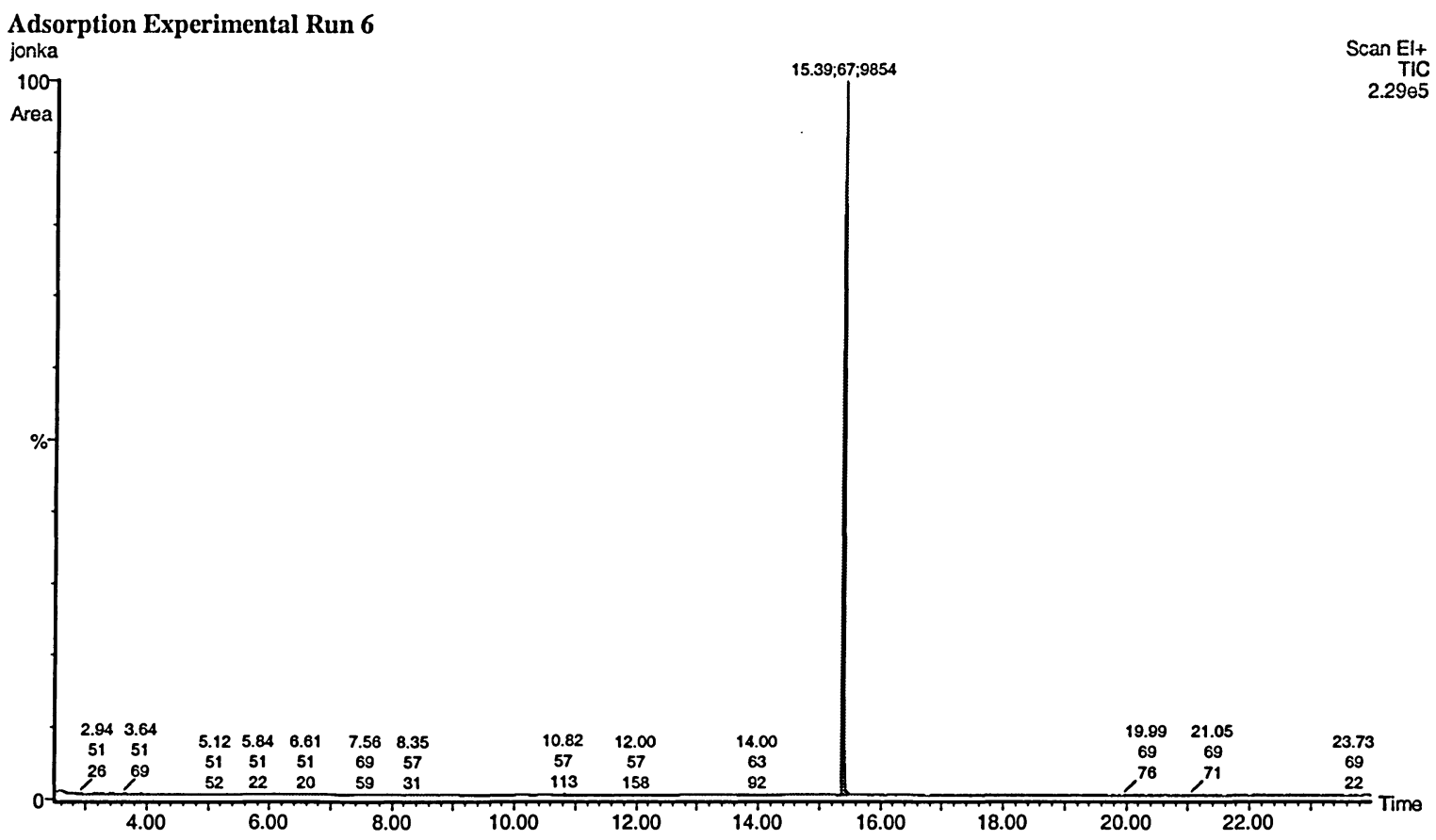

Figure E 12. Gas Chromatogram - Anaerobic Adsorption Isotherm Test, Experimental Run 6 Trial 2

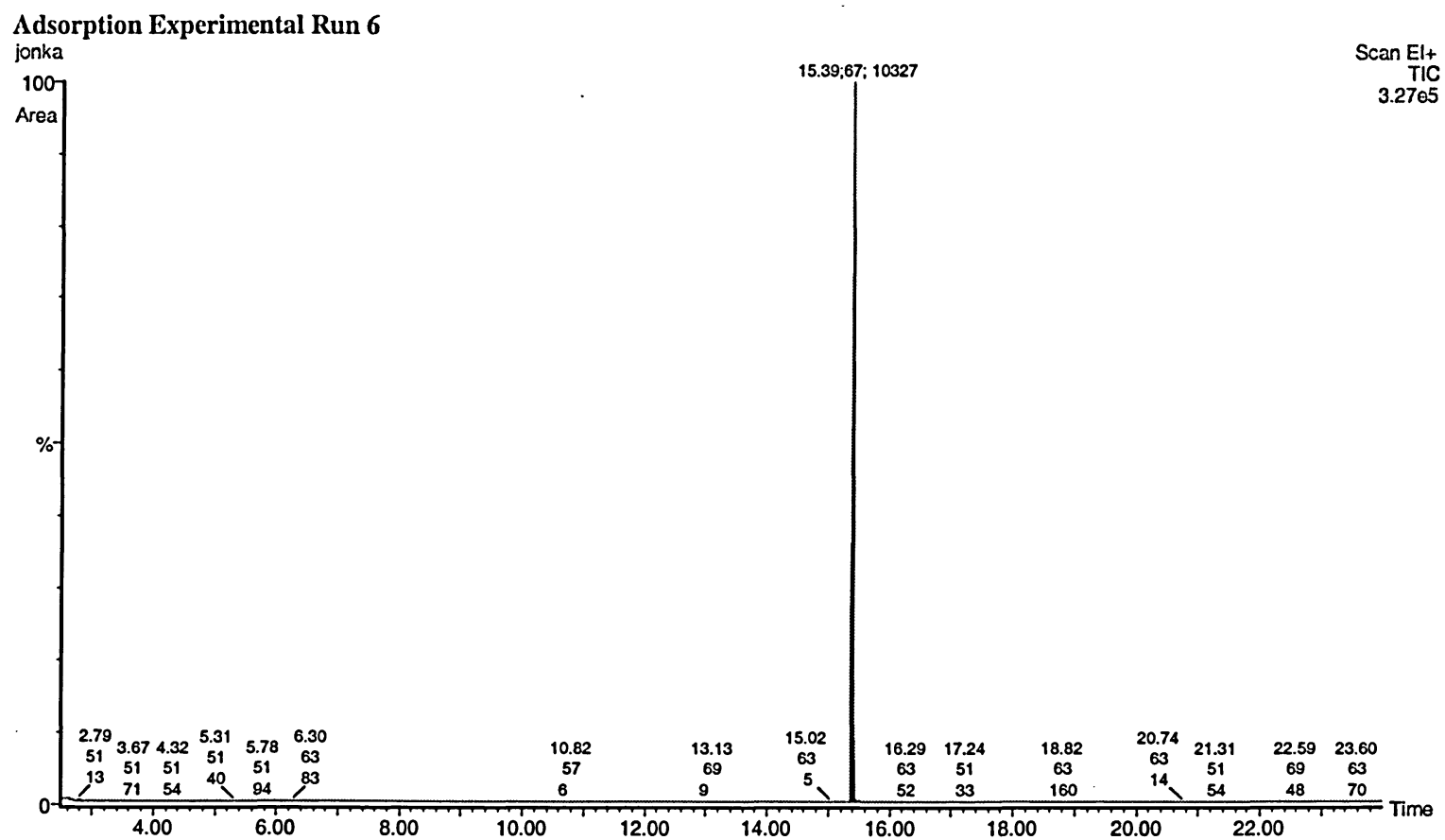


Figure E 13. Gas Chromatogram - Anaerobic Adsorption Isotherm Test, Experimental Run 7 Trial 1

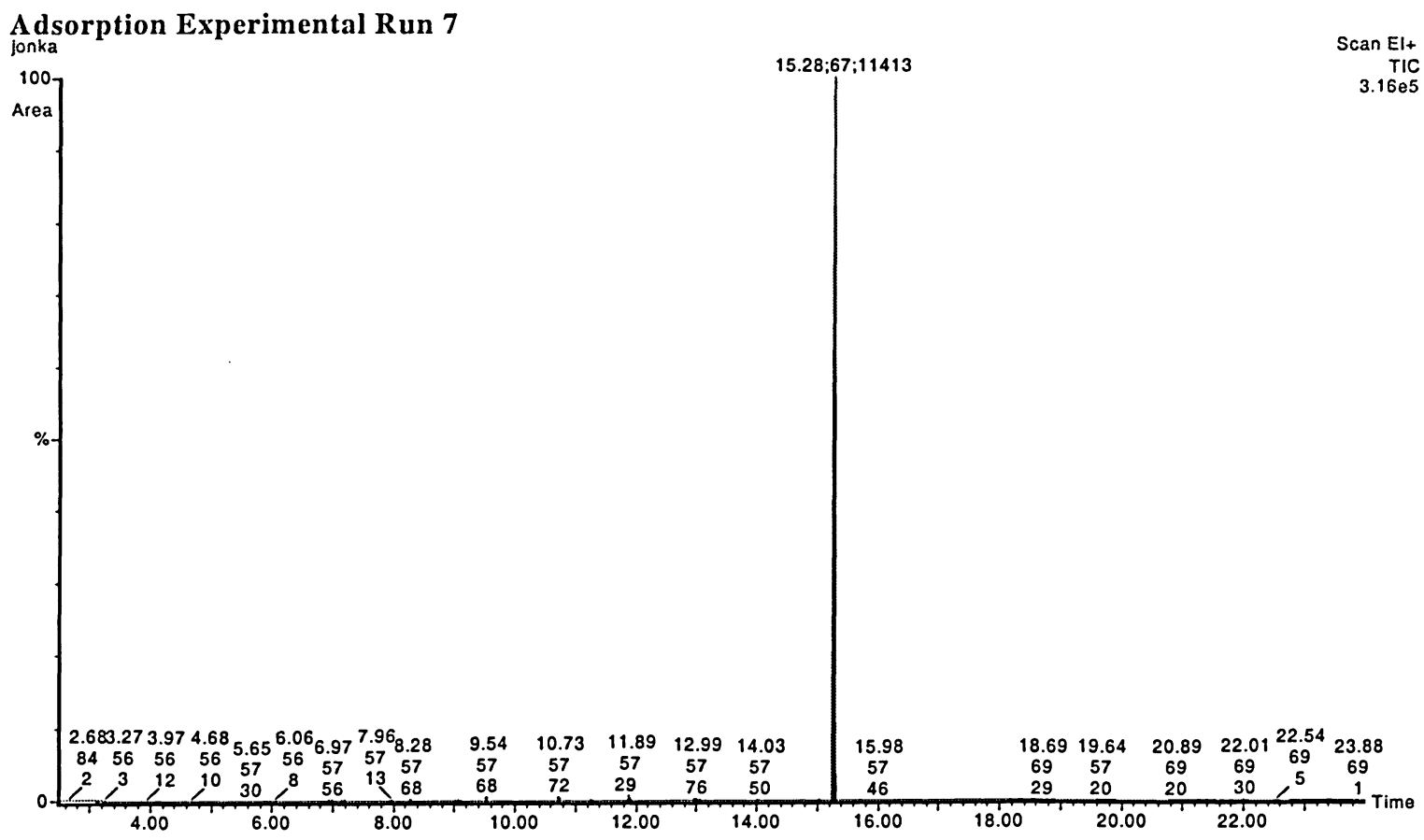

Figure E 14. Gas Chromatogram - Anaerobic Adsorption Isotherm Test, Experimental

Run 7 Trial 2

\section{$\underset{\substack{\text { Aonka } \\ \text { for }}}{\text { Adion Experimental } 7}$}

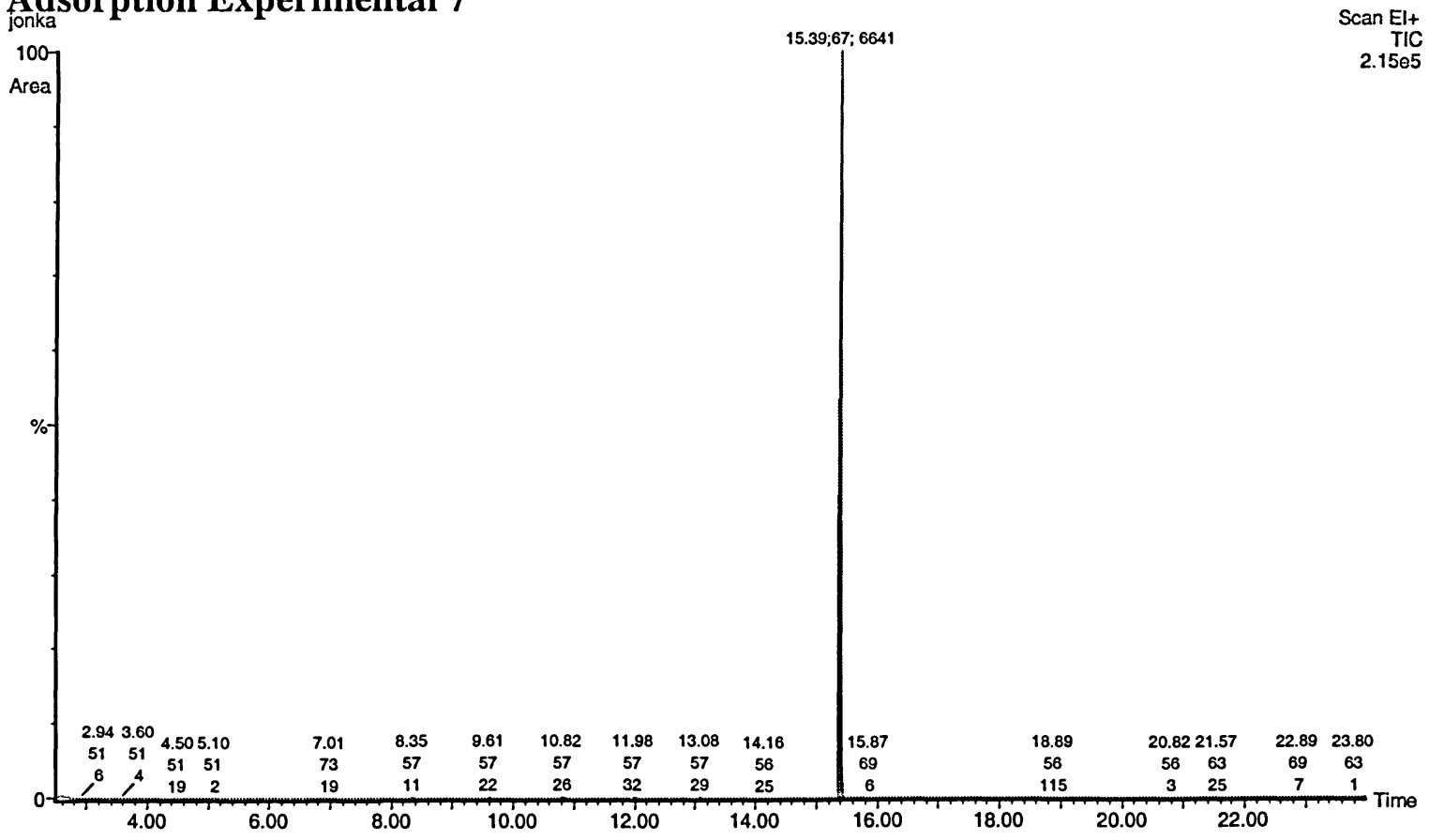


Figure E 15. Gas Chromatogram - Anaerobic Adsorption Isotherm Test, Experimental

\section{Run 8 Trial 1}

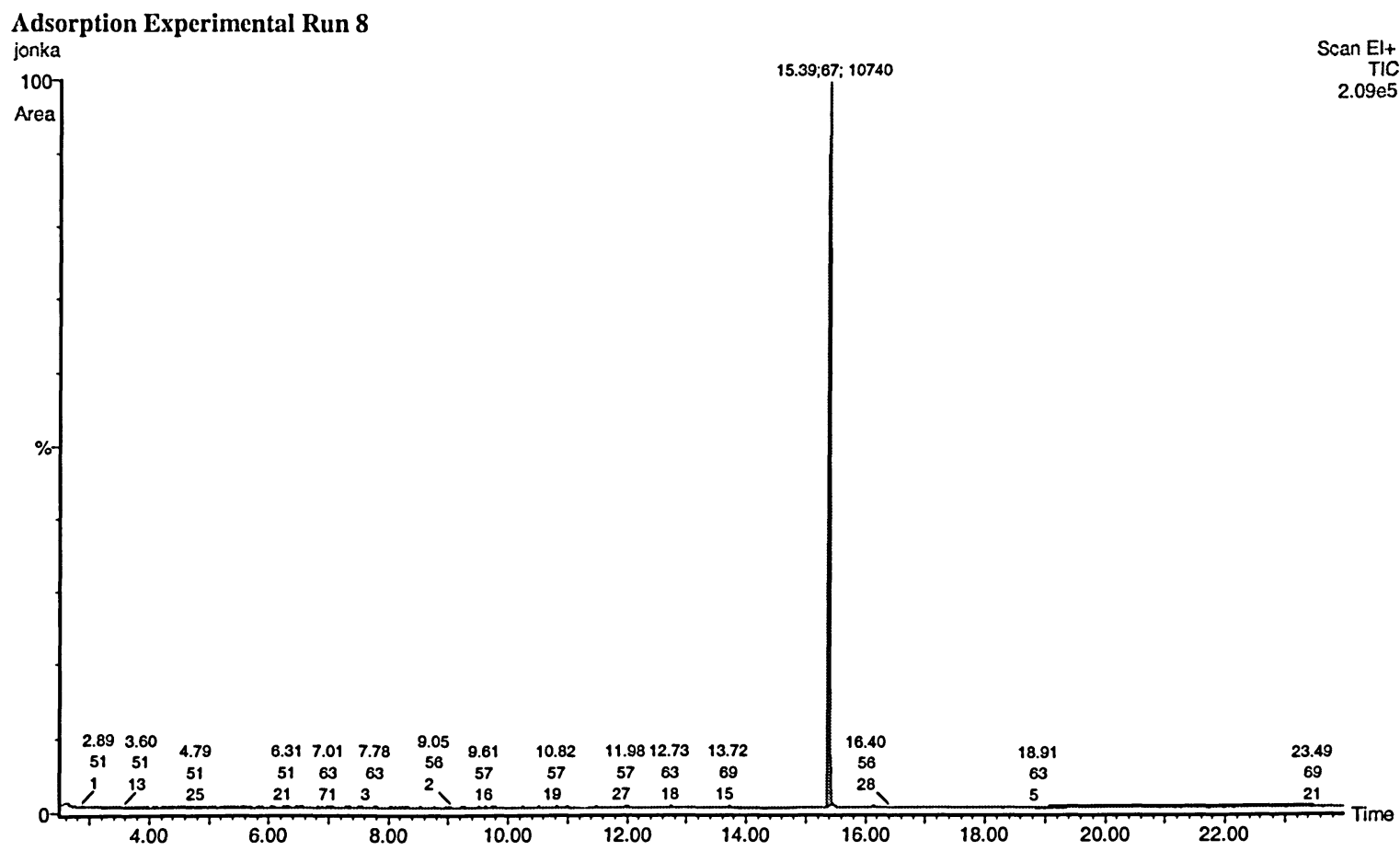

Figure E 16. Gas Chromatogram - Anaerobic Adsorption Isotherm Test, Experimental Run 8, Trial 2

Adsorption Experimental Run 8

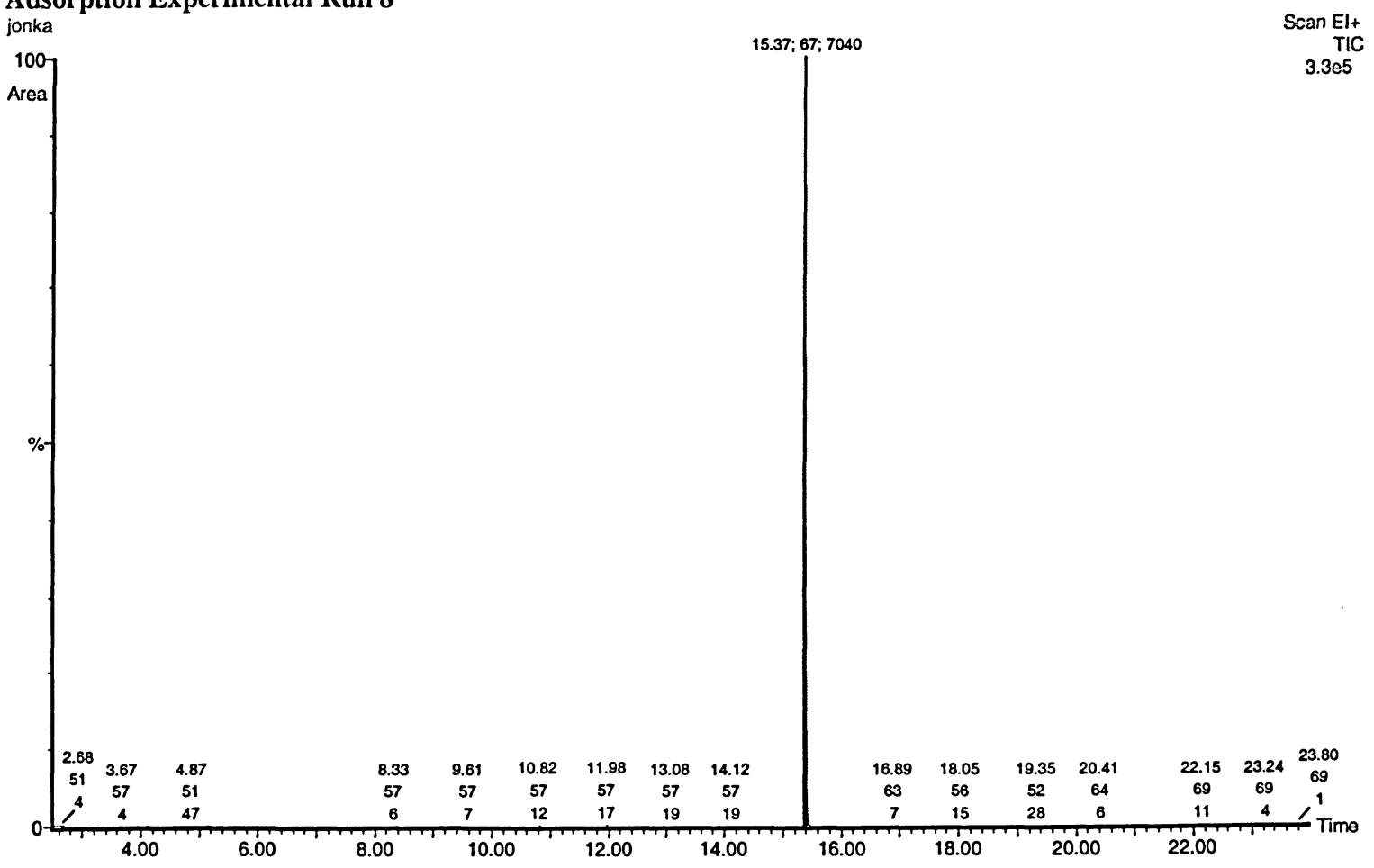

